Historic, archived document

Do not assume content reflects current scientific knowledge, policies, or practices. 


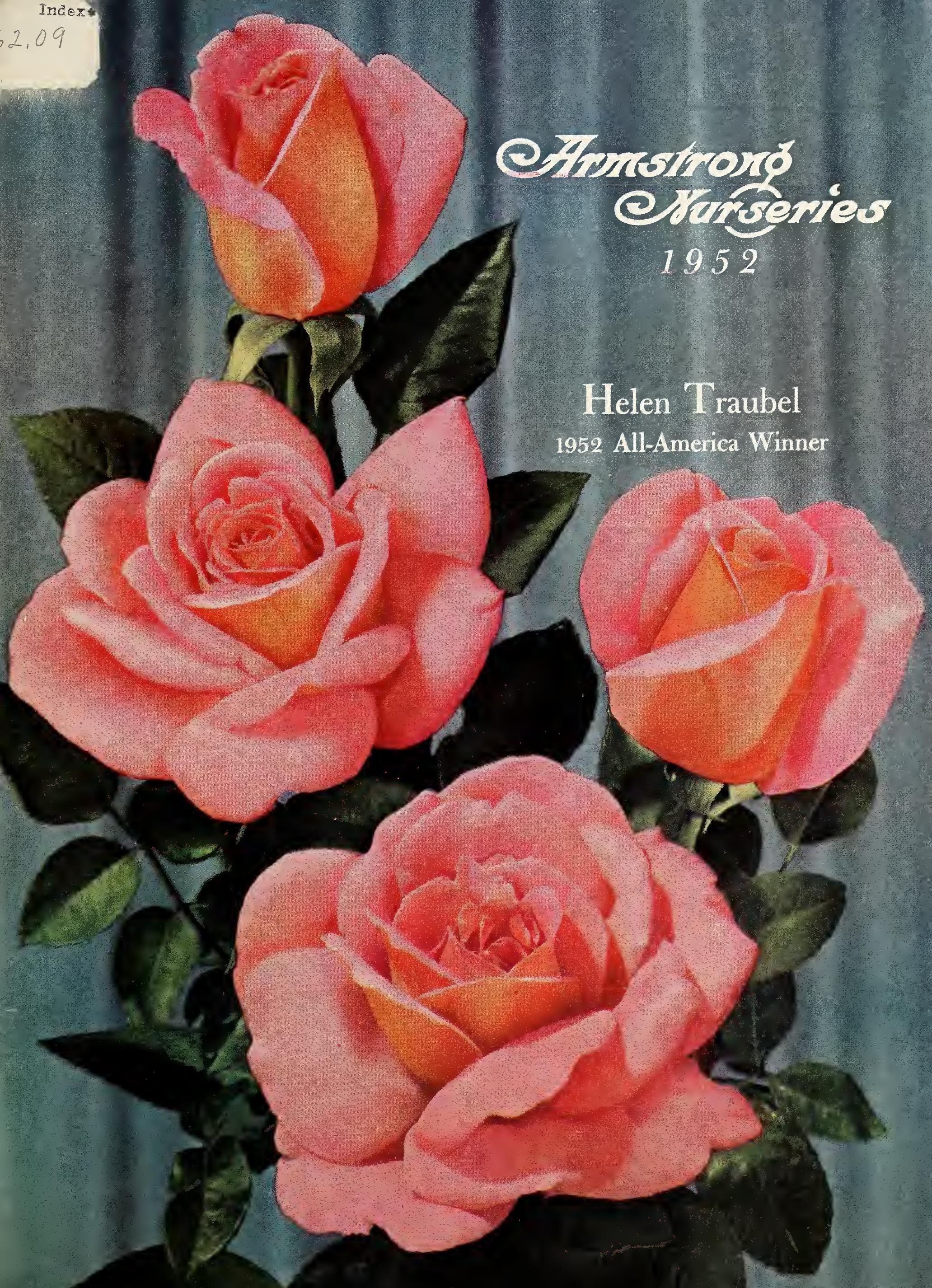




\section{Five Big Salesyards \\ in Southern California} gladly advise you on what to plant, where, when, and how to plant it. With the exception of New Year's Day, Easter Sunday, Memorial Day, July 4th, Labor Day, Thanksgiving and Christmas Day, all yards are open every day including Sunday.

Please address all mail orders and correspondence to the Ontario office.

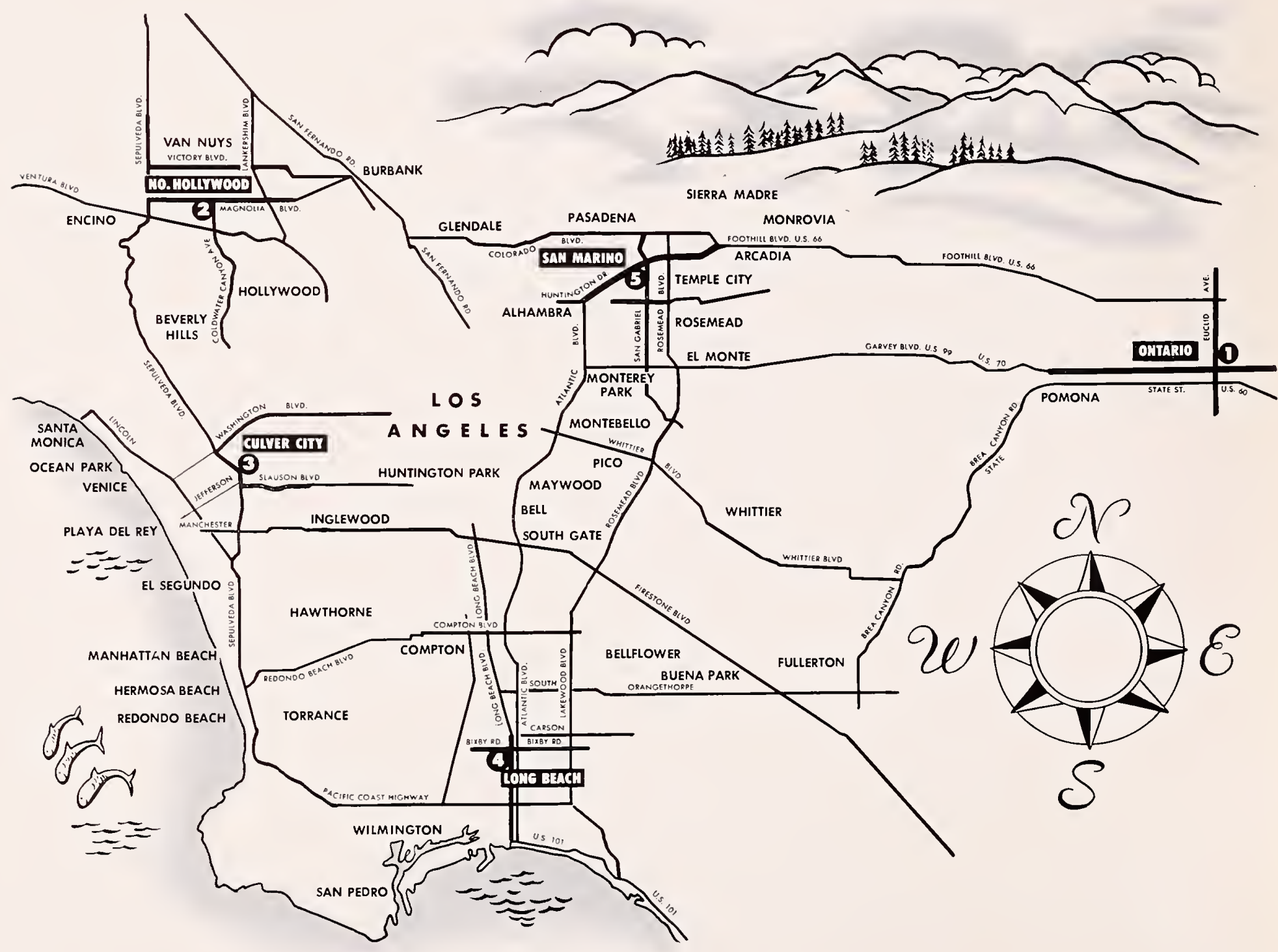

\section{Ontario 408 North Euclid Avenue}

On famous Euclid Avenue, four blocks north of Highway 99.

Telephone: Ontario 627-61

3 Culver City 4440 Sepulveda Blvd.

On Sepulveda Blvd., just five blocks south of Washington Blvd.

Telephone: VErmont 82-665 


\section{Armstrong Quality Plants Are Easy to Get - No Matter Where You Live}

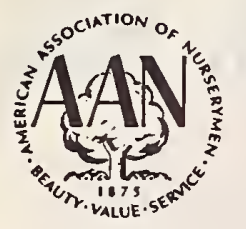

If you live too far away to visit one of our salesyards mail your order to us and we will ship it by the quickest and most economical means. We have no agents and you can get genuine Armstrong products only through our five Southern California salesyards or by mailing your order to Armstrong Nurseries at Ontario, California.

Member of the American Association of Nurserymen.

Member of the California Association of Nurserymen.

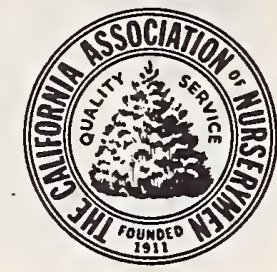

\section{Years Old}

In 1952 the Armstrong Nurseries will celebrate its 62nd birthday. Naturally, we are very proud of the 61 successful years we have enjoyed. From your letters and from your personal remarks, we know that we have gained so many new friends only because for the entire 61 years we have been producing plants and trees which are the best it is possible to grow. Whether you are a new customer or an old friend, we think we can serve you best and merit your continued confidence by making sure that the famous Armstrong quality is a part of every plant that goes into your garden.

\section{Truck Deliveries}

If you live within 60 miles of Ontario and near an easily accessible highway, we will gladly deliver your order right to your door by one of our covered trucks. The charge for this service is only 50c. Sometimes small orders which are light in weight can be delivered more rapidly and economically by mail or express so we reserve the right to determine the method of shipment.

To more distant points on main highways, such as San Diego, Santa Barbara, and Palm Springs, we deliver as often as we have full loads. The minimum delivery charge to such points is $\$ 1.25$ for orders weighing less than 200 pounds and $75 \mathrm{C}$ per hundred pounds additional on larger orders.

Orders placed in person at any of our five Southern California salesyards will be delivered free of charge in the area adjacent to the salesyard.

\section{Mail, Express E Freight}

Our expęrt packing assures safe arrival of your goods no matter which form of common carrier is used for delivery.

\section{Bare Root Shipments Prepaid}

We prepay the transportation costs on all orders consisting entirely of bare root plants, except tree roses, to any point in continental U.S. whether it be shipped by mail, express, or freight.

\section{Packing Charges}

On all plants which must be shipped with soil (balled or in containers), we make a charge of $10 \%$ for packing. Camellia plants are the only exception. If your order is mixed, i.e., if it includes both container and bare root plants, the packing charge to send with your remittance is just $10 \%$ of the value of the plants which are balled or in containers. You include no packing charge for bare root material, such as roses, deciduous fruit trees, berries, grapes, nor for deciduous trees and shrubs. Include no packing charge for camellias. Include no packing charge for plants of any type to be delivered by our trucks.

\section{Plants in Containers or Balled-Shipped Collect}

All plant material, balled or in containers (including camellias), will be shipped by express or freight collect. You pay the delivery man for transportation charges when the shipment is delivered.

\section{Export Shipments}

We have specialized in the export of our products for many years and there are now Armstrong plants growing successfully in all parts of the world. Our skilled shipping staff is informed on all regulations and can furnish all documents necessary. Write us air mail for speedier service.

\section{Terms}

Cash with order. Send your personal check, post office money order, postal note, express or bank money order. No orders sent C. O. D. All California purchasers whose orders are being shipped to California points will please add the sales tax of $3 \%$.

\section{Inspection}

We guarantee all shipments to pass inspection wherever shipped. In many California counties plants must be inspected upon arrival. Look for directions on inspection tag attached to order. Phone your County Agricultural Commissioner for further information.

\section{Plant Losses}

Our reputation depends upon the results you have, and we make every effort to get the plants to you in excellent condition. Planting instructions based on our experience are included with every shipment. Plants are subject to the whims of nature and man and no one can guarantee that a certain one will thrive. When our instructions are followed, however, only very rarely should you lose a plant. Tell us immediately if any shipment is any way unsatisfactory upon arrival. It is our desire to make a fair adjustment and help you get the best results possible.

\section{Price Changes}

We hope to be able to maintain the prices given in this catalog throughout the sales season for which it is issued. However, unforeseen conditions sometimes make price changes necessary and we reserve the right to make price changes at any time without notice.

\section{Note:}

Armstrong Nurseries will exercise care to have merchandise true to name. Provided it is expressly understood that all orders are accepted on the condition precedent that it makes no warranty, express or implied, as to description, quality, productiveness, crops, or any other matter whatsoever; that its liability in every instance whatso. ever is limited to the purchase price; that orders shall be void should delivery be prevented or injury befall the stock from flood, drought, frost, or other causes beyond its control and orders travel at risk of purchaser.

\section{Express Rates}

Miles from Ontario
$100 \quad 200 \quad 400 \quad 600 \quad 1,000 \quad 2,0003,000$

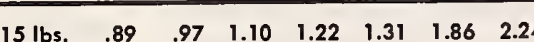

$\begin{array}{lllllllll}20 & \text { lbs. } & .98 & 1.08 & 1.25 & 1.41 & 1.55 & 2.27 & 2.76\end{array}$

$\begin{array}{lllllllll}25 & \text { lbs. } & 1.07 & 1.19 & 1.40 & 1.61 & 1.77 & 2.68 & 3.29\end{array}$

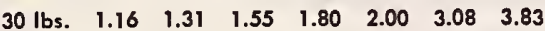

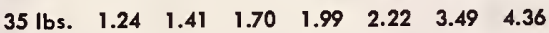

$\begin{array}{lllllllll}40 & \text { lbs. } & 1.33 & 1.52 & 1.85 & 2.18 & 2.45 & 3.90 & 4.89\end{array}$

$\begin{array}{lllllllll}45 & \text { lbs. } & 1.41 & 1.64 & 2.00 & 2.38 & 2.67 & 4.31 & 5.42\end{array}$

$\begin{array}{llllllll}50 & \text { lbs. } \quad 1.50 & 1.75 & 2.16 & 2.57 & 2.90 & 4.72 & 5.96\end{array}$

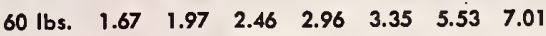

$\begin{array}{lllllllll}70 & \text { lbs. } & 1.84 & 2.19 & 2.77 & 3.35 & 3.80 & 6.35 & 8.08\end{array}$

$\begin{array}{llllllll}80 & \text { lbs. } \quad 2.01 & 2.41 & 3.07 & 3.73 & 4.25 & 7.16 & 9.14\end{array}$

$\begin{array}{lllllllll}90 & \text { lbs. } & 2.18 & 2.63 & 3.38 & 4.12 & 4.71 & 7.97 & 10.20\end{array}$

$\begin{array}{llllllll}100 & \text { lbs. } 2.36 & 2.85 & 3.68 & 4.50 & 5.16 & 8.79 & 11.27\end{array}$

Rates approximate only. Subject to change at any time without notice.

\section{Freight Rates}

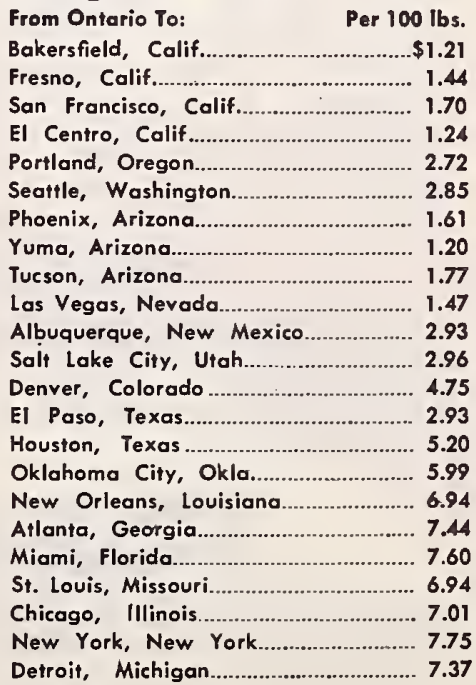




\section{Armstrong Roses}

No Matter Where You Live-

\section{You Can Enjoy Better Results With Them}

From over 50,000 rose varieties in the world today it is our continuous aim to test, judge, and carefully select the best for color, form, and garden performance. Yes, we even go a step beyond that for some of the most outstanding new roses in the world have been created right here in the Armstrong Research Department. Even for good varieties to give you outstanding performance, it is necessary that the plants be carefully grown-there is the difference in Armstrong roses. Over 60 years of experience, perfect growing conditions, and the aim to produce the best plants grown anywhere, is the combination which makes for better roses in your garden.

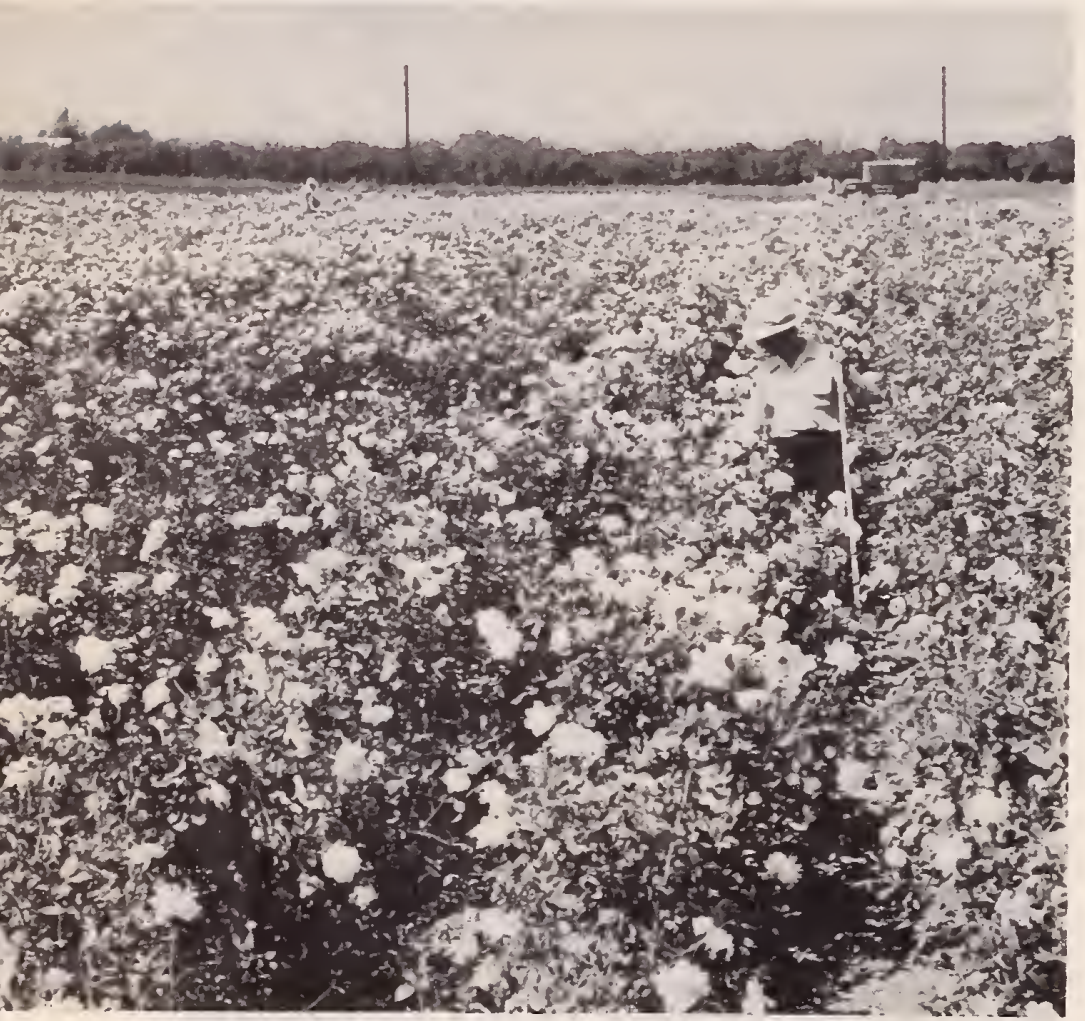

Planting Time

No matter where you live, your bare root roses will be shipped at the most favorable time for planting in your area, and the approximate shipping time will be noted on the invoice which you will receive acknowledging your order. Generally speaking, planters in Arizona Nevada, and desert sections of the Pacific Southwest should plant roses in December and January. Along the Pacific Coast, bare root plants are usually set out in January, February, or March. To the east and midwest they may be shipped as late as April or May. Blooming roses in containers are available at our five Southern California salesyards during the summer and fall months. Prices on container roses are slightly higher than for bare root plants listed in this catalog.

\section{Our Guarantee}

If you follow the simple steps outlined in the Planting Guide which you will receive free with every shipment of Armstrong Roses, and providing weather is not abnormal or there are no damaging factors beyond our control, we guarantee every Armstrong rose to grow and bloom in your garden.

\section{Order 3 or More of a Variety and Save}

You can save substantially by ordering three or more roses of the same variety. Similar savings are realized when you purchase any of the collections listed on the opposite page.

\section{These Are the Plants for You}

The picture at the left shows some of the plants we will be delivering in late 1951 and early 1952. At the time this photograph was taken, the plants still had several months to grow and at digging time they'll be still larger! When you plant them in your garden these big, husky, well-rooted bushes will start faster and bloom more quickly.

\section{Armstrong Creations They've Won More All-America Awards Than the Roses of Any Other Rose Breeder in the World}

In no other competitive trials are the standards of evaluation so exacting as in the selection of All-America Roses. To have had more winners than anyone else in the world simply means that our standards for Armstrong Roses are higher. Not necessarily just a new rose, but a rose better than existing kinds is the goal for which our Research Department aims constantly. Know how? Sure we have it, but it takes a lot of hard work, years of patient observation, and selection after selection must be made before we can offer you a rose good enough to say of it, "Introduced by Armstrong Nurseries."

\section{They Cost No More}

With the exception of tree roses, all bare root rose plants sent by mail, express or freight to any point in the United States or its possessions are shipped at our expense. You pay nothing in addition to the catalog price of the roses you order except the sales tax of $3 \%$ if you live in California. We reserve the right to choose the method of shipment.

\section{Everblooming}

Without exception the bush roses listed in our catalog are of the so-called "everblooming" kinds. Both the Hybrid Teas and the Floribundas bloom continuously throughout the growing season. Seldom a day will pass in the late spring, summer, or fall when you cannot cut buds and flowers from these kinds.

\section{Planting Instructions}

With every shipment of Armstrong Roses you will receive complete planting instructions. You are almost certain to be successful with your rose growing if you will follow the few simple rules covering planting and care.

\section{Roses in Containers}

Throughout the late spring, summer, and fall, we can supply many of these roses, blooming in 5-gallon containers at prices somewhat increased over those in this catalog. Because of weight and bulkiness it is not practical to ship them (except locally) but you will find them on display in any of our five Southern California salesyards. 


\section{Special Anmstrong}

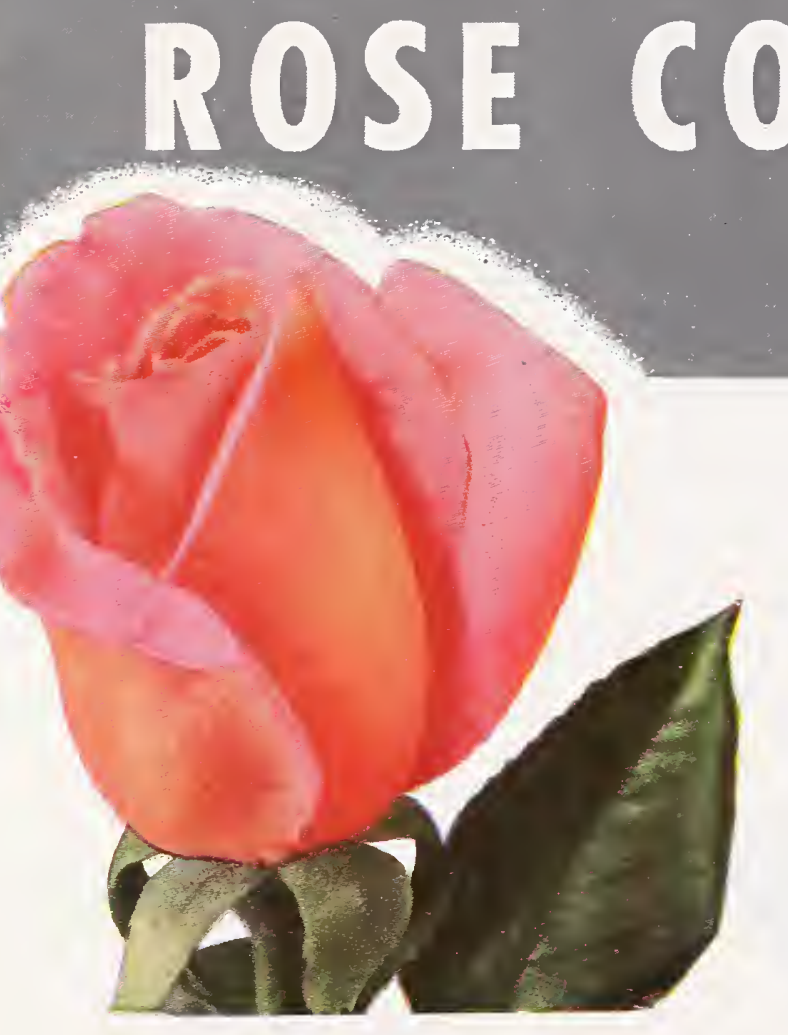

Helen Traubel

THE FAMOUS ARMSTRONG "BIG 10"

"A Perfect Rose Garden," 10 outstanding varieties carefully chosen for color, form and garden performance. See page 23 .

All Ten for

$\$ 1725$

\section{THE ALL-ARMSTRONG FIVE}

If you have room for only five plants, you could not make a better choice than the five Armstrong intro ductions included in this offer. See page 22 .

\section{THE THRIFTY SIX}

A collection of six really fine roses at an unusually low price. See page 17 for complete details.

Bravo- the reddest red rose

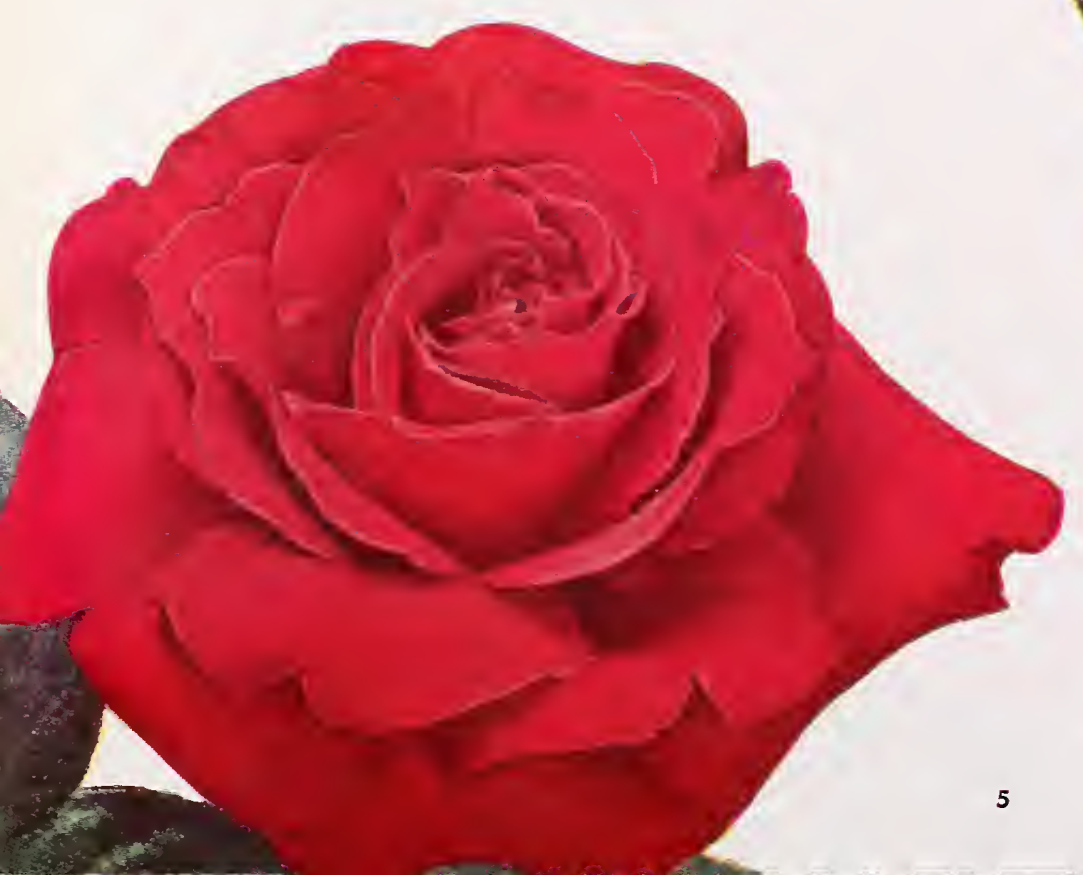

$\$ 860$

All Six for

$\$ 6^{25}$

\section{Collections Featuring "The Rose on the Cover" Helen Traubel} SHOW TIME COLLECTION

Helen Traubel. Apricot-pink. See page 6.

Bravo. Brilliant red. See page 11.

All Three for

Bravo. Brilliant red. See page 11.

$\$ 640$

\section{JACKPOT COLLECTION}

(Purchased singly would cost \$7.25.)

Helen Traubel. Apricot-pink. See page 6.

Charlotte Armstrong. Red to cerise. See page 10

Sutter's Gold. Fragrant yellow. See page

\section{ALL-AMERICA COLLECTION}

Five leading winners of All-America Awards:

Charlotie Armstrong, Helen Traubel, Nocturne,

Peace, and Sutter's Gold. These are the "cream

of the world's newer roses." See page 8.

All Five for

\section{THE '52 COLLECTION}

$\$ 970$

The two great new Armstrong rose introductions for 1952, Helen Traubel and Chief Seattle.

Please do not ask for variety substitutions.

Sutter's Gold-m the outstanding rose introduction for 1950 


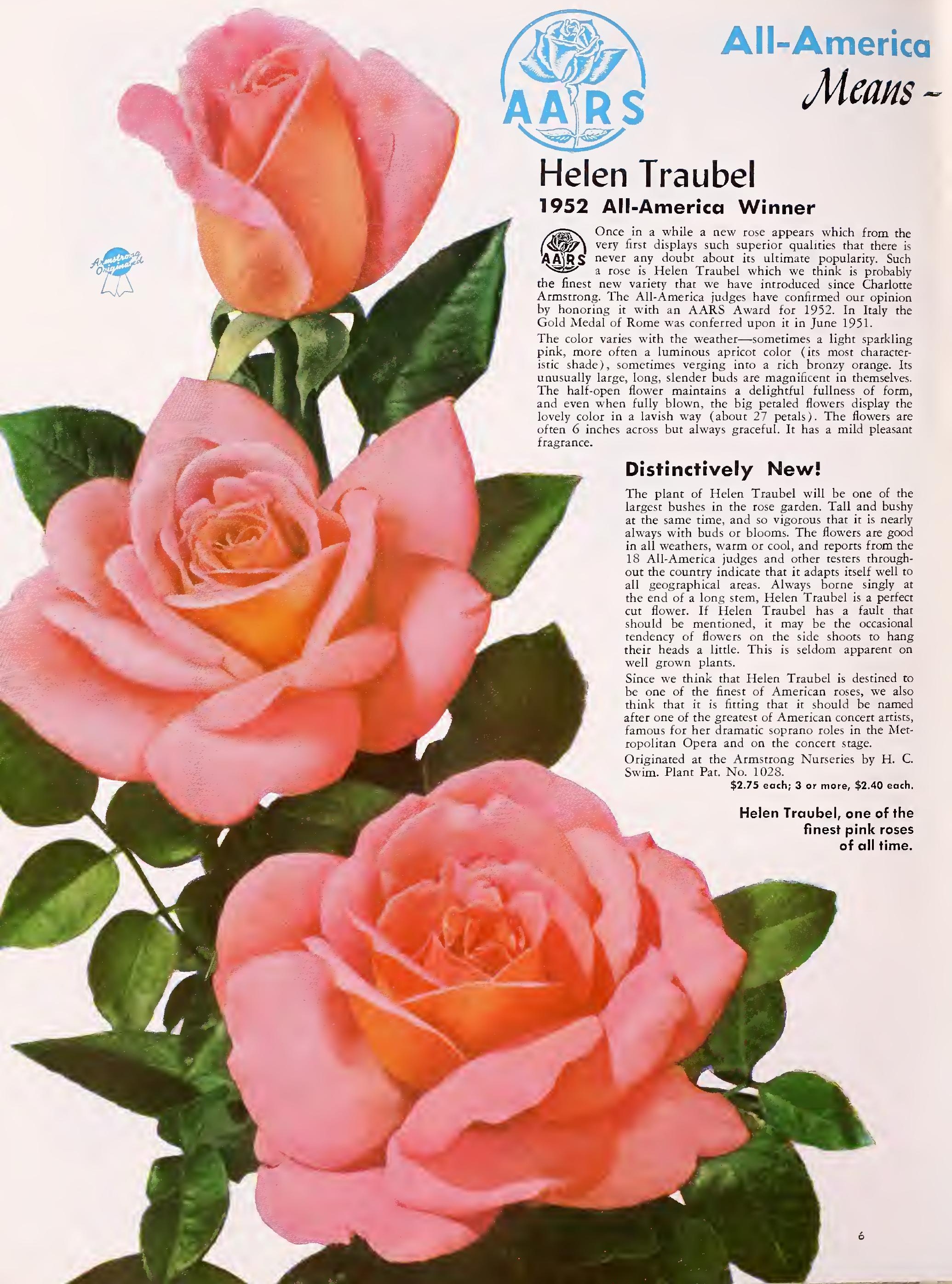




\section{America's Best Roses}

AARS stands for All-America Rose Selections, a national non-profit organization set up to scientifically test all new roses and to select the best in each year's introductions for national awards. AARS is now recognized nationally and internationally as the most important rose testing organization.

All entries are planted for official test in 18 carefully selected AllAmerica trial gardens scattered throughout America and representing each important rose growing climate and location. 18 of the most capable rose judges score these new roses for a 2-year period on a uniform point basis. At the end of each testing period, the scores are totaled and the top-scoring rose or roses are then given All-America Awards. Any new rose origination from any country or from any entrant is eligible to compete. The frnal awards are strictly impartial and are based entirely on the merits of the roses in competition. You can be sure that any AARS Winner (designated in this catalog by the AARS insignia) is a good rose because it has come out on top after a scientific, nationwide, competitive test.

There are three AARS Winners for 1952. One is Helen Traubel, a glorious apricot-pink rose, perfect at every stage, and, we are proud to say, an Armstrong introduction, originated by our Director of Re search, Herbert C. Swim. Another is Fred Howard, a big, double, buff yellow beauty, and the third is Vogue, a handsome flame colored Floribunda rose. AARS competition becomes keener each year and the All-America jury becomes more discriminating in its awards.

There is one characteristic that is outstanding in all of these thrce fine winners-they have strong, vigorous, free blooming plants. This almost guarantees satisfaction in the garden.

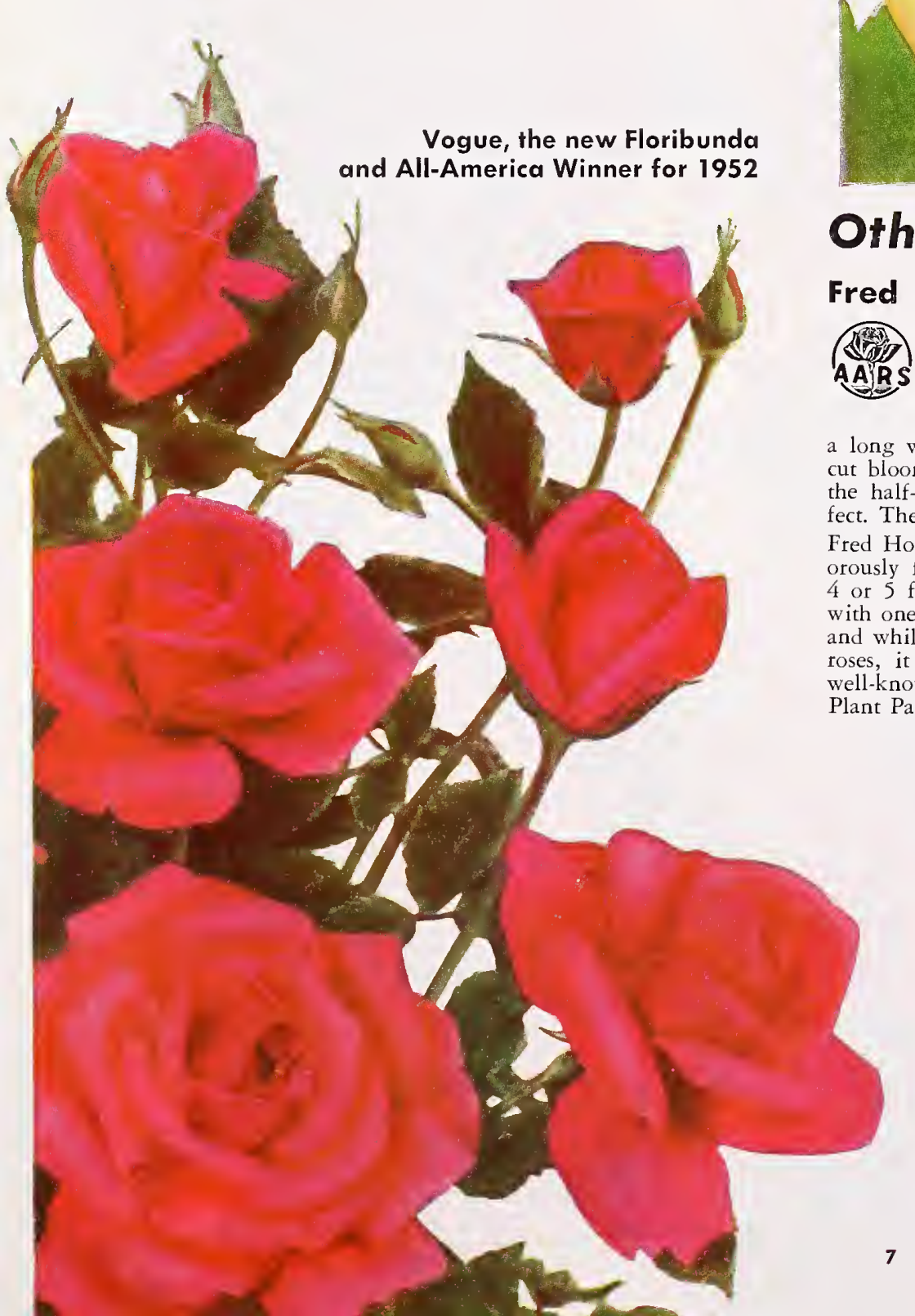

\section{Other 1952 Winners}

\section{Fred Howard}

Here is a new rose which carries all the golden color and robust vigor of the West, where it originated. Its big, 50 petaled, fully double, buff yellow blooms, of ten lightly flushed with pink at the edges of the petals, are far above average in size, and because the flowers open slowly and last long while, full and compact to the very end, they make splendid cut blooms. The beauty of the flower is not in the ovoid bud but in the half-open and fully blown flowers which are nearly always perfect. The fragrance is slight.

red Howard is one of those roses which has a plant that grows vigorously from the very start and in Western gardens will get up to 4 or 5 feet with no trouble at all. The stems are straight and stout, with one fine flower atop each stem. The plant is both tall and bushy, and while the crinkled olive green foliage is not the most beautiful in oses, it covers the plant adequately. Named after its originator, a well-known Southern California nurseryman, the late Fred Howard. lant Pat. No. $1006 . \quad \$ 2.75$ each; 3 or more, $\$ 2.40$ each.

\section{Vogue}

Since good Floribundas are becoming more popu1603 lar throughout the country, we welcome the advent AA) S of this new All-America Winner, with its many beautiful little flame-red buds, long, slender, and flared at the end. The flowers are borne in clusters of from 3 to 10 , opening one after the other until the entire cluster makes a beautiful spray of color. The 16-petaled flowers are a rich, deep coral-pink in color after they open wide, and they make a fine mass display on the plant-as a good Floribunda should.

The plant is medium in height, reaching 3 feet or more in Western gardens, rather open in habit, with small dark green foliage. The plant is spreading rather than slender, and has plenty of vigor so that it keeps producing one crop after another of the beautiful little blooms. In the All-America test gardens it seems to have proved its hardiness in all sections of the country where roses are grown. Originated by E. S. Boerner. Plant Pat. No. 926.

$\$ 2.25$ each; 3 or more, $\$ 2.00$ each; 25 or more, $\$ 1.80$ each. 


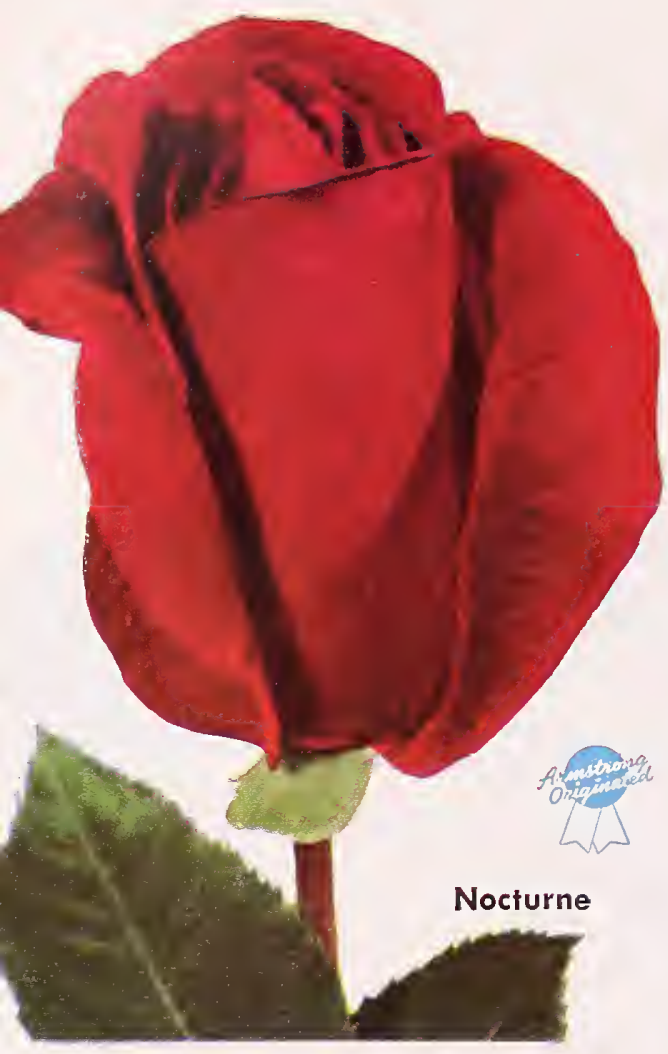

\section{A All-America Collection A A}

For those of you who want the very best of newer roses we offer this collection of five leading winners of All-America Awards. The "cream of the world's newer roses." It includes the great new All-America Winner for 1952, Helen Traubel.

\section{Charlotte Armstrong}

"Queen of Them All," in our opinion. Winner of the sole 1941 All-America Award, and, along with Peace, one of the two most popular roses the country over. Its long, slender, cerise buds and magnificent open flowers are favorites in thousands of gardens.

$\$ 2.00$ each; 3 or more, $\$ 1.75$ each.

\section{Helen Traubel}

The newest rose in this collection, one of the 1952 Winners. Because of the daintiness of its apricot-pink coloring, its long slender buds, and the perfect open flowers, the vigor of the plant and freedom of bloom, we are eager to have you enjoy it in your own garden. You can't help but like it.

$\$ 2.75$ each; 3 or more, $\$ 2.40$ each.

\section{Nocturne}

Every rose garden needs at least one good red rose, and Nocturne will certainly fill the bill. All-America Winner in 1948, its long deep red buds and large richly textured petals make it one of the finest red roses of today.

\section{Peace}

This All-America Winner for 1946 is one of the most beautiful of all roses and has probably won more prizes in rose shows than any other rose in existence. Lovely shades of gold, cream, and pink. The perfect bloom takes your breath away. $\$ 2.50$ each; 3 or more, $\$ 2.20$ each.

\section{Sutter's Gold}

This 1950 All-America Winner has long bright yellow buds shaded red and orange. It is the most fragrant of all yellow roses, and the plant grows and blooms to beat the band. $\$ 2.25$ each; 3 or more, $\$ 2.00$ each.

\section{All-America Collection}

One each of the five All-America roses listed on this page, postpaid anywhere in the States for (Add $3 \%$ sales tax on

California shipments.)

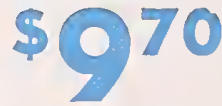

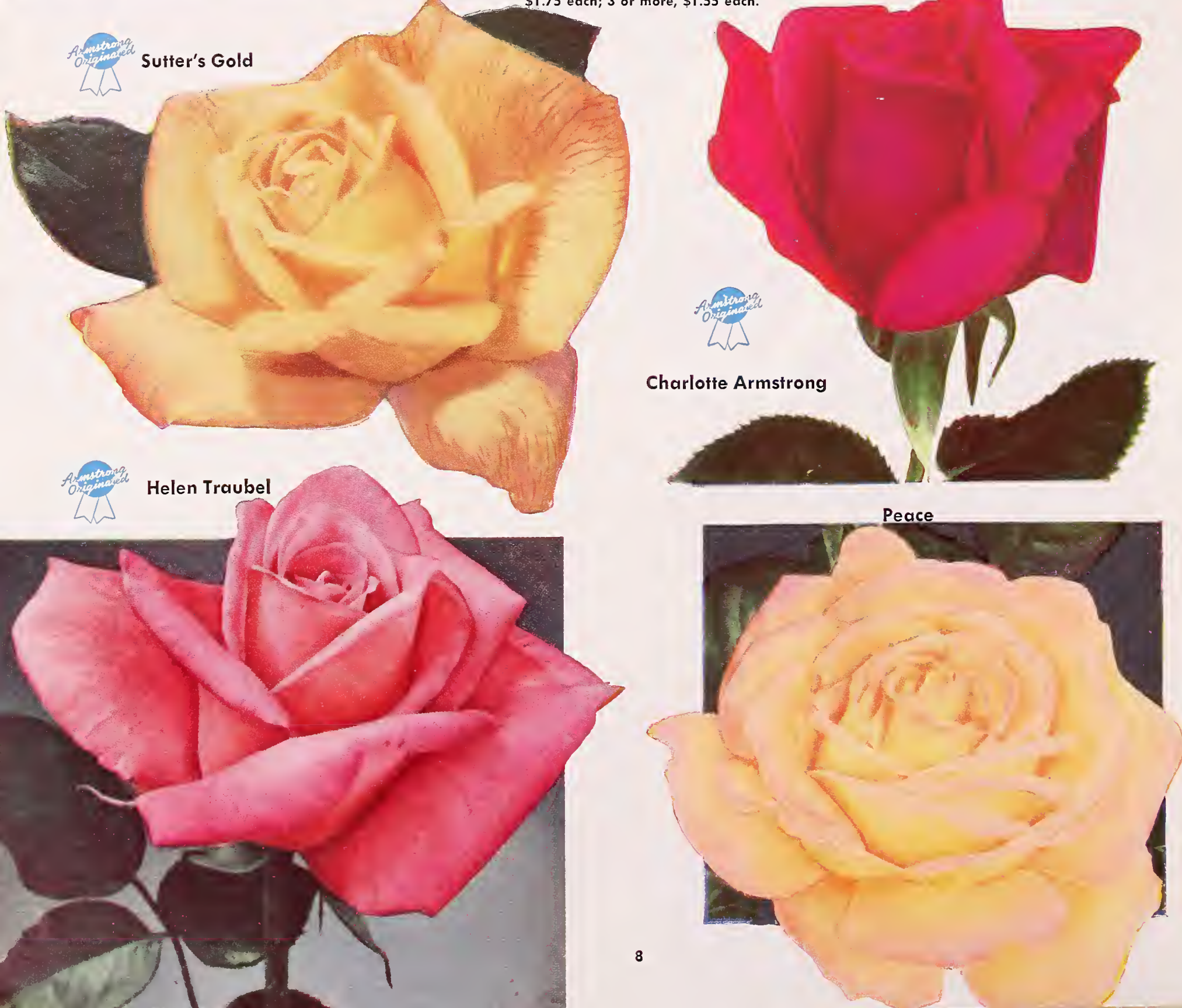


We are not content to just search out the best new roses from other parts of the country and from other lands-we make our own! Skilled plant breeders hybridizing and selecting day after day are working here at Ontario to produce more beautiful new roses than the world has yet seen. And were succeeding, too. We are proud of the fact that more Armstrong roses have been named All-America Winners than those of any other hybridizer in the world. Almost every rose garden in the country now has Armstrong rose varieties as its outstanding performers.

\section{Brand New for "52}

The latest proof of Armstrong success in leading the world in the finest of new roses lies in the two great new varieties, Helen Traubel and Chief Seattle. We think that Helen Traubel, with all its fine qualities and delightful color, may be our finest introduction since Charlotte Armstrong (indeed, Charlotte Armstrong is one of its parents). Chief Seattle, illustrated on this page, is a close second to Helen Traubel, and while not as consistent as that variety in its production of perfect blooms, it has many unusual qualities.

The crosses for these two new roses were actually made ten years ago. It takes that long to grow the seed, bring the seedlings into bloom, observe them, test them, enter them in nationwide competition, and finally to grow the plants for your garden. But it's worth it when we can get two fine kinds like Helen Traubel and Chief Seattle.

\section{Chief Seattle}

Here is a beautiful and unusual rose. A new Armstrong introduction, offered this year for the first time, it carries a rich shade of buff apricot. It does become paler at times and the color is not quite as uniform as shown in the illustration, since the face of the petal is always lighter than the reverse side. The flower is above average in size, is many-petaled and high-centered (45-60 petals), opens very slowly on the bush, and lasts for a long time.

In the bud the many petals are ruffled, giving it a delightfully graceful and dainty appearance, and it has a rich tea fragrance to enhance its rich coloring. It is one of those roses which is good-looking both in the bud and the open flower. The plant of Chief Seattle is extremely vigorous, with great quantities of luxuriant olive green foliage. The stems are remarkably long and straight and never have more than one bud to the stem. These qualities make it one of the finest roses for cutting that we have ever seen. The plant is large and bushy, with a compact shape which looks well in the garden.

The Seattle Rose Society and the park officials of the City of Seattle selected this new rose as the one which they wished to name "Chief Seattle" in honor of the Indian Chief who founded Seattle 100 years ago. It has been widely planted in Seattle parks and is the official rose of the Centennial Celebration of the City of Seattle, to be observed in the year 1952. In California this rose is so full and many-petaled that it does not always open up perfectly in the first spring bloom, if the weather is cool and damp. Later on in the summer, and always in the fall, it produces magnificent flowers in California.

Originated by Herbert C. Swim at the Armstrong Nurseries. Plant Pat. No. 1030.

$\$ 2.50$ each; 3 or more, $\$ 2.20$ each.

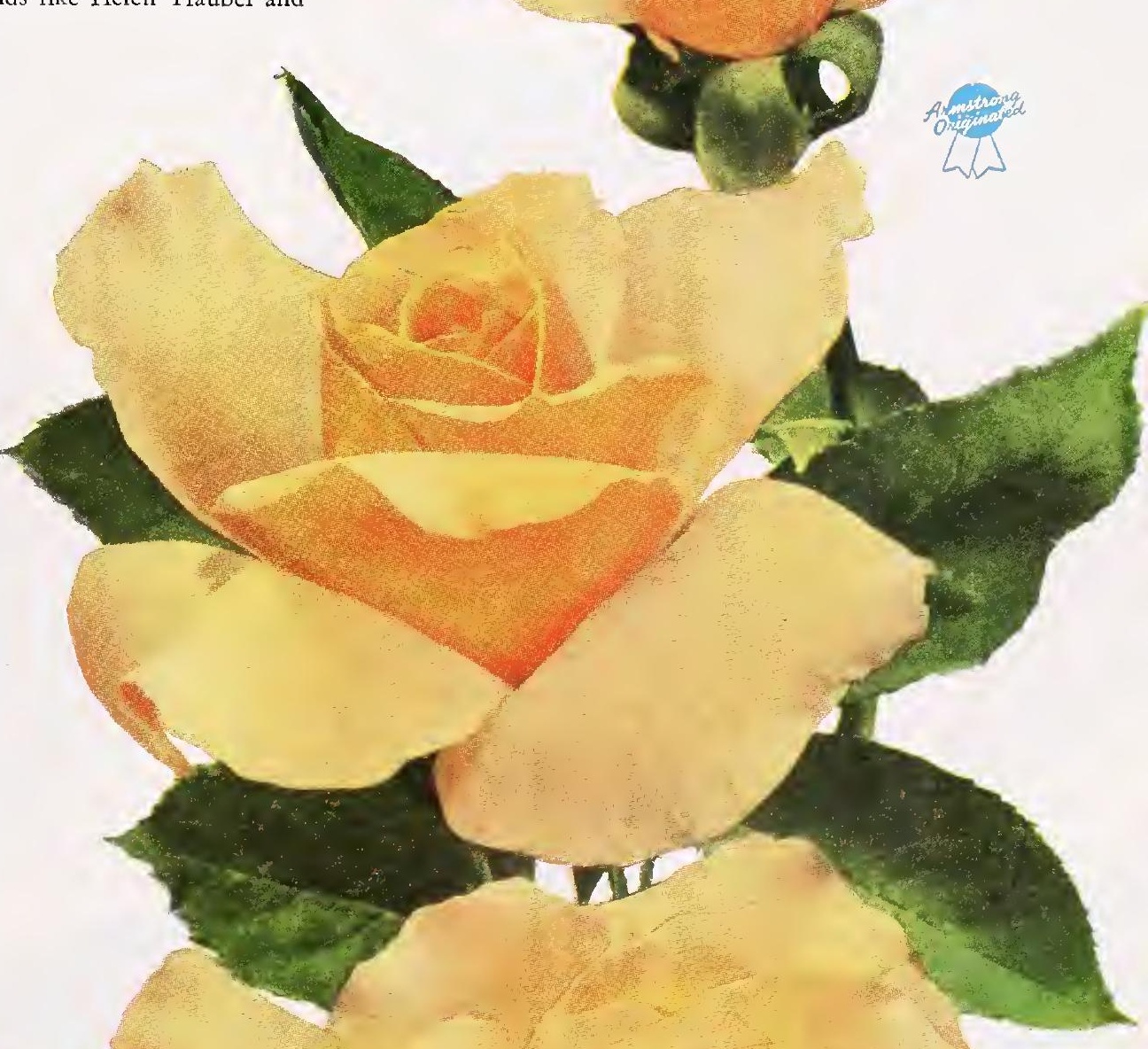

\section{The

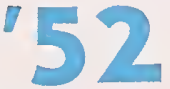 \\ Collection}

The two great new Armstrong rose introductions for 1952, Helen Traubel and Chief Seattle -one plant of each for

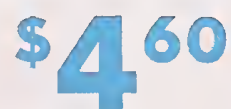

Shipped postpaid at proper planting time.

(Add $3 \%$ sales tax on California shipments.)

\section{The new rose Chief Seattle shown at right}

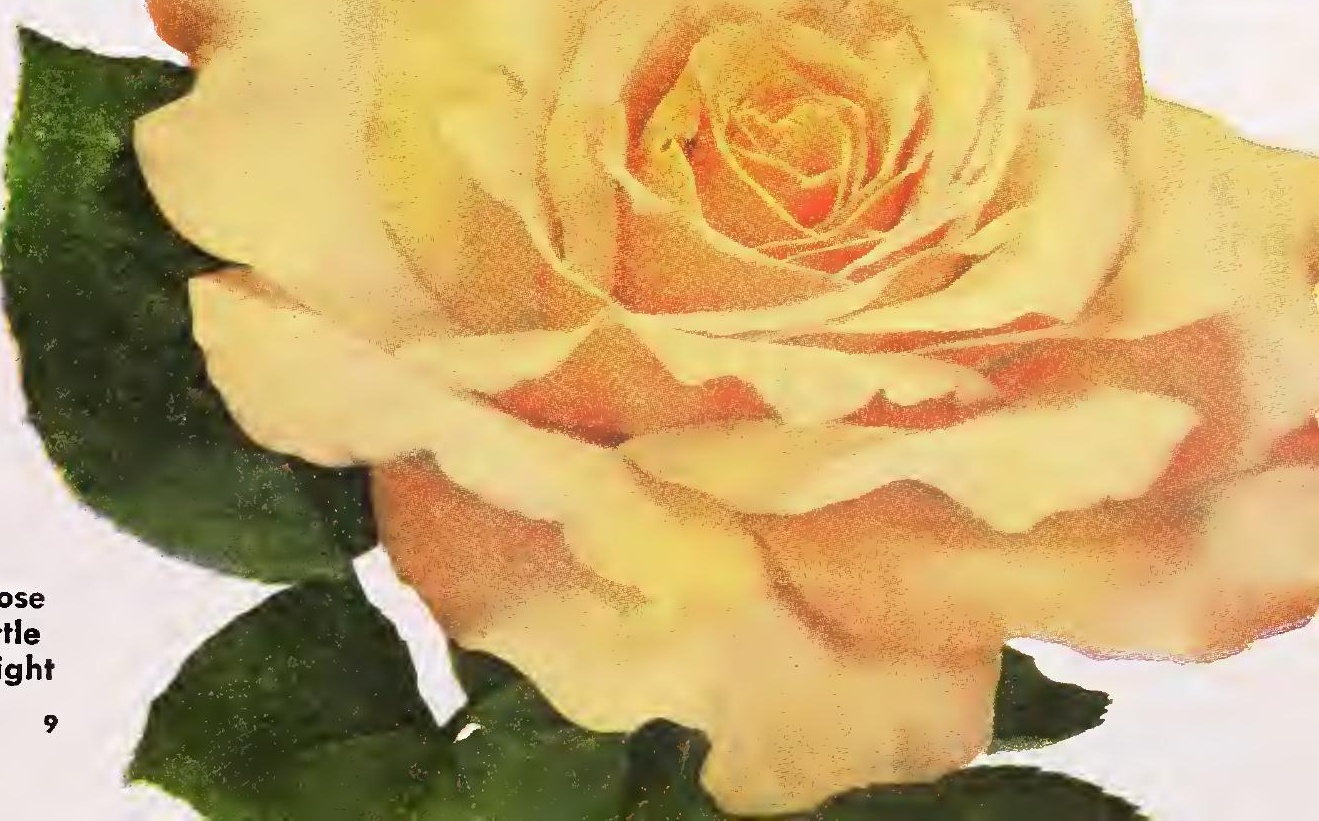





\section{Rose Creations From the World's Leaders in the}

\section{First Love}

If you would like (and who wouldn't) dozens of exquisitely graceful and distinctive long, tapering buds in a delightful shade of pale dawn pink, then this is sure to be the "first love" in your garden. In certain weathers, the delicate color is tinted with lovely pastel shades of salmon, orchid and rose. The flowers, with their mild, pleasant tea fragrance and gracefully pointed petals (about 25), open very slowly, have a crisp long-lasting substance.

The plant is very vigorous, fairly upright in habit with every flower borne singly on a long, slender stem, ideal for cutting. Free-branching and free-blooming, it is a delight to grow, but your biggest delight will be in cutting the exquisite buds. Originated at the Armstrong Nurseries by H. C. Swim. Plant Pat. No. 921.

$\$ 2.25$ each; 3 or more, $\$ 2.00$ each.

\section{Bravo}

Here is a big, bold, red rose which will completely steal the show at the peak of its bloom in your garden. We have never seen anything to equal its brilliant cardinal red color, nor a rose which will hold color as it does-even in the hottest weather. The rather plump bud of average length opens to a spectacular big, broad flower with beautifully ruffled petals arranged in perfect symmetry.

Don't expect much fragrance, and don't expect a big plant like that of Charlotte Armstrong or Sutter's Gold--this one has given everything to color and form. The plant grows to medium height and has a rather bushy habit. When it blooms in your garden, you'll exclaim, "Bravo!" many times over. Originated at the Armstrong Nurseries by H. C. Swim. Plant Pat. No. 983.

$\$ 2.25$ each; 3 or more, $\$ 2.00$ each.
Sutter's Gold

The First American Rose to Win Top National and Infernational Awards

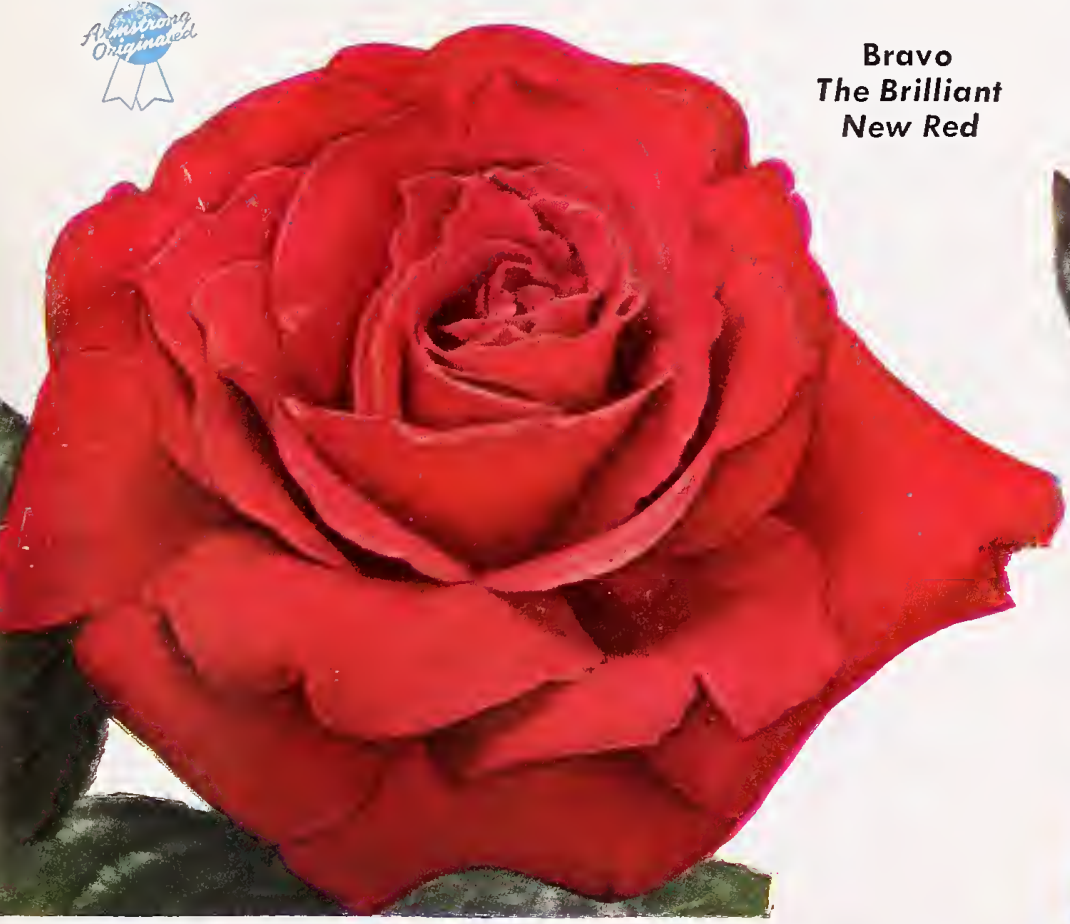

\section{Brilliant}

Sutter's Gold

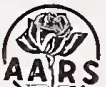

This was the first rose from any country to make almost a clean sweep of the top national A. ASS and international rose awards. In addition to an All-America Award for 1950, Sutter's Gold won the Foreign Gold Medal at the famous Bagatelle Trials in Paris, France, and following that won top honor, the Gold Medal, at the Geneva Rose Trials in Switzerland.

The great charm of this rose is in the sheer perfection of its long, pointed, yellow buds which are richly shaded with orange and red. They open to a high-centered golden yellow flower (about 24 petals) with a tea fragrance richer than in any other yellow rose. Occasionally, in adverse weather, the flowers tend to open a bit quickly, but this is its only fault.

Few roses can boast a plant so strong and vigorous. Growing rather tall and upright, it is always covered with an abundance of large glossy leaves which are highly resistant to foliage trouble. From everywhere come the same enthusiastic reports on Sutter's Gold-a big husky plant, long stems, and plenty of beautiful buds. Originated at Armstrong Nurseries by H. C. Swim Plant Pat. No. 885. $\$ 2.25$ each; 3 or more, $\$ 2.00$ each. Quantity rates apply to 3 or more of the same variety only. 


\section{Armstrong}

\section{Fandango}

For brilliant eye-catching color, continuity, and quantity of bloom, we think Fandango is unbeatable. Deep scarlet in the bud, the opening flowers are an unbelievably gay and bright Chinese red and they remain attractive until the last petal falls. The good-looking buds open rather quickly to a large ruffled flower (16 to 25 petals) with a crispness to match its brilliance. True, there is loss of petalage and size during very hot weather, but the big, tall, vigorous plant is usually covered with brilliant bloom before other kinds start and after they stop. Originated in the Armstrong Research Department by H. C. Swim. Plant Pat. No. 894.

$\$ 2.00$ each; 3 or more, $\$ 1.75$ each.

\section{Juno}

In no other rose are large size, clear color, perfection of form and longlasting substance combined to such a degree. It will give you magnificent individual flowers for cutting - real exhibition roses-big, yet perfect in every detail. The color is clear, bright pink without other shadings. The flower ages to a soft silvery pink, but never loses its soft rich coloring. We can't have everything in a rose, so don't expect lots of flowers and don't expect a big tall-growing bush. It is a sturdy plant of medium size, with stout heavy stems abundantly clothed with large leathery foliage. Every bloom it produces is delightful and lacks only fragrance to be sheer perfection in a rose. Originated in the Armstrong Research Department by H. C. Swim. Plant Pat. No. 895 . $\$ 2.00$ each; 3 or more, $\$ 1.75$ each.

\section{The 1949 AARS Winners}

\section{Forty-niner}

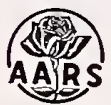

Undoubtedly this is the most brilliant of all bicolors. It is so startling in its contrasting colors and the colors are so bright, that it is hard to believe that they could both be present in the same flower. Inside, the petals are a vivid Orient red, changing to cherry red with age. Outside, they are chrome to straw yellow. The colors are paler in some weathers. The buds are delightfully formed, opening into a large, well-shaped, pleasantly fragrant flower of 25 to 40 petals. The vigorous plant is tall and upright, and the stems are long, straight and sturdy, with few thorns. An All-America Winner for 1949, it was originated in the Research Department of Armstrong Nurseries by H. C. Swim. Plant Pat. No. 792. $\$ 2.00$ each; 3 or more, $\$ 1.75$ each.

\section{Tallyho}

Tallyho combines most of the desirable rose characteristics (10) with a color entirely new. Inside, the petals are a delightful AAR S shade of pink (technically Tyrian Rose), while the reverse side is a brilliant crimson. The tall robust plant has proved to be very hardy (proved in areas like Minnesota). It branches continually, throwing out long straight flower stems, each crowned with a beautiful ovoid bud which opens to a magnificent, large, highcentered, fully double flower of exquisite shape. The fragrance is spicy and full-bodied. Originated in the Armstrong Research Department by H. C. Swim. Plant Pat. No. 828.
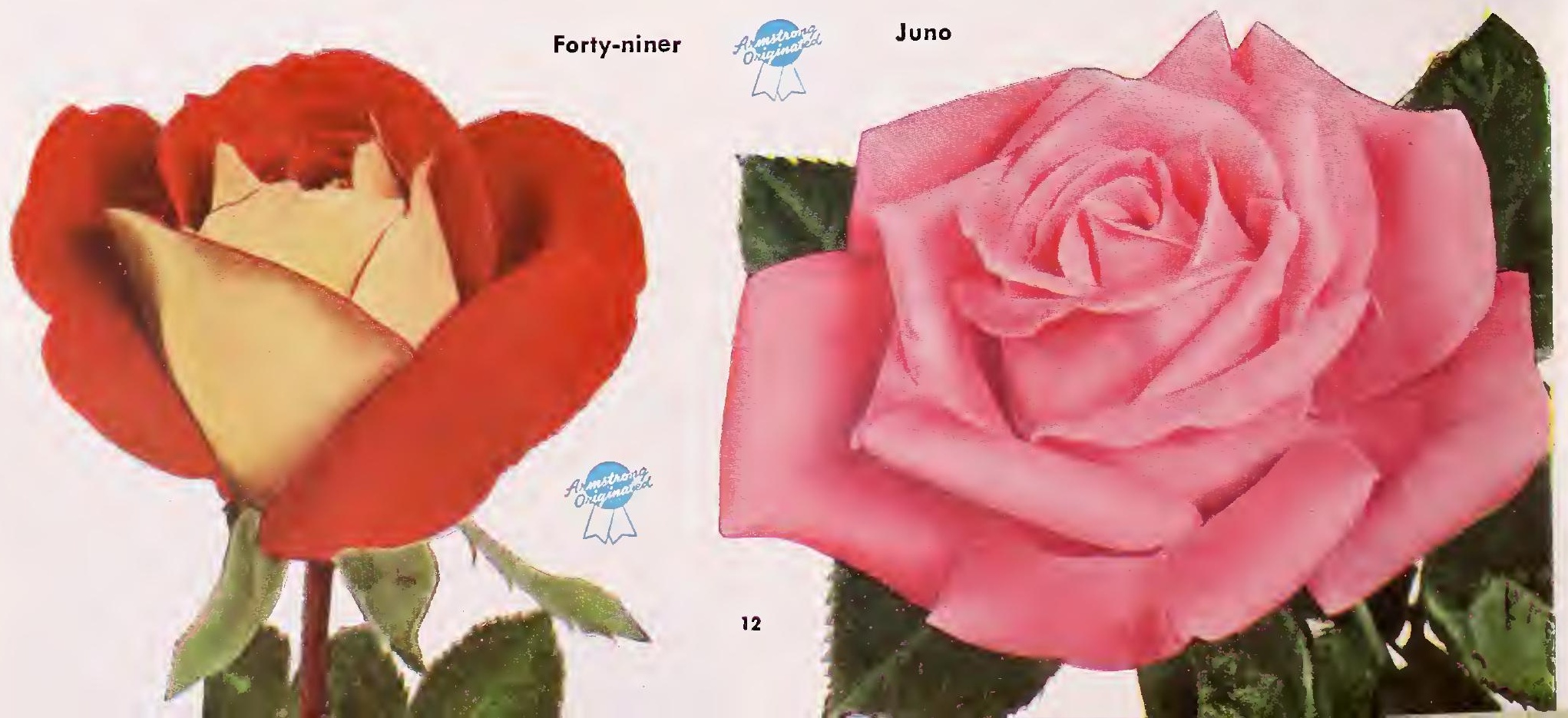


\section{Rose Creations}

\section{Two 1948 AARS Winners}

Nocturne

Recent national rose polls rate Nocturne among the three (17) or four best red roses in the country today, and it's easy to AAKS see why. Beautifully shaped long dark buds open to big many-petaled mildly fragrant flowers with plenty of longlasting substance. The color is a deep velvety crimson with darker pools of maroon, the colors becoming lighter and brighter in warm weather. The bush is big and sturdy with stems long and strong and the foliage luxuriant. Nocturne is a rose which seems to do well everywhere. Originated in the Armstrong Research Department by $\mathrm{H}$. C. Swim. Plant Pat. No. 713.

$\$ 1.75$ each; 3 or more, $\$ 1.55$ each.

\section{Taffeta}

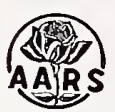

Taffeta is a rose which will intrigue you with a different array of color with each change in the weather. Carmine rose AnRS in the bud, it changes to begonia rose with underlying tones slender bud opens to a large flower with about 21 delicately frilled petals and a very pronounced fragrance. The plant is larger than average, vigorous and upright, with the new growth mahogany red changing to dark, glossy green. Taffeta does not have the same resistance to mildew as Charlotte Armstrong, but it does wonderfully well in all sections of the country. Originated in the Armstrong Research Dept. by W. E. Lammerts. Plant Pat. No. 716.

$\$ 1.75$ each; 3 or more, $\$ 1.55$ each.

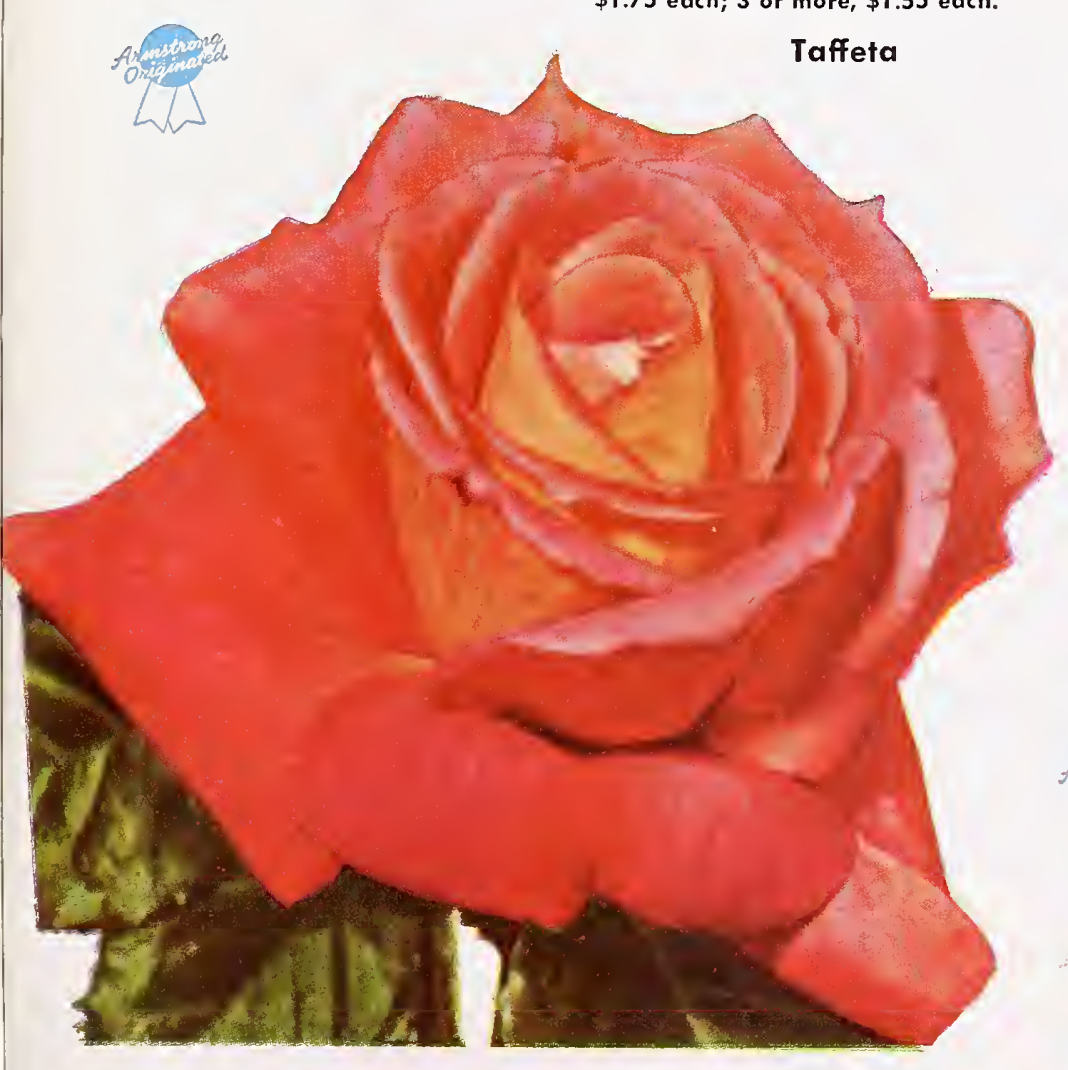

Mirandy

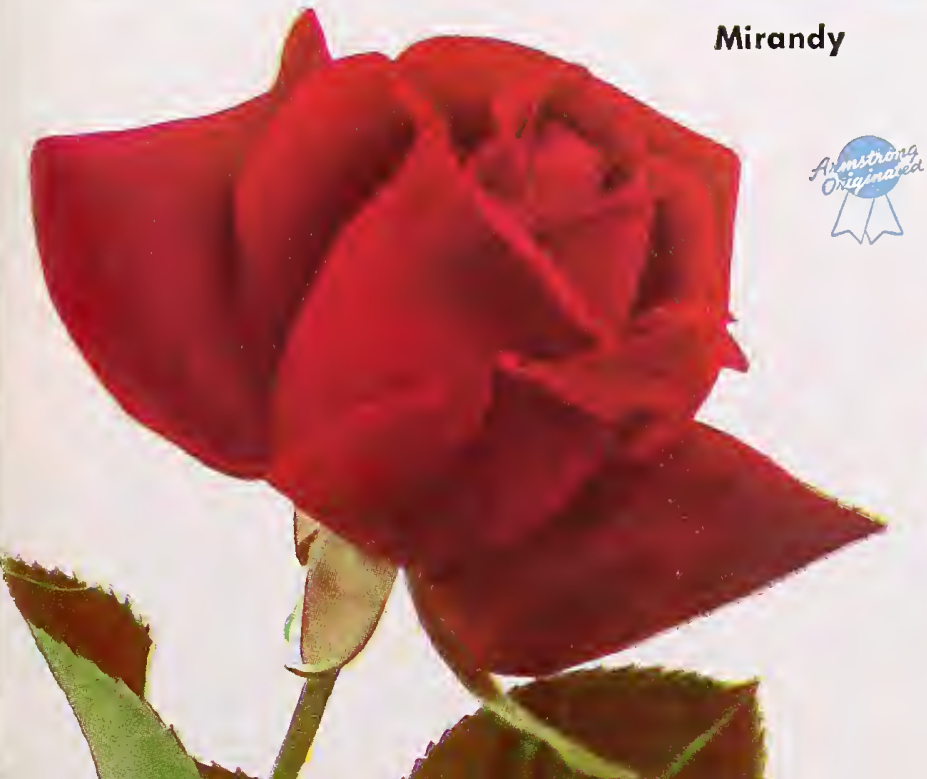

\section{Mirandy}

The top All-America Winner for 1945, Mirandy features W02 big ovoid buds of deep red. The flower displays new A A RS beauties of form as the petals unfold, eventually becoming a huge full bloom ( 50 petals) of dark glowing red with the most delicious full-bodied fragrance you have ever inhaled. Mirandy is best in sunshine and warm weather. In the cool foggy areas of the Pacific Coast, the flowers do not always open perfectly, but when they are right, they are unbeatable. Plants medium in height, vigorous, and free-branching. Originated in the Armstrong Research Dept. by W. E. Lammerts. Plant Pat. No. 632.

$\$ 1.75$ each; 3 or more, $\$ 1.55$ each.

\section{Valentine A New Floribunda}

This new Armstrong introduction for 1951 fills a long-felt need in the Floribunda class. Now for the first time we have a slow-growing Floribunda in a truly brilliant shade of red. You will find it fully described on page 25. Plant Pat. No. 1029.

$\$ 2.00$ each; 3 or more, $\$ 1.75$ each; 25 or more, $\$ 1.60$.

Quantity rafes apply on 3 or more of the same variefy only.

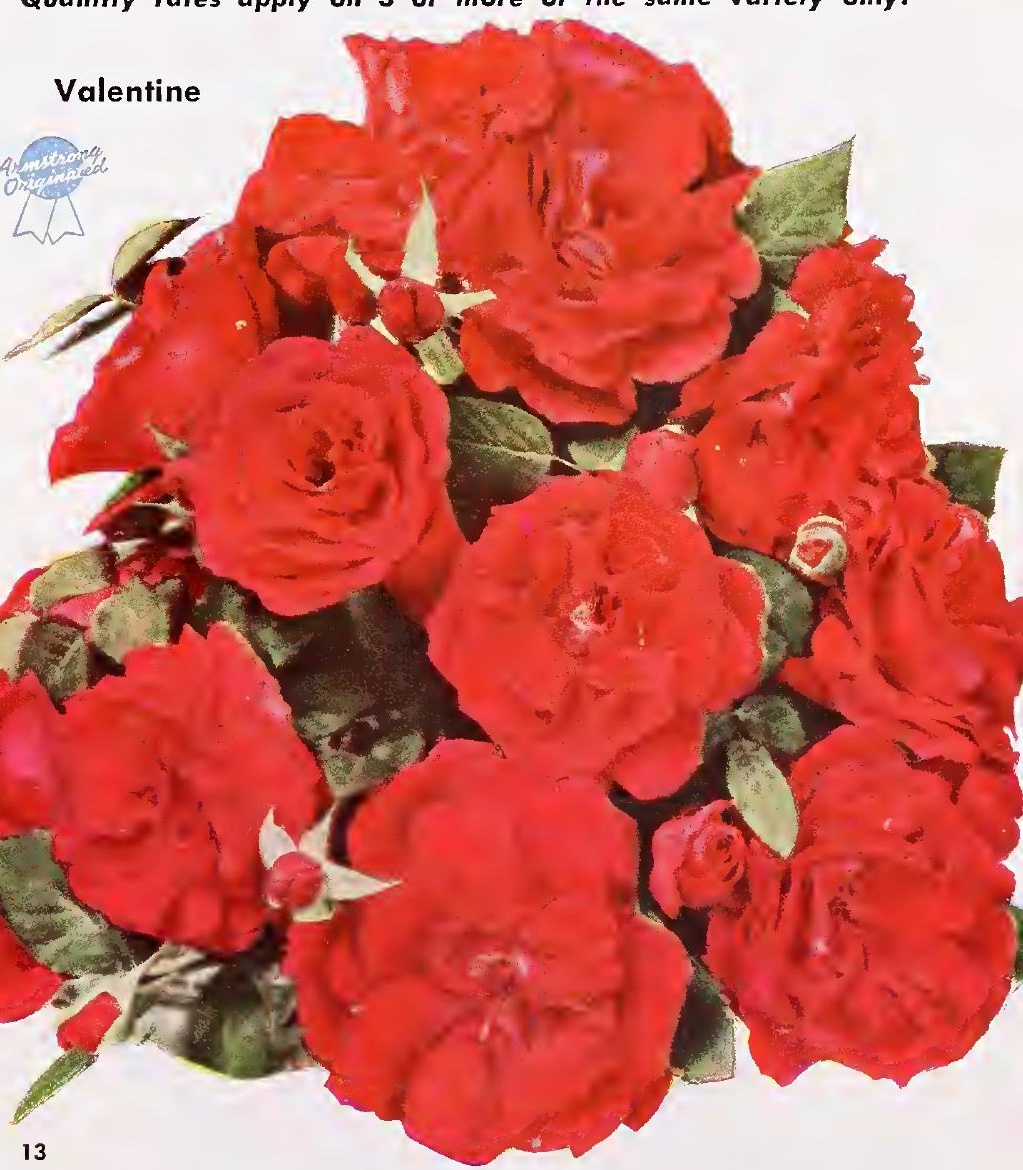




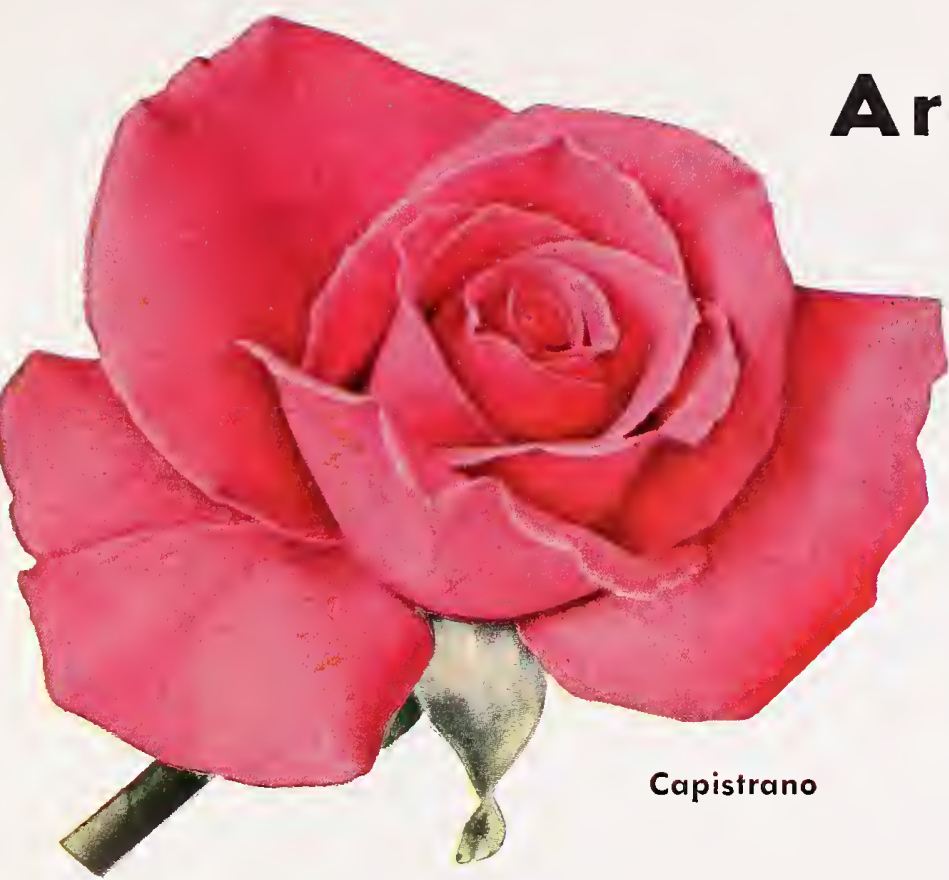

\section{Capistrano}

This magnificent big pink rose was an All-America Selection (10. for 1950. Big, long, beautifully formed buds in a sparkling AARS shade of clear rose pink open to extremely large full flowers (about 30 petals) with a pleasant mild fragrance and plenty of long-lasting substance. The beautiful clear color is retained until the last petal drops. This variety has one of the largest and most sturdy plants to be found in rosedom, with long, heavy, straight stems and large leathery foliage. Plant Pat. No. 922.

$\$ 2.25$ each; 3 or more, $\$ 2.00$ each

\section{Countess Vandal}

A rose which is just about as fine as anything we know of in the salmonpink class. The Countess continually produces many long, tapered buds of salmon-pink shaded with copper and gold. The flowers are fine for cutting because they are richly tragrant, always come on long, sturdy stems, and are nearly always available. Buds and open flowers are usually perfect, no matter what the weather, and they keep exceptionally well. The vigorous bushy plant with its large leathery foliage thrives and blooms consistently in all rose growing sections.

$\$ 1.50$ each; 3 or more, $\$ 1.30$ each.

\section{Quantity Rates}

You can save substantially by ordering 3 or more roses-and you'll get a lot of pleasure from several plants of one variety. Three different varieties cannot be sold at the quantity rate. You save substantially on the collections, too, but please do not ask for substitutes.

Countess Vandal 


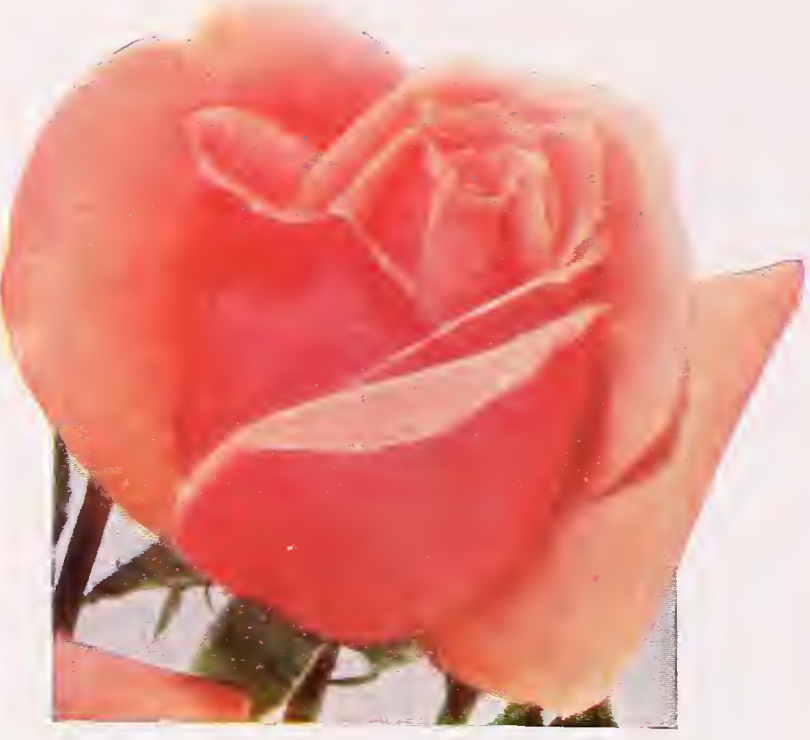

Horace McFarland

\section{You Pay No More}

You may as well enjoy Armstrong quality no matter where you live for it costs no more. All bare root roses are packed and shipped to reach you in perfect condition anywhere in the U.S. And-it is all done at our expense. (Small packing charge for tree roses.)

\section{Christopher Stone}

Such a vivid color could not long go unnoticed in any garden. The glowing brilliant crimson-scarlet flowers, with deeper shadings, never have a trace of blue and do not fade in the hottest sun. Not all of the buds are perfect in form, but they have a longlasting substance and a delightfully spicy fragrance. Fully blown, this rose is as beautiful as any rose you will ever find. $\$ 1.25$ each; 3 or more, $\$ 1.10$ each.

\section{Dainty Bess}

Single roses are quaintly charming whether you see them in a garden or in a vase arrangement, and Dainty Bess is deservedly the most popular of them all. The large five-petaled flowers are a warm pink overlaid with a flush of suntan, punctuated with maroon stamens. The tall strong bush is an almost continuous source of blooms which last a long time after they are cut. The flowers form in clusters of three or more. $\$ 1.25$ each; 3 ar mare, $\$ 1.10$ each.

\section{Etoile de Hollande}

This magnificent red rose is ranked among the best in its color class. The medium-sized buds of velvety maroon open beautifully and cleanly to a marvelous flower of glowing crimson with darker shadings. Each petal holds its brilliant color until it drops. A heavy, delightful old-rose fragrance adds to its charm. The medium-tall bush is strong, free-branching and healthy, with the leaves large, green and fresh looking. $\$ 1.50$ each; 3 ar mare, $\$ 1.30$ each.

\section{Fred Edmunds}

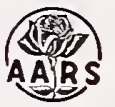

This is a rose which never fails to attract attention because of the brightness of its unusual and enchanting orange color. Vivid orange buds open to large flowers (about 20 petals) in a captivating shade of apricot-orange. The form is no always perfect, but the color and a delicious fruitlike fragrance more than make up for this. The plant is low-growing but vigorous, and the glossy foliage is exceptionally attractive. A rose which is at its best in the cooler sections, it was awarded All-America honors for the Pacific $\$ 1.75$ each; 3 ar mare, $\$ 1.55$ each.

\section{Golden Rapture}

With this variety in your garden, you can cut some of the loveliest long-pointed buds of solid yellow that you have ever seen, morning after morning. You will never cease to admire the sheer perfection of form and, in favorable weather, the brilliance of color in both bud and open flower. The plant, with its shiny foliage, grows to medium height and never fails to carry plenty of buds and flowers with a mild old-rose fragrance. $\$ 1.25$ each; 3 ar mare, $\$ 1.10$ each.

\section{Golden Rapture}

\section{Grande Duchesse Charlotte}

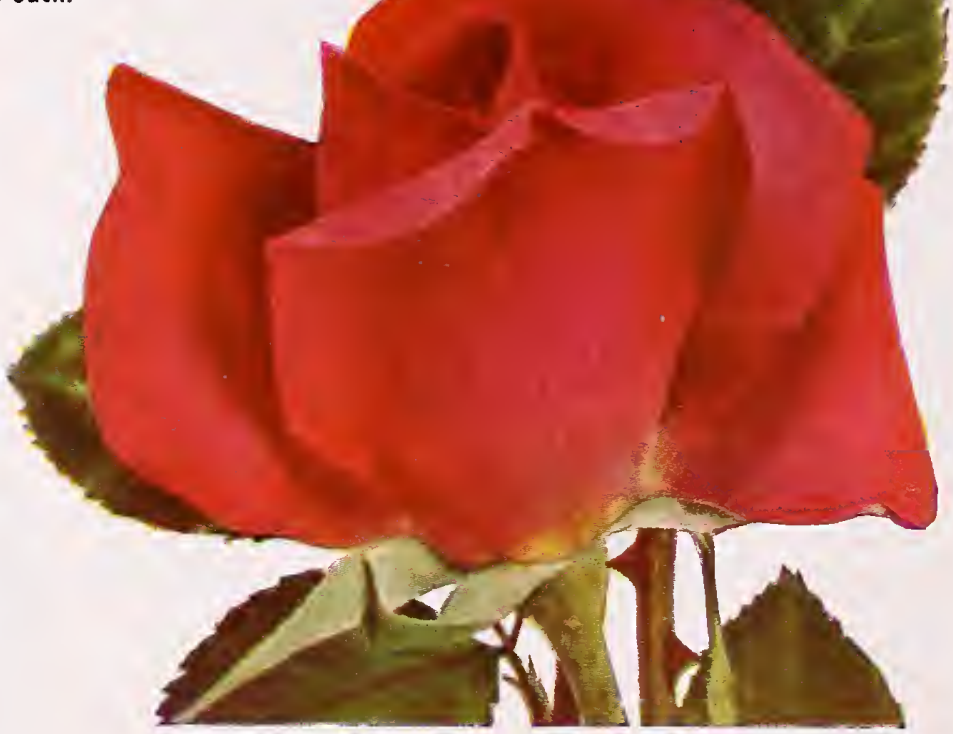

Dainty Bess 


\section{Bush Roses}

\section{Girona}

You will derive a lot of pleasure from growing this multicolored Spanish beauty because of its great vigor, the extremely handsome buds and flowers, and the fine fragrance. The large yet graceful buds open to magnificent, full, double flowers in beautifully varying tones of pink, yellow, and carmine. They have a lot of substance and keep exceptionally well when cut. The bush is a big, tall-growing, free-blooming one which does well in all rose-growing areas. \$1.25 each; 3 or more, $\$ 1.10$ each.

\section{Grande Duchesse Charlotte}

An All-America Award Winner in 1943, this rose is outstanding for its (1D) unique color and its intriguing perfume. The interesting buds are a rich AARS claret color (you may call it brick-red) which changes as the flower ages to a lovely Begonia Rose. The flowers are not always perfect in form, but they are always beautiful because of that rich color, never before seen in a rose. You'll enjoy this rose in your garden when you see the big, strong, free-branching plant with its uniquely colored flowers and sniff the rich fruit-like fragrance. Plant Pat. No. 774.

$\$ 1.75$ each; 3 or more, $\$ 1.55$ each.

\section{Horace McFarland}

An All-America Winner for 1945 and a good solid rose in every respect. 100 The long-pointed, orange-pink buds are extraordinary for their length and AA RS beauty of form. In the bud the color is more orange than pink, and as the big fully double flower opens it becomes a deep apricot-pink with lighter shadings of salmon and coral-pink. The plant is tall, upright, and vigorous, with long straight stems and broad leathery foliage. Moderately fragrant. Plant Pat. No. 730 .

$\$ 1.75$ each; 3 or more, $\$ 1.55$ each.

\section{Special Offer}

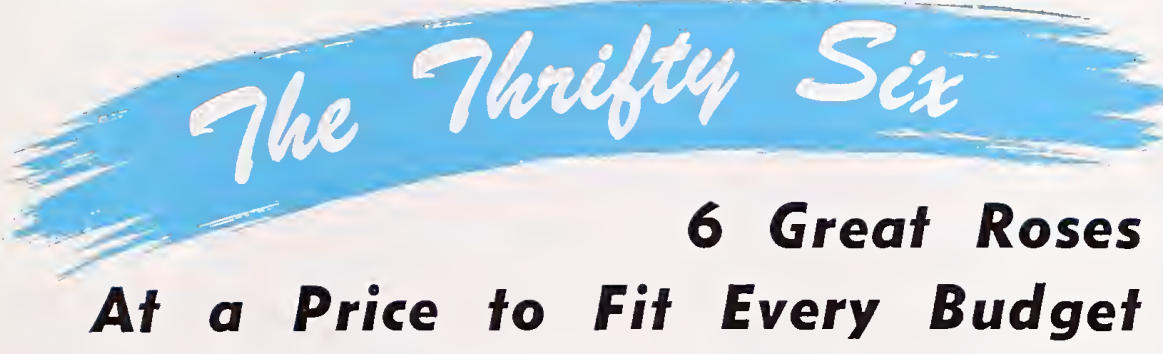

If you want a selection of really fine roses at an unusually low price, here it is. These six famous roses have proved their merit all over the country, and you can be sure they will thrive and flower freely in your garden. Soon after you plant you will be picking gorgeous blooms in a variety of brilliant colors-you really will have a complete little rose garden. By the way, what more welcome gift could you find for the friend or relative who is just starting to landscape that new home?

\section{Christopher Stone \\ Countess Vandal Etoile de Hollande Girona \\ Mrs. E. P. Thom \\ Picture

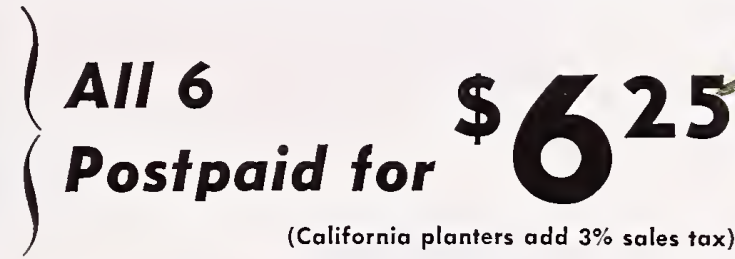

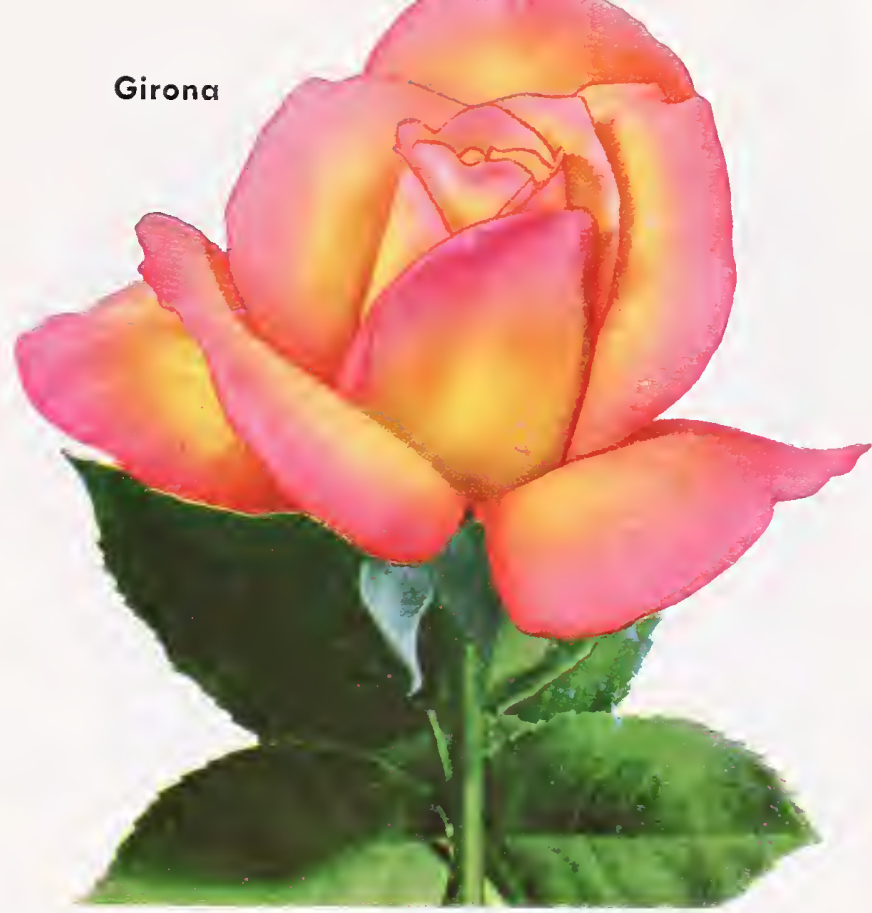

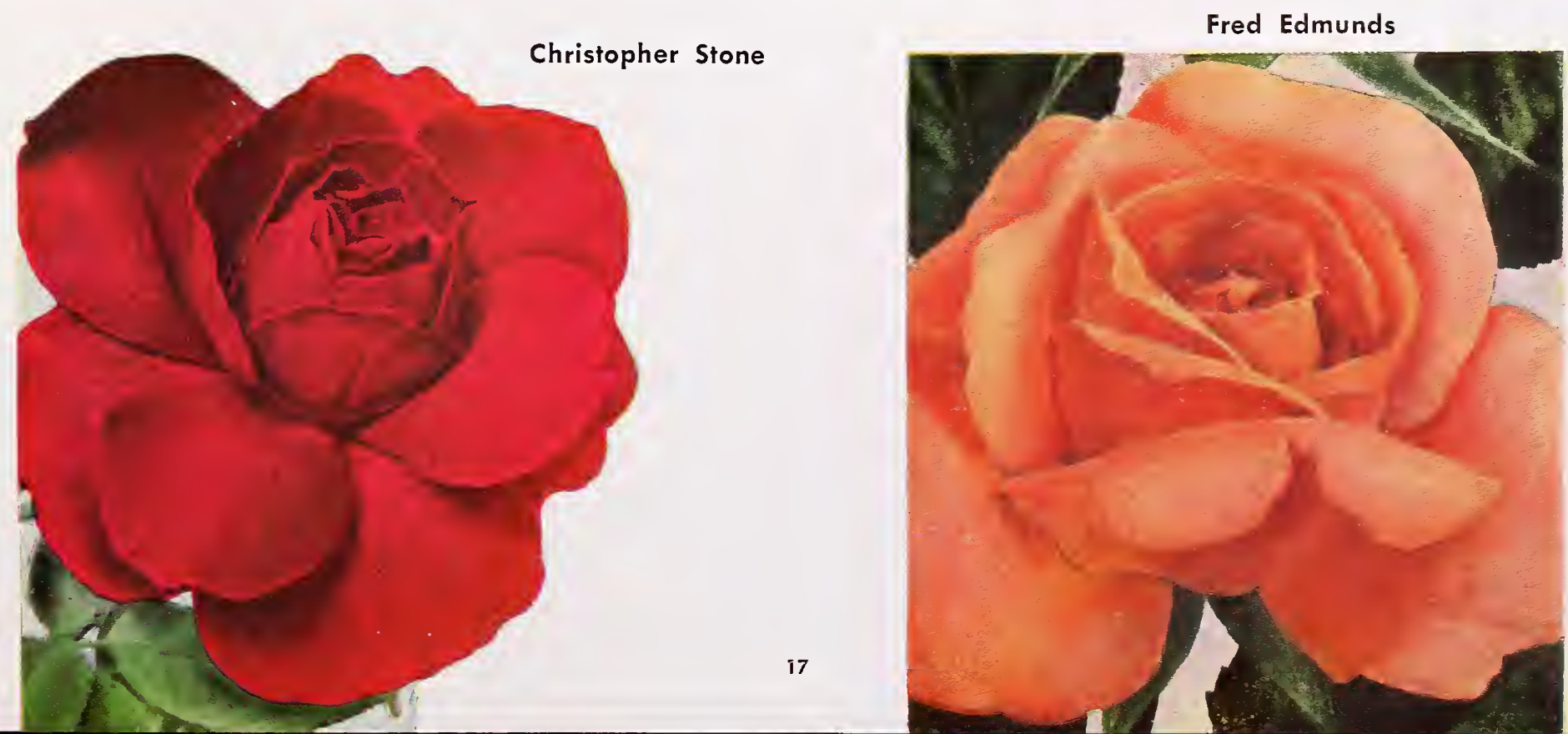




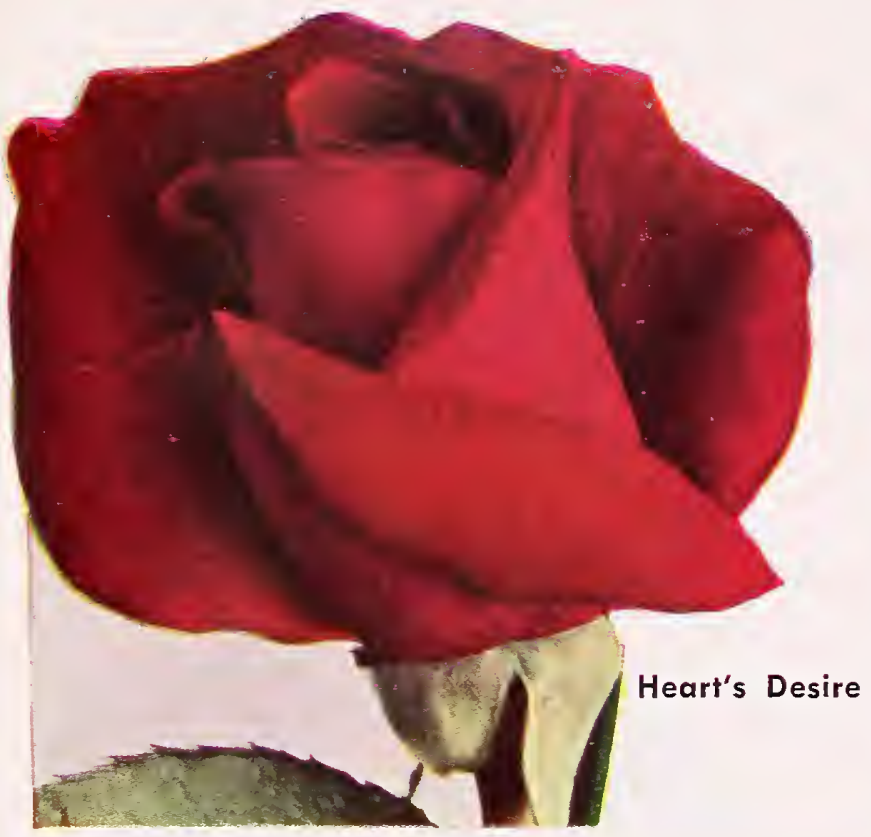

Armstrong

\section{Heart's Desire}

This 1942 All-America Winner has long-pointed buds of bright lumQOD inous red without orher shadings. The flowers are always borne on long AAIRS stems, and keep longer than most other kinds after they are cur. But the most outstanding feature of the rose is its superb fragrance. $A$ few blooms will perfume an entire room. Occasionally there is a weak neck or a globular flower, but few can resist the clarity of color and the wealth of fragrance. Plan Pat. No. 501

$\$ 1.75$ each; 3 or more, $\$ 1.55$ each.

\section{Katherine T. Marshall}

Winner of an All-America Award in 1944, this variety has been N17 chosen by All-America Selections as one of the top ten AARS WinAA R S ners. The flowers are a warm clear pink without other shadings. There Are not many petals (about 22), but all are big and heavy-textured, forming a magnificent bud and half-open bloom, with a rich fragrance. It has some of the biggest, most luxuriant and handsome foliage to be found among the newer roses, and an exceptionally robust plant. Plant Pat. No. 607.

$\$ 1.75$ each; 3 or more, $\$ 1.55$ each.

\section{Lowell Thomas}

This All-America Winner for 1944 is one of the finest of all yellow roses. (10) The big robust tall growing plant flowers freely, and every bloom is borne AASS on a heavy stout stem. Long, tightly furled buds open into large highcentered flowers ( 35 to 40 petals) of bright canary yellow. Planters re-

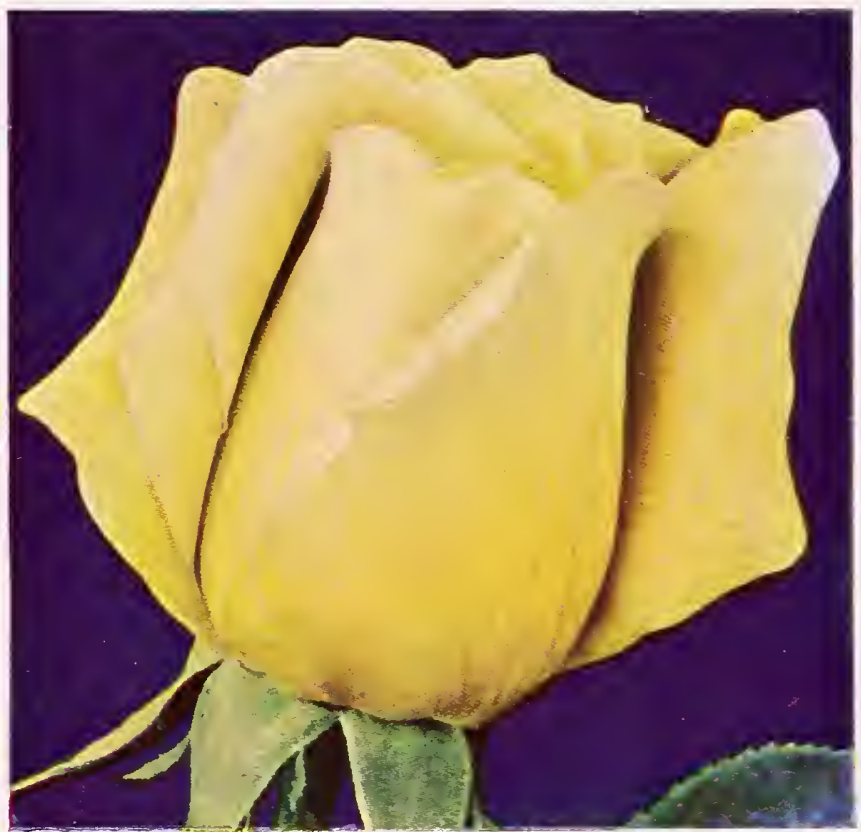
port this is one yellow rose which does well in all areas, and in hot wearher or cool. Plant Pat. No. 595. $\$ 2.00$ each; 3 or more, $\$ 1.75$ each.

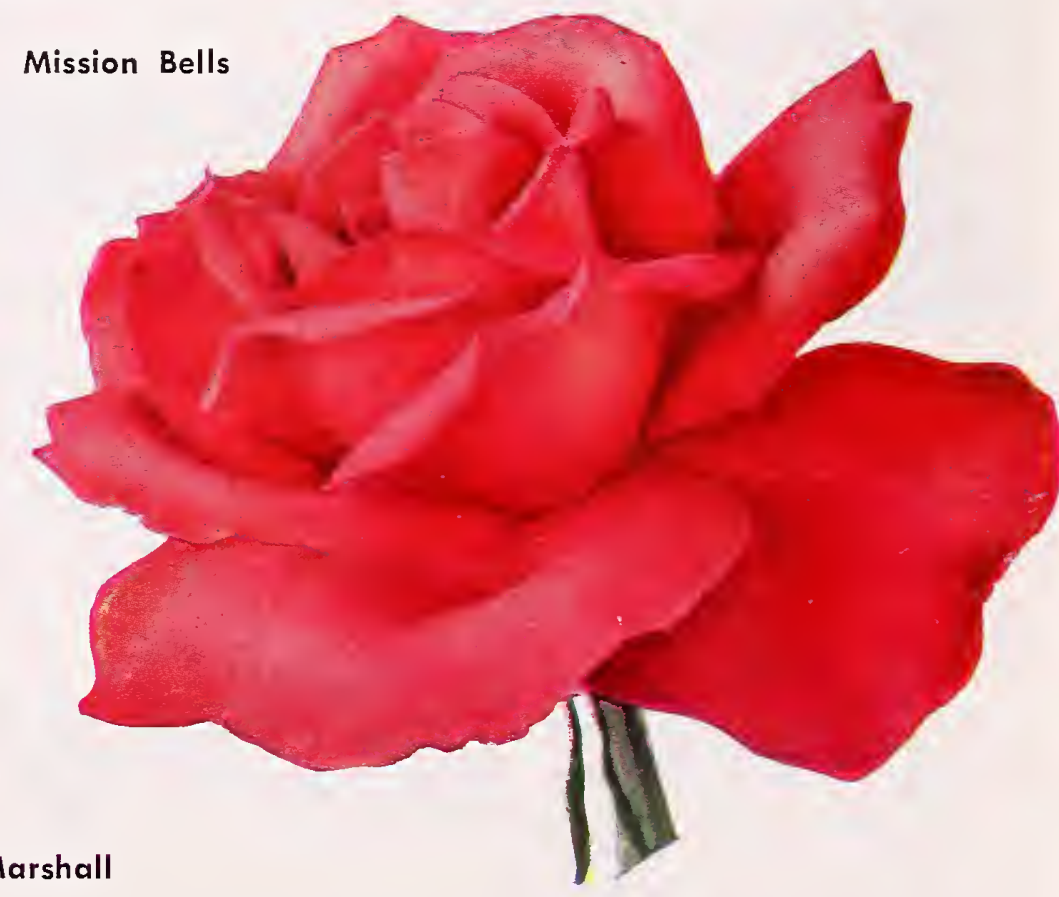

Katherine T. Marshall

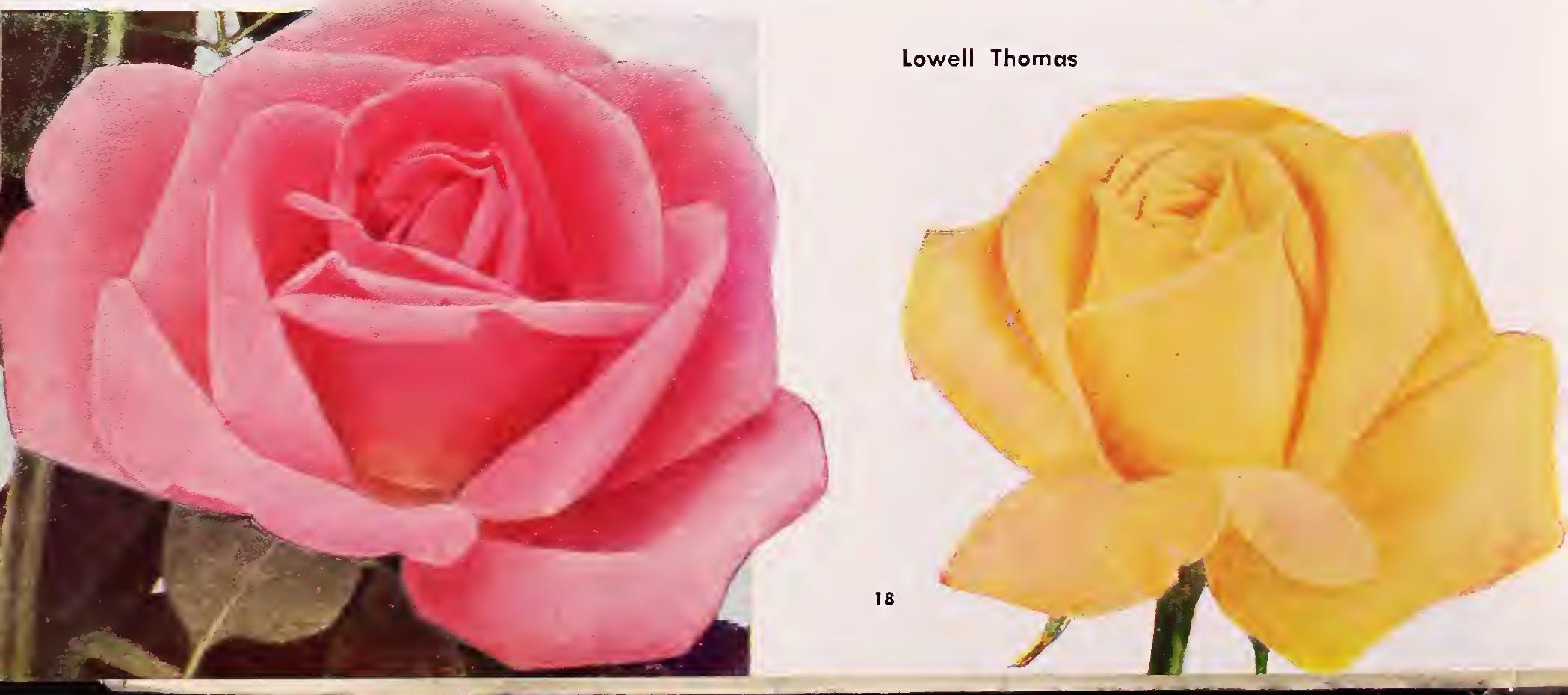




\section{Armstrong Bush Roses}

\section{Better Plants of the Best Varieties for You to Grow}

\section{President Herbert Hoover}

This popular old favorite is still considered by many planters to be one of the best multicolors. The long buds are beautifully formed and open slowly into gigantic blooms of cerise, pink, flame, scarlet, and yellow, which possess a most delicious fragrance. It is a magnificent grower, four feet in one season being quite ordinary, and it is not a question of how long you want the stems to be, it is only how long you wish to cut them. Give it plenty of room because it will use it. \$1.25 each; 3 or more, $\$ 1.10$ each.

\section{Rubaiyat}

The All-America Winner for 1947 , this Irish beaury produces a long shapely (1) bud of scintillating rose-red or crimson, usually becoming paler in the open A A R S bloom. Borh buds and flowers are extra large and carry a delighrful fragrance. This variety displays its best color and most perfect form in cool climates, but everywhere the tall vigorous plant keeps up a never-ending succession of blooms. Plant Pat. No. 758.

$\$ 1.75$ eoch; 3 or more, $\$ 1.55$ eoch.

\section{San Fernando}

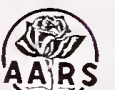

From over the Hollywood Hills in the sunny San Fernando Valley comes this fine All-America Selection for 1948. The perfectly shaped long buds are a rich currant-red, opening into fine, longlasting, unfading flowers ( 20 to 25 petals) of intense scarlet. A rich heady perfume adds to its charm. The vigorous plant is upright and well foliaged. Plant Pat. No. 785.

$\$ 1.75$ each; 3 or more, $\$ 1.55$ each.

\section{Sweet Sixteen}

Dainty pink, with tints of rose and a dash of gold-a soft rose complexion in the delicate colors of youth and beauty. The long, tight buds, half-open blooms and large flowers with 16 to 20 crisp petals are magnificent in their perfection. From spring until fall you will enjoy a long succession of sweetly fragrant buds and flowers borne on long straight stems. The plants are tall, rather slender and do especially well in coastal or cool weather regions, where Sweet Sixteen is exceedingly lovely in form and color. Plant Pat. No. 631.

$\$ 1.75$ each; 3 or more, $\$ 1.55$ eoch.

\section{Talisman}

This vividly colored rose is probably better known as a florist's cut flower than any other. The buds are exquisitely formed, orange-scarlet and golden-yellow in color, and are borne on long stiff stems. The open flowers are richly fragrant. Talisman was one of the very best roses of its day and it has great sentimental value for many planters. However, we think that Taffeta and other newer roses in this color range are superior.

$\$ 1.25$ each; 3 or more, $\$ 1.10$ eoch.

\section{The Chief}

(172) Large size and vigor are inherited (S) from its parent, President Hoover. AARS The gigantic bud of this All-America Winner for 1940 combines intense flame and copper tones, with the open flower showing flame, coral and copper. The fullblown flowers have a sweet fragrance, are fully double, and are at their best in warm weather. These long-stemmed beauties are borne on a spreading vigorous plant, to $41 / 2$ feet, which is resistant to mildew. Plant Pat. No. 456.

$\$ 1.75$ eoch; 3 or more, $\$ 1.55$ each.

The Chief

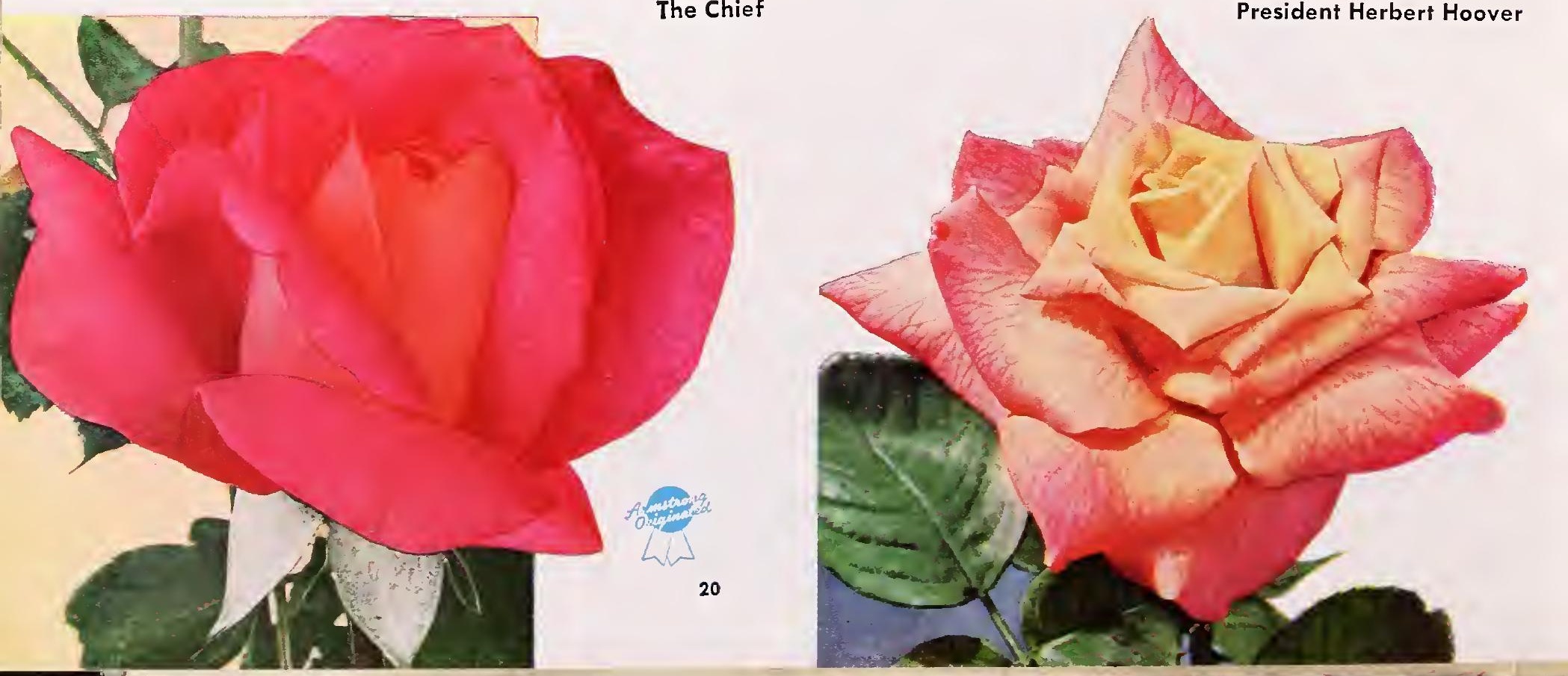



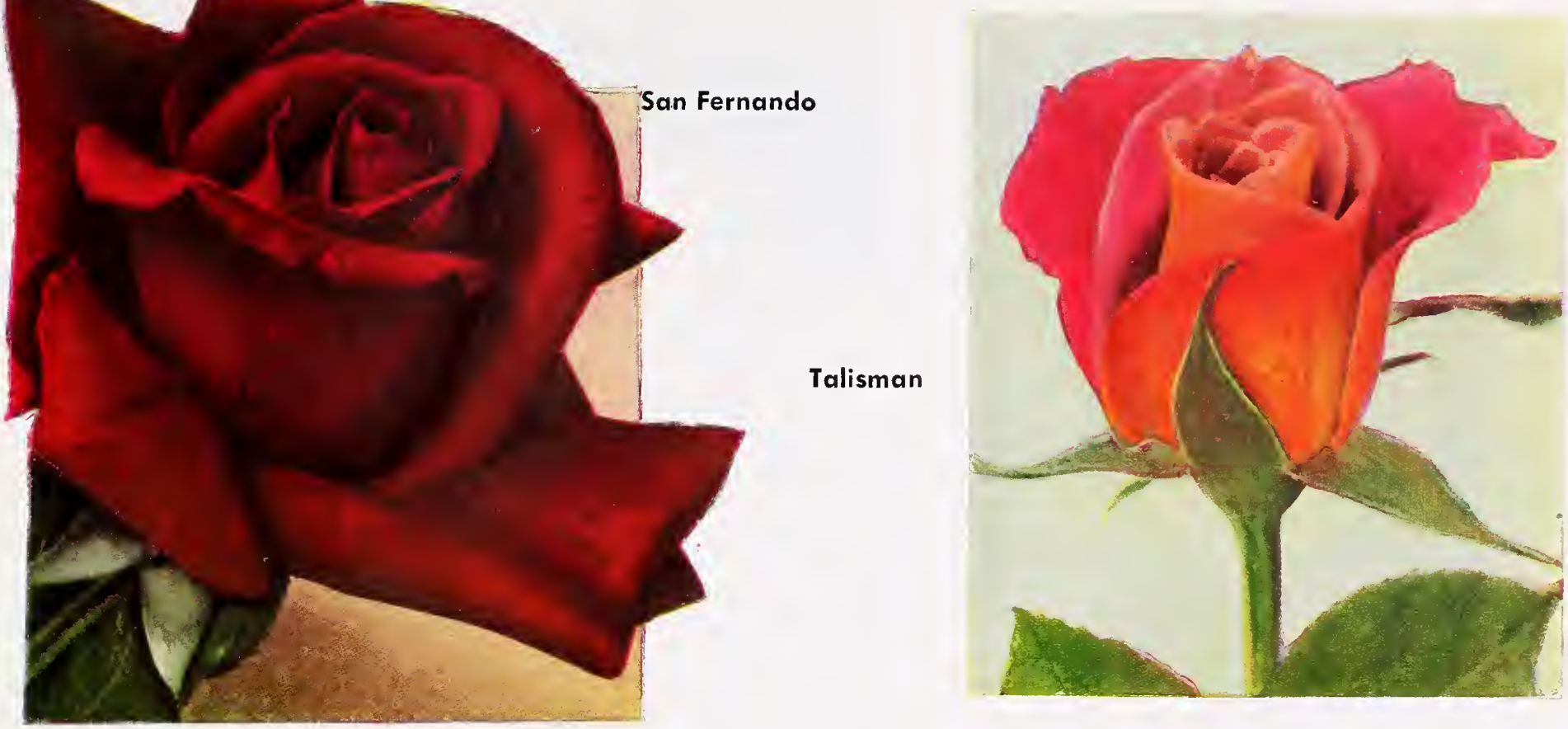

\section{Armstrong Bush Roses}

\section{The Best Standard Kinds From Everywhere}

True, many fine new and improved roses have been introduced in recent years, but the well-known varieties listed below are still favorites in many gardens. Space does not allow us a full color picture of every rose which we grow, but you may be sure that your order for the latest All-America Winners for 1952, or for the old-time Radiances will bring you a garden tested kind and a superbly grown Armstrong plant.

\section{Frau Karl Druschki}

Old though it is, "Frau Karl" is still one of the best of the whites. The long-pointed snow-white buds open to handsome flowers of immaculate white with plenty of big, substantial, waxy-textured petals. Give it lots of room, for the vigorous bush, with its handsome dark green foliage will sometimes grow as much as 6 feet in a single season! Does well everywhere.

$\$ 1.25$ each; 3 or more, $\$ 1.10$ each.

\section{K. A. Victoria}

K. A. Victoria has long been considered one of the best of white roses because it blooms so freely and continuously regardless of the weather Beautifully formed buds and magnificent, high-centered, fully double flowers of pure ivory white.

$\$ 1.50$ each; 3 or more, $\$ 1.30$ each.

\section{McGredy's Ivory}

The flowers of this Irish beauty are creamy ivory-white with the waxen petals turning to a clear snowy white as the flower opens. The buds are just about as perfect as any you will ever find and the graceful highcentered open flowers possess a delicate damask perfume. A vigorous plant of medium height with dark glossy foliage.

$\$ 1.25$ each; 3 or more, $\$ 1.10$ each.

\section{Radiance}

Under all conditions of soil or climate, this robust disease-resistant variety never fails. Popular for over 40 years because it never fails to give you plenty of beautiful silvery-pink fragrant flowers on extremely long, strong stems. $\$ 1.25$ each; 3 or more, $\$ 1.10$ each.

\section{Red Radiance}

Exactly the same as its sister, Radiance, except that the flowers are rich cerise-red.

$\$ 1.25$ each; 3 or more, $\$ 1.10$ each.

\section{Signora}

You seldom see this variety without breath-taking buds and wellformed flowers of intense scarlet-orange, shaded with tangerine and cerise. The fine robust plant produces very freely and no matter what the weather may be, each bud and flower is perfect-perfect in all stages. Plant Pat. No. 201 . \$1.75 each; 3 or more, \$1.55 each.

\section{Snowbird}

A small to medium sized rose, but one that is a real asset to any rose garden. Almost never is it without exquisite, long, flaring white buds and snowy, many-petaled, high-centered flowers. Our guess is that it will outbloom any other white rose in your garden by at least two to one.

$\$ 1.50$ each; 3 or more, $\$ 1.30$ each.

\section{Texas Centennial}

Often referred to as the "Red President Hoover." Just like that variety, it is an extremely tall, vigorous kind producing a plant 3 to 4 feet in height, with heavy strong stems and magnificent large full buds and flowers. The color is a bright glowing carmine red, fading to a softer rose-red as the flowers age. Give it plenty of room in your garden and then be prepared to pick some of the largest, most magnificent flowers you have ever seen. Plant Pat. No. 162.

$\$ 1.75$ each; 3 or more, $\$ 1.55$ each.

\section{No Matter Where You Live - You Can Enjoy Better Results With Armstrong Roses}

From North, South, East, and West, it's the same story. Each year thousands of rose planters everywhere in the country tell us that these big, husky, California-grown Armstrong plants grow more vigorously and bloom more freely than any plants they have received elsewhere. 


\section{THE FAMOUS \\ The Perfect Rose Garden}

For many years it has been our custom to select ten outstanding roses from our entire list and offer them as our now famous "Big 10." Each of the varieties in our Big 10 for 1952 is outstanding in its color class, and you will find every bush a typical Armstrong rose plant, husky and heavy-rooted.

Not only does ordering the Big 10 eliminate guesswork in choosing kinds for a super rose garden, but you save substantially over ordering the same roses individually. If you have room for only five plants, you can not choose five better kinds than the Armstrong-originated varieties pictured on this page and offered as the "All-A rmstrong Five.

\section{Nocturne Charlotte Armstrong}

This glorious All-America Winner with its long tapering blood red (10) buds and magnificent open flowers of cerise is the finest rose we grow. AAJR S See page 10. Plant Pat. No. 455 . \$2.00 each; 3 or more, $\$ 1.75$ each.

\section{Nocturne}

All-America Winner for 1948. With its long, perfectly formed buds and 17 big velvety dark red flowers, this is one of the finest of all red roses big velvety dark red flowers, this is one of the finst

\section{Debonair}

An outstanding yellow with jaunty, tightly furled buds and graceful, high-centered Anen flowers. A rich Mimosa Yellow with a delightful old-time rose fragrance. See page 14. Plant Pat. No. 677. \$1.75 each; 3 or more, $\$ 1.55$ each.

\section{Tallyho}

\section{Debonair}

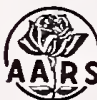

All-America Winner for 1949. The face of the petals is a delightful shade All-America of old rose, but the reverse is a brilliant cardinal red! In addition to its A.RS unique coloring, Tallyho features buds and fow rich spicy fragrance. See page 12. Plant Pat. No. 828 .

$\$ 2.00$ each; 3 or more, $\$ 1.75$ each.

\section{Sutter's Gold}

The most acclaimed rose introduction of 1950-All-America and Intera national Award Winner. An exceedingly vigorous plant which displays AARS perfect long yellow buds shot with orange, and big golden yellow flowers A.RS perfect lons Pat. No. 885 .

\section{All-Armstrong Five}

The complete "Big 10" will give you an outstanding rose garden, but if your space is limited, here are five of the best roses you can grow. One each of the Armstrong originations listed above will be sent postpaid at the proper planting time for only

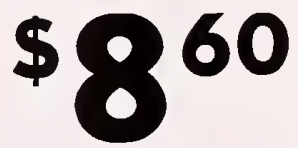
California orders, please add $3 \%$ sales tax.

Tallyho
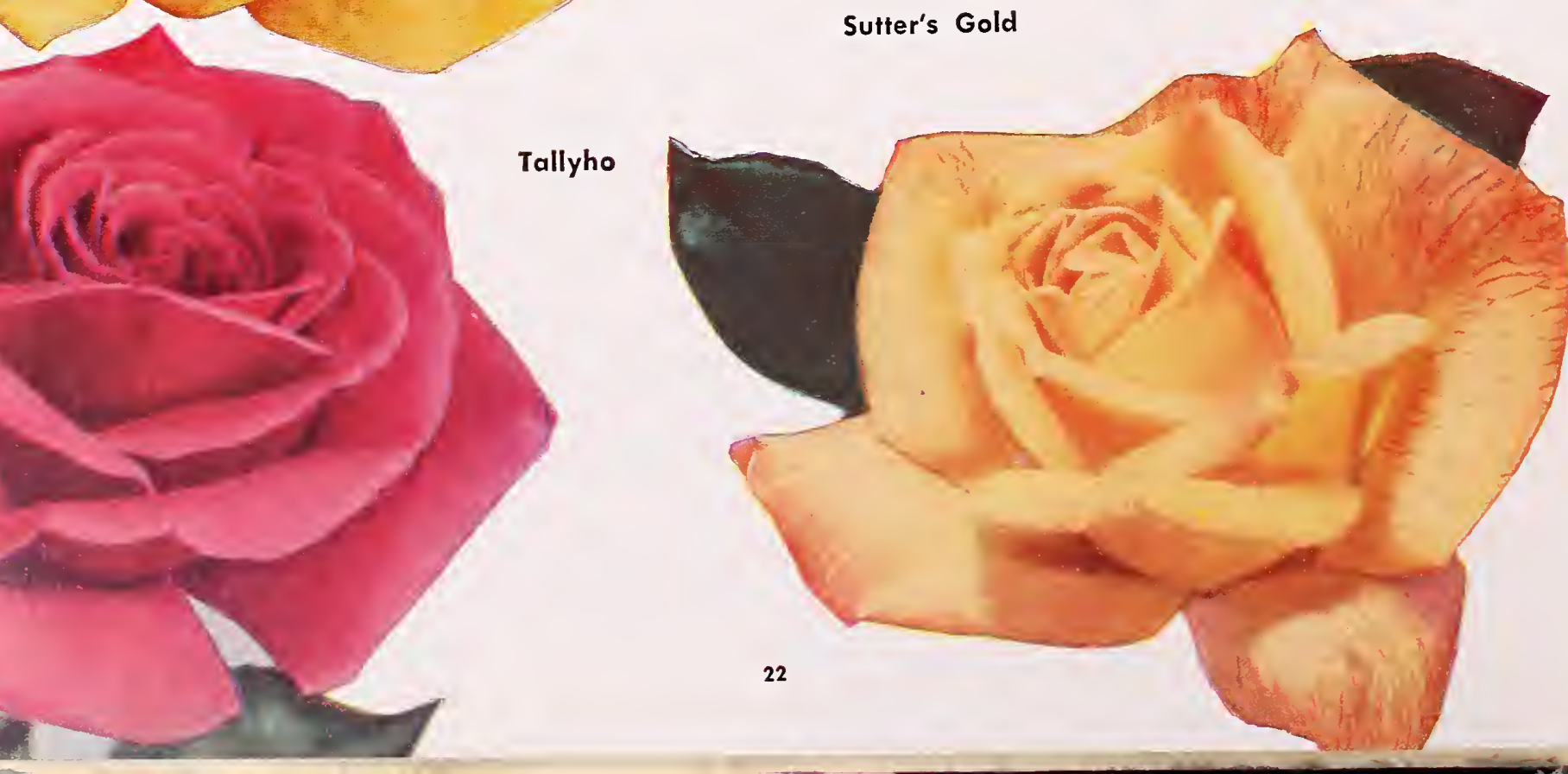


\section{ARMSTRONG BIG 10}

\section{Eclipse}

This is a rose well worth having in your garden if only to furnish you with bouquets of spicily fragrant, exquisitely beautiful buds. Of clear yellow, they are slender, urn-shaped, and often more than two inches long. The plant is a very vigorous one, rather erect in habit, and always well covered with dark green leathery foliage. Not all of the open flowers are as perfect as are the buds, but you'll overlook that when you see the many lovely buds, each one on a long, strong stem. Plant Pat. No. 172 . $\$ 1.75$ each; 3 or more, $\$ 1.55$ each.

\section{Fandango}

The gay orange-red buds and flowers atop the big strong plant will give you a more brilliant show of garden color, and do it over a longer time, than most any rose we know. See page 12. Plant Pat. No. 894.

$\$ 2.00$ each; 3 or more, $\$ 1.75$ each

\section{Peace}

No such amazing combination of strong stems, fine lasting qualities (10) and huge yet perfectly formed, delicately colored roses ever existed AAR S before. Perhaps the chief beauty of Peace is the great range of color through which it passes. The ovoid bud slowly opens to a glorious 5-inch bloom with shades of canary-yellow, pale gold, cream, pearly white, and apple blossom. Although the bloom is exceptionally large, double, and long-lasting, the dainty coloring makes it unusually lovely. The plant is vigorous and spreading. After winning the sole All-America Award for 1946, Peace has become one of the top roses in America today. Originated by Meilland (France). Plant Pat. No. 591.

$\$ 2.50$ each; 3 or more, $\$ 2.20$ each.

\section{First Love}

This Armstrong introduction for 1951 features long tapering urn-shaped buds of dawn-pink, just about as perfect as anything you have ever seen. See page 11 . Plant Pat. No. 921.

\section{Show Girl}

Undoubtedly this rose has the largest, yet most perfect buds to be found in rosedom. The big open flowers are mighty attractive too, and the bush is a big strong one which does well everywhere. See page 14. Plant Pat. No. 646.

$\$ 1.75$ each; 3 or more, $\$ 1.55$ each.

One each of the 10 varieties listed on these two pages 12 shipped anywhere in the United States postpaid at proper Dlanting time for only

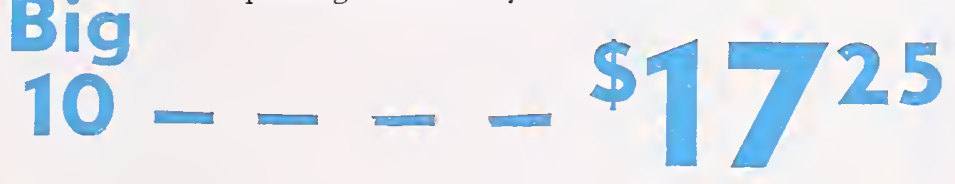

California orders add $3 \%$ sales tax.
Eclipse
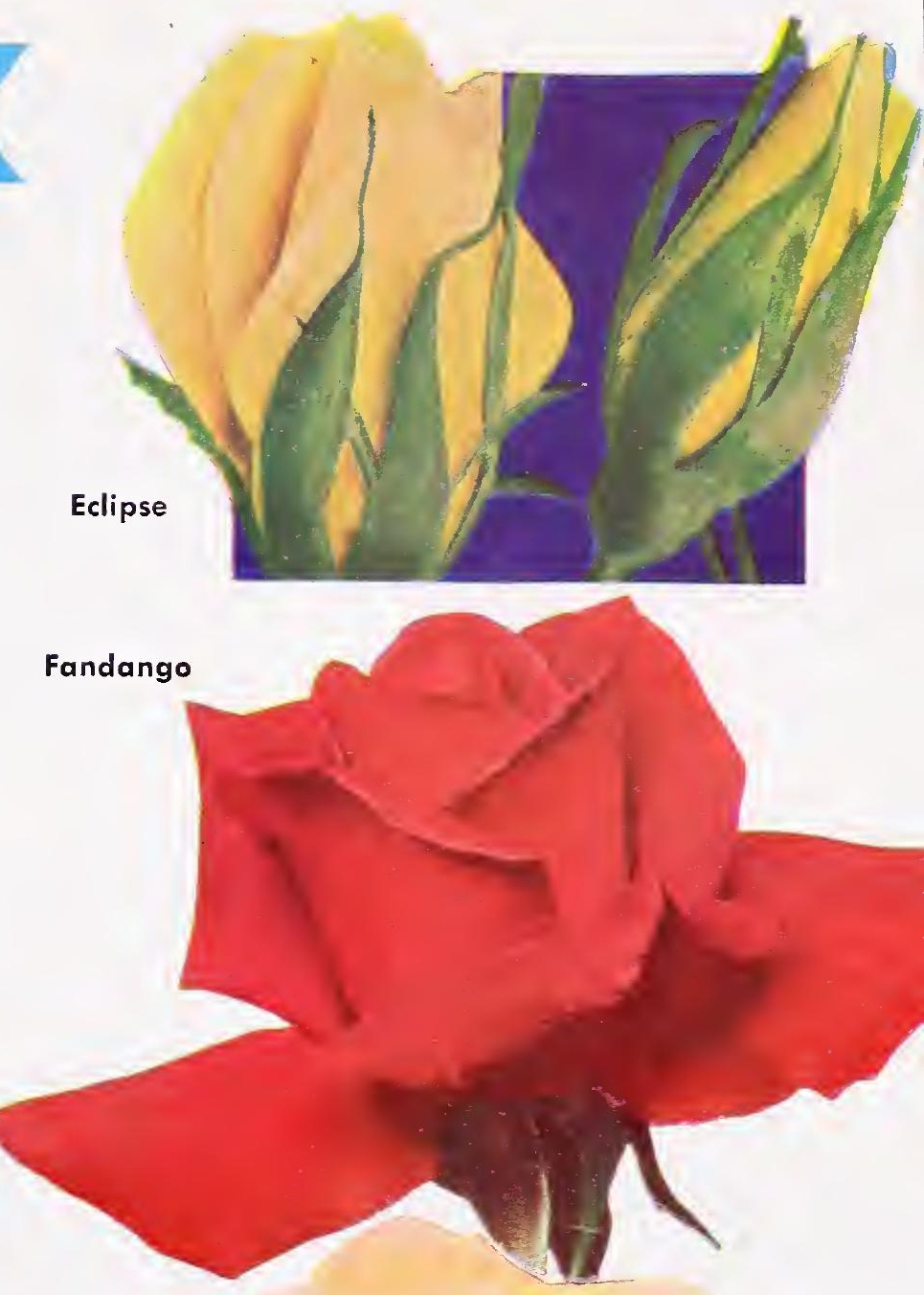

Peace

Show Girl

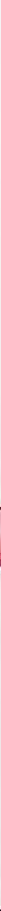




\section{Armstrong Tree Roses}

For lining walks or driveways or for lending the garden a touch of formality, few plants can equal the colorful tree roses. Standard, or tree-shaped roses are grown by budding the desired variety into a tall, straight stalk at a height of 36 inches. The bushy head often produces more flowers and larger ones than on the bush type of the same variety. The Floribunda tree roses are budded at a height of 24 inches and are perfect where a smaller tree is desirable.

\section{Shipped Bare Root}

During the months of January, February, and March, dormant bare root trees may be safely shipped for immediate planting to Pacific Coast areas, warmer sections of the Southern States, and portions of the East Coast. Because tree roses are extremely hard to handle, and because special costly cartons are required to make sure that you receive them in the same fine condition in which they leave our nursery, we make a $50 \mathrm{c}$ charge for packing and mailing each tree rose. During the summer and fall months some varieties of tree roses in full bloom are available in containers. See under "Roses in Containers," page 4.

Prices on all bare root, dormant Tree Roses, including Floribundas, $\$ 5.00$ each; $\$ 45.00$ per 10 . Ten assorted Tree Roses sold at the 10-rate. (Add 50c per tree for ship ping charges.)

\section{Bravo}

New for 1951. Huge perfect blooms of brilliant cardinal red.

\section{Charlotte Armstrong}

Beautiful long, streamlined buds of blood-red and brilliant cerise flowers. One of the world's finest roses.

\section{Debonair}

Exquisitely formed primrose-yellow buds and flowers.

\section{Fandango}

Lovely buds and breath-taking flowers of dazzling fiery orange-red. Blooms very early and continues to bloom freely.

\section{First Love}

The most perfect buds in rosedom-long, slender, and a delightful coral-pink in color.

\section{Forty-niner}

1949 All-America Winner. The most brilliant of bi-colors. Cardinal red with the reverse of the petals straw-yellow.

\section{Helen Traubel}

Brand new All-America Winner for 1952. Big perfect buds and fragrant flowers of luminous apricot, shading to warm pink.

\section{Lowell Thomas}

Rich golden yellow. One of the best of yellows for all areas.

Care is used in making every Armstrong Tree Rose a perfect garden specimen. Here is a view of a portion of our stock in the field

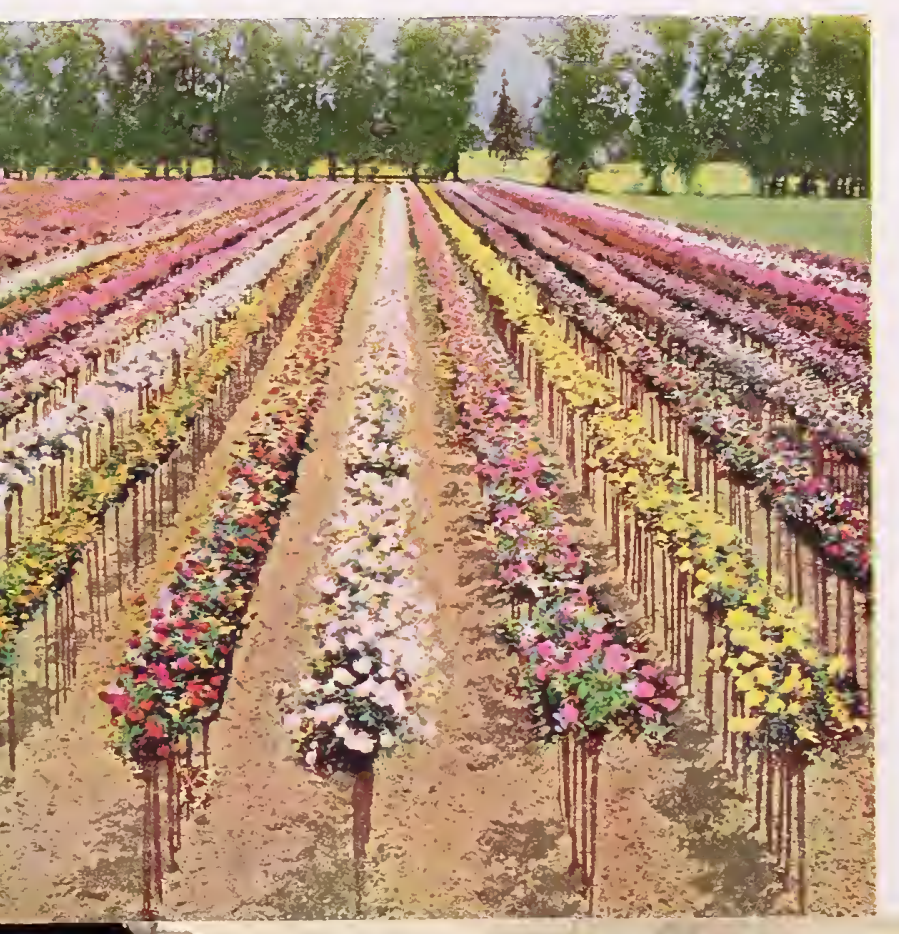

\section{Mirandy}

Glowing dark red buds and many-petaled flowers with a wealth of perfume. Magnificent warm weather rose.

\section{Nocturne}

1948 AARS Winner. Beautiful streamlined buds and glorious flowers of cardinal-red with darker shadings. Good everywhere.

\section{Peace}

1946 AARS Winner. Huge, yet perfectly formed and delicarely colored flowers of yellow, buff, cream, and appleblossom pink.

\section{Picture}

Sparkling, warm pink buds and open flowers in great profusion.

\section{Show Girl}

Great long buds of deep rose-pink. More than satisfying, it is a spectacular rose everywhere.

\section{Snowbird}

Beautifully shaped white buds open into snowy, many-petaled blooms loaded with fragrance.

\section{Sutter's Gold}

1950 AARS Winner. Perfect buds of yellow splashed with orange. Big, clear, golden-yellow flowers, richly fragrant. Very vigorous.

\section{Floribunda Tree Roses}

\section{on 24-Inch Stalks}

These many-flowered Floribundas budded on 24-inch stalks are something distinctive and unusual for your garden. No roses bloom more freely. As a rose garden border, or even as a single specimen, these diminutive tree roses are delightful. Wonderful as a potted or tubbed plant, too. See prices above.

\section{Fashion}

The unusual color, a blending of apricot and gold, has made this $1950 \mathrm{All}$ America Winner a top favorite everywhere.

\section{Goldilocks}

A cloud of dainty double flowers of clear yellow throughout the season.

\section{Pinkie}

The enormous quantities of petite, pink, perfectly formed buds and 2-inch open flowers will never cease to amaze you on a tree rose.

\section{Valentine}

This Armstrong creation is continuously covered with buds and semi-double flowers of rich dazzling crimson.

\section{Vogue}

All-America Winner for 1952. Plenty of bloom in a new color-cherry-coral. 


\section{Armstrong Climbing Roses}

Few garden plants will pay such generous dividends in beauty in return for ordinary care and a small space in your garden as climbing roses. Fences, trellises or arbors become aglow with color-bare walls and unsightly places are soon covered with masses of luxurious foliage, studded with hundreds of colorful blooms.

The Climbers we list here are a selected group of the world's finest. Most of them are climbing sports of famous Hybrid Teas which are outstanding for buds and flowers. In most of the Southern States and along the Pacific Coast they will thrive, but in regions of sub-zero temperatures, all except Paul's Scarlet will require special protection from cold damage.

All you have to do is give climbing roses an occasional watering and a bit of fertilizer in the late summer and early spring. They will never fail to reward you with literally thousands of beautiful roses every spring. Well grown climbing roses in the garden make the spring blooming season a matchless spectacle of color.

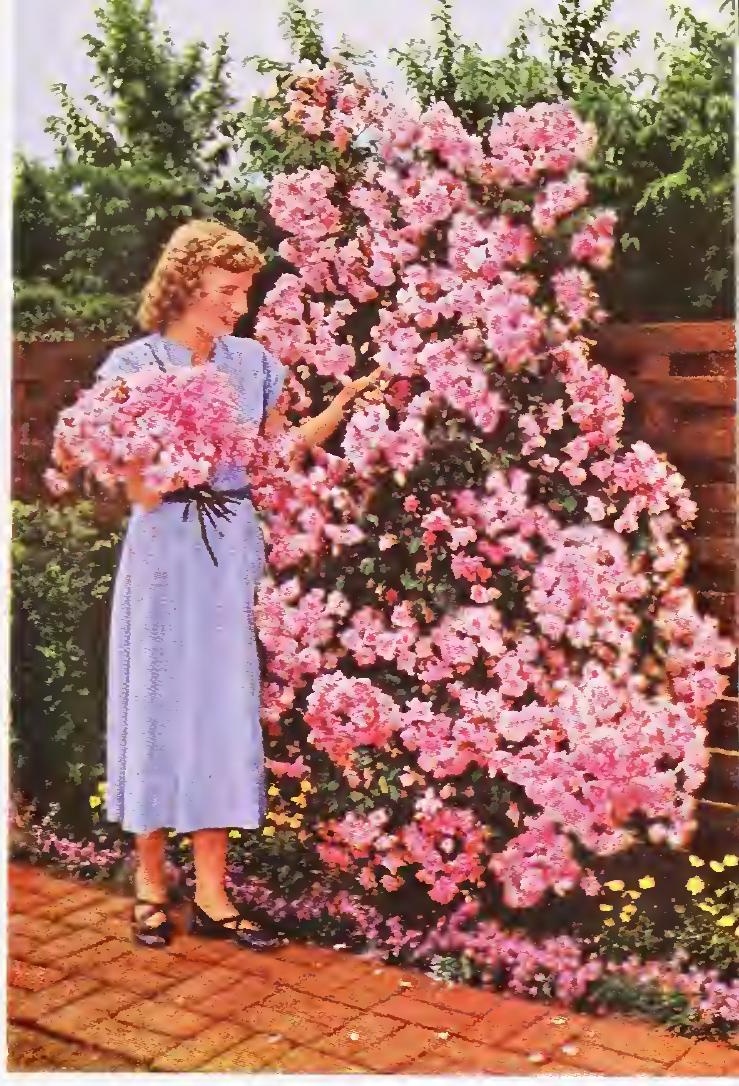

\section{Two Distinctive} New Climbing Roses Both Armstrong Creations

\section{Climbing Pinkie}

We know you will be delighted with it, just as we are, because the bushy yet compact 6 to 8 foot plant with its unbelievable masses of bloom is just right for many places where an ordinary climber would be too large. The glossy
The brilliant sunshiny yellow blooms of High Noon light green foliage is heavy and luxuriant, but in the spring you'll have to look hard to see it under the cloud of bloom. Just take a look at the picture above and you'll see what we mean. Every perfect little delicate pink bud and flower is spicily fragrant-just the same as those which won an AllAmerica Award for Pinkie in 1948. We've saved the best for last-in addition to all these features, this is a climber which doesn't stop with the first burst of bloom but keeps right on with cluster after cluster of dainty blooms throughout the season. You'll never want for flowers in the garden for cutting. Plant Pat. app. for. $\$ 2.75$ ea.; 3 or more, $\$ 2.40$ ea.

\section{New Everblooming Climber}

\section{High Noon}

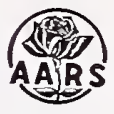

All of the concentrated brilliance of sunshine at midday is captured in the lovely buds of this extraordinary new climbing or pillar rose. The intense shade of clear shining yellow displayed in the medium-sized, well-shaped buds cannot be found in any other rose in the market today. It is not a rampant climber but is better described as a bushy 8 -foot pillar rose. Clothed with light green, glossy, mildew-proof foliage, it is fast growing and bushy, producing its many buds on long, almost thornless stems. Every brilliant little yellow bud is perfect for bud vase or buttonhole. In the spring High Noon becomes a gorgeous mass of brilliant bloom. But it does not stop there. It continues to produce additional bursts of bloom throughout the entire growing season. No other climbing rose will do this, and it is going to be one of the most popular climbers ever introduced for mild climates. High Noon was the Winner of a 1948 Regional All-America Award for the Pacific Coast and Southern States. It can be grown in colder climates if given proper winter protection. Originated in the Armstrong Research Dept. by W. E. Lammerts. Plant Pat. No. 704. $\$ 2.00$ ea.; 3 or more, $\$ 1.75$ ea.

Quantity rates apply to 3 or more plants of the same variety only. 


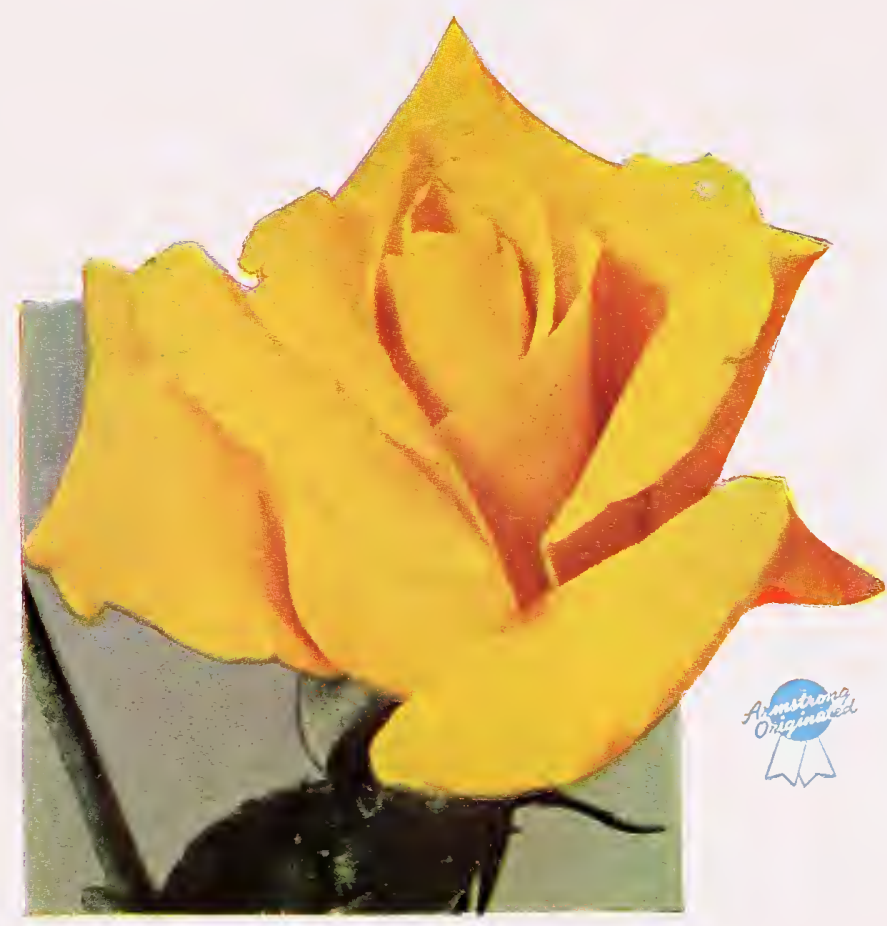

Climbing Golden Rapture

\section{Belle of Portugal}

In early spring before other roses are in bloom, this very vigorous climber (10 to 12 feet in a season is not unusual) will be studded with amazingly beautiful salmon-pink buds which are gigantic in size, often 3 or 4 inches in length. It is too busy growing to bloom the first season after planting, but be prepared for spectacular masses of bloom from then on

$\$ 1.50$ each; 3 or more, $\$ 1.30$ each.

\section{Billy Boiler}

We believe this variety has the most perfect non-fading blooms of any red climber. The robust, many-caned plant grows to 12 feet, and on great long stems for cutting are immense perfect flowers. Deep red, with blackish shading and quite double, the blooms are deliciously fragrant.

$$
\$ 1.50 \text { each; } 3 \text { or mare, } \$ 1.30 \text { each. }
$$

\section{The Charming Cherokees}

We like these old-fashioned single-flowered roses because they fit into in formal landscapes so well and are at their best when allowed to ramble over a fence or wall without pruning. The foliage is shiny green and the delicate flowers are produced in great masses in the spring. We have Pink Cherokee, Red Cberokee and White Cherokee. $\$ 1.75$ each; 3 ar mare, \$1.55 each.

Brilliant Paul's Scarlet

\section{Climbing Cecile Brunner}

Few roses can equal the continuous show of dainty, little, rose-pink, salmon-shaded buds in clusters produced by this famous old Polyanthus. One of America's favorites, it is a strong grower and needs no special coaxing. $\$ 1.75$ each; 3 ar mare, $\$ 1.55$ each.

\section{Climbing Dainty Bess}

Everyone likes the dainty, single, suntanpink flowers of the bush Dainty Bess. Imagine having a large climbing plant of that beautiful variety covered with hundreds of long-stemmed blooms in the spring instead of just a few. You can cut an armful of them most any day in spring and still have plenty left. $\$ 1.50$ each; 3 ar mare, $\$ 1.30$ each.

\section{Climbing Christopher Stone}

The big velvety red flowers with their waxy petals and delicious perfume which are so admired on the bush form of Christopher Stone can now be had on a climbing plant It will transform an arbor or trellis into a gorgeous springtime spectacle. Plant Pat. No. 626. \$1.75 each; 3 ar mare, \$1.55 each.

\section{Climbing Etoile de Hollande}

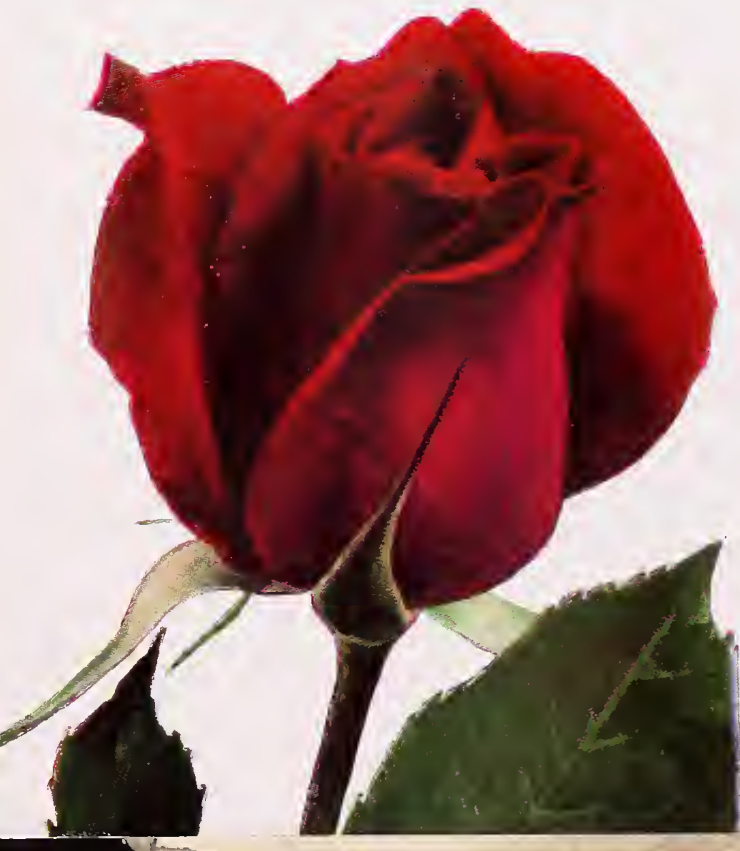

Climbing Etoile de Hollande

Some of the finest big red buds and open flowers that we have ever seen are produced on this big, strong growing plant with its attractive great big fresh looking foliage. Actually the blooms are of ten larger and on longer stems than those of the bush Etoile de Hollande and they possess the same rich fragrance. We rate it as the finest red climbing rose that we grow and there are seldom enough plants to supply the demand because it is a difficult kind to propagate.

$\$ 1.75$ each; 3 ar mare, $\$ 1.55$ each.

\section{Climbing Golden Rapture}

This glorious, rich, shining, yellow rose is fast becoming a favorite with rose growers everywhere. Not only will it produce hundreds of magnificent blooms in the spring, each one catching and reflecting the golden sunshine, but you can cut hundreds of longstemmed beautifully formed buds and open flowers, and take that sunshine right into your house. Plant Pat. No. 508.

$\$ 1.75$ each; 3 ar mare, \$1.55 each.

During the summer manths many of these climbers are available as blooming (3-yearald) plants in 5-gallan cantainers at increased cast. Get them at any Armstrang Salesyard. Because af their weight and bulk, it is nat practical ta ship them.

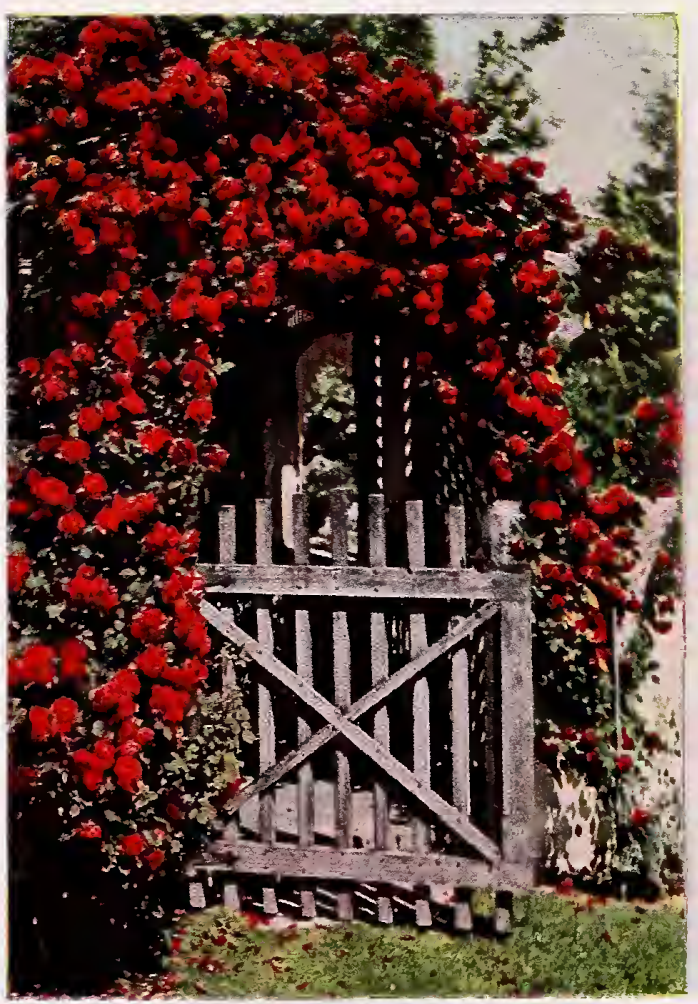

\section{Climbing Golden Dawn}

Graceful buds of sunflower-yellow opening to big fully double flowers of lemon-yellow literally cover this handsomely foliaged plant in the springtime. Unlike most climbers it will produce richly fragrant flowers right up to the late fall. Plant Pat. No. 243.

\section{Climbing Hinrich Gaede}

$\$ 1.75$ each; 3 ar mare, $\$ 1.55$ each.

It is difficult to decribe the brilliant fame-like combination of orange and vermilion which give these flowers so much richness and beauty. This Armstrong introduction will not only bloom in the spring but will produce occasional blooms all through the summer. Plant Pat. No. 244. $\$ 1.75$ each; 3 ar mare, $\$ 1.55$ each.

\section{Climbing K. A. Victoria}

K. A. Victoria has long been a favorite because of the free and continuous blooms which it producs. This climging sport gives you plenty of those same beautifully formed ivorywhite buds and

\section{Climbing McGredy's Ivory}

$\$ 1.75$ each; 3 ar mare, $\$ 1.55$ each.

This variety is the answer to those who want a large-flowered white. In the spring this climber is covered with dozens of exquisite ivory-white buds which open to deliciously fragrant, big, snowy flowers which you will enjoy cutting. \$1.75 each; 3 ar more, $\$ 1.55$ each. 


\section{Planting Guide - What \& Where to Plant}

\section{Plants for Desert Areas}

Here is a list of shrubs, trees and vines suited to Arizona and the dry desert sections of California. If you are in the northern part of this area or at high altitudes, check minimum temperatures given in each description. Page numbers given below.

Abelia grandiflora.... 40 Arborvitaes ............6 65 Arctotis ......... 66 Australian Fuchsia.- 41 Big Yellow Spanish Blue Chaste Tree.... Bottle Brush 42 Buddleias ......-.-.-.-. 41 California Holly...... 53 Canary Island

Lupine ............... 40

Chinese Hat Plant...-. Cotoneasters ....

Cypress ……

Desert Willow

Euonymus P...-

54

Firethorn 53

Flo. Crabapple.......... 69

Flowering Quince... 70

Giant Matilija Poppy 54

Geraldton $\mathrm{Wax}$

Glower

Japanese Boxwood...- 41

asmine …..........50-62

Lantana

Lippia

Mexican Mallow

Meyer Lemo

Murtles

Nandina

Natal Plum

Oleanders

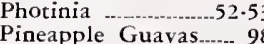

Pittosporum -...-... 53

Privet

Rockrose

Rosemary

San Diego Fremontia 46

Shasta Daisy..

Silver and Blue
Germander .......... 55

Silver and Gold

Daisy Bush

Spreading Savin

Juniper

Strawberry Tree........ 40

Tea Tree.......... 51

Thyme

Trinidad Flame Bush 42

Winter Creeper 100

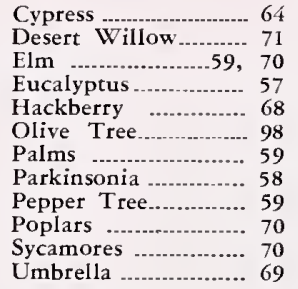

Vines

Climbing Syringa.

Fig Vine......

Orange-Red

Queen's W reath.

Roses, Climbing.-.

Silver Lace Vine

Star Jasmin

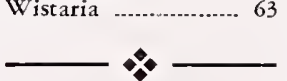

\section{Fragrant} Plants

Bouvardias ............ $41 \quad \begin{gathered}\text { Fragrant Corsage } \\ \text { Plant }\end{gathered}$

Breath of Heaven.... 44

Buddleias

Calamondin

Cassias.

Ceanothus

Climbing Syringa

Daphnes

Deciduous Magnolia

Evergreen Pear.

Fragrant Corsage

\section{Gardenias}

Giorybower

Glorybowe

Honey Coronilla

Honeysuckles

Lemon

Lilacs -.......
Mexican Orange.

Natal Plum.--

Jessamine

Osmanthus

Passion Fruit

Pink Lemon

Pittosporums

Royal Trumpet

Roses _..._............... 2-29

Silver Lace Vine

Chinese Plumbago

Japanese Anemone.... 66

Oregon Grape

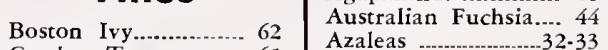

Catclaw Trumpet

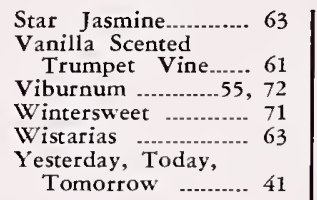

\section{Fragrant Trees}

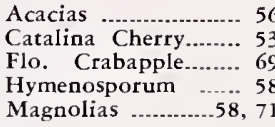

\section{Plants for Shady Places}

Abelias ................... 40

Barberr

Bergenia cordifolia.

Boxwood

Cape Honeysuckle

Catalina Cherry...

Daphnes

Dwarf Blue

Eranthemum

Escallonia

Eugenias

Evergreen Pear.

Fern Pine.

Ferns

nt Carpent

Fuchsias

Ginger Lily

Glossy Leaved

Grand Duke

Jasmine .

Holly ...................

Hydrangea .......... 48

Junipers ................. 64

Maidenhair Fern...... 48

Myrtle

Nandina -..-.....-........

Night Bloomi

Osmanthus

Pittosporum

Plumbag

Reinwardtia indica.- 67

Rondeletia

Rose Glorybower...

Serbian Bellflower

Star Magnolia

Strawberry Tree
Iris Moraea.....-....... 67

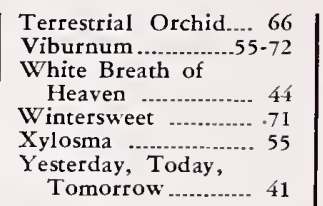

Korean Spice

Viburnum
Lantanas

Magnolias

Mexican Mallow..

Oleanders

Pelargoniums

Poinsettias

Princess Flower

Red Flo. Maple.

\section{Seashore}

Plants

Australian Bluebell

Creeper

Brazil Skyflow'

Cape Honeysuckle

45
63

Distictis

Escallonias

Eugenias

Frame Vine.....--

Geraniums

Hibiscus

Lippia

Myoporum Iaetum

Myrtle

Natal PIum -..--.--

Night Blooming

Jessamin

Pittosporum

Plumbago

Pride of Madeira.

Privets

Rockrose

Rosemary

Scarlet Bottle Brush

Silverberry

Sky Flow

Trumpet Vines.... 5

Bottle Tree.......-..... 56

Cottonwood ........... 70

Red Lantern Plant.. 51

Reinwardtia ........... 67
Royal Trumpet....... 61

Salvia ..............

San Clemente

Snapdragon

Skyflower

South African

Daisy Bush.

Star Magnoli

Tea Trees.

Trailing Lantana

Trumpet Vines $60-6$

Weigela

Wintersweet

Yesterday, Today,

\section{For Pots, Tubs} or Planters

Acanthus Bird of Paradise...... 5

Calamondin Citrus........

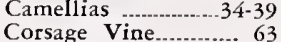

Corsage Vine.........

Fatshedera

Fatsia

Fuchsias

Gardenias

Geraniums

Gold Dust Plant.

Ivy _..............................

Kumquat

Marguerites

Meyer Lemon

Larger Plants for

Background or Screens

California Holly...... 53 California Lilacs....... 42

Carolina Laurel

Cherr

Catalina Cherry.

Chinese Hat Plant

Cocculus

Cotoneasters

Eugenia

Evergreen Pear...

Firethorn

Hibiscus

Holly Leaf Cherry.-.

Holly Leaf

Sweetspire

\section{Number Plants to Acre}

Distance Apart

No. Plants

Ft. Apart

Oranges, Lemons

18 to 25
25 to 35

Avocados

Walnuts and Pecans ...-...................40 to 60

Olives .................................................... 30 to

Jujubes, Low-Pruned Figs ...............12 to 16

Grape Vines ................................. 6 to 8

Blackberries, Boysenberries ............ 6 to 8

Raspberries ................................ 3 by 5

Strawberries .............................1 $1 / 2$ by 3

Eucalyptus for Windbreak............... 4 to 8
8 feet by 10 feet

16 feet by 16 feet

170

18 feet by 18 feet

20 feet

90

25 feet by 25 feet

30 feet by 30 feet.

40 feet by 40 feet 27

50 feet by 50 feet.

Azaleas -.o. 32-33 


\section{Armstrong}

More and more, azaleas are becoming indispensable in the gardens of the Pacific Coast and the South because of their glorious display of spring color and the attractiveness of the plant with its shining evergreen foliage throughout the rest of the year. They may be had in a wide range of delightful colors, from snowy white through pastel shades of lavender, pink, rose, and salmon, to vivid oranges and fiery reds. Even single plants are effective, but a grouping of plants and the use of several colors in a mass planting will create a truly spectacular feature in any garden.

How to Grow Them The plants of all the varieties we list are relatively hardy and can be grown successfully all along the Pacific Coast and throughout the South, except in the hot dry areas. In the Northwest and the Southern States and in the central and northern coastal areas of California, the natural soil conditions make azalea culture easy. However, in most of southern and inland California the usually alkaline soil must be mixed with liberal quantities of peat moss or leaf mold. Peat moss is excellent. It not only makes the soil more acid, holds moisture extremely well, but at the same time allows good drainage. These conditions are requirements for growing good azaleas. The plants prefer full shade or semi-shade and do particularly well under trees where they can be well fertilized and given plenty of water. An occasional application of acid food will tend to keep the soil acid and the plants vigorous and healthy. We send detailed planting instructions with every order.

Shipping Weights 6-inch pots, approximately 3 lbs.; 9-inch pots, about 8 lbs.; large specimens in tubs, about $50 \mathrm{lbs}$., packed for shipment.

\section{Azalea Rutherfordiana}

Purity-a large-flowered Rutherfordiana Azalea

\section{Plont Pat. Nos. $145,146,147$}

These magnificent hybrids combine all of the desirable characteristics found in azaleas. The flowers are very large and the bloom so profuse that you are often unable to see the foliage during the blooming season. The handsome 2 to $4-\mathrm{ft}$. plant is evergreen and perfectly hardy to zero. Flower buds, however, may be damaged if temperatures go below $23^{\circ}$.

All varieties, blooming size, 6 -inch pots, $\$ 3.50$; 9 -inch pots, $\$ 6.00$

lorge specimens of some vorieties in tubs, $\$ 15.00$ each.
Albion This azalea is the most fragrant of any variety we grow. The snowy-white semi-double flowers come late and are usually at their best during the Easter season.

3675-6-inch pots. 3676-9-inch pots.

Constance Deep lavender-pink, paling to a light creamy pink at the center. Single. A handsome foliaged, compact plant. Blooms early to midseason. $3680-6$-inch pots. $3681-9$-inch pots.

Dorothy Gish Brick-red with rich red markings on the throat. A popular early to midseason bloomer with hundreds of showy semidouble flowers covering a compact plant.

3685-6-inch pots. $3686-9$-inch pots.

Firelight Bright cherry-red with markings of currant-red. The mildly fragrant flowers have two rows of gracefully ruffled petals. The large tall growing plant blooms early. Big, broad, glossy foliage. $\quad 3690-6$-inch pots 3691-9-inch pots.

L. J. Bobbink One of the largest of the Rutherfordiana Azaleas. The big, semi-double blooms are a lovely lilac color, and have a delightful fragrance. Blooms late in the spring.

3695-6-inch pots. 3696-9-inch pots.

\section{For Christmas . . \\ For Easter . . \\ Any Occasion . .}

\section{Beautiful Living Bouquets}

Instead of sending holiday or special occasion bouquets, just try an azalea plant in full bloom all done up in fancy wrappings. It will make a long remembered gift because the bloom will be enjoyed for a long while and then the plant can be set out in the garden to bloom again year after year.

From mid-December until after Easter you can get beautiful big azalea plants in full bloom and have them attractively gift-wrapped at any of our five salesyards.

\section{See Them in Bloom}

This is an invitation to visit any one of our five Southern California salesyards at azalea time-the late winter and early spring months. We know you will enjoy seeing for yourself what a spectacular show of color azaleas make. Thousands of them in full bloom is a sight worth seeing.
Purity Large, pure white blooms; quite fragrant; 2 rows of petals. Gives you lots of early spring bloom. With Purity and Albion both in your azalea garden you will have beautiful white flowers during the entire blooming season. $3705-6$-inch pots. $3706-9$-inch pots.

Rose Queen The flowers of this variety have the brightest pink shade of any azalea on our entire list. Rose Queen blooms early, has large, double, deep rose-pink flowers that are slightly fragrant. An exceedingly heavy bloomer. $3710-6$-inch pots. 3711-9-inch pots.

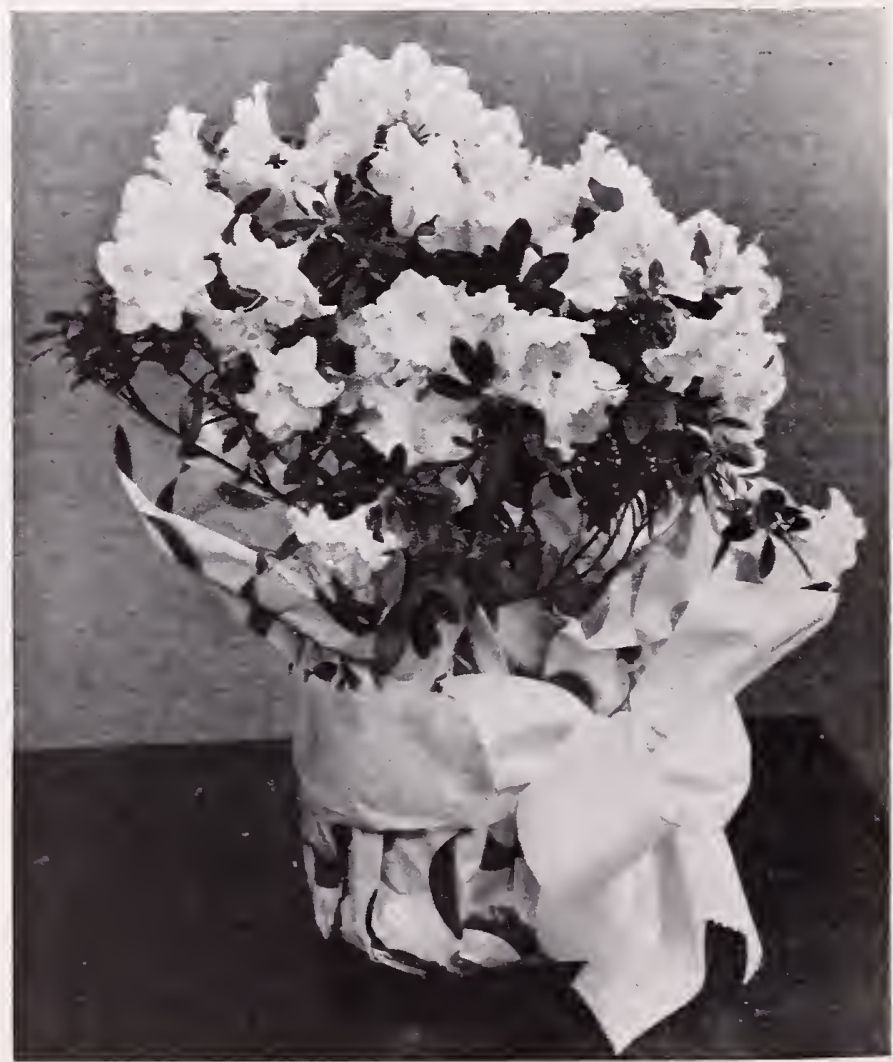




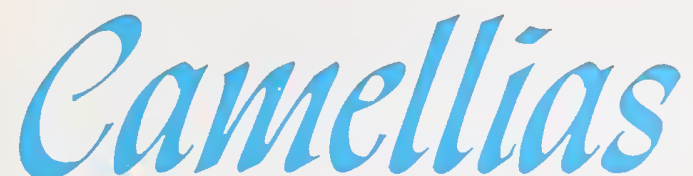

\section{M. Hovey (Colonel Firey)}

Beautifully shaped flowers up to 5 inches across of glowing rich crimson or cherry-red. The many petals open to a broad, flat, formal double bloom, lovely in form, with the color rich and glowing. The plant is fairly slow growing, about as broad as it is high. Blooms late.

$$
\text { 3970-Gcl. tins, } \$ 3.00 \text {. 3971-5-gal. tins, } \$ 9.50 \text {. }
$$

\section{Cameo Pink}

A new variety similar to the ever popular Pink Perfection in size, form and color. The flowers, $21 / 2$ to 3 inches across, of delicate rose-pink, are formal and fully double, occasionally showing a slightly irregular rosette-like center. Their perfect size and dainty coloring make them an ideal corsage flower. The plant is handsome with big dark green foliage and seems to hold its buds better than Pink Perfection. Blooms early mid-season. 3980-Gal. tins, \$3.50. 3981-5-gal. tins, $\$ 12.00$.

\section{Candida Elegantissima}

The color illustration below cannot picture the bright cheerful shade of pink which this camellia possesses. The flowers are very large, 4 to 6 inches across, semi-double, with very large, ruffled petals of bright rose-pink, heavily marbled with white. We consider it one of the finest camellias of its type because of the clarity of its color, its size, and keeping qualities. The plant is vigorous, upright, with large lustrous foliage, every bud opening into a perfect bloom. Midseason. $\quad 3990-$ Gal. tins, $\$ 3.00$. 3991-5-gal. tins, $\$ 9.50$.

\section{Cheerio Aluays a Surprise}

You may get four distinctly different colored flowers on one plant of Cheerio. (1) Sometimes solid pink, (2) pure white, (3) half red and half white, (4) but most often white profusely striped with red. No matter which color you get, you'll have a beautiful bloom, perfect in every way. The flowers are broad-petaled, semi-double, of average size, on an upright, bushy plant. Each flower just right for dish display indoors. Midseason.

$$
\text { 4005-Gal. tins, } \$ 3.50 \text {. }
$$

4006-5-gal. tins, $\$ 12.00$.

\section{Covina}

A tall, compact, vigorous plant and a tremendous producer of medium sized, semi-double, clear rose-pink blooms which open over a long period. One of the easiest of all camellia varieties to grow. Blooms midseason. $\quad 4010-$ Gal. tins, $\$ 2.25$. 4011-5-gal. tins, $\$ 7.50$.

\section{Daikagura Earliest to Bloom}

Its large double flowers of loose peony form, deep rose pink (sometimes blotched with white) would be beautiful at any season, but are doubly valuable because this is one of the first camellias to bloom. From early October through December even very young plants are often loaded with very large, well-developed flowers. The plant grows rather slowly and has an open willowy habit. $4030-$ Gal. tins, $\$ 3.50$

4031-5-gal. tins, $\$ 12.00$.

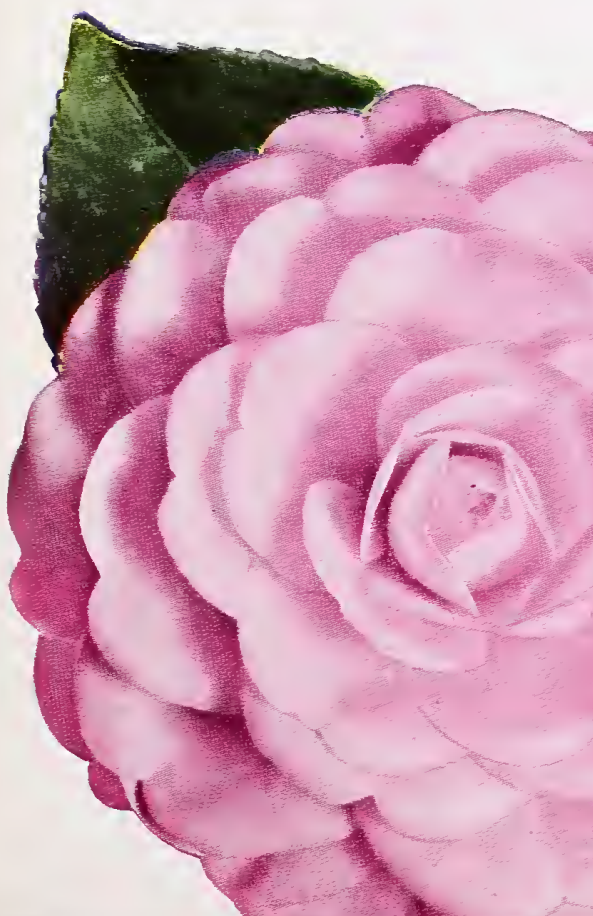

The new Eleanor Hagood loveliest of pinks

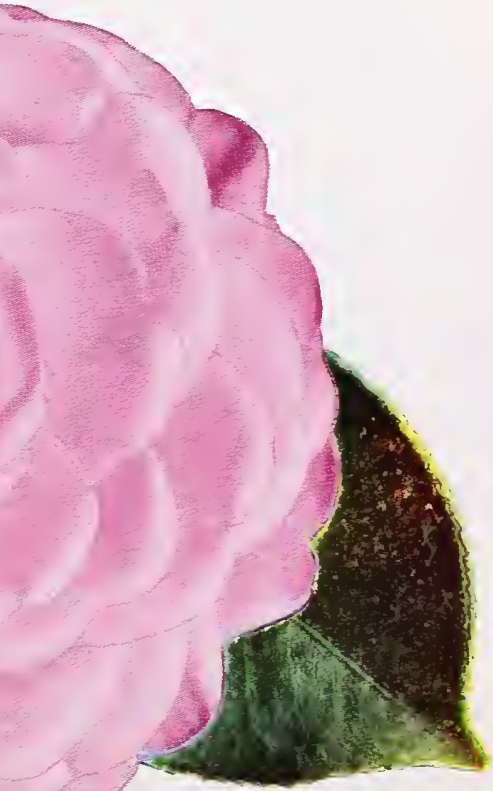

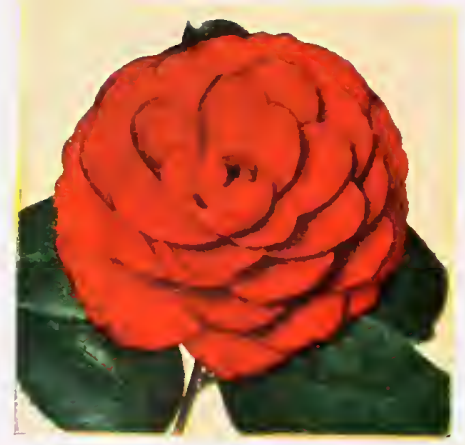

C. M. Hovey

\section{Debutante The Perfect Corsage Flower}

This lovely shell-pink camellia has already become one of the most popular of all varieties wherever camellias are grown because of the charm of its delicate soft coloring and its graceful pleasing form. For corsage or flower arrangement or just to admire on the plant, Debutante captures the affection of everyone who sees it. The plant is exceptionally vigorous, growing with great rapidity, and it freely produces many of the stunning pink flowers which appear quite early in the season. 4050-Gal. tins, \$3.50. 4051-5-gal. tins, $\$ 12.00$.

\section{Eleanor Hagood New, Rare, Lovely}

Regardless of how many adjectives we may use, it is impossible to adequately describe the appealing beauty of Eleanor Hagood. We believe it is the finest variety of its form and color. When more planters become acquainted with it, it will unquestionably be one of the most popular of camellia varieties. The large flower, 4 to 5 inches across, is fully double, with petals arranged formally in imbricated style. The petals are larger at the outside, diminishing in size to small petals in the center. The color is a delightful shade of clear soft pink. It is a perfect cut flower for corsage or bowl arrangements. The plant is vigorous, large-foliaged and bushy, growing rapidly, and blooming freely. It never drops its buds. We can guarantee that you will enthuse over the blooms when you get them. Blooms rather late. $\quad 4070-$ Gal. tins, $\$ 4.25$. 4071-5-gal. tins, $\$ 15.00$

\section{Elegans (Chandler)}

One of the largest and most spectacular of all camellias. The great 6-inch rose-pink flowers, lightly splashed with white, will astonish you with their size and beauty. The slow-growing, comparatively dwarf plant produces its gigantic beautifully colored blooms in great profusion, setting an amazing number of buds even on very smal plants. The anenone-formed flower is a wonderful cut bloom for bowl or corsage. Blooms early to midseason.

$$
4080-\text { Gal. tins, } \$ 3.50 \text {. } 4081-5 \text {-gal. tins, } \$ 12.00 \text {. }
$$

\section{Elena Nobile}

An uncommon variety, outstanding because of the extraordinarily rich color of the blooms-dazzling flame-red, almost the color of poinsettias. The medium sized semi-double blooms keep well after cutting and are splendid for corsage or bowl. A vigorous, upright, bushy plant. Blooms late, after most kinds are gone. $4090-$ Gal. tins, $\$ 3.00$. $4091-5$-gal. tins, $\$ 9.50$

\section{Candida Elegantissima 4 to 6 inches across and always perfect}

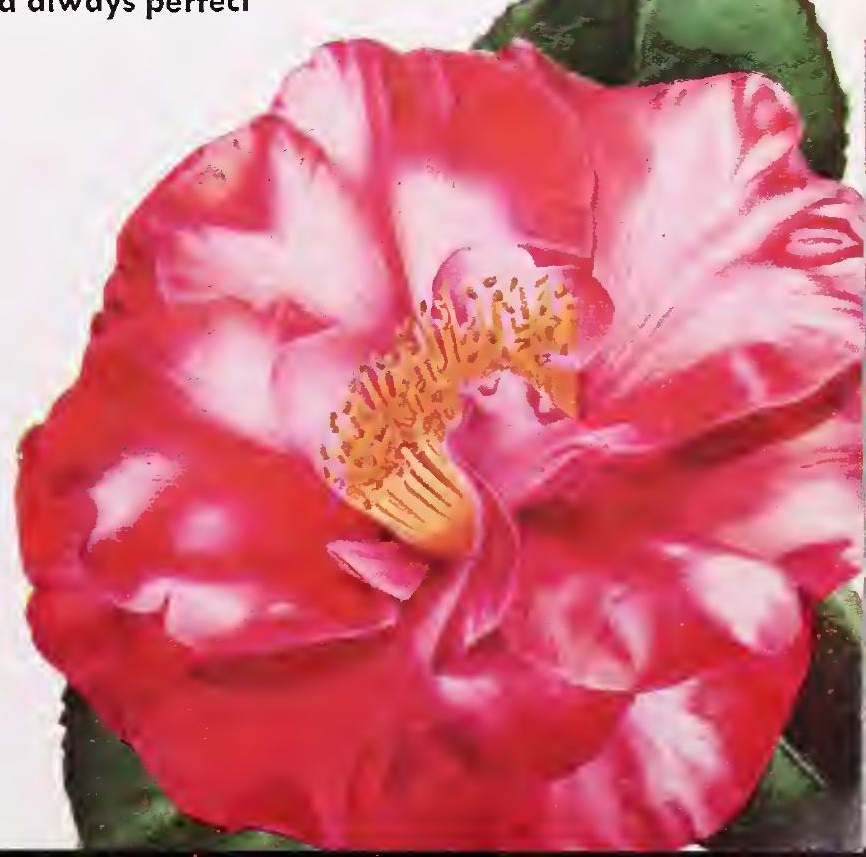




\section{Armstrong Camellias}

\section{Fimbriata The Frilled Camellia}

A large, snow-white, formal double, with never one of the many petals out of place and each one fringed or fimbriated at the edges (see photo at left). A beautiful camellia, resembling the famous Alba Plena except for the uniquely edged petals. The plant is low-growing and spreading. It blooms early.

4170-Gal, tins, $\$ 3.50$. 4171-5-gal. tins, $\$ 12.00$.

\section{Emperor of Russia}

The large $31 / 2$ to $41 / 2$-inch flowers have very large petals around the outside with three groups of smaller wavy petals in the center. It makes a highcentered arrangement of great beauty. The color is brilliant scarlet. Plant semi-dwarf with beautiful shiny foliage. Blooms early to midseason.

$$
4110-\text { Gal. tins, } \$ 3.00 \text {. } \quad 4111-5 \text {-gal. tins, } \$ 9.50 \text {. }
$$

Camellia Fimbriata.

\section{Firebrand}

The large, semi-double flowers are a brilliant, dazzling orange-red with 4 rows of large petals and sometimes with additional petaloids. Nearly always they show a lovely contrasting cluster of bright buttercup-yellow stamens. A strong, bushy free-blooming plant with shiny dark green foliage. Midseason.

$$
\text { 4190-Gal. tins, } \$ 2.25 \text {. 4191-5-gal. tins, } \$ 7.50 \text {. }
$$

\section{Francine Giant Flowers on Dwarf Plant}

A solid pink form of the marvelous Elegans (Chandler) illustrated on page 34. The exceedingly large flowers, 5 to 6 inches across, have very large petals surrounding a thick tuft of petaloids in the center. The color is a bright shade of rose-pink. The plant is dwarf and slow growing, but often even very small plants, 12 to 18 inches high, will produce a half dozen enormous flowers. Early to midseason. $\quad 4220-G$ al. tins, $\$ 3.50$. 4221-5-gal. tins, $\$ 12.00$.

\section{Fred Sander (Fimbriata Superba)}

Of all the new camellias, this is one of the most novel, yet it is just as lovely as it is unique. The flower is large, 4 inches or more across, and the color delightful-a very rich currant-red. About three rows of huge crinkly, wavy petals, loosely arranged, surround a small tuft of golden stamens. But the first thing you see is the unusual and deepcut fimbriation along each petal's edge. This effect is even more spectacular than in the variety Fimbriata shown above. The plant is a vigorous one, fairly erect in habit, yet compact and beautifully foliaged. Blooms midseason to late.

$4180-$ Gal. tins, $\$ 4.50$.

\section{General Douglas MacArthur}

One of the darkest red camellias which we have. The flowers are very double, of medium size, $31 / 2$ to 4 inches in diameter, and are variable in form. At times the center petals vary in size and are mixed, giving a peony form effect. The strong growing plant is one of the best foliaged of all camellias. Blooms early midseason.

$$
\text { 4230-Gal. tins, \$3.00. } 4231-5 \text {-gal. tins, } \$ 9.50 \text {. }
$$

Mathotiana (Julia Drayton)-the largest of all red camellias
Mathotiana Rosea

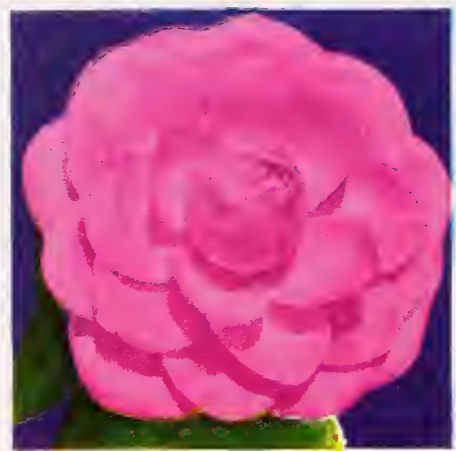

\section{General George Patton}

This new pink camellia is one of the finest of all camellias for cutting. The lovely bloom is larger than average, $31 / 2$ to 4 inches across, sometimes fully double to the center with petals more or less uniform in size, and sometimes with a small tuft of petaloids at the center. Either way they are exceedingly beautiful. The plant is tall and upright, vigorous and blooms with the greatest profusion even while very young. Every bud opens to a perfect flower. Early to midseason. $\quad 4240-$ Gal. tins, $\$ 3.50$. $4241-5$-gal. tins, $\$ 12.00$.

\section{Gigantea Tremendous in Every $W$ ay}

This spectacular variety is fittingly named, and if you want your camellia flowers huge, and your plants covered with extremely large foliage and showing tremendous vigor and growth, then this is the one for you. Flowers are truly gigantic, semi-double, with extremely large petals of bright deep red, marbled and blotched with white, with a tuft of petaloids in the center. The contrast between the deep red and the snowy white is startling in effect. Almost everything about the variety is startling. Blooms in midseason.

$$
\text { 4250-Gal. tins, } \$ 3.50 \text {. } 4251-5 \text {-gal. tins, } \$ 12.00 \text {. }
$$

\section{Glen 40 The Red Everyone W ants}

Everyone who sees a perfect bloom of this new red camellia wants a plant right away. When you see the bloom you will understand why. The very large flower, 3 to 5 inches across, is quite double, with many broad, beautifully imbricated petals of deep red. The color plate on the next page fails to capture the orange-scarlet undertone which gives the flower such a brilliant effect. The plant is semi-dwarf beautifully foliaged with lustrous dark green leaves, and we have seen blooms on young plants before they were even 6 inches high. This variety has been scarce and high priced, but we have a good supply for the coming season and have them priced very reasonably. Glen 40 is one of the special All-Star Trio described on page 39. Midseason to late. $4260-$ Gal. tins, $\$ 4.25$. 4261-5-gal. tins, $\$ 15.00$.

\section{Gypsy The Darkest Red}

The medium size, formal double, $31 / 2$-inch flowers are the darkest to be found among red camellias in this class. They are a deep glowing cherry-red. The plant is a strong grower with abundant broad dark green foliage and you can cut the ruby-hued, long-lasting flowers with long stems. Blooms late.

4270-Gal. tins, \$3.50. 4271-5-gal. tins, $\$ 12.00$.

\section{Herme The Fragrant Camellia}

The large, 4-inch, semi-double flowers of bright rose-pink have a broad, irregular border of white around each big petal, and occasionally stripes of bright red running the length of the petal. This is one of the few fragrant camellias, possessing a delicate sweet perfume. See illustration above. The tall, slender plant is a splendid vigorous grower, with fine-looking foliage. Sometimes sold as "Jordan's Pride." $4280-$ Gal. tins, $\$ 2.25$. $4281-5$-gal. tins, $\$ 7.50$ 
High Hat One of the Earliest to Bloom

Here is a new variety which has aroused a lot of enthusiasm among the camellia experts because it combines so many desirable features. Like Daikagura, of which it is a sport, it starts to bloom extremely early and you can start cutting flowers for corsages or arrangements as early as October. The peony-like flower, $31 / 2$ to 4 inches across, is delicate shell-pink in color, with lovely irregular veinings of deep rose-pink radiating from the base of each petal and fading at the outer edge. The plant is slow-growing and rather upright, but with plenty of large, deeply serrated foliage. $\quad 4285-$ Gal. tins, $\$ 4.50$. 4286-5-gal. tins, $\$ 15.00$

\section{J. C. Williams A New English Hybrid}

The first question everyone seeing this new and rare English hybrid asks is, "When can we get plants?" Now, it is offered here for the first time. All the charm of a perfect single camellia is captured in its perfect flower, washed with delightful tones of soft delicate pink. Unlike the flowers of most single camellias these are absolutely perfect in every detail, with each heavy textured petal semi-erect but flaring to a graceful 3 to $31 / 2$-inch bloom. You'll seldom find a camellia which flowers more freely, and the fast-growing plant is extremely attractive, with a gracefully arching habit and rather small long narrow leaves. For a colorful winter-blooming shrub, this is hard to beat.

$4290-$ Gal. tins, $\$ 5.00$

\section{Lady Clare}

"Spectacular" best describes this giant, semi-double, pink camellia. With its 15 to 20 large satiny pink petals surrounding a tuft of bright golden stamens. The big 4 to 5 inch bloom is a marvelous sight. Too big for a corsage flower, but a beauty in the garden or for bowl display. Midseason to late.

$4330-$ Gal. tins, $\$ 3.00$. $4331-5-\mathrm{gal}$. tins, $\$ 9.50$.

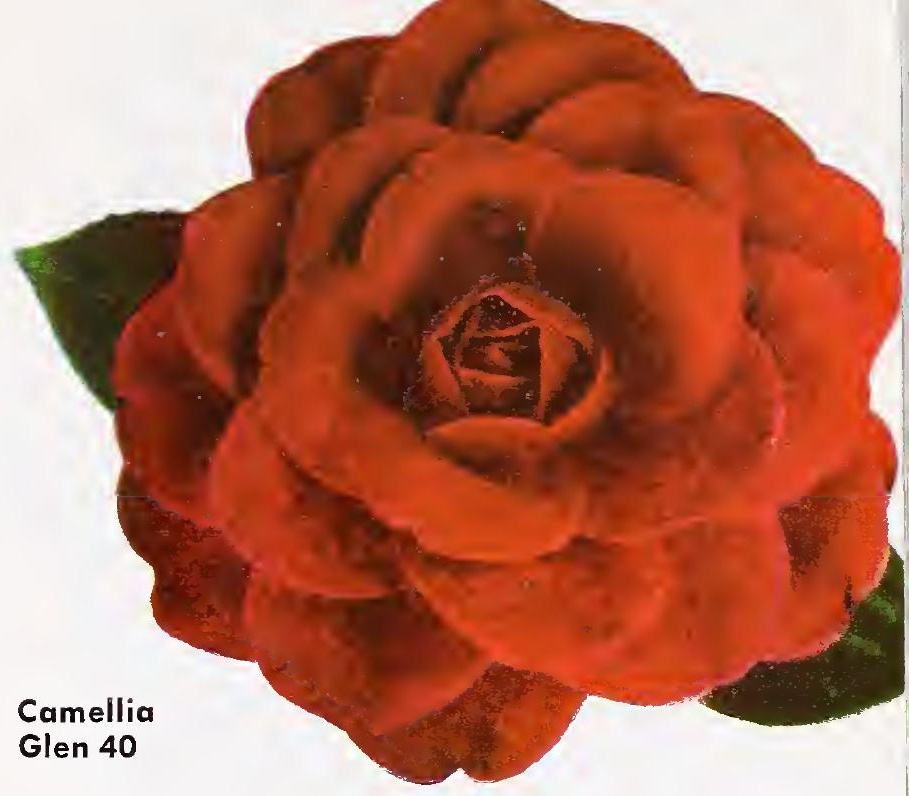

\section{Lady Vansittart}

The large, semi-double, vivid deep pink blooms have 3 rows of broad, wavy-edged petals, symmetrically arranged. The glossy wavy foliage is among the most beautiful in camellias, and the plant sets buds by the dozens. Midseason to late. 4341-5-gal. tins, $\$ 7.50$.

Lalla Rookh (Laurel Leaf)

A perfect formal double, $31 / 2$ to 4 inches across, of delightful rosepink sometimes marbled white. The flower opens rather flat but retains a bud-like center and is very graceful, with the many narrow petals having recurved edges-marvelous for corsages or arranging. Tall-growing, the plant is rather open and has long, slender leaves. Blooms early to midseason. $4350-$ Gal, tins, $\$ 3.50$

\section{Leona Bolen}

The blooms are 3 to 4 inches across, with 3 or 4 rows of enormous rich velvety red petals which fairly radiate warm color. The cluster of yellow stamens in the center accentuates the brilliant red shade. Fine long-keeping flower for cutting purposes. The plant is fairly slow in growth but bushy and luxuriantly foliaged, blooming well. Midseason. $\quad 4360-$ Gal. tins, $\$ 3.00$. 4361-5-gal. tins, $\$ 9.50$

\section{Lila Lee The Beautiful New White}

A new snowy white camellia, produced by J. S. Armstrong, Presiden of the Armstrong Nurseries. It is a peony form flower, 3 to $31 / 2$ inches across. We believe it to be one of the finest white camellias for corsage use because the flower has good substance and will last a long time. The lovely texture and delightful form give the bloom more daintiness and charm than can be found in any other camellia. The plant is very vigorous, with glossy medium sized foliage, and it has a habit of setting so many flower buds that it may be necessary to remove part of them to get size of bloom. Blooms early midseason. Plant Pat. No. 891. 4370-Gal. tins, $\$ 4.25$. 4371-5-gal. tins, $\$ 15.00$

Gigantea will sometimes be 5 or 6 inches across

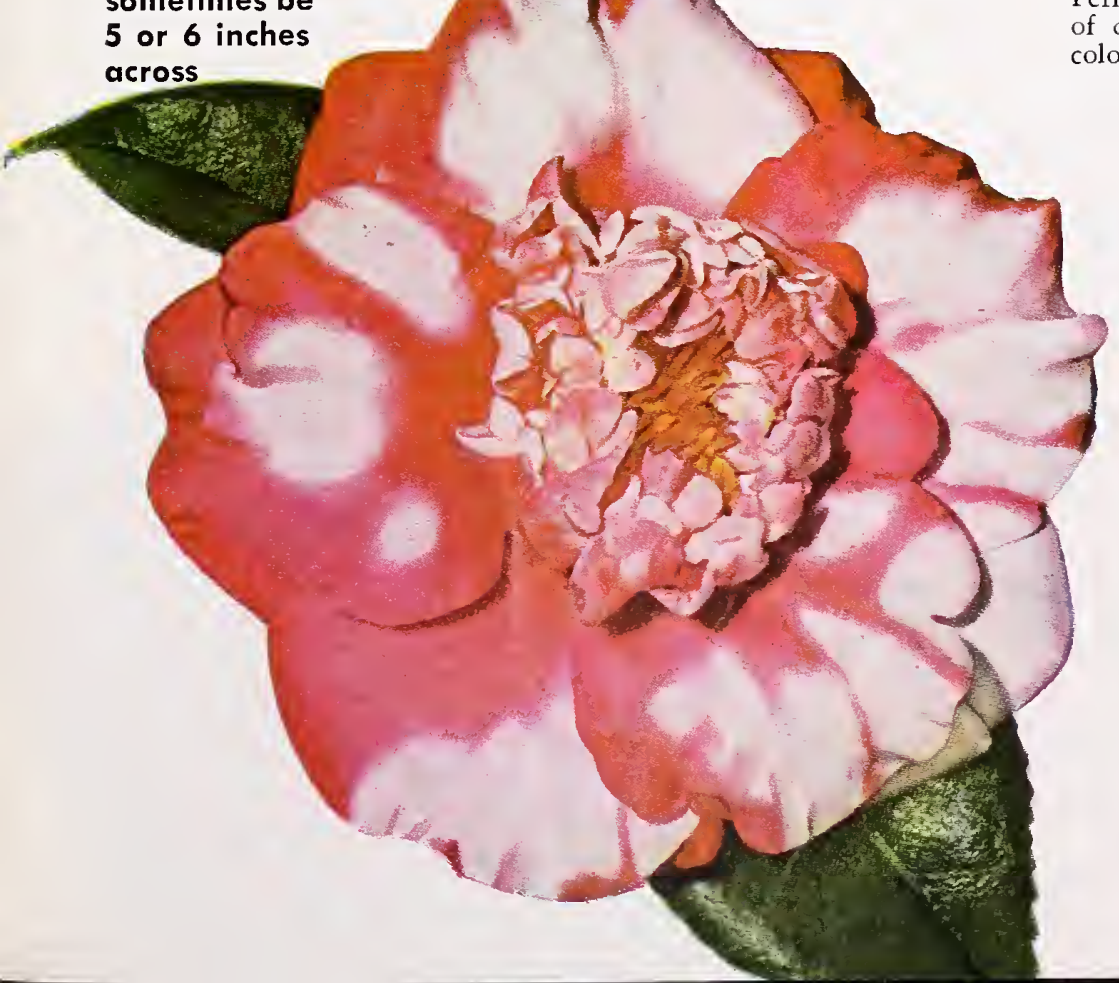

\section{Lorelei}

This seedling developed in the Armstrong Research Department features flowers which are distinctive in form and have no comparison. Four to five inches in diameter, they are a lovely deep rose-pink in color, with the outer petals broad, fully imbricated, and pleasingly crimped at the edges. When fully open they display a tuft of petaloids with stamens intermingled at the center. The fine plant is vigorous, very compact, and heavily foliaged. It flowers almost immediately. Late midseason. 4375-Gal. tins, $\$ 3.50$.

4376-5-gal. tins, $\$ 12.00$.

\section{Lotus The $W$ ater Lily Camellia}

The huge cup-shaped flower of this unusual camellia resembles a gigantic water lily, with 3 rows of snow-white petals. The best flowers are produced on plants in full shade, but all of the flowers are lovely. Compact, handsomely foliaged plant which blooms while very young. Blooms midseason. $4380-$ Gal. tins, $\$ 4.25$. 4381-5-gal. tins, $\$ 15.00$.

\section{Mathotiana (Julia Drayton)}

The largest and showiest red camellia that we grow. Always beautifully veined and textured, the huge flowers, often 6 inches across, are a uniform shade of brilliant scarlet. Very double, they usually have a high pointed bud-like center, as shown in the illustration on page 36. In the aging flower, or in some weathers even the newly opened blooms will show an attractive tuft of golden stamens instead. The clear bright color and enormous size make this one of the most spectacular and magnificent of all camellias. The plant is very strong and fast-growing, with large luxuriant foliage. 'This is a featured variety in ou.r Cornerstone Collection offered on page 39. Blooms midseason to late. $4410-$ Gal. tins, $\$ 3.50$. $4411-5-$ gal. tins, $\$ 12.00$.

\section{Mathotiana Rosea}

Perfectly formed 3 to $31 / 2$-inch flowers, large petaled-formal double of dainty clear pink. Delightful in form with marvelous clarity of color. Blooms late. 


\section{Armstrong Camellias}

\section{Marchioness of Exeter}

In size, brilliancy of coloring, and perfection of form, this beautiful pink camelliapale salmon-pink with occasional white markings-is possibly the loveliest of its type. The gigantic, 4- to 5 -inch, peony form flowers are crowded with petals, gracefully arranged. A spreading willowy plant. Blooms early. 4390-Gal. tins, $\$ 3.00$.

4391-5-gal. tins, \$9.50.

\section{Margarete Hertrich New Formal W bite}

After having grown this splendid variety for several seasons, we still hold our original opinion that it is the most perfect and beautiful of the fully double, formal type, white camellias. The flowers are medium size, with row after row of petals arranged in perfect symmetry. There is never one out of place from the outermost to the center of the flower. In contrast to the delicate beauty of the flower, the plant is a big vigorous one, setting plenty of flower buds. Blooms midseason.

$4400-$ Gal. tins, $\$ 4.25$. $\quad 4401-5$-gal. tins, $\$ 15.00$.

\section{Meredith Lake}

Semi-double, 3 to $31 / 2$ inches across. The big petals are a pale delicate pastel pink. They make lovely cut flowers for dish or corsage and the bushy, medium size plant blooms freely. Late.

$4450-$ Gal. tins, $\$ 3.50$.

\section{Monjisu}

If we were asked to select the camellia producing the most blooms per plant, this would be our choice. The semi-dwarf plant is especially useful for growing in tubs or in places where you want a lot of bloom in a small space. The medium size flower is rosy cherry-red with white spots. An open high-centered flower, the velvety textured petals contrast delightfully with the golden yellow stamens. You'll have flowers on this the very first blooming season after you plant. Midseason to late. 4460-Gal. tins, $\$ 3.00$. 4461-5-gal. tins, $\$ 9.50$.

\section{Mrs. Charles Cobb}

This is one of the very few good red camellias with large perfect blooms. Peony type, but all of the petals, even those in the tufted center, are large. The deep rich glowing red never shows any blue tones even as it ages. The plant is bushy and upright. Midseason to late. $4470-$ Gal. tins, $\$ 3.50$. 4471-5-gal. tins, $\$ 12.00$.

\section{Mrs. Tingley}

This beautifully imbricated formal double is a delightful soft shade of pink, 3 to $31 / 2$ inches across. New and still rather scarce, you will not yet find it in many camellia gardens. The plant is vigorous, rather tall and open. It blooms early and you can enjoy cutting some of your first camellias from it.

4485-Gal. tins, \$3.50. 4486-5-gal. tins, \$12.00.

\section{Pax}

If you want a long lasting exquisite white camellia, this is one of the best. The heavy wax-like petals unfold into a perfect formal double arrangement, rather flat, but still graceful because the high bud-like center remains until the last. With this kind and Alba Plena in your garden, you can cut perfect white blooms over a long season. Pax begins where Alba Plena leaves off and both are exceptionally fine for corsage or bowl arrangements. The plant is rather slender and upright with long narrow leaves. It blooms freely from January to April.

4510-G al. tins, $\$ 3.50$.

4511-5-gal. tins, $\$ 12.00$.

\section{Pink Perfection (Frau Minna Seidel)}

The most popular camellia ever grown. Its formal double, mediumsized blooms of delicate light pink are always charming and it blooms from Thanksgiving right through to late spring. An extremely vigorous plant. No camellia planting is complete without this fine variety. Incidentally, it is included in our Cornerstone Collection described on the opposite page.

4520-Gal. tins, \$2.25. 4521-5-gal. tins, \$7.50.

\section{Prince Charming}

For beauty of form and clarity of color, we think this brand new Armstrong seedling is one of the finest camellias we have seen in a long while. The flower measures $31 / 2$ inches across and is of clear deep rose-pink. Its big waxy petals form a high-centered semi-formal arrangement with the rosebud center unfolding into a tuft of tiny petaloids. The plant of medium height is extremely vigorous and handsome. Mid to late season. Plant Pat. No. 907.

$$
\text { 4540-Gal. tins, \$3.50. 4541-5-gal. tins, \$12.00. }
$$

\section{Prince Eugene Napoleon (Pope Pius IX)}

Huge rosy red flowers up to 4 inches across, in a beautifully imbricated double flower. It opens out into a broad flat bloom, perfectly symmetrical, and it never shows an open center. The color is much softer and more pleasing than the color plate on the opposite page would indicate. It is a big strong plant-one of the easiest of all to grow. Early to midseason.

$$
4550-\text { Gal. tins, } \$ 3.50 \text {. } \quad 4551-5-\mathrm{gal} \text {. tins, } \$ 12.00 \text {. }
$$

\section{Princess Bacciochi}

Among the very double peony form camellias, this is one of the best The color is a rich velvety carmine-red and you seldom find a flower that is not perfect. It is one of those kinds which is a pleasure to grow because of its splendid and consistent performance. Blooms midseason. $\quad 4560-$ Gal. tins, $\$ 2.25$. $4561-5$-gal. tins, $\$ 7.50$
Pink Perfection is everyone's favorite

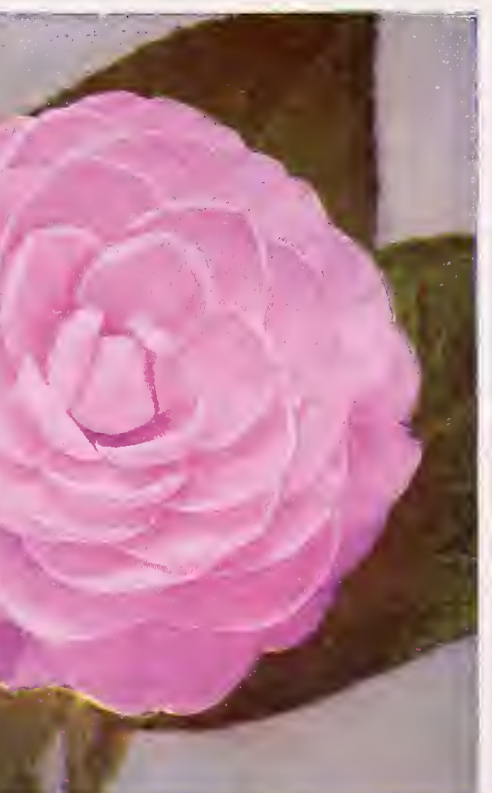

\section{Prof. C. S. Sargent}

This will be one of the most satisfactory red camellias in any garden. The deep scarlet flower, 2 inches across, is crowded with many small petals and is full and round almost like a pompon chrysanthemum. The flower often carries more than 200 petals and the color is extremely deep and rich. The small-growing plant blooms very freely and is one of the hardiest of all camellias. Midseason to late.

$4570-$ Gal tins, $\$ 3.00$ 4571-5-gal. tins, $\$ 9.50$.

\section{See Them in Bloom}

Through the late winter and early spring months each of our five salesyards is a colorful sight, with thousands of camellia blooms covering the plants. We cordially invite you to stop in whenever it is convenient. Be sure to see and enjoy this lovely display.
Professor C. S. Sargent

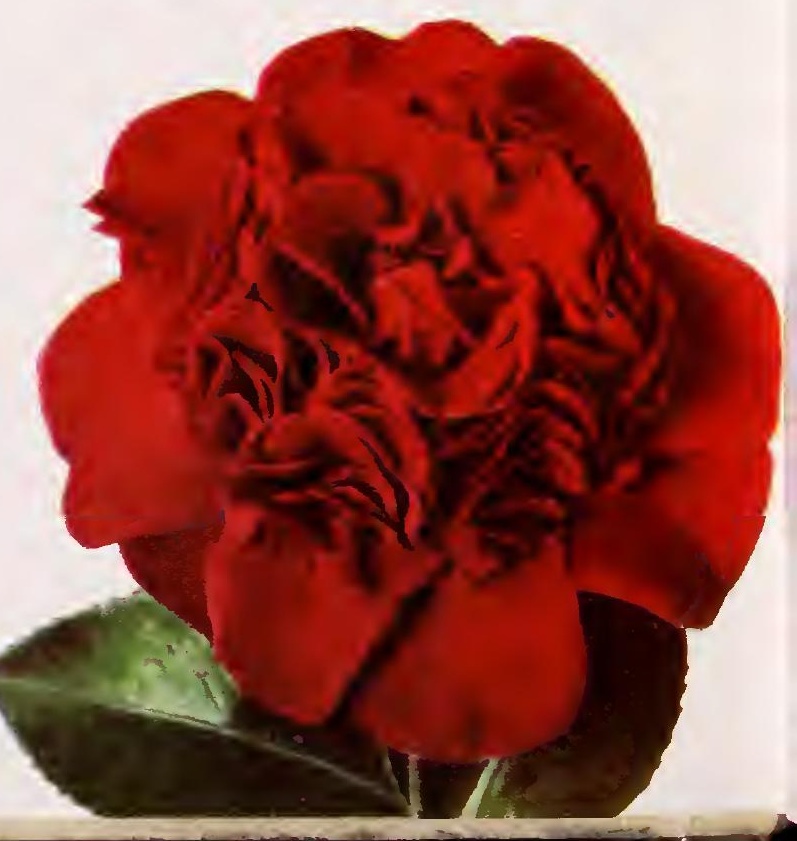




\section{Purity Most Popular Wbite}

Its name describes it. Symmetrical, exquisitely formed, double, snowy white blooms of large size, $31 \frac{1}{2}$ inches across, every one perfect, just right for cut flowers. Since it blooms late in the season, the flowers of this variety are nearly always available at Easter-time. Included in our popular Cornerstone Collection below. 4580-Gal. tins, \$2.25. $\quad 4581-5$-gal. tins, \$7.50.

Princess Bacciochi

\section{Regina dei Giganti}

A lovely salmon-pink color distinguishes this beautiful camellia. The large flower is $41 / 2$ inches across with two rows of large outer petals and the center of the bloom is filled with long petaloids. It blooms with great abandon, even young plants producing many fine flowers. The plant is compact, well branched, and upright in habit with large glossy leaves. Midseason. $\quad 4600-$ Gal. tins, $\$ 3.00$. 4601-5-gal. tins, $\$ 9.50$

\section{Rose Dawn}

The very lovely flowers of this variety are perfectly formed completely double, about $31 / 2$ inches in diameter. Warm deep pink in color. The foliage is possibly the hand somest of any camellia variety, large and hollylike in appearance. Blooms midseason. $4640-$ Gal. tins, $\$ 3.50$. $4641-5$-gal. tins, $\$ 12.00$

\section{Camellia reticulata Captain Rawes}

Most of our camellias are varieties of Camellia japonica, but this is an entirely different species. The flowers are very large, 3 to 5 inches across, sparkling bright pink in color. They are semi-double, with broad, wavy, fluted petals and have a rich iridescence to the color which is found in no other camellia. It is a captivating color, and once you have seen it, you can understand why there has been so much excitement about it. The plant is vigorous, with light green foliage; more open in habit than Camellia japonica. Blooms late.

$$
4610-\text { Gal. tins, } \$ 5.00 \text {. } 4611-5 \text {-gal. tins, } \$ 15.00 \text {. }
$$

\section{Rosea Superba}

Enormous in size, $4 \frac{1}{2}$ to $51 / 2$ inches, with big, broad, flaring petals. This big, rich rose-pink camellia is majestic and stately in appearance. The form is perfect with never a petal out of place. The big, bushy, broad-foliaged plant blooms midseason to late.

$$
4630-\text { Gal. tins, } \$ 3.50 \text {. } 4631-5 \text {-gal. tins, } \$ 12.00 \text {. }
$$

\section{Shangri-La}

A peony type flower, $31 / 2$ to 4 inches across, full and high-centered. It is a variation of the delightful Daikagura which blooms so early in the season and keeps coming throughout the winter only the color here is a rich striking crimson. Delightfully fragrant.

$$
4700-\text { Gal. tins, } \$ 3.50 \text {. } 4701-5 \text {-gal. tins, } \$ 12.00 \text {. }
$$

\section{Te Deum}

The most brilliant color imaginable, a vivid blood-red, with a strikingly beautiful flower form. The large outer petals are beautifully imbricated framing a cluster of many small petaloids in the center A strong vigorous grower, the plant has big shiny leaves. Its glistening brilliant red color and long-lasting cut flower qualities are increasing its popularity each year. Midseason.

$4720-$ Gal. tins, $\$ 3.50 . \quad 4721-5$-gal. tins, $\$ 12.00$.

\section{Vanity Fair}

Exactly like Lady Vansittart, but the broad velvety-textured petals are a brilliant cardinal-red. Has the same attractive glossy foliage. Midseason to late. $4730-$ Gal. tins, $\$ 2.25$. $4731-5$-gal. tins, $\$ 7.50$.

\section{Victor Emanuel (Blood of Cbina)}

An informally arranged flower, breath-taking in its brilliant scarletorange color, full and high centered. The bloom consists of a large loosely packed cluster of folded wavy petaloids with an occasional brilliant yellow stamen peeping out. The plant is vigorous, spreading, with particularly fine foliage. Blooms midseason to late.

4740-Gal. tins, $\$ 3.00$. $\quad 4741-5$-gal. tins, $\$ 9.50$.

\section{Ville de Nantes}

Here is something unique in camellias. A big bright red flower with each petal fimbriated or sharply frilled as shown in the white Fimbriata illustrated on page 36 . The flowers are large, $41 / 2$ to $43 / 4$ inches across, sometimes flat with wavy undulating margins and sometimes high-centered, but always striking. The plant is moderately vigorous. Blooms midseason. Put a flower of this in a camellia bowl in your living room and it is sure to attract attention.

$$
\text { 4750-Gal. tins, } \$ 4.25 \text {. } \quad 4751-5 \text {-gal. tins, } \$ 15.00 \text {. }
$$

\section{A Lovely Single}

\section{Camellia saluenensis}

Day after day for many weeks in the late winter and early spring, the graceful arching plant, with its small narrow leaves, is literally loaded with bloom. The charming single flowers are 2 to $21 / 2$ inches across and are dainty apple blossom pink in color. Makes an exceedingly attractive ornamental shrub.

4660-Gal. tins, $\$ 5.00$.

\section{Save on These}

\section{Armstrong Camellia Collections}

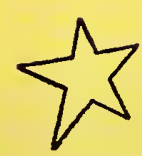

\section{All-Star Trio}

The three camellias offered in this collection are the finest in their class. For those of you who want somerhin special and out-of-the-ordinary, something of which you can be exceedingly proud, these are the best the camellia world affords.

Alba Plena. White. See page 34.

Glen 40. Red. See page 36.

Eleanor Hagaod. Pink. See page 35.

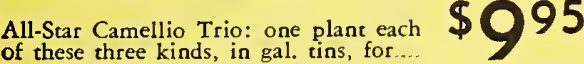

Alsa available in 5-gal. tins af $\$ 37.50$.

\section{Cornerstone Collection}

Here is a group of the most dependable camellias at a reasonable price. Four lovely and easy-to-grow kinds which you will be proud to have in your garden.

Mathatiana. Red. See page 37.

Purity. White. See above.

Pink Perfectian. Pink. See page 38.

Elegans. Marbled. See page 35.

Cornerstone Collection: One each of the above in gal. tins, for. 


\section{Evergreen Shrubs}

Where to Plant: Each description includes the approximate average height to which the plants will grow, whether the plant prefers sun or shade, and the approximate minimum temperature at which the plants will be damaged by frost. These temperatures are approximate only, since the age and condition of plants during cold weather have much to do with their resistance to frost. In California the plant would probably be injured if the temperature reached the figures mentioned for several hours, but often the plant would recover. In other states, where the temperatures may reach these figures many times in a season such plants should not be used. See planting guide on page 30.

Shipping Weights: Packed for shipment by express or freight, plants in gallon tins weigh approximately $10 \mathrm{lbs}$. each; 5 -gal. tins, approximately $50 \mathrm{lbs}$. each. Balled plants will average 70 lbs. each. See page 3 for information covering the shipment of ornamentals in containers.

Plant Shrubs Any Time: The black squares under every month indicate that you can plant evergreen shrubs every month in the year.

\begin{tabular}{|c|c|c|c|c|c|c|c|}
\hline Month & J F & M & A $\mathbf{M}$ & $\mathbf{J} \mathbf{J}$ & A $\mathbf{S}$ & $\mathrm{O} N$ & D \\
\hline is or Balled & & & & 1 & & & \\
\hline
\end{tabular}

Quantity Discounts:

Flowers of the glossy leaved Abelia grandiflora

See the table on page 31 for the discounts which apply on purchases of ornamental plants.

\section{Abelia grandiflora Glossy Abelia}

The small, shiny, bronze-green foliage, and arching stems continually clothed with clusters of little fragrant rosy white flowers make this plant exceedingly valuable for mass or foundation planting. It will grow to over 6 feet in height, but can be kept low by pruning. Since flowers are produced on new wood, it can be pruned severely without harming the plant. It is perfectly hardy anywhere. Evergreen in warmer sections, it may go partly deciduous in colder areas. Plant in full sun or partial shade. $6 \mathrm{ft}$. $0^{\circ}$.

$4800-$ Gal. tins, $\$ 1.25$. $4801-5$-gal. tins, $\$ 4.25$.

\section{Abelia Goucher}

This is a hybrid of Abelia grandifiora, and it greatly resembles that variety in size and habit. There the similarity ends, because this one has much larger flowers, lavender-pink in color, with orange markings at the throat and a delicate lilac scent. The foliage, too, is slightly larger, and the bronzy tones are usually more pronounced. If you want an Abelia especially bright and very showy, this is the one you should plant. $6 \mathrm{ft}$. $0^{\circ}$. $\quad 4795-$ Gal. tins, $\$ 1.25$. 4796-5-gal. tins, $\$ 4.25$.

\section{Abutilon vitifolium Vesuvius Red Flowering Maple}

This is the showiest of all the Flowering Maples. Its outstanding characteristic is the large 2-inch, bell-shaped flowers of brilliant orange-scarlet. Almost always in bloom, the bright colored flowers are spectacular against the light green maple-like foliage. A fast-growing plant which should be in sun or part shade. $5 \mathrm{ft} .24^{\circ}$

\section{Acanthus mollis}

The huge notched leaves of polished green, sometimes 2 feet long, supposedly inspired the floral motif seen on Corinthian pillars. In the ground, in a planter or tub, a graceful clump of the big tropical-looking foliage fits perfectly into the modern planting. Sun or part shade. $4 \mathrm{ft} .20^{\circ}$. 4823-Gal. tins, $\$ 1.25$

\section{Adenocarpus foliolosus Canary Island Lupine}

The feathery bright green foliage is attractive throughout the entire year, but the plant fairly sparkles during April, May and June, when the tip of every bright green branch is a glowing mass of brilliant yellow flower spikes--each one resembles a giant yellow lupine. Can be used as a specimen plant, as a large background shrub, or can be used as a large hedge. Especially valuable in dry desert areas. Plant in full sun, fairly dry soil. 8 to $10 \mathrm{ft}$. $15^{\circ}$. 4825-Gal. tins, $\$ 1.25$. $4826-5$-gal. tins, $\$ 4.25$.

\section{Agapanthus africanus Blue Lily-of-the-Nile}

Along the Pacific Coast, the handsome, deep green straplike leaves remain perfect the year around. In early summer, long 2 -foot stems are crowned with huge 8 -inch heads of sparkling blue flowers. Excellent for foreground planting because the foliage stays low and the long-stemmed flower heads show to perfection against the background shrubs. $15^{\circ}$.

4830-Gal. tins, $\$ 1.25$

\section{Arbutus unedo Strawberry Madrone}

A bushy, spreading, medium sized shrub with green foliage very similar to the native Madrone. Has many delightful little, pearly white, bell-shaped flowers in summer, followed by clusters of brilliant red fruits, resembling strawberries which ripen about Christmas time. Stands heat, cold, and drought. Sun or part shade. 6 to $10 \mathrm{ft}$. or larger. $15^{\circ}$. $4850-$ Gal. tins, $\$ 1.50$. $4851-5$-gal. tins, $\$ 4.75$. $6885-$ Balled, 2 to $3 \mathrm{ft}$., $\$ 7.50$. 6886 -Balled, 3 to $4 \mathrm{ft}$., $\$ 9.00$ 6887 -Balled, 4 to $5 \mathrm{ft}$., $\$ 12.50$.

\section{Arbutus unedo compacta Compact Strawberry Madrone}

Very similar to the above but has a more upright, compact, rounded form. A little slower growing, it has the same holly-like leaves, dainty flowers, and red fruits. Flowers and fruits heavily while quite young. Grows anywhere. Sun or part shade. 6 to $8 \mathrm{ft} .15^{\circ}$. 4856-5-gal. tins, $\$ 5.25$.

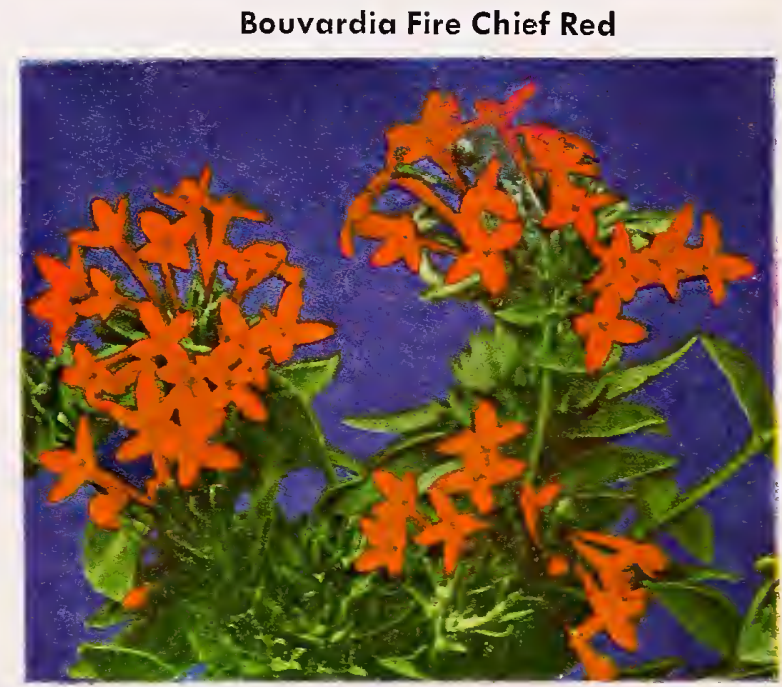

Flowers of Berberis darwini

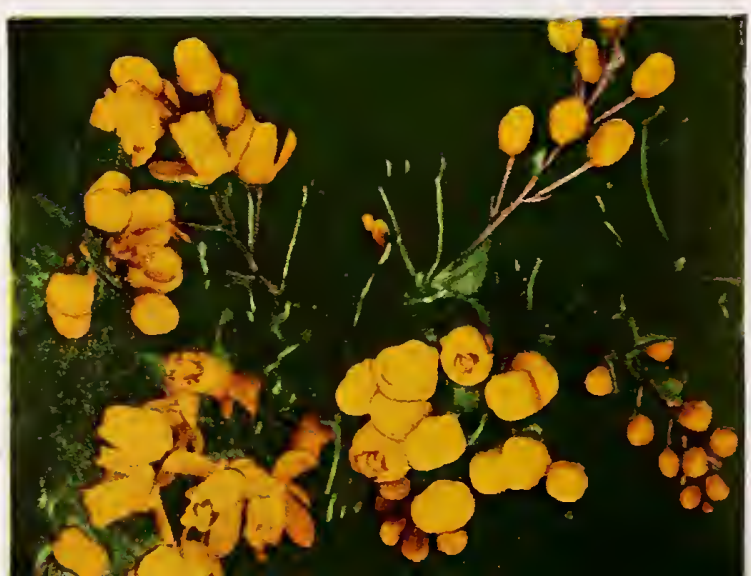




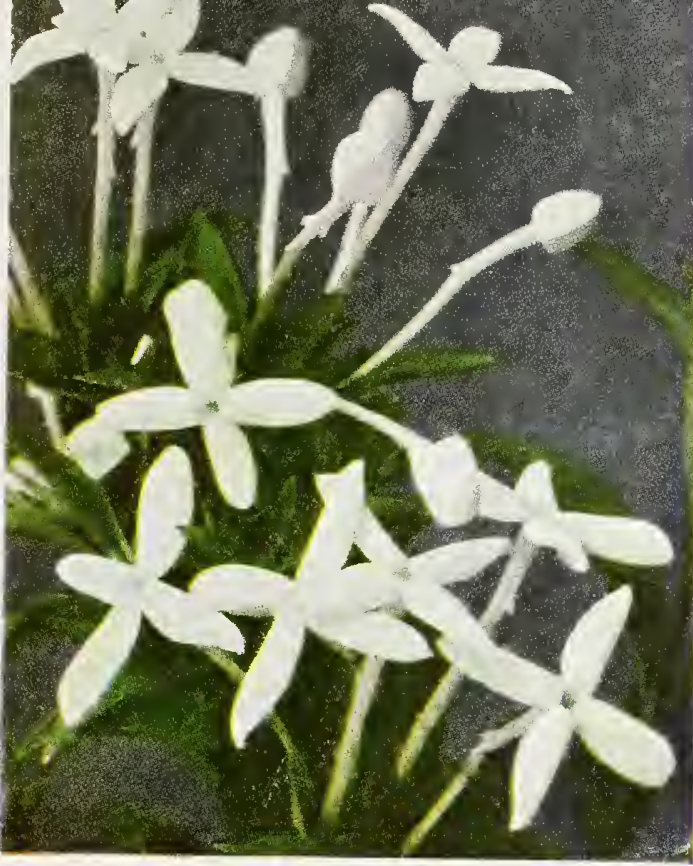

Intensely fragrant Bouvardia Albatross
Aster fruticosus Shrub Aster

A permanent evergreen shrub, unlike perennial Asters. The dark evergreen foliage is completely covered from April to June with masses of deep lavender or rosy mauve flowers, each 1 to $11 / 2$ inches across. A magnificent garden display with lots of flowers for cutting. Fairly dry soil, full sun. Prune back after flowering season. $3 \mathrm{ft} .20^{\circ}$.

$4870-$ Gal. tins, $\$ 1.25$

\section{Aucuba japonica Golddust Gold Dust Plant}

Big, glossy, 7-inch leaves, lightly dusted with gold. An ideal plant for shady placesperfect against the large expanses of wall in modern homes because of its large tropical-looking foliage. Hardy to about $15^{\circ}$ 4873-Gal. tins, $\$ 1.50$.

\section{Beloperone guttata Shrimp Plant}

The handsome little compact plant bears odd but attractive flower spikes of coppery bronze bracts, enclosing small cream and purple flowers throughout the year. Excellent for cut flowers. Sun or half shade. 2 ft. $24^{\circ}$

$4890-$ Gal, tins, $\$ 1.00$

\section{Bouvardia Albatross White Bouvardia}

A fast-growing informal little plant bearing continuously clusters of intensely fragrant snow-white flowers, each 3 or more inches long and about $11 / 2$ inches across. You'll pay big money for these jasmine-scented flowers at your florist's, so why not grow your own? Simply prune the plants once or twice a year to keep them in bloom. Full sun or semi-shade near the coast; shade inland. 2 to $3 \mathrm{ft.} 27^{\circ}$. $6680-$ Gal. tins, $\$ 1.50$.
Buxus microphylla japonica Japanese Box

For a 2 or 3 - $\mathrm{ft}$. low, evergreen, trimmed hedge, throughout most of California there is nothing better than this variety. Naturally grows low, dense and compact with glossy, bright green, small leaves. An occasional trimming will keep it in any shape you desire. Also useful for trimmed pyramids or globes in the garden or in tubs. 2 to $4 \mathrm{ft.} 10^{\circ}$ $4950-$ Gal. tins, $\$ 1.25$. 4952-Flats of 100 plants, $\$ 8.50$ $6905-B a l l e d$, globes, 1 to $11 \frac{1}{2} \mathrm{ft} ., \$ 7.00$. 6906-Balled, globes, $11 / 2$ to $2 \mathrm{ft}$., $\$ 8.50$. 6912 -Balled, pyramids, 2 to $21 / 2 \mathrm{ft} . \$ 7.00$. 6913 -Balled, pyramids, $21 / 2$ to $3 \mathrm{ft}$., $\$ 8.50$. 6914-Balled, pyramids, 3 to $31 \frac{1}{2}$ ft., $\$ 10.00$

\section{Buxus harlandi Harland's Boxwood}

Lower growing with foliage somewhat smaller and darker green than that of the Japanese Boxwood. It remains shiny and attractive at all times. Grows rapidly anywhere and is very dense and compact. Ideal for hedges from 18 inches to 2 feet. Needs little pruning. $2 \mathrm{ft} .5^{\circ}$ $4947-$ Flats of 100 plants, $\$ 10.00$.

\section{Buddleias Summer Lilacs}

If you want flowers quickly, plant Buddleias and enjoy plenty of deliciously fragrant flower spikes to 16 inches long in the summer and fall. Easily grown and hardy anywhere. $8 \mathrm{ft} .10^{\circ}$

All varieties below: Gal tins, $\$ 1.00$ Buddleia davidi "lle de France" Violent-tinted flowers on spikes 6 to 12 inches long. 4940 .

Buddleia asiatica Fragrant snowy white flowers. 4930.

Buddleia "Charming" Sprays of lavender-pink bloom, often 12 to 16 inches in length. 4935 .

Brassaia actinophylla (Scheffera) A very useful decorative plant having a lush tropical appearance with its great big polished green leaves, 10 inches long. While young it is ideal for indoor planters, or it makes a fine specimen in pot or tub for porch or patio. Grows quite rapidly and eventually it will make a small and very at tractive patio tree. The trend in modern planting is toward large foliaged plants of this type, and this is one of the best. Probably hardy to about $20^{\circ}$. $3065-6$-inch pots, $\$ 3.00$

\section{Brunfelsia calycina floribuncia Yesterday, Today and Tomorrow}

A favorite shrub with us because of its many fine qualities. Throughout the entire year it is densely clothed with broad, glossy, deep green foliage, and it stays compact and good looking always. Every day for over half the year it opens very lovely, waxy textured flowers which change color as they age. Yesterday's flowers were deep violet, today they are lavender, and tomorrow they will be white. In every stage, they fill the garden with an intense sweet fragrance. Few shrubs are better looking, fit so well into every garden, and few flowers have so much fragrance. Plenty of moisture, sun or part shade. $6 \mathrm{ft} .20^{\circ}$

4925-Gal. tins, \$1.75. 4926-5-gal. tins, \$5.25.

\section{Bouvardia ternifolia Fire Chief Fire Chief Red}

The tubular flower clusters on this almost ever-blooming little 3-foot plant have the same glowing brilliant red color that the Fire Chief uses on his car. Color takes the place of fragrance in this showy Bouvardia. Prune severely once or twice a year to keep the flowers coming. Full sun or semi-shade near coast; shade inland. $25^{\circ}$.

$6685-$ Gal. tins, $\$ 1.75$

\section{Bergenia cordifolia}

Big broad thick leaves, making a dense clump about 15 inches high, with quantities of 12-inch spikes of pink flowers all through the winter. The foliage, something like that of Tuberous Begonias, has a bronzy-green tinge. Fine for edging or border plants in full shade. $15^{\circ}$. $4910-$ Gal. tins, $\$ 1.50$

Strawberry-like fruits and lovely flowers of Arbutus unedo

\section{Barberries}

The Barberries are useful ornamentals because of their fine foliage and slow compact habit of growth. They fit well into our California landscape when used as foreground or foundation plants.

\section{Berberis darwini Darwin Barberry}

Small, glossy, dark green, holly-like leaves with brilliant orange-yellow flowers in the spring, followed by plum-colored berries. It has long been and still is one of the most popular medium sized evergreen flowering shrubs for California because of its richly colored, handsome flowers, and showy berries. $\mathrm{Pl}$ ant in sun $\mathrm{Or}$ shade. $6 \mathrm{ft} 0^{\circ}$.

4895-Gal. tins, \$1.50. 4896-5-gal. tins, $\$ 4.75$.

\section{Berberis gracilis}

Similar to Berberis darwini, but much smaller and more compact. Without pruning, it will remain a low, rounded mound of dense attractive foliage. Fine for border or low foreground planting. (Not available until June, 1952.) Sun. 2 ft. $10^{\circ}$ $4900-$ Gal. tins, $\$ 1.75$.

\section{Berberis pruinosa}

Hollygreen Barberry

We think this is one of the most beautiful Barberries because of (1) the beauty and grace of its arching branches. (2) Long 2 -inch, dark green glossy leaves. (3) A few leaves become brillian red in the fall. (4) Bright yellow flowers in late winter. (5) Big, beautiful, blue-black berries. Sun or half-shade. $6 \mathrm{ft} .0^{\circ}$

4905-Gal. tins, $\$ 1.50$.

$4906-5$-gal, tins, $\$ 4.75$

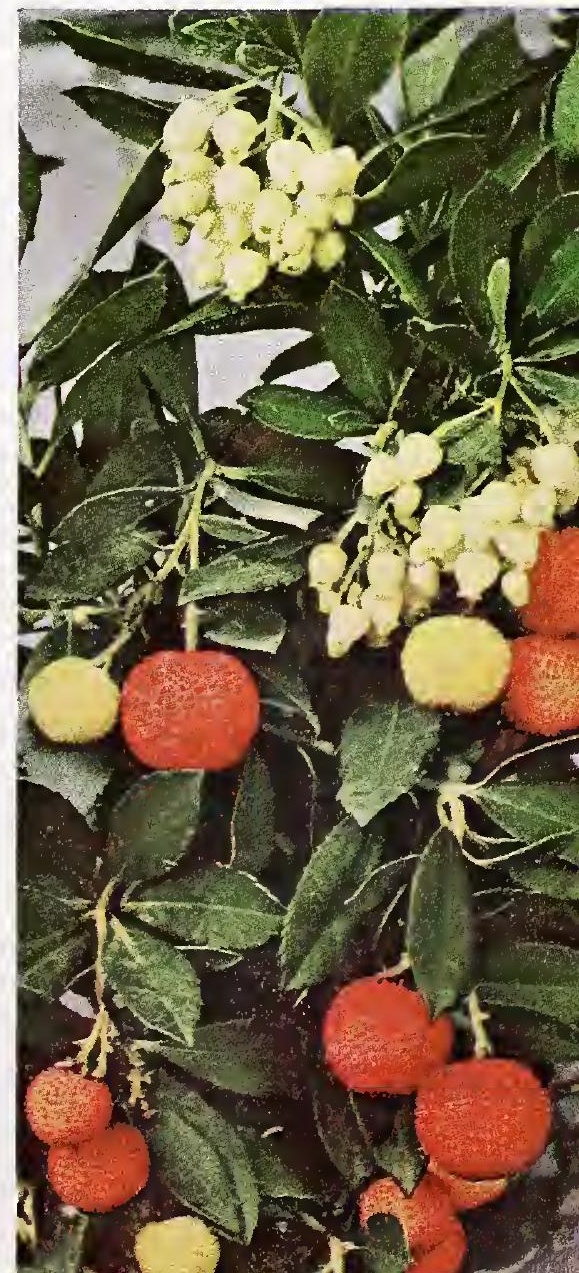




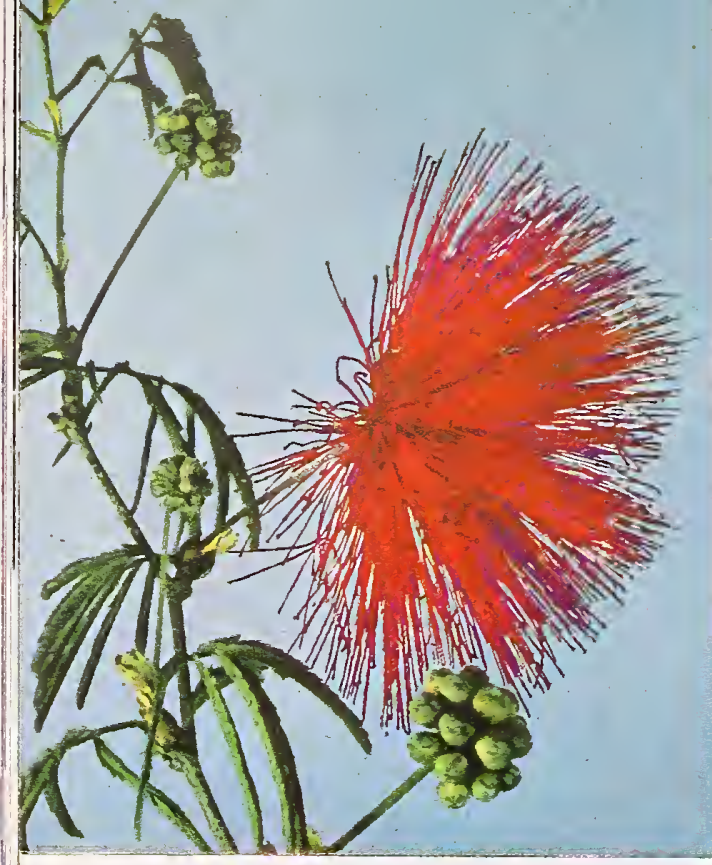

Brilliant flowers of Calliandra guildingi

\section{Calliandra guildingi}

Trinidad Flame Bush

One of the most vivid and spectacular shrubs on our list is this "Flamer" from Trinidad. The large pompon-like heads of vivid scarlet stamens cover the plant like sheets of flame during the spring and summer months. Its open graceful habit and feathery, fernlike evergreen foliage make it a beautiful shrub for planting against a wall or fence. Peeping over lower growing shrubs it creates a very beautiful effect. Full sun. $8 \mathrm{ft}$. $18^{\circ}$. 4955-Gal. tins, $\$ 1.50$. $4956-5-\mathrm{gal}$. tins, $\$ 4.75$.

\section{Carissa grandiflora}

A very handsome shiny-leaved shrub with attractive Howers and fruit. Completely described among the subtropicals on page 97 , it makes a fine ornamental. 5045-Gal. tins, $\$ 1.50$. 5046-5-gal, tins, $\$ 4.75$.

\section{Carissa Alles}

A lower and more spreading plant than Carissa grandiflora but also a handsome ornamental. Fully described on page 97.

$$
\text { 5040-Gal. tins, \$1.50. 5041-5-gal. tins, \$4.75. }
$$

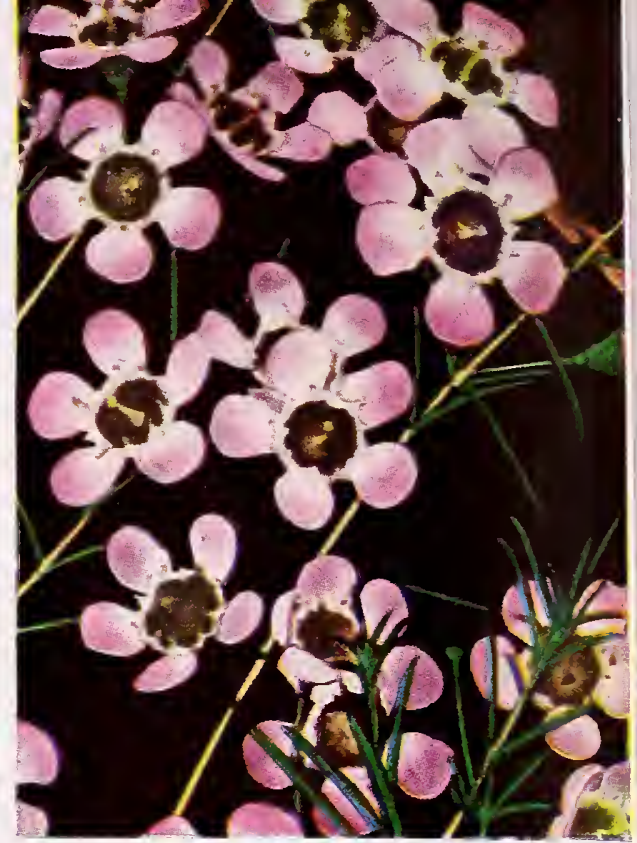

Geraldton Wax Flowers are ideal for arrangements

\section{California Lilacs}

It is easy to have these native California lilacs with their delicate blue flower spikes and their refreshing fragrance in your garden. They thrive most anywhere in well drained soil and full sun.

\section{Ceanothus gloriosus Point Reyes Ceanotbus}

A low, dense mat of glossy evergreen foliage, becoming 6 to 8 feet Across. In late spring it carries masses of bright lavender-blue flowers, very fragrant and lovely. In Southern California it does best in light shade, with plenty of moisture. In the coastal areas north of Santa Barbara it will grow in full sun. $16^{\circ}$. 5065-Gal. tins, $\$ 1.75$.

\section{Ceanothus La Primavera}

A new hybrid wild lilac from Santa Barbara Botanic Gardens. Early in spring the 8 -foot plant carries many large, long spikes of very deep rich blue flowers, exceedingly fragrant. A handsome compact plant which seems long-lived and easy to grow. $12^{\circ}$.

5070-Gal. tins, $\$ 3.00$.

\section{Ceanothus griseus Deep Blue Wild Lilac}

One of the finest of the California Wild Lilacs because of the richness of the deep blue color and the intense fragrance of the flowers. Easyto-grow and long-lived. Dry soil. $6 \mathrm{ft.} 10^{\circ}$ 5075-Gal. tins, $\$ 1.50$.

5076-5-gal. tins, $\$ 4.75$.

\section{Carpenteria californica Fragrant Carpenteria}

One of the most handsome of California native flowering plants, with large good-looking foliage. The single, white, 5-petaled flowers, 2 to $21 / 2$ inches across, look like waxy camellia blooms and they are borne in such profusion as to make the plant look like a mound of snow. They are exceedingly lovely in form and texture and are very fragrant. Although the plant does not mind hot weather, it does best in part shade under filtered sunlight with good drainage. $6 \mathrm{ft} .15^{\circ}$.

$5050-$ Gal. tins, $\$ 2.00$

\section{Callistemon Red Chico Firefall Bush}

With this showy plant in your garden, you'll have a real Fourth of July display, for the 4-inch flowers, in a brilliant, vivid shade of red, hang down from the arching branches like little, glowing, red fires. The plant grows 6 to 8 feet in height, is open and graceful in habit. It is really a hot number during the blooming season from April to July. Full sun. $15^{\circ}$. 4970-Gal. tins, $\$ 1.50 . \quad 4971-5$-gal. tins, $\$ 4.75$.

\section{Callistemon viminalis Scarlet Bottle Bush}

No plant will provide a magnificent show of brilliant scarlet color more easily than this tall, slender, semi-weeping, rapid growing shrub which covers itself in the spring with great masses of cascading scarlet blooms, 4 inches long. Grows easily anywhere. Full sun. $15 \mathrm{ft} .15^{\circ}$. $\quad 4975-$ Gal. tins, $\$ 1.25$. 4976-5-gal. tins, \$4.25.

\section{Cassia artemisioides Featbery Cassia}

The finely cut silvery-grey foliage makes a perfect background for the clear yellow sweet-scented flowers which look like big yellow bumble-bees perched all over the plant. It needs little water, likes plenty of sunshine, thriving in Arizona and other desert sections as well as near the coast. Full sun. $8 \mathrm{ft}$. $15^{\circ}$ 5055-Gal. tins, \$1.25. 5056-5-gal. tins, \$4.25.

Sweetly fragrant flowers of Brunfelsia, see page 41

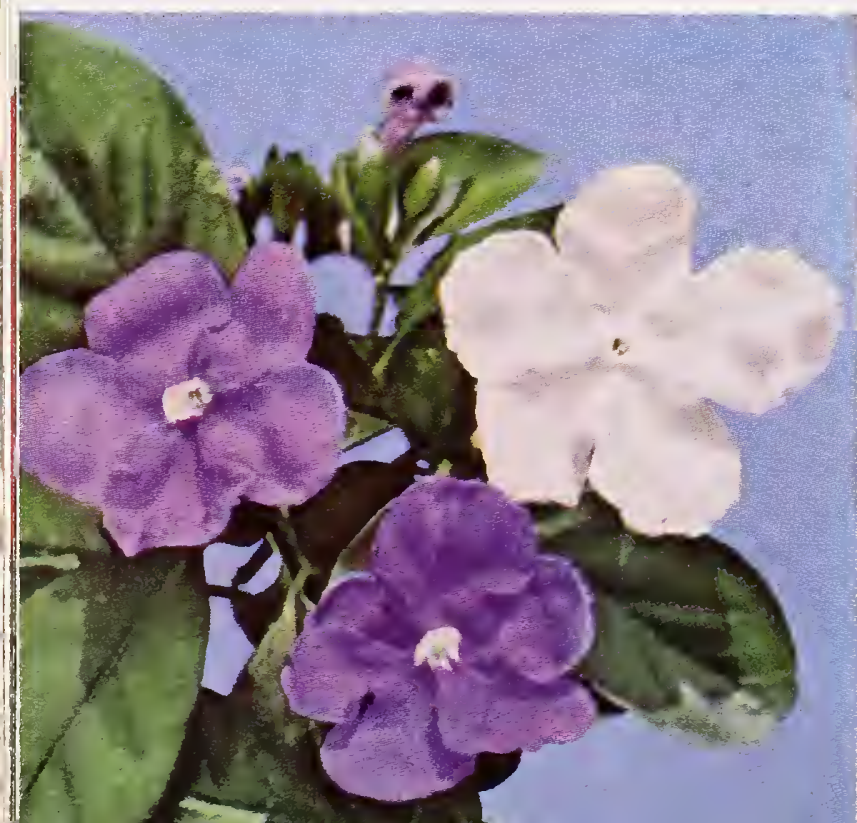

\section{Cassia splendida Golden Wonder}

We are very enthusiastic about this large shrub, which is spreading, much branched, and becomes 6 to 8 feet in height and as much across. From November to January it bears spectacular quantities of big golden yellow flowers at a time when it is difficult to get bright color in the garden. Does well both on the coast and inland. Although fairly large, it is compact in shape and fits into almost any sunny spot. $8 \mathrm{ft}$. Full sun. $20^{\circ}$.

$$
\text { 5060-Gal. tins, \$1.25. 5061-5-gal. tins, \$4.25. }
$$

\section{Ceratostigma willmottianum Chinese Plumbago}

A fine blue flowering shrub of medium size which never fails to produce a bounteous crop of flowers in the deepest and richest shade of blue you can imagine. It grows with ease anywhere in sun or shade and in any type of soil. Flowers continuously from June to December and is one of the very best blue flowered shrubs we know. In colder sections it drops its leaves in winter, but it should be pruned back wherever planted, anyway. 3 to $4 \mathrm{ft} .15^{\circ}$.

$$
\text { 5095-Gal. tins, \$1.50. 5096-5-gal. tins, } \$ 4.75 \text {. }
$$

\section{Ceratostigma plumbaginoides Dwarf Blue Plumbago}

A dwarf, spreading plant ( 6 to 8 inches) which is welcome anywhere in the garden for its flowers of intense blue. Blooms during summer and fall. See page 66 . Sun or semi-shade. $15^{\circ}$.
5090-Gal. tins, $\$ 1.00$. 


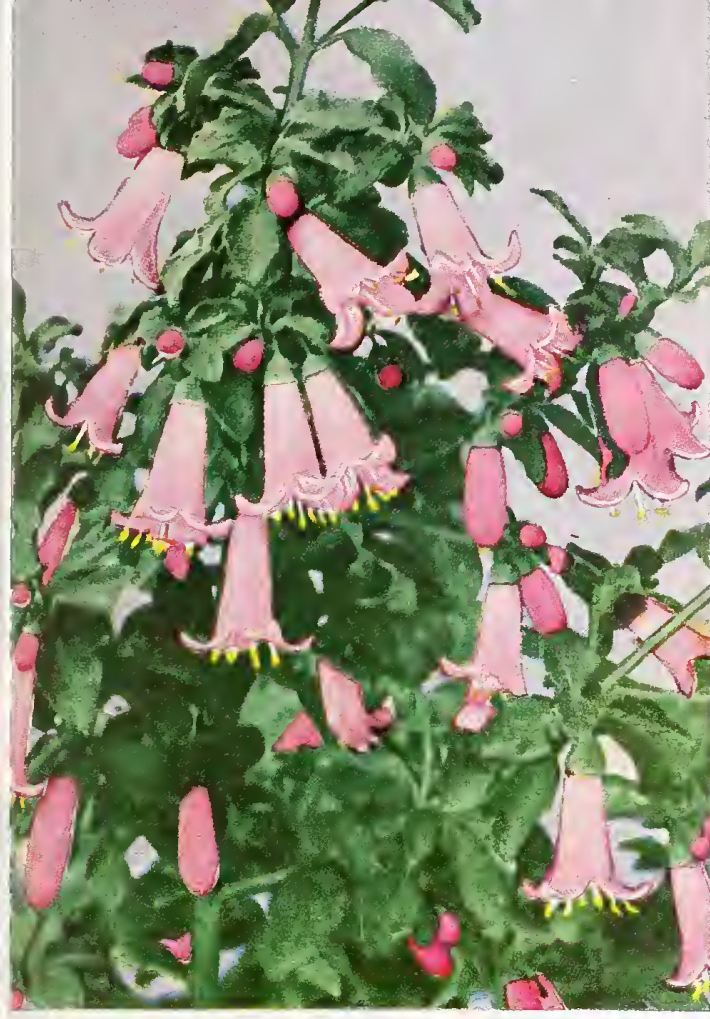

Australian Fuchsia (Correa pulchella)

\section{Daphne}

Daphne odora White Daphne

It is difficult to believe that such a delightful and intense fragrance could radiate from one small plant. The flower heads of creamy-white are borne profusely throughout the winter and they fill the garden with a delightful sweet perfume. The plant is a handsome one with shiny long green foliage; does best in partial shade with plenty of moisture but good drainage. 2 to $3 \mathrm{ft}$. $10^{\circ}$. $5360-$ Gal. tins, $\$ 3.50$ 5361-5-gal. tins, $\$ 10.00$

\section{Daphne odora Rose Queen} Large Pink-Flowered Daphne

This Daphne is much admired because the flowers, the glossy green foliage and the plant are all larger than those of other varieties. The deep pink flowers have all of that intense Daphne perfume 3 to 4 ft. $10^{\circ}$. $5365-$ Gal. tins, $\$ 3.50$ 5366-5-gal. tins, $\$ 10.00$

\section{Daphne odora Yellowedge}

Gold-Ed ged Daphne

The flowers are big, much like those of Rose Queen above, but each glossy bright green leaf is margined with gold. Partial shade, plenty of moisture, and good drain-

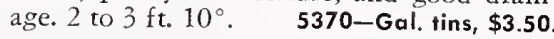
$5371-5$-gal. tins, $\$ 10.00$

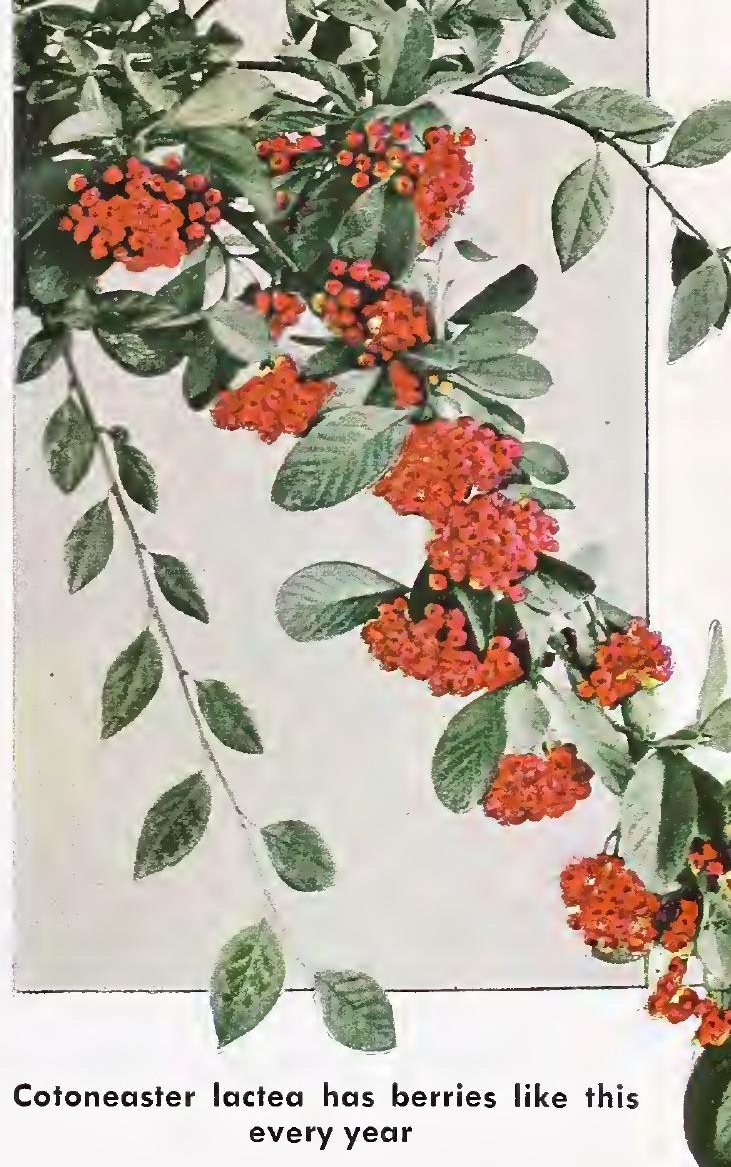

Dianella tasmanica Blue Dianella

In the spring, the 2-foot clump of grassy foliage produces spikes of brilliant, sky-blue flowers. They are followed by big $11 / 2$-inch oval berries of plum-blue. Both flowers and berries are fine for bowl arrangements. Part shade. $10^{\circ}$. 5385-Gal. tins, $\$ 1.50$

Duranta stenostachys Brazil Skyflower

Here is a beautifully foliaged, graceful arching plant which becomes about 5 feet high and as much across. Almost all summer long it bears attractive little 4 to 6 -inch sprays of lovely lilac-purple blooms, each one a half inch across. Sun or half-shade. 4 to $6 \mathrm{ft}$. $24^{\circ}$

$$
\text { 6700-Gal. tins, } \$ 1.25 \text {. 6701-5-gal. tins, } \$ 4.25 \text {. }
$$

\section{Echium fastuosum Pride of Madeira}

Each plant makes a large clump of interesting foliage 3 or 4 feet high and 4 feet across. Rising from the plant in June are enormous blue flower spikes. Likes an open warm sunny location where drainage is good. See illustration on page $46.15^{\circ}$. 5415-Gal. tins, $\$ 1.50$.

\section{Elaeagnus pungens Fruitland}

Fruitland Silverberry A large spreading shrub with the 4-inch leaves and the stems covered with frosty shiny scales. Even the great silver-bronze berries look as though they had been gilded. Thrives anywhere, even in the ocean spray. Sun or part shade $8 \mathrm{ft} 10^{\circ}$

5420-Gal. tins, \$1.50. 5421-5-gal. tins, \$4.75

Golden-yellow flowers of Cassia splendida-see page 42

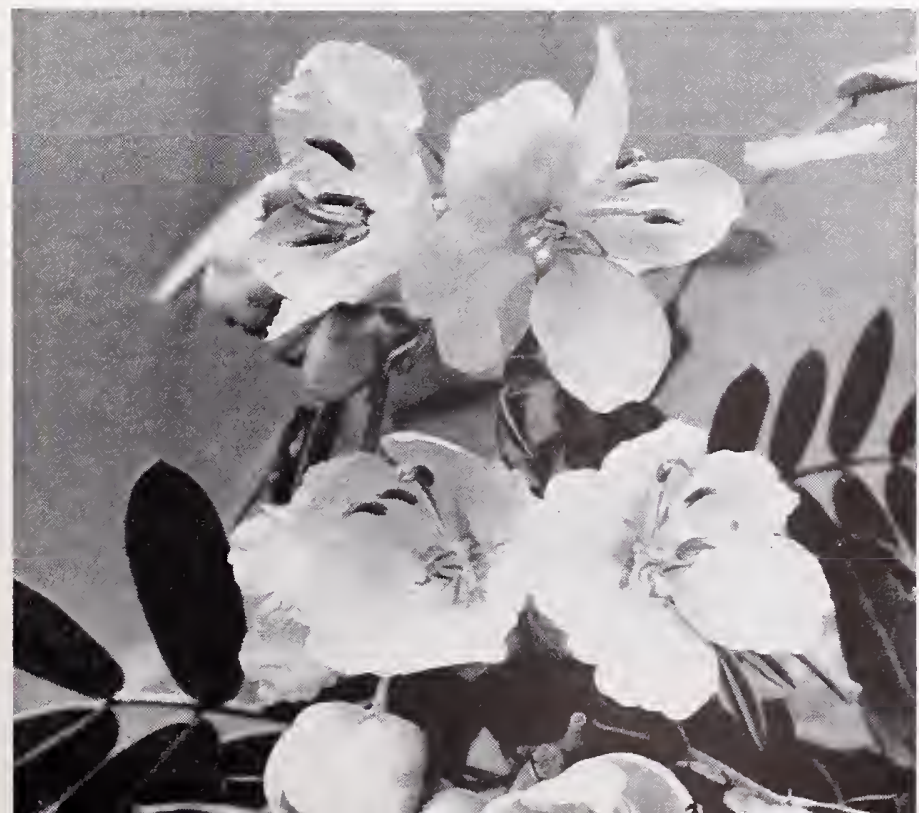

\section{Eranthemum nervosum Blue Winter Eranthemum}

We are always very much pleased when we can recommend a good small blue flowering shrub because they are scarce, especially one which has such luxuriant-looking all-year foliage. This plant from tropical India bears many large clusters of the most brilliant blue flowers throughout the late winter and spring. Sun or part shade. Plenty of moisture. $4 \mathrm{ft} .24^{\circ}$.

6705-Gal. tins, $\$ 1.50$.

\section{Escallonia rubra Red Escallonia}

Escallonias will take the salt air and their splendid foliage is particularly luxuriant under coastal conditions. The Red Escallonia produces over most of the year sweetly fragrant spikes of deep red flowers. Plant in sun or part shade. Plenty of water. $6 \mathrm{ft} .15^{\circ}$

5460-Gal. tins, \$1.25. 5461-5-gal. tins, \$4.25.

\section{Escallonia viscosa Apple Blossom \\ Apple Blossom Escallonia}

Like Escallonia rubra described above, this variety has the same glossy bright green foliage but the leaves are considerably smaller. Throughout the year the plant produces very fragrant flowers of dainty blushpink. Grows more slowly, a little lower, and more compactly than Escallonia rubra. $5 \mathrm{ft} .15$

5465-Gal. tins, \$1.25. 5466-5-gal. tins, $\$ 4.25$.

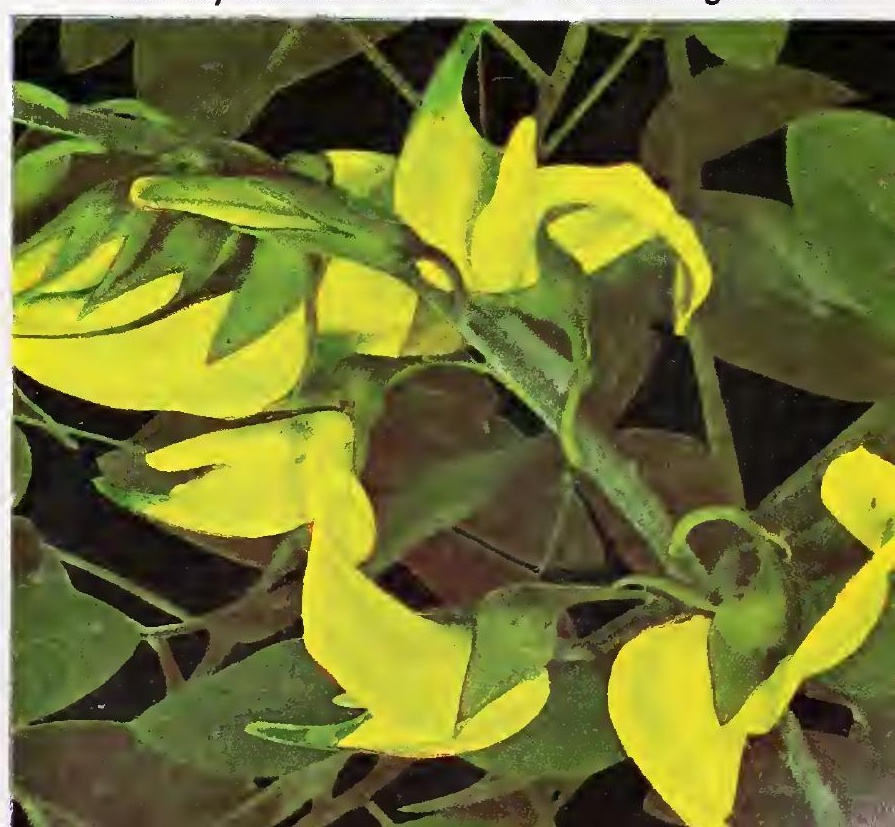




\section{Euphorbias Poinsettias}

Euphorbia pulcherrima The well-known scarlet "Christmas Flower" so popular in milder sections. Always be sure to plant in full sun. $28^{\circ}$. 3090-Gal. tins, $\$ 1.25$.

Euphorbia Henriette Ecke Improved Giant Peony-Flowered Poinsettia. A striking poinsettia, fully double like a peony. Giant in size, and a brilliant scarlet, they get 9,10 , or even 12 inches across. $28^{\circ}$. 3100-Gal. tins, \$1.25.

\section{Euonymus japonicus}

E'ergreen Euonymus

Resistant to heat and cold, the dense glossy foliaged plant makes a very useful ornamental. May easily be pruned as a hedge or a specimen plant. 5510-Gal. tins, $\$ 1.00$. $5512-$ Flats of 100 plants, $\$ 8.50$. 6950 -Balled, $11 \frac{2}{2}$ ta $2 \mathrm{ft}$., $\$ 6.00$. 6951 -Balled, 2 ta $21 / 2 \mathrm{ft}$., $\$ 7.00$. $6952-$ Balled, $21 / 2$ ta $3 \mathrm{ft}$., $\$ 8.50$.

\section{Eugenia paniculata australis}

Australian Brusb Cherry

This popular foliage plant will reach 12 or 15 feet in height, but it is usually pruned lower as a single pyramidal specimen or as a hedge. Its clean, shiny, good-looking foliage is attractive throughout the year and the big purple berries make excellent jelly, too. The new Eugenia Armstrong is better if your space is limited. $24^{\circ}$

$6720-$ Gal. tins, $\$ 1.00$. 6721-5-gal. tins, $\$ 3.75$ $6722-T r i m m e d$ pyramids, $5 . \mathrm{gal}$., 6 ta $8 \mathrm{ft}$., $\$ 7.50$ 6723-Trimmed pyramids, tub, 6 to $8 \mathrm{ft.,} \$ 10.00$

\section{Euryops athanasiae}

Soutb African Daisy Bush

The tall, slender evergreen plant carries big, bright yellow daisy-like flowers, 8 inches across, on long stems in mid-winter. Full sun. $18^{\circ}$

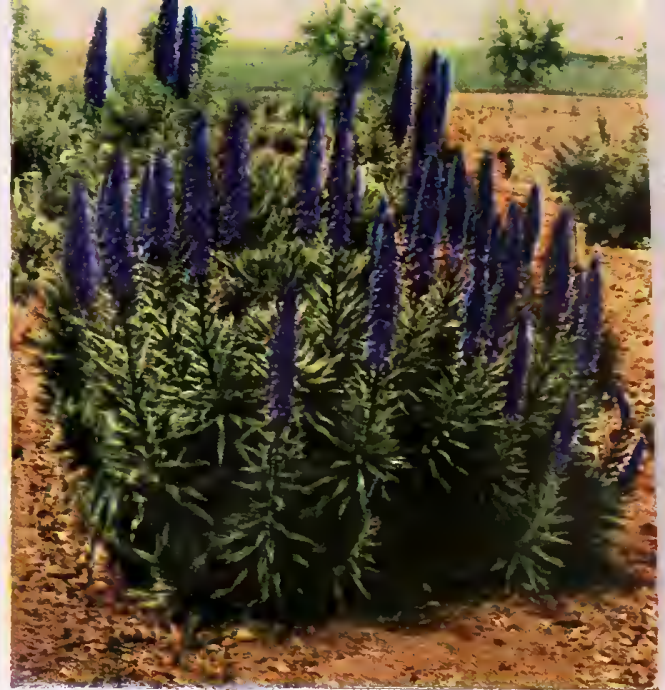

Echium fastuosum (see page 45)

\section{New Dwarf Eugenia}

\section{Eugenia Armstrong}

The handsome Eugenia australis is just about the most widely planted shrub of its kind in California. Some years ago a new strain of this popular variety was discovered in our fields, and now after thorough tests we are happy to be able to offer it to you-happy because for the first time we have a Eugenia which will fit many garden spots unsuited to the older and much larger growing Eugenia australis. Smaller foliage of a darker green emphasizes the neat, compact habit of the plant, but it still retains the shiny glossiness throughout the year which makes the Eugenia so popular. Just like the mature plant pictured at the lower right of the next page, you will find that this one will stay compact and good-looking year after year in your garden with very little pruning. Plant Pat. No. $1037.5 \mathrm{ft} .24^{\circ}$

$$
6715-G \text { al. tins, } \$ 1.50 \text {. } 6716-5-\text { gal. tins, } \$ 4.75 \text {. }
$$

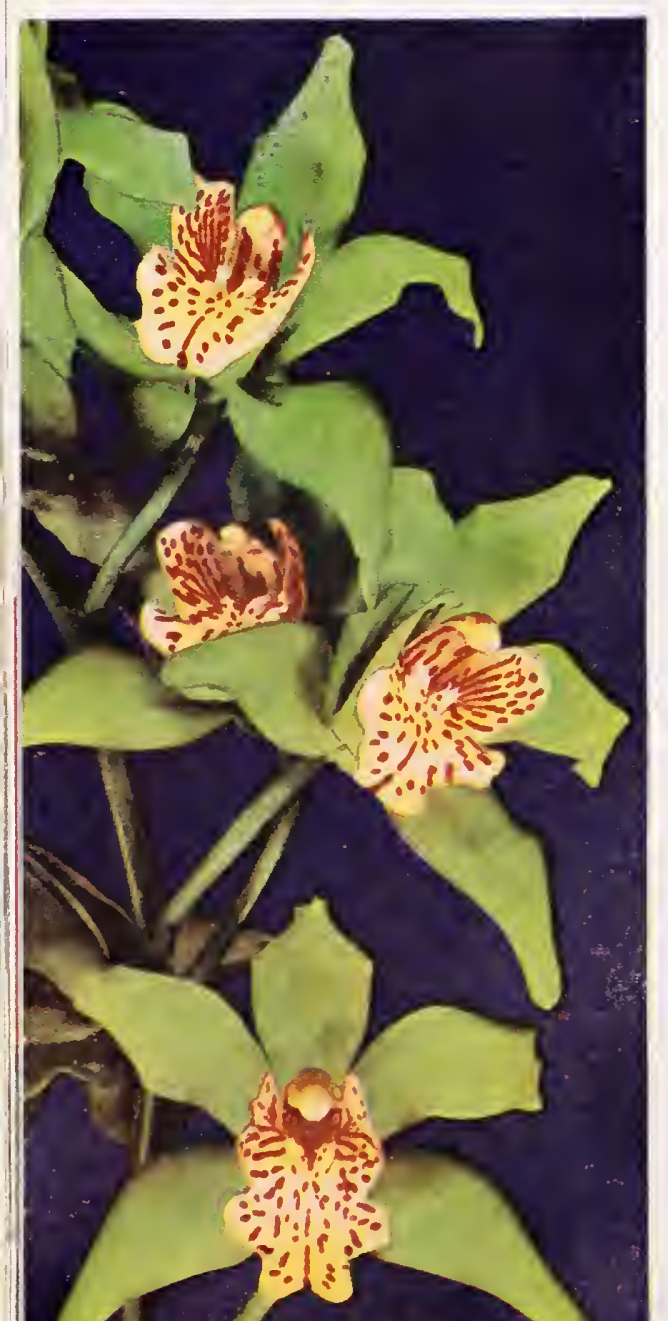

\section{Fatshedera lizei}

Something rare in nature, an artificial hybrid between the giantleaved Fatsia japonica and the English Ivy. The plant is halfway between the two with extremely handsome, deep green, glossy foliage. Makes a good rounded compact shrub, or is excellent for training flat against a wall, or for planter use. Sun or shade. $6 \mathrm{ft}$. $5^{\circ}$ $5521-$ Gal. tins, $\$ 1.50$.

\section{Fatsia japonica}

The giant, 12 -inch lobed leaves of bright shining green create a lush tropical effect. One of the best of the bushy large foliaged plants which fit so well into the landscaping of modern California homes. 4 to $8 \mathrm{ft} .15^{\circ}$. 5523-Gal. tins, $\$ 1.25$. 5524-5-gal. tins, $\$ 4.25$.

\section{Fremontia mexicana San Diego Fremontia}

A large native shrub with attractive grey-green foliage and a graceful spreading habit. In late winter and spring it is covered with masses of 3 -inch golden yellow flowers. Plant it in full sun with good drainage. Give it little water and not much attention. Eventually grows to 15 or $20 \mathrm{ft} .12$ $5630-$ Gal. tins, $\$ 2.50$.

\section{Exotic Garden Orchids}

These spectacular orchids grow well along the coast, from San Diego to San Luis Obispo, and in all inland valleys except desert areas. Plant them in filtered sunlight and in a fibrous soil, mixed with plenty of coarse leaf mold or peat moss. They grow particularly well in pots, but wherever planted, they must have good drainage. $28^{\circ}$.

We cannot guarantee specific colors as they vary considerably in the same varieties.

All varieties belaw in 6-inch pats, $\$ 4.50$ each; any 3 plants af yaur choice, $\$ 11.50$.

Cymbidium Butterfly Shades of yellow, bronze or mahogany, with an occasional pink. Midseason. 5307.

Cymbidium Capella Varies from pink to crimson-rose. Large, many flowers to the spray. Midseason. 5308 .

Cymbidium Gold Mohur A striking yellow flower varying somewhat in tone but always with a blush of claret. Midseason. 5316.

Cymbidium Hugh Evans Usually greenish gold with red lips. Mid to late. 5317.

Cymbidium Jessica Solid pink in varying tones, always lovely. Midseason. 5319.

Cymbidium Madeline Quite variable. Deep pink or chartreuse. Midseason. 5322.
Cymbidium Merlin Varies considerably from deep pink to yellow. Late. $\mathbf{5 3 2 3 .}$

Cymbidium Pauwelsi Varies from light creamy yellow to deep rich bronze. A strong grower with long spikes. 5326.

Cymbidium Penelope Light to dark greenish buff shaded rose; red lips and lighter throat. Mid to late season. $\mathbf{5 3 2 7}$.

Cymbidium Plover Variable but always a pleasing combination of green to bronze and brown tones. Midseason. 5328.

Cymbidium Victor Varying tones of yellow and bronze. Free blooming. 5332.

Cymbidium Wheatear Quite variable but mainly straw color. Mid to late. 5333. 


\section{Heathers for Winter Bloom}

Erica blanda Red Ev'erblooming Heatber

A low rounded plant, with a compact habit and typical heather foliage. It produces clusters of tubular red flowers throughout the entire year. What flowering shrub will do more? Full sun. $3 \mathrm{ft} .15^{\circ}$ 5425-Gal. tins, \$1.75. 5426-5-gal. tins, $\$ 5.25$.

\section{Erica cruenta Duarf Scarlet Heather}

A bushy low-growing plant with 6 to 8-inch spikes of slender, tubular, flame-red flowers throughout the fall and winter. $3 \mathrm{ft} .18^{\circ}$. 5440-Gal. tins, $\$ 1.75$

Erica canaliculata rosea Rosy Christmas Heather This is the most popular and best known of all heathers in California, and it is certainly one of the most beautiful of all of our winter flowering shrubs. From November to March the plant is a solid mass of small rosy lavender flowers dotted with black stamens. They are displayed to good advantage against the finely cut, heath-like foliage. It is sometimes called "Scotch Heather" but it never saw Scotland, for it is a native of South Africa. Likes to be planted in full sun with good drainage. 6 to $8 \mathrm{ft}$. $12^{\circ}$. $\quad \mathbf{5 4 3 0 - G a l . ~ t i n s , ~} \$ 1.50$ $5431-5$-gal. tins, $\$ 4.75$ 6946-Balled, 3 to $4 \mathrm{ft}$., $\$ 7.50$

Erica lusitanica SpanisbHeatber

So covered in late winter with snowy white flowers that it looks like a young snow drift. Three or four plants massed together are especially effective for showy winter bloom. $4 \mathrm{ft}$. $18^{\circ}$. 5445-Gal. tins, $\$ 1.50$.

\section{Erica mediterranea Biscay Heath}

A compact and bushy heather with stiff stems and purplish pink flowers from March to June. Grows easily almost anywhere. $4 \mathrm{ft} .5^{\circ}$ $5450-$ Gal. tins, $\$ 1.50 . \quad 5451-5$-gal. tins, $\$ 4.75$.

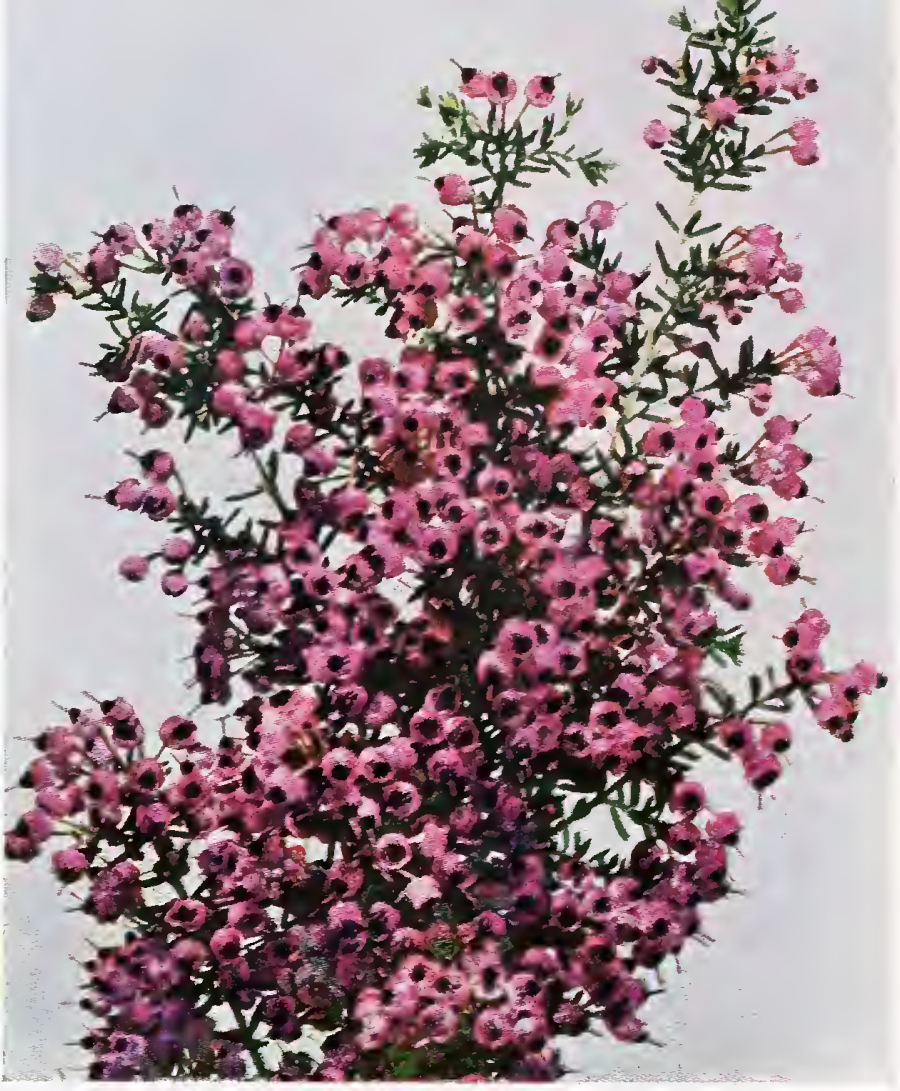

Erica canaliculata rosea is loaded with bloom just like this at Christmas time

\section{Freeblooming Fuchsias}

No other shade-loving shrubs bloom so profusely and over such a long season as the fuchsias. They like a cool, moist, shady place and are hardy to $22^{\circ}$.

\section{Upright Growing Fuchsias}

Aviator Single pure white, with long rose-red sepals. 2 to $4 \mathrm{ft} .3115$.

Blue Gown A brilliant blue cup in a bright scarlet saucer. Large double, 3 to $4 \mathrm{ft}$. 3120 .

Cardinal Sepals deep rose to cardinal-red, with purple petals. Climbs to 15 feet. 3125 .

Glendale Dainty coral-pink flowers. Stands full sun on coast. 4 to $5 \mathrm{ft}$. 3140 .

Gypsy Queen Double, large, with rose-pink petals and flame-colored sepals. Low growing. 3145 .

Little Beauty Single purple petals, red sepals. Plant compact, blooms heavily. 1 to $2 \mathrm{ft}$. 3150

Melody Large, single flowers with cup of pale purple and saucer of rose. 2 to $4 \mathrm{ft} .3155$.

Mrs. Lovell Swisher Fast growing, cascades of small flowers with petals of rosy red, sepals white shaded light pink. 3 to $4 \mathrm{ft} .3160$.

Otto A brilliant purple cup (the petals) in a bright scarlet saucet (the sepals). 4 to $5 \mathrm{ft}$. 3165 .

Pasadena Small, semi-double, white with striped pink petals and deep pink sepals. Densely foliaged plant. 6 to $8 \mathrm{ft}$. 3170 .

\section{Colorful Geraniums}

Geraniums and pelargoniums botanically are one and the same, although most of us associate pelargoniums with the famous Martha Washingtons. Among the new hybrids of the Martha Washington type are some of the most beautiful flowers imaginable in breath-taking color combinations. These colorful, new, giant-flowered strains are just as free-blooming as the more familiar older kinds and you seldom see them, even in midwinter, without plenty of lovely flowers. You can see them in our display yards in full bloom from about the first of April until late fall.

Pasteur Double, with white petals; scarlet sepals. 1 to $2 \mathrm{ft} .3175$.

Pride of Orian Immense double white with petals pure white, sepals scarlet. 4 to $5 \mathrm{ft} .3180$.

Souv. de Henry Henkel Long, tubular, scarlet flowers and plumcolored foliage. 2 to $4 \mathrm{ft}$. 3185 .

Storm King Petals waxy white, with crimson veins at the base, brilliant scarlet. Quite double. 3 to $4 \mathrm{ft} .3190$.

\section{Hanging Basket Fuchsias}

Aurora Superba. Single, orange-salmon. 2 to $4 \mathrm{ft} .3110$.

Cascade A lovely combination of coral-rose sepals and bright rosepink petals. 1 to $2 \mathrm{ft}$. 3130 .

\section{New compact Eugenia Armstrong}

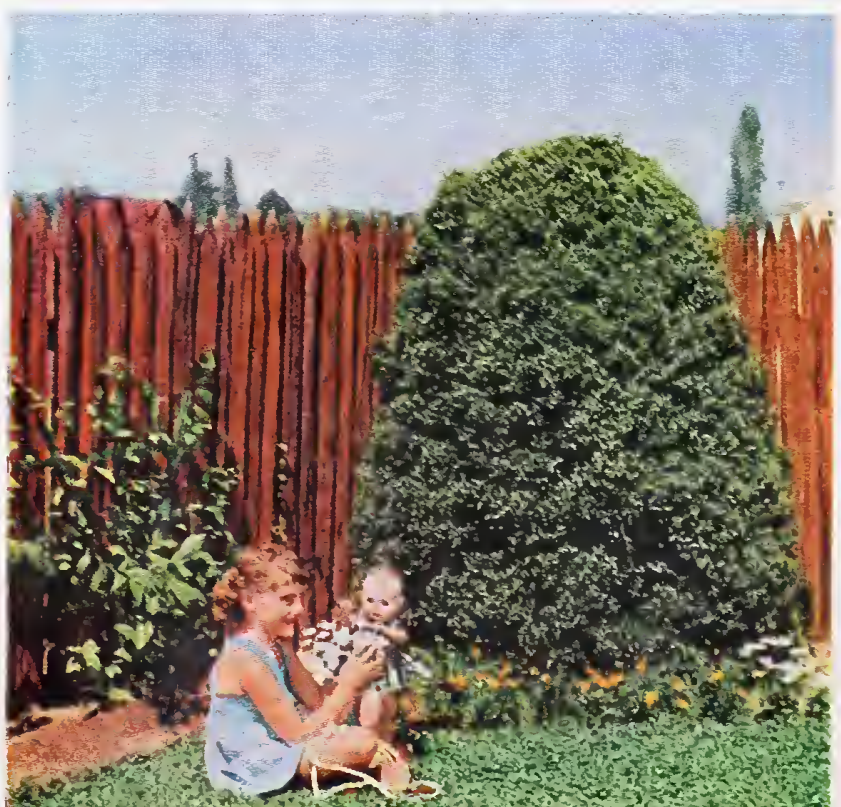




\section{Armstrong Hibiscus}

The hibiscus is one of the showiest shrubs for Southern California. The fast-growing plants are always covered with huge, shiny, freshlooking leaves and throughout the year there is always a remarkable show of the immense, brightly colored, exotic flowers. The plants like plenty of sunshine and moisture and are at their best in coastal regions. They will thrive in the foothills and interior valleys where the temperatures do not get too low. The varieties listed here are hardy to about $29^{\circ}$ and are all single unless otherwise noted in the description.

\section{Standard Varieties}

All standard varieties, gal. tins, $\$ 1.25 ; 5$-gal. tins, $\$ 4.25$.

\section{Agnes Galt}

The huge deep coral-pink flowers of this strong growing variety have long been a favorite with California gardeners. Out-blooms all others. 3210-Gal. tins. $3211-5$-gal, tins.

\section{Brilliante}

Immense brilliant scarlet. No other red Hibiscus can beat it. It blooms prodigiously and is the hardiest of the lot, grows almost anywhere

\section{Bronzino}

3230-Gal, tins. $3231-5$-gal. tins.

The entire flower, almost 6 inches across, is a brilliant orange-bronze with a tinge of red in the center. 3240-Gal. rins. 3241-5-gal. tins.

\section{Double Yellow}

Large, many-petaled flowers of clear yellow without other shadings. 3290-Gal. tins. 3291-5-gal, tins.

\section{Fireside}

A magnificent, richly colored hibiscus from Hawaii. The 5-inch flower has broad overlapping petals, flaming red at the center, suffusing toward a deep yellow at the outer edge.

3300-Gal, tins. 3301-5-gal. tins.

\section{Hallowe'en}

Can you recall the rich orange-scarlet of a ripe Hachiya Persimmon? That is the color that covers the greater portion of the petals of this hibiscus. This brilliant tone merges into copper and shining gold. Plant Pat. 698. 3310-Gal. tins. 3311-5-gal. tins.

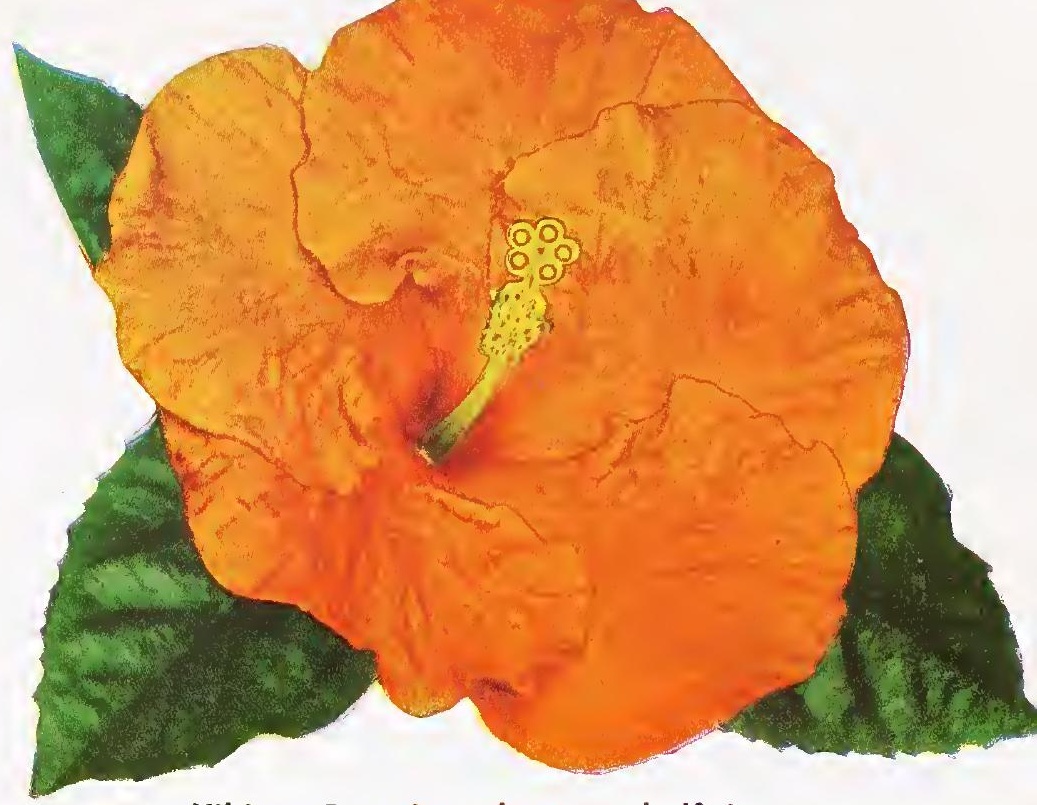

Hibiscus Bronzino, about one-half size

\section{Kona}

A fully double flower with daintily frilled petals of warm rosy pink and deeper rosy stamens. Golden anthers dot the center. 3320-Gal, tins. $3321-5-g a l$, tins.

\section{Red Monarch}

A very large, double flower of dark rich crimson. The many petals are gracefully arranged. $3330-$ Gal. tins. $3331-5$-gal. tins.

\section{Sophisticate}

Big white ruffled petals are perfectly arranged to make a big symmetrical wide flaring flower. Each petal is heavily blushed with deep pink at the base and the whole effect is very lovely, indeed. 3340-Gal. tins. 3341-5-gal. tins.

\section{Sunshine}

Big flowers of golden yellow with a deep pink throat. The plant is a vigorous grower, producing many flowers.

$$
\text { 3360-Gal. tins. 3361-5-gal. tins. }
$$

\title{
Newer Exotic Hibiscus Varieties
}

\author{
All varieties below: Gal. tins, $\$ 1.75 ; 5$-gal. tins, $\$ 5.25$.
}

\section{Arnottianus}

A very unusual flower and one of the loveliest of all hibiscus. The flowers are snowy white with no other color except the long flaming red pistil which dots its center like a ruby. Blooms heavily and the flowers are delicately fragrant. 3220-Gal. tins. 3221-5-gal. tins.

\section{Crimson Tide}

A prized variety from one of Hawaii's outstanding collections. The flowers are exceedingly large, yet the broad petals do not curl annoyingly as they do in so many of the large-flowered types. Few flowers have such spectacular coloring, a vivid crimson, shading to darker red at the center. A big, vigorous plant keeps the showy blossoms coming along continuously. 3270-Gal. tins. 327l-5-gal. tins,

\section{Crown of Bohemia}

The most spectacular double hibiscus that we have ever seen, and many must agree, because it is in great demand and we never have enough. Enormous many-petaled bronzy orange flowers actually seem iridescent with tints of cerise, apricot, and amber at the center of the bloom. 3280-Gal. tins. 3281-5-gal. tins.

\section{Waikiki}

More often than not, Hibiscus which display huge uniquely colored flowers, such as the new Waikiki, produce fewer of them. This one blooms freely, and the giant wide flaring flowers with their ruffled overlapping petals are truly breath-taking. The color is a deep rich bronzy-orange, shading to vivid-scarlet at the throat-a glowing combination which will attract plenty of attention.

$$
3370-G \text { al. tins. } 3371-5-\text { gal. tins. }
$$

Even thougb occasional beavy frosts will damage the tops of bibiscus plants severely, it is not permanent in most cases. They grow v'ery rapidly and recover quickly.

\section{Stoplight}

The wide flaring petals overlay one another perfectly and the huge flower of brilliant cerise red fairly sparkles. Because of its striking color, size and perfection, Stoplight is one of the best red kinds. 3350-Gal. tins. 3351-5-gal. tins.

The vividly colored Stoplight

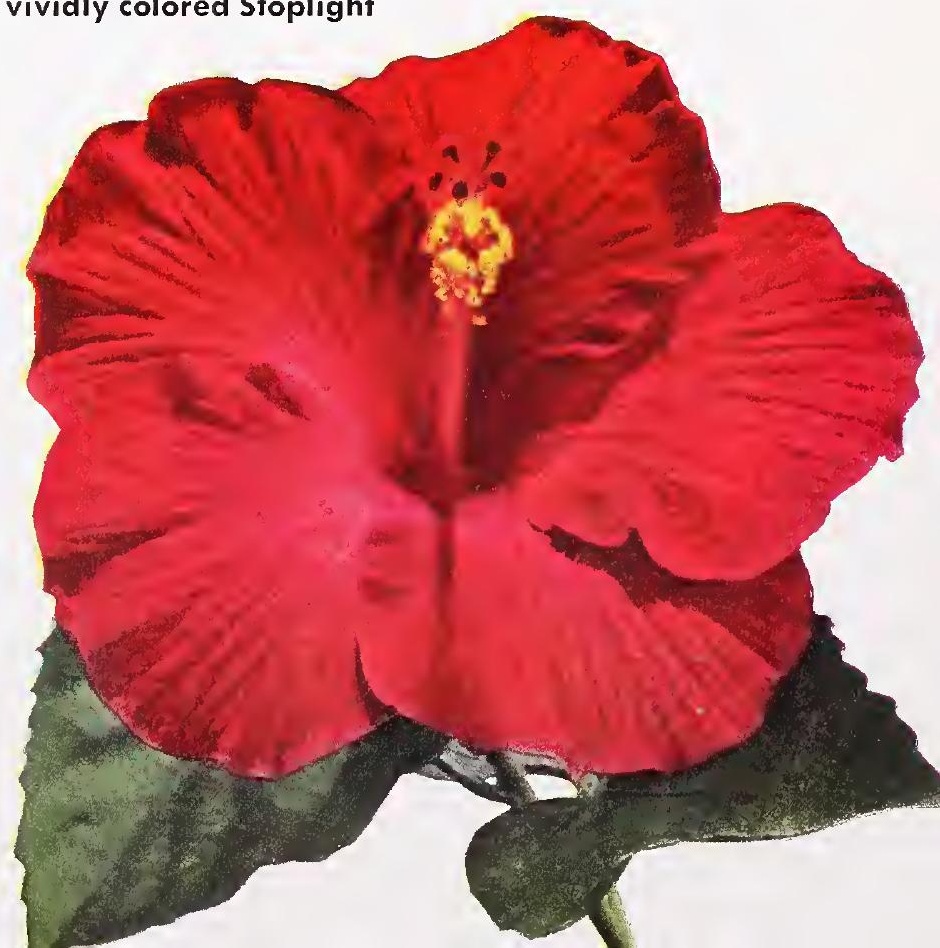




\section{Evergreen Shrubs}

Hedychium gardnerianum Orange Ginger-Lily

For something really startling in the way of exotic color and fragrance, try this new Ginger-Lily from India. The 8 to 12 -inch flower spike is a complicated affair with long tubes of saffron-yellow, contrasted with long filaments which are orange, shading to orange-scarlet at the top. See illustration, below. It has an intoxicating sweetness which fills the garden with fragrance or the house it you want to cut the spikes. It blooms with great freedom in summer and fall. Plenty of moisture. Sun or shade. 4 to $5 \mathrm{ft}$. $24^{\circ}$. $6750-$ Gal. tins, $\$ 2.50$. 6751-5-gal. tins, $\$ 7.50$.

\section{Hedychium coronarium White Ginger-Lily}

Similar to the above but with exceedingly fragrant 3 -inch white blossoms, used by the ladies in the South Sea Islands for their leis. The fragrance is extremely powerful. It likes good soil and you can't give it too much water. Sun or part shade along the coast, part shade inland. $6 \mathrm{ft}$. $24^{\circ}$. 6745-Gal. tins, $\$ 1.75$. 6746-5-gal. tins, $\$ 5.25$.

\section{Holmskioldia sanguinea Chinese Hat Plant}

In a warm, sunny spot, this unique plant will produce great long clusters of bright red flower bracts, during almost the entire year, even through the middle of winter when you can use it for Christmas decorations. A beautiful thing when trained flat against buildings or wall facing south. It likes plenty of sunshine and water. $8 \mathrm{ft}$. $22^{\circ}$.

5805-Gal. tins, $\$ 1.50$.

\section{Hypericum moserianum Gold Flower}

A particularly valuable low foreground shrub, covered in early spring and summer with big 2-inch golden yellow flowers. Easy to grow anywhere. Full sun or part shade. $2 \mathrm{ft} .10^{\circ}$. 5850-Gal. tins, \$1.25.

\section{Hypericum patulum henryi Henry's Golden Cup} Plenty of bright golden 2-inch flowers like the above, but it gets up to 4 feet in height and makes a beautifully rounded, compact plant blooming over most of the spring and summer. Grows with the greatest of ease in any soil. Sun or part shade. $4 \mathrm{ft} .10^{\circ}$

5855-Gal. tins, \$1.25.

\section{Itea ilicifolia Holly-Leaf Sweetspire}

The big-toothed polished, dark green leaves look more like Holly than even Holly itself. You will never find anything better than its foliage to use for your Christmas decorations. Holly-Leaf Sweetspire is one of the most magnificent foliage plants for any California garden. Grows tall and slender. Plant in sun or part shade along the coast, but only part shade inland. $8 \mathrm{ft} .15^{\circ}$.

$$
5885-\text { Gal. tins, } \$ 1.50 \text {. } \quad 5886-5 \text {-gal. tins, } \$ 4.75 \text {. }
$$

\section{The Hollies}

\section{llex cornuta Burford}

Burford Holly

With its large, glossy, deep green foliage, this is one of the finest hollies for Southern California. Every year the plants will bear plenty of big, bright red berries like those illustrated above. Generally they are even larger and more showy than the berries on the familiar English Holly. The plant has a rather neat, compact habit and although it will eventually make a big shrub, it will not reach its ultimate height for many years. This variety will grow well in sun or shade. 6 to $10 \mathrm{ft} .10^{\circ}$.

5875-Gal. tins, $\$ 2.00$. 5876-5-gal. tins, $\$ 6.00$. 6955 -Balled, 2 to $3 \mathrm{ft}, \$ 7.50$.

6956-Balled, 3 to 4 ft., $\$ 10.00$.

\section{Ilex cornuta Fertile}

Fertile Chinese Holly

This is one of the best Hollies for California because it is more adapted to warmer climates than the English Holly. You can grow it right out in the sun in most parts of the State. The magnificent big dark green spiny leaves make one of the most beautiful plants that can be grown. These are cutting-grown from a special heavy berryproducing type. 5 to $6 \mathrm{ft} .10^{\circ}$.

$5880-$ Gal. tins, $\$ 2.00$. $5881-5$-gal. tins, $\$ 6.00$. 6960 -Balled, 2 ta $3 \mathrm{ft}, \$ 7.50$ $6961-$ Balled, 3 to $4 \mathrm{ft}$., $\$ 10.00$.

\section{Jasminum sambac Grand Duke}

A rare and beautiful, semi-reclining shrub with double 3 -inch flowers of pure white. It has a powerful and refreshing sweet perfume. Quite hardy, but prefers some shade and blooms almost the year around. The flowers look like perfect many-petaled gardenias and exceed gardenias in the intensity of their sweet perfume. Part shade. 2 to 5 ft. $22^{\circ}$.

$3380-$ Gal. tins, $\$ 2.50$

\section{Jasminum sambac Maid of Orleans}

Closely related to the jasmine above, since they are both forms of the Arabian Jasmine. This one grows much faster than Grand Duke and makes a bushy, upright plant, carrying in the late summer and fall dozens of the little, creamy white, double flowers 1 to $11 / 4$ inches across. The flowers are heavy with sweet, rich jasmine fragrance. Carries many more flowers than the Grand Duke Jasmine, although they are smaller. Plant in part shade. 3 to $6 \mathrm{ft} .24^{\circ}$. 3390-Gal. tins, $\$ 2.00$.

\section{Lavandula officinalis Lav'ender}

Every time you pass the neat, rounded clump of silvery grey foliage you will pick a leaf or two and rub it between your fingers to enjoy the clean aromatic fragrance. The tall rosy purplish flower spikes are even more fragrant than the foliage and they last for a long time when cut. Easy to grow. Full sun. 2 to $21 / 2 \mathrm{ft}$. $5^{\circ}$.

5965-Gal. tins, $\$ 1.00$. 6995-Balled, 12 ta 18 in., $\$ 3.00$.

\section{Ilex aquifolium Fertile}

Fertile English Holly

Many English Hollies grown from seed do not produce berries. These special grafted plants are of a type which bear heavy crops of large red berries every year. In Southern California English Holly should be planted in shade or semi-shade. In other areas where winter temperatures are low enough so that English Holly does well, it can be planted in full sun. Always needs plenty of moisture. 8 to $10 \mathrm{ft}$. $5^{\circ}$.

5865-Gal. tins, $\$ 2.00$. $5866-5$-gal. tins, $\$ 6.00$.

\section{Ilex aquifolium Silver Queen}

Silv'er-Edged English Holly

Special grafted plants of the familiar English Holly-the foliage will always be beautifully variegated, silver and light green. $5^{\circ}$

$5870-$ Gal. tins, $\$ 3.00$

\section{Ilex altaclarensis Wilson}

Broad-Leat'ed Holly

The glossy typically holly leaves of this type are the biggest of any variety in our collection (sometimes 4 in. long). It makes a compact, magnificent shrub and the beautiful, big red berries are on a par with the handsome foliage. Shade or part shade in Southern California, sun in the North. 6 to $8 \mathrm{ft} .5^{\circ}$

5860-Gal. tins, $\$ 2.00$. $5861-5$-gal. tins, $\$ 6.00$.
The very fragrant flower spikes of the Orange Ginger-Lily (Hedychium gardnerianum)

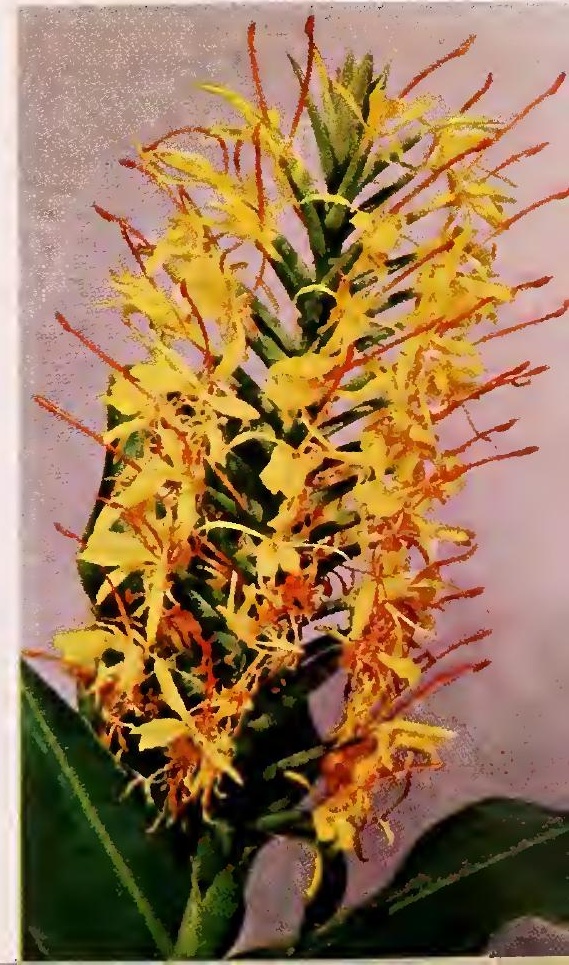




\section{Evergreen Shrubs}

Myrtus communis True Myrtle

Valuable for either single specimens or hedge. Foliage is shiny green and highly aromatic. Has creamy white flowers in spring followed by black berries. Does well anywhere. 4 to $8 \mathrm{ft} .15^{\circ}$. $6150-G$ ol. tins, $\$ 1.00$.

$6151-5-$ gol. tins, $\$ 3.75$. $\quad 6152-$ Flats of 100 plonts, $\$ 8.50$.

\section{Myrtus communis Compact Dwarf Myrtle}

One of the finest low-growing plants we have, either for a hedge or a single rounded specimen. Stays extremely dense and compact. Its small dark shining leaves are green and fresh looking throughout the year. Easily grown almost anywhere in California or Arizona. 3 to $6 \mathrm{ft} .15$ 6155-Gol. tins, $\$ 1.00$ $6156-5$-gol. tins., $\$ 3.75$. $\quad 6157-$ Flats of 100 plants, $\$ 8.50$.

Note: Armstrong Myrtles are cutting-grown and are therefore uniform in size and shape.

\section{Nandina domestica Heavenly Bamboo}

A very useful ornamental plant either as a single specimen or for a hedge. The dense covering of compound leaflets is bronzy-red when young, turning to dark red at maturity. The entire plant turns to a rich coppery-red during the winter. Late in the year the plant displays clusters of bright red berries, but you must have more than one plant if you want berries. Sun or part shade. $5 \mathrm{ft}$. $0^{\circ}$. 6160-Gol. tins, \$1.25. $6161-5-g o l$. tins, $\$ 4.25$.

Brilliant berries of Pyracantha Graber, shown like this at Christmas-time

\section{Nerium Oleander}

The oleander with its good-looking evergreen foliage and its continuous show of colorful blooms is a beautiful shrub anywhere in California. It does particularly well in the desert areas, but it is right at home immediately along the seacoast as well. It grows and blooms very quickly wherever planted and makes a good tub plant, too. Prices on all varieties: Gol. tins, $\$ 1.25$ 5-gal. tins, $\$ 4.25$. Lorge bolled plants availoble as indicated.

Double Solmon (Mrs. Roeding). 6180-Gol. tins. 6181-5-gol. tins. 7046-Bolled, 3 to $4 \mathrm{ft}$., $\$ 7.50$. $7047-$ Balled, 4 to $5 \mathrm{ft}$., $\$ 9.00$

Double Rose-Pink. 6175-Gol. tins. 6176-5-gal. tins.

7042-Bolled, 4 to $5 \mathrm{ft}$., $\$ 9.00$. 7043-Balled, 5 to $6 \mathrm{ft}$., $\$ 11.00$.

Double White. 6185-Gal. tins. 6186-5-gol. tins.

Single White. 6195-Gal. tins. 6196-5-gol. tins.

7052-Balled, 4 to $5 \mathrm{ft}$., $\$ 9.00$. 7053 -Bolled, 5 to $6 \mathrm{ft}$., $\$ 11.00$

Single Red (Cherrytime). Much deeper in color than Double Rose-Pink.

$6170-$ Gol. tins. 6171-5-gol, tins. $7039-$ Bolled, 3 to $4 \mathrm{ft}$., $\$ 7.50$. 7040-Bolled, 4 to $5 \mathrm{ft}$., $\$ 9.00$

Single Large Pink (Pink Beauty). A light shade of pink with extra large flowers. 6190-Gal. tins. 6191-5-gol, tins.

There Is Always a Complete

Display of Evergreen Shrubs

at Each of Our Salesyards

Bright scarlet flowers of the CarnationFlowered Dwarf Pomegranate

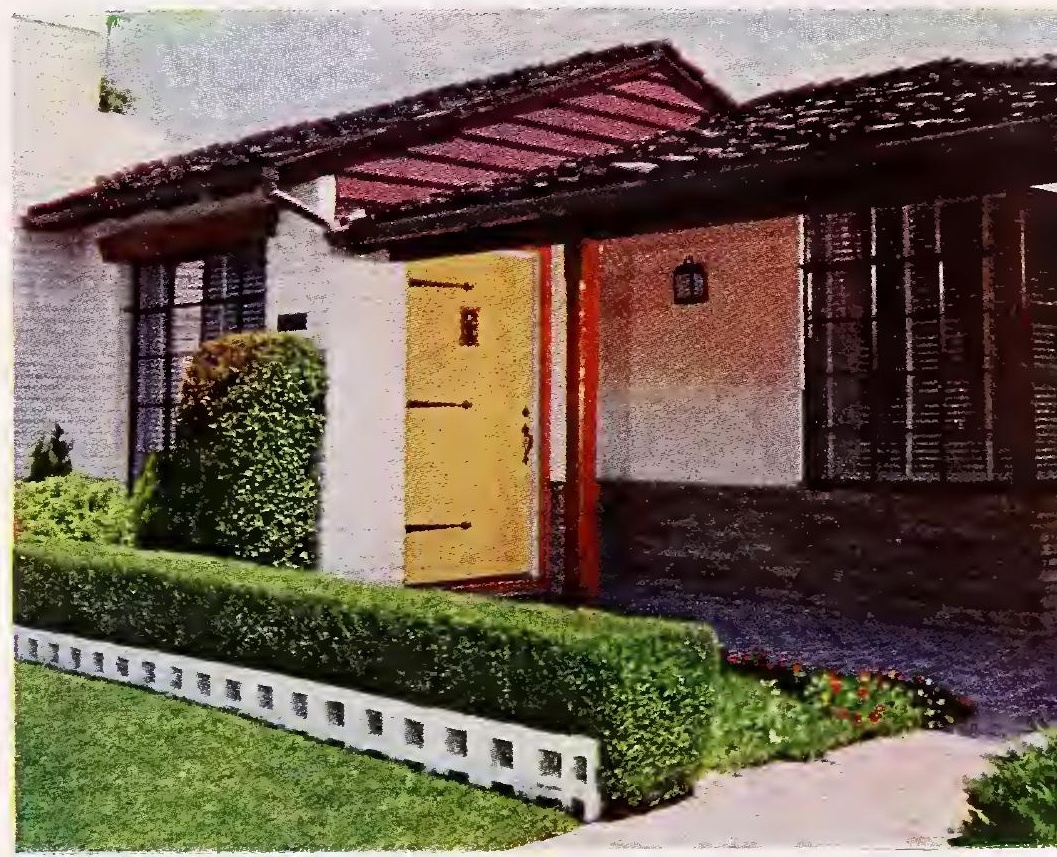

Compact Myrtle is ideal for low hedges

\section{Osmanthus fragrans Sweet Olive}

Large, handsome, dark green foliage and small, white, extremely fragrant flowers in clusters, the cloying sweetness of these flowers, like gardenia and hyacinth mixed, will betray their presence in the garden before you see the plants. Plant it to the windward and the breeze will waft the perfume over the entire garden. A splendid large background shrub. Plant in the sun near the coast-part shade inland. $10 \mathrm{ft} .15^{\circ}$ 6225-Gol. tins, $\$ 1.50$. $6226-5$-gol. tins, $\$ 4.75$.

Photinia serrulata Nova Compact Cbinese Photinia For California and Arizona there is no finer large evergreen shrub. It is always clothed with great, dark, shining, 8-inch leaves, which are dotted during fall and winter with occasional brilliant red leaves. In spring the plant becomes a solid mass of great 6 -inch heads of white flowers. It grows anywhere with ease. 8 to $10 \mathrm{ft}$. $5^{\circ}$ $6330-$ Gol. tins, $\$ 1.50$. 6331-5-gal. tins, $\$ 4.75$.

\section{Use Stock Numbers}

When ordering by mail, please indicate the stock number prefacing each item in addition to the item name on your order blank. It will help us to fill your order promptly and correctly. 


\section{Armstrong}

Pyrus kawakami Eiergreen Pear

One of the best looking and most useful plants for California, since it may be grown as a large shrub, a small tree, or effectively espaliered against a wall or fence. The fresh, luxuriant pear foliage is handsome and evergreen the year around. In the spring the foliage is almost obscured by masses of fragrant white flowers, making the plant one of the most beautiful sights imaginable. 8 to $12 \mathrm{ft} .15^{\circ}$ $6430-$ Gal. tins, $\$ 1.50$. $6431-5$-gal. tins, $\$ 4.75$ 6432-5-gal. tins, Espalier, $\$ 8.50$.

\section{Raphiolepis delacouri Delacour Hautborn}

One of the loveliest of pink-flowering evergreen shrubs for California gardens. This plant makes a bushy, rounded, compact mound of rich olive-green foliage, the new growth being mahogany-red. In the spring it is covered with big 4-inch panicles of clear rosy pink flowers, deeper in color than those of the Pink Indian Hawthorn. Sun or part shade. 5 to $8 \mathrm{ft} .15^{\circ}$. $\quad 6440-$ Gal. tins, $\$ 2.25$. $6441-5$-gal. tins, $\$ 6.50$

\section{Raphiolepis indica rosea Pink Indian Hawtborn}

One of the finest flowering shrubs for California, it is covered in early summer with the most magnificent large 6-inch panicles of half-inch pink flowers resembling apple blossoms, sweetly fragrant. The foliage is extremely handsome and the flowers are followed by interesting clusters of blue-black berries. Ours are cutting-grown plants and ordinary seedlings will never even approach them in beauty. See illustration on page 55.3 to $5 \mathrm{ft} .15^{\circ}$. 6445-Gal. tins, $\$ 2.25$. 6446-5-gal. tins, $\$ 6.50$.

\section{Rhamnus crassifolia Tbick-Leaf Coffee Berry}

A native Californian, medium in size, rounded and densely clothed right down to the ground with dark green, 3 -inch leaves. Use it anywhere that you want a goodlooking permanent background shrub, grows with little care, almost no water, and is always attractive. The coffee-like berries are first red, then black. 5 to $6 \mathrm{ft} .15^{\circ}$.

Exotic, long-lasting flower of the Strelitzia

6455-Gal. tins, $\$ 1.75$

\section{Rondeletia cordata}

It makes a magnificent clump of glossy bright green foliage throughout the year. Covered in spring with big heads of richly colored blooms as shown in color illustration on page 55 . The buds and flower tubes are deep reddish salmon, while the petals are flesh-pink with a yellow-bearded throat. The plants we have are so beautiful and so full of flower buds that we get a lot of pleasure sending them to you, and you'll get far more pleasure from them for many years to come. 4 to $6 \mathrm{ft}$. $26^{\circ}$. $6780-$ Gal. tins, $\$ 1.50$. $6781-5$-gal. tins, $\$ 4.75$.

\section{Rondeletia amoena}

Another lovely foliaged, brilliantly flowered beauty with even more vivid flowers than the above kind. The flowers are rich pink with yellow-bearded throat. Both of these Rondeletias grow luxuriantly anywhere in the coastal and foothill regions of Southern California. 4 to $6 \mathrm{ft}$. $26^{\circ}$. 6775-Gal. tins, $\$ 1.50$. 6776-5-gal. tins, $\$ 4.75$.

\section{Romneya White Cloud Improted Matilija Poppy}

The California Matilija Poppy has long been one of the most popular of native plants. This new hybrid is a great improvement over the ordinary Romneya, larger and more beautiful both in flower and foliage. Snowy white 8-inch blooms, graceful in spite of their size, are held on the ends of 5 to 6 -foot stems. The plant makes a widespreading, many-stemmed clump, clothed right down to the ground with big blue-gray 5-inch leaves. May freeze down in colder areas but will come right up again in the spring. Full sun. $6 \mathrm{ft} .15$ $6470-$ Gal. tins, $\$ 2.00$. $6471-5$-gal. tins, $\$ 6.00$

Extremely fragrant flowers of Viburnum burkwoodi

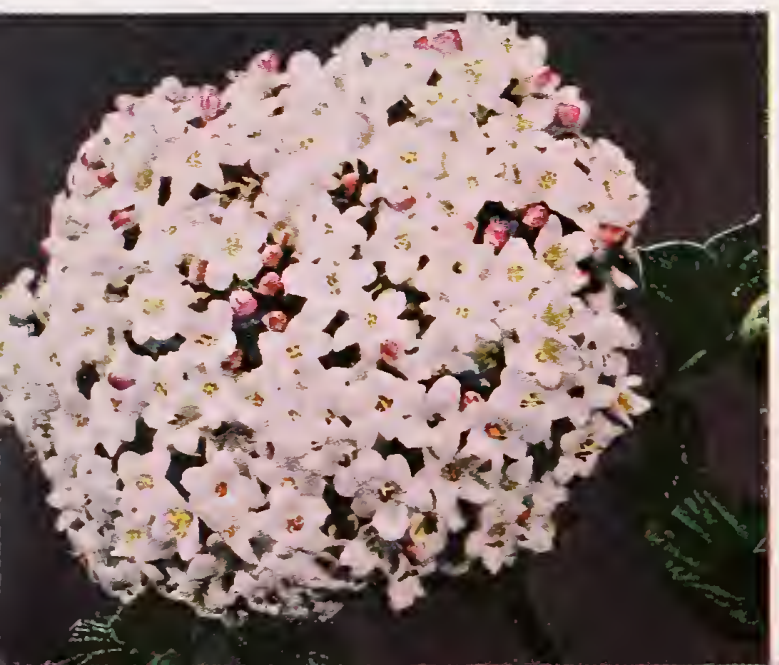

\section{Rosemary}

Rosmarinus officinalis A delightful little plant with its fragrant gray-green foliage and little light lavender blooms. Leaves are used for seasoning. $3 \mathrm{ft.} 5^{\circ}$ $6480-$ Gal. tins, $\$ 1.25$ Rosmarinus officinalis Prostrate The same fragrance, blooms, and foliage as above but is a creeping form of Rosemary which becomes 2 or 3 feet across but never gets over 8 inches high. $5^{\circ}$

$6485-G$ al. tins, $\$ 1.50$

\section{Salvias}

Salvia leucantha A 2 -foot shrub with many spikes of woolly violetpurple and white flowers in late summer and fall. Full sun. Cur back in winter $15^{\circ}$ 6490-Gal. tins, $\$ 1.25$

Salvia mexicana Tall and fast-growing with rich deep blue flower spikes in late winter. Prune back after blooming. Full sun. $28^{\circ}$.

6495-Gal, tins, \$1.25.

\section{Sollya heterophylla Australian Bluebell Creeper}

Another native of Australia which does very well in our California climate. A small, trailing shrub with many slender twining stems, growing from 2 to 6 feet long. It is hardy in most a reas, and a great favorite because of its brilliant blue, bell-shaped flowers. Especially valuable for covering banks, rock work, and low fences. Makes an attractive border plant when pruned. $22^{\circ}$.

$6550-$ Gal. tins, $\$ 1.25$

\section{Spartium junceum Big Yellow Spanish Broom}

Fast-growing with many slender, bright green branchlets almost devoid of leaves. Bears almost continually large pea-like, bright yellow flowers. Very fragrant. Thrives in the salt spray of the seashore or the hot sun of the desert. $10 \mathrm{ft} .10^{\circ}$

\section{Sphaeralcea umbellata Mexican Mallow}

Fast growing with big, luxuriant leaves and bright crimson cup-shaped flowers two inches across, with a white splash at the base of the petals. Blooms all through the late winter, spring and summer and in September is still going. The hotter the weather, the better it likes it. You can leave it for six weeks without water, it doesn't mind it a bit. 4 to $6 \mathrm{ft}$. $19^{\circ}$. 6560-Gal. tins, $\$ 1.50$. 6561-5-gal. tins, $\$ 4.75$.

\section{What to Plant? \\ Where to Plant?}

If you are planting your new home or bringing your present planting up to date let us help you. You will find a well informed courteous staff at each of our 5 salesyards glad to assist you with your problems. If you'd like to leave it all to us, you can take advantage of our complete landscape service and be sure of having a garden of which you can be proud whether your place be large or small. See details on page 31 . 


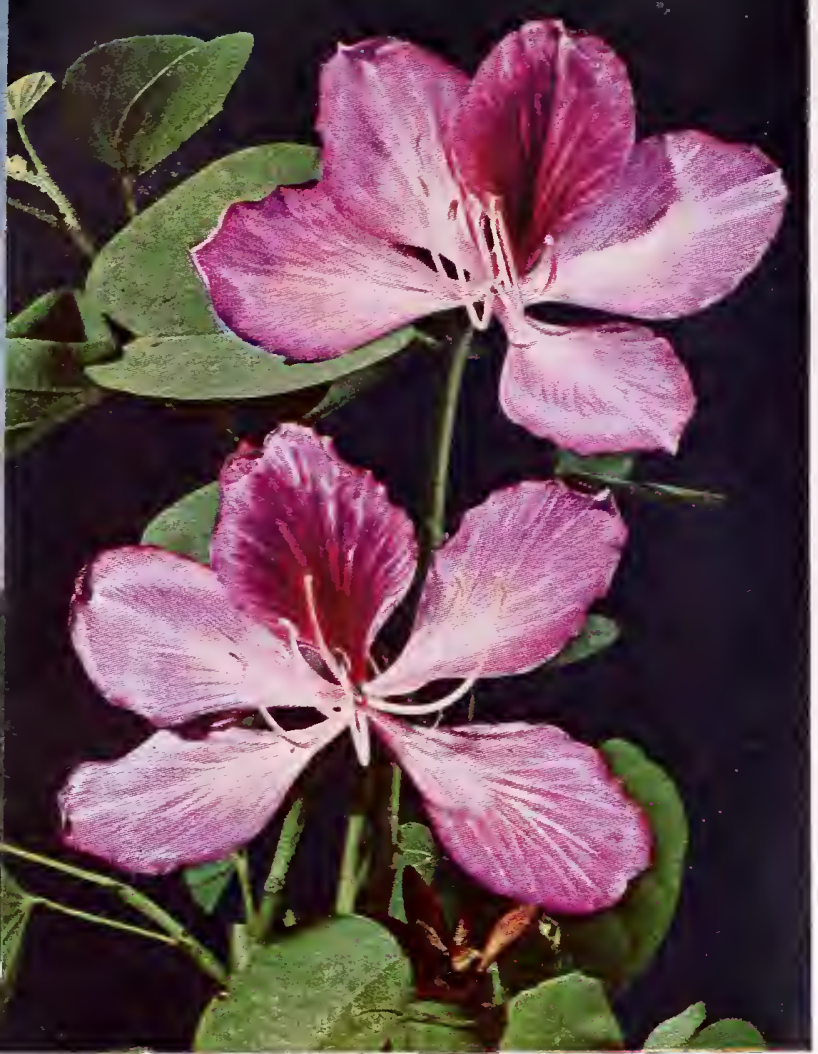

Beautiful multicolored flowers of the Orchid Tree

\section{Acacia baileyana Silver Wattle}

Probably the most handsome of all acacias, with beautiful fernlike, silvery blue-green foliage. It is completely enveloped from January to March by great sprays of lovely fragrant lemon-yellow flowers. Large, spreading, and fast growing, it makes a beautiful garden tree. $30 \mathrm{ft} .10^{\circ}$

$4811-5$-gal. tins, $\$ 4.25$

\section{Acacia longifolia Ev'erblooming Acacia}

A fast growing upright tree, making a dense round head. It has long narrow leaves with small creamy-yellow flowers during the summer. This variety does not flower quite as heavily as some of the acacias, but if you want a neat, compact, good-looking tree in a very shor time, and one that does not take very much care, this is the one you are looking for. $25 \mathrm{ft} .18^{\circ}$. 4816-5-gal. tins, \$4.25.

\section{Acacia podalyriaefolia Pearl Acacia}

This dwarf spreading acacia has unusual pearl-grey foliage and the showiest and most spectacular flowers of all acacias. Blooms from November to February and the big canary-yellow flower balls are at their best right at Christmas time. Excellent for cutting. Plant in ful sun. 15 fr. $18^{\circ}$. 4820-Gal. tins, $\$ 2.00$. 4821-5-gal. tins, $\$ 6.00$
Nothing improves the California landscape more than evergreen trees. We need all of the green foliage that we can get and we need summer shade. You'll find many magnificent trees here which are rarely seen in California because planters simply do not know how attractive they are. Such trees include the Pearl Acacia, Orchid Tree, Cape Chestnut, Shamel Ash, Sweetshade, White Lily Tree, and Dwarf Magnolia.

Shipping Weight: The average shipping weight of plants in gallon tins is for complete shipping information.

Quantity Discount: There are special discounts on 10 or more trees of ne variety or 25 assorted trees or plants. See page 31 for complete details.

Planting Time: The black squares under each month in the calendar indicate

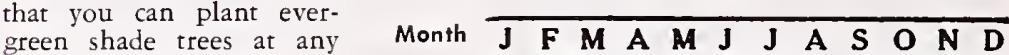
ime during the entire year. From Tins

\section{Shade and Fruit, Too}

Tany trees ate not only very ornamental and have beautiful evergreen foliage, but they will give you plenty of fruit, too. Two or three avocados will furnish fruit almost the year round. Olives make fine shade trees, are picturesque, and create a typically California atmosphere. There are several good shade trees listed among the subtropicals, pages 97 to 99 - such things as cherimoyas, sapotes, and the unusual Macadamia, or Queensland Nut.

\section{Bauhinia variegata Orcbid Tree}

An exceedingly showy small tree with interesting large, velvety, twolobed leaves. Partially loses its leaves in April to better display its quantities of magnificent large flowers of deep pinkish lavender, with brilliant markings of purple and yellow, 3 inches across. It grows easily except directly on the coast, stands a lot of heat and considerable cold. If you would like a whole tree of orchids in your garden, plant one of these beautiful Bauhinias. It takes little more room than a large sized shrub and will fit into almost any sunny corner. $15 \mathrm{ft} .20^{\circ}$ $4886-5$-gal. tins, $\$ 4.75$. 6900 -Balled, 6 to $8 \mathrm{ft}$., $\$ 15.00$ $6901-B$ alled, 8 to $10 \mathrm{ft}$., $\$ 20.00$

Both of the larger sized balled trees are available in a white flowering strain at no increase in price.

\section{Brachychiton acerifolius Flame Tree}

This unique tree with its large, shining, maple-like leaves, is covered in the early summer with many cup-shaped blooms of rich red on scarlet stems. In the southern coastal counties it is one of the showiest flowering trees that can be planted. When it is a solid mass of dazzling color it makes a wonderful sight against the blue of the sky or mountains in June. 30 to $50 \mathrm{ft} .24^{\circ}$. $6691-5$-gal. tins, $\$ 5.25$.

\section{Brachychiton populneus Bottle Tree}

Excellent for narrow parkways and dry soils because of its small narrow pyramidal shape and deep-rooted habit. The pretty little, bellshaped, cream-colored flowers add to its attractiveness. Excellent for the desert or anywhere else.

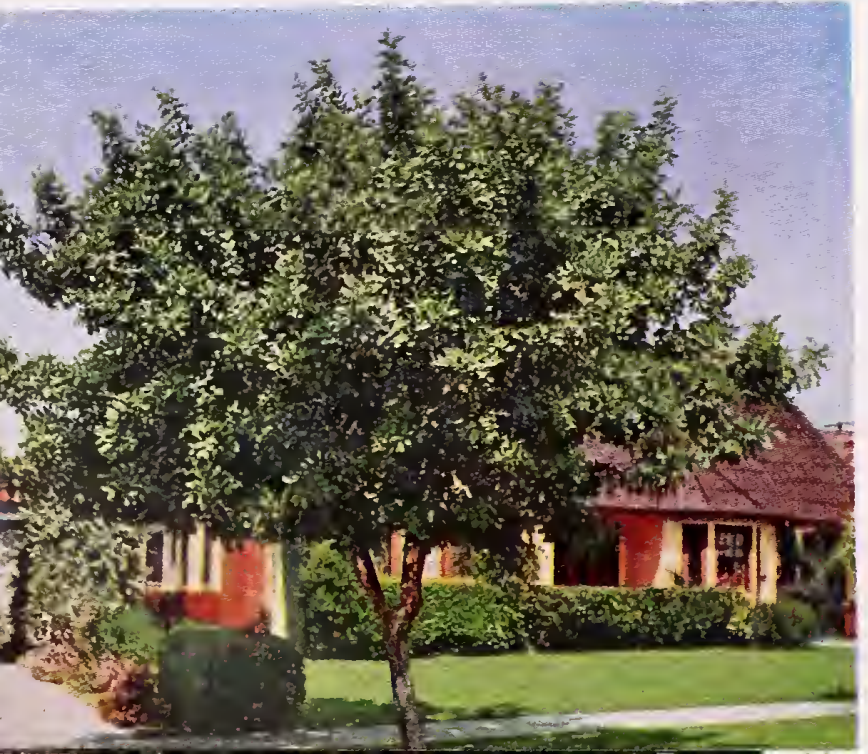

\section{Calodendrum capense}

Cape Chestmut

The medium sized, compact, rounded head of glossy green foliage is covered solidly with great 6 to 12 -inch panicles of unbelievably beautiful rosy lavender blooms in early summer. Likes full sun, a light soil, and little water. Protect it for the first two years where temperatures go below $22^{\circ}$. 25 to $40 \mathrm{ft} .15^{\circ}$. $4981-5$-gal. tins, $\$ 5.25$.

\section{Cinnamomum camphora}

Camplor Tree

The Camphor Tree often attains great size, but not for many years. Because of its moderate growth and cegular form, it is often used as a parkway or garden tree. Always handsome with its dense, bright green, glossy foliage tinted with rich bronze in the spring. It is a clean, hardy, deep-rooted tree sure to give satisfactory results nearly anywhere. $75 \mathrm{ft} .10^{\circ}$

5156-5-gal. tins, $\$ 4.75$. 5157-16-inch box, $\$ 20.00$
Lovely flowers of Calodendrum capense

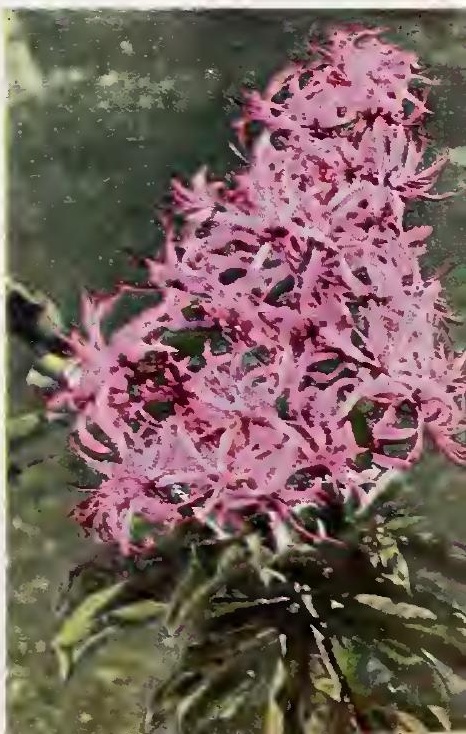




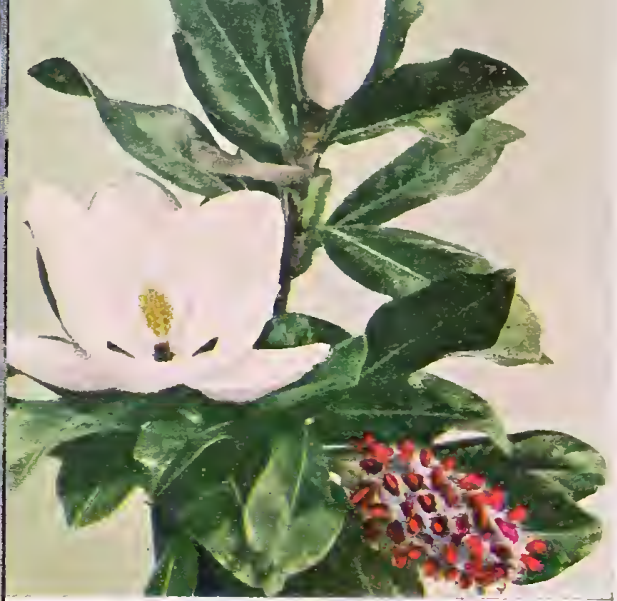

Southern Magnotia
Ficus retusa Indian Laurel

Always neat appearing with a compact rounded head of thick leathery leaves. Fine for small parkways, patio corners and other locations where a trim little tree is wanted or there is little room for roots. Can be trimmed readily and kept any desired height. The more it is trimmed the better it looks. Grows readily coast or inland. $20 \mathrm{ft} .25^{\circ}$.

$$
6736-5 \text {-gal. tins, } \$ 5.25 \text {. }
$$

$6737-T u b s, \$ 10.00$

\section{Fraxinus uhdei Shamel Asb}

Mr. A. D. Shamel of the U. S. Department of Agriculture was in Mexico several years ago and admired this splendid Evergreen Ash so much that he brought back seeds for propagation in California. It is now a familiar sight in many Southern California gardens. We like the beauty of the long, glossy, pointed leaves, its convenient medium size, tall slender shape, and its clean, cool, trim appearance. The tree grows quite rapidly and you will not have to wait long for shade. It always maintains a slender upright growth, making it a splendid parkway tree. 25 to $30 \mathrm{ft} .15^{\circ}$.
The Camphor is an ideal parkway tree

\section{Grevillea robusta Silk Oak}

A tall, slender tree, with fern-like leaves, covered in the early summer with comblike yellow flowers 6 inches long. Drought and heat resistant. Ontario's famous Euclid Avenue has the outer parkway of its double drive planted over much of its length with these Grevilleas. California Pepper trees line the center parkway. $75 \mathrm{ft} .15^{\circ}$

5686-5-gal. tins, $\$ 4.25$

\section{Hymenosporum flavum Su'eetshade}

This slender, small tree has handsome evergreen foliage all the year, and in spring and early summer produces masses of long, tubular, creamy yellow blossoms. The flowers are many times the size and have many times the fragrance of orange blossoms-believe it or not. Hymenosporum makes a fine small parkway tree or can be used against a wall or building to make a tracery effect where dense shade is not desired. Grows anywhere except in desert sections. $25 \mathrm{ft} .20^{\circ}$. $5841-5$-gal. tins, $\$ 6.00$

\section{Jacaranda acutifolia}

One of the handsomest of flowering trees. It forms a round, symmetrical head of light green, fernlike foliage which in June becomes a mass of light violetblue tubular flowers. These trees in full bloom are one of the Southern California sights which amazes the Eastern visitor. Does not make a dense shade, but fits well into landscape effects because of its picturesque habit of growth and the showy flowers just like you see in the illustration below. $30 \mathrm{ft} .22^{\circ}$.

5891-5-gal. tins, $\$ 4.75$. $\quad 6966-$ Balled, 8 to 10 ft., $\$ 20.00$

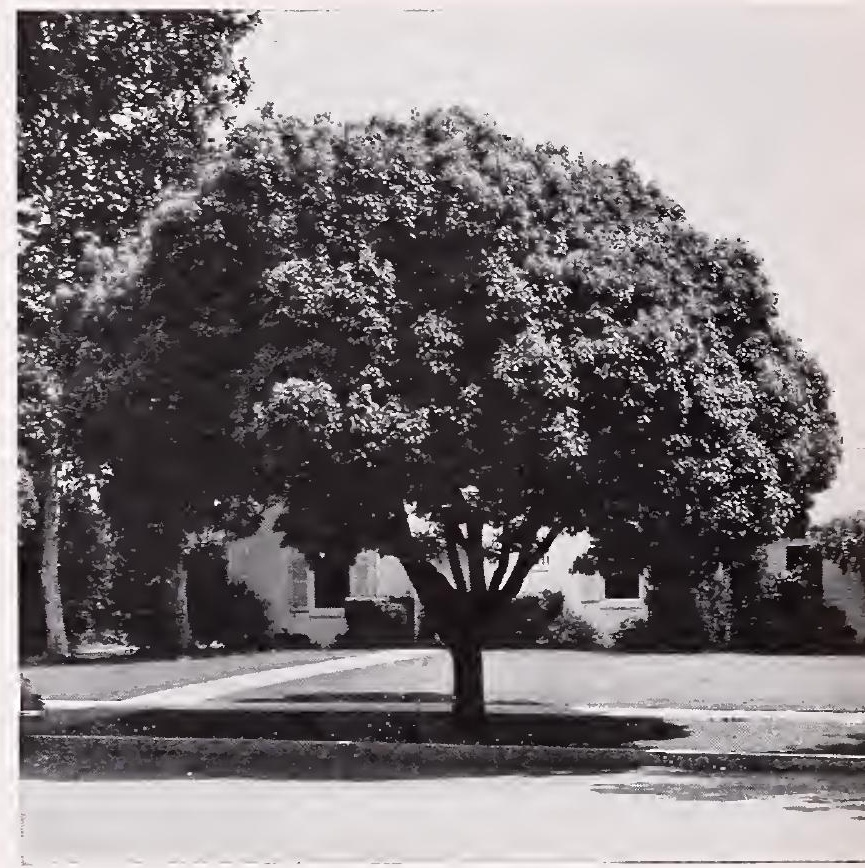

\section{Magnolia grandiflora Soutbern Magnolia}

One of the grandest of our American evergreen trees, with beautiful, dark green, heavy, shiny foliage. In the summer and fall it produces spectacular, large, pearly-white flowers, 6 to 8 inches across, intensely fragrant. Eventually it gets to 60 feet, so give it plenty of room. A tree that brings memories of the old Southern gardens into our California landscapes. Should have a considerable amount of water when young. $60 \mathrm{ft} .5^{\circ}$

$6061-5$-gal. tins, $\$ 5.25$.

7016-Balled, 4 ta 5 ft., $\$ 12.50$. 7017-Balled, 5 ta $6 \mathrm{ft}$., $\$ 15.00$.

7018-Balled, 6 ta $8 \mathrm{ft}$., $\$ 17.50$.

The Jacaranda with its lacy foliage and clouds of lavender-blue flowers in summer is one of the most admired trees in California

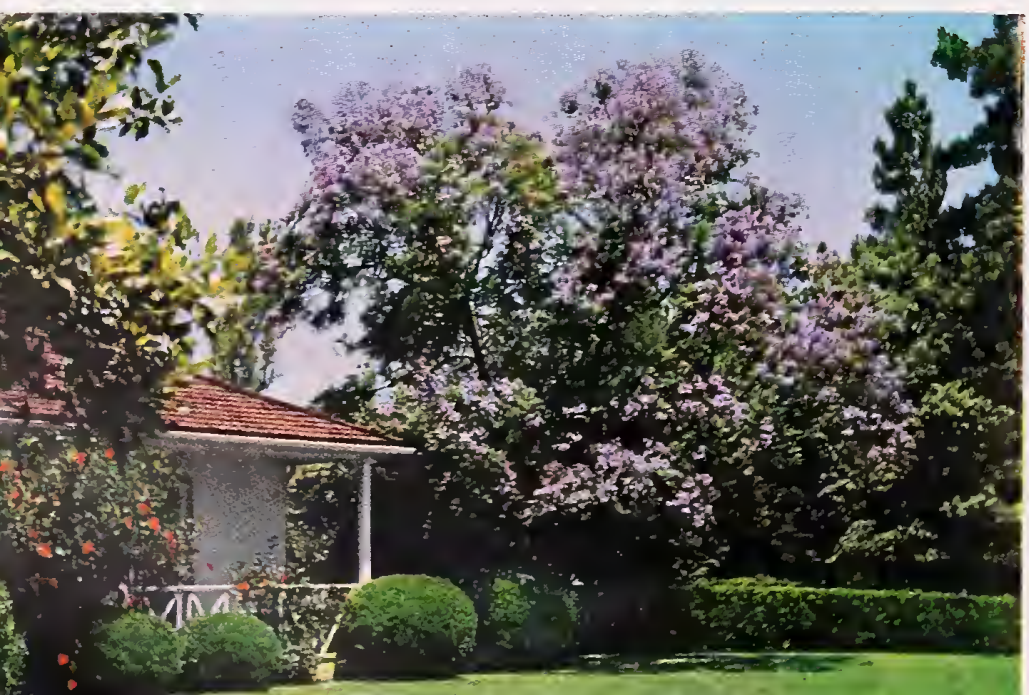

\section{Magnolia grandiflora exoniensis}

Duarf Soutbern Magnolia

In this dwarf variety of the Southern Magnolia you can get all the beauty of foliage and flower of that popular and beautiful tree but have it in a small, compact form that will not get too big for the average small home place. It has the same big polished leaves, the same big, pearly-white, fragrant blooms and attractive red seed cones, but grows quite slowly, stays comparatively small, and blooms while very young. The Dwarf Magnolias grown by us are specially grafted plants which insures their being the true dwarf variety. We think it is one of the most beautiful and useful of small evergreen trees. 15 to $20 \mathrm{ft} 5^{\circ}$. 7021-Balled, 4 ta 5 ft., $\$ 15.00$.

7022-Balled, 5 to 6 ft., $\$ 17.50$

\section{Parkinsonia aculeata Jerusalemthom}

This beautiful native of the Colorado desert thrives in dry soil almost anywhere in the Southwest. For this reason, it is one of the most popular shade trees for desert planting. During the early summer it becomes a mass of small bright yellow flowers, affording a striking contrast to the smooth bright green bark of the trunk and leaflets. Makes a modest little tree, not too large. If you have a hot, dry, sunny spot where a restful bit of shade is needed and some lovely color in the spring, this will give it to you. $25 \mathrm{ft} .18^{\circ}$. $6236-5$-gal. tins, $\$ 4.75$.

\section{Quercus agrifolia California Live Oak}

A picturesque and beautiful native tree is this handsome California Live Oak. Its dark, glossy green, medium-sized leaves form a dense handsome head and it does well almost everywhere except in the extreme desert sections. It grows rapidly and we can enthusiastically recommend it for planting in parkways or any other location where a good-sized, long-lived, evergreen shade tree is wanted. $50 \mathrm{ft} .10^{\circ}$. $6436-5$-gal. tins, $\$ 5.25$. 


\section{Evergreen Trees}

\section{Schinus molle California Pepper}

This unique and beautiful tree has become so identified with California that it now stands as almost a symbol of the Golden State. Grows anywhere with little care. Its graceful lacy foliage and bright red berries stay on through the winter and these with the gnarled rugged trunk make it a picturesque tree. Because it thrives so easily and shades a great space of ground under conditions not suited to many more pampered trees, it will always be valuable for California, $50 \mathrm{ft} .10^{\circ}$. 6516-5-gal. tins, $\$ 4.75$. 6517-16-inch box, $\$ 20.00$.

\section{Schinus lentiscifolia Pinkberry Pepper}

Here is an unusual and little known tree that will fit into almost any garden. It has finely cut foliage of a much brighter green than that of the California Pepper and is much smaller in size, never reaching more than 18 feet in height. The branches are rather erect, giving it a handsome compact appearance. We know it is difficult to find small evergreen trees that are resistant to cold, but here is one you won't have to worry about. It will survive the severest California frosts. It makes a cool green little shade tree which requires little care. $18 \mathrm{ft} .15^{\circ}$ $6511-5$-gal, tins, $\$ 6.00$

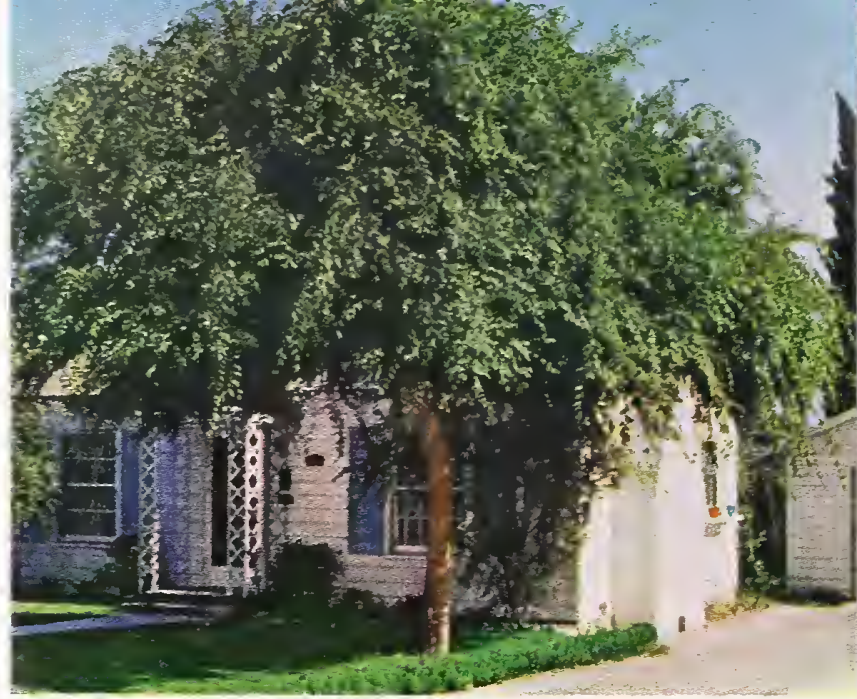

The handsome small Evergreen Elm

\section{Schinus terebinthifolia Brazil Pepper}

A much smaller tree than the California Pepper, having larger, broader leaves and greater quantities of scarlet berries. It makes a neat, symmetrical, round-headed tree. Does equally well under the hottest desert conditions or on the coast. For the small home place it is much more satisfactory than the California Pepper because it does not get so large, and is a cleaner, less brittle tree. 15 to $20 \mathrm{ft} .22^{\circ}$. $6521-5$-gal. tins, $\$ 4.75$. 6522-16-inch box, $\$ 20.00$.

\section{For Planting in Lawns}

Certain of the evergreen trees are particularly good for planting in lawns because of their size, and because they like the added moisture. Among these are the Evergreen Elm, the Bauhinia, the Clethra, Ficus retusa, Quercus agrifolia, and Crinodendron.

\section{Ulmus parvifolia Evergreen Evergreen Elm}

A small tree with a spreading crown of slender drooping branches and bright green Ieaves. For a small home shade tree, we highly recommend it. Next to the Carob, the Evergreen Elm is probably the most popular evergreen tree planted in Southern California at the present time. In very cold sections it may drop its leaves for a short time in winter. Many inferior seedlings of Ulmus parvifolia are often sold as Evergreen Elms. The Armstrong type is carefully selected for its evergreen habit, beautiful foliage and handsome shape, and they are grown from cuttings to insure that every tree is the same. We could go on extolling the praises of this tree for a whole page, but it is sufficient to say that we think this is the most satisfactory small shade tree that can be grown anywhere in Southern California. $25 \mathrm{ft}$ $10^{\circ}$. $6626-5 \cdot \mathrm{gal}$ tins, $\$ 4.75$ 6627-16-inch box, $\$ 20.00$. 7111-Balled, 8 to $10 \mathrm{ft}$., $\$ 20.00$

\section{Palms and Bamboos}

The trees contributing most to California's romantic atmosphere of the tropics are the stately palms. The mature specimens with their graceful evergreen fronds have a restful dignity which is common to them alone.

\section{Arecastrum romanzoffianum Queen Palm}

Southern California's favorite palm, often called Cocos plumosa. It has a tall, slender, smooth trunk, topped with a plumelike crown of feathery graceful fronds. Once established it needs very little water, and for parkways, patios, and lawn planting, the Queen Palm lends an informal, tropical appearance. 18 to $20 \mathrm{ft} .17$

6890 -Balled, 4 to $5 \mathrm{ft}$., $\$ 8.50$. $\quad 6891-$ Balled, 5 to $6 \mathrm{ft} ., \$ 10.00$

\section{Phoenix canariensis Ornamental Date Palm}

A familiar sight on many parkways throughout Southern California, with its immense crown of beautiful curving fronds, 15 feet long, dark green in color. Grows very rapidly. $10^{\circ}$. $6321-5$-gal, tins, $\$ 4.75$.

\section{Washingtonia robusta Mexican Fan Palm}

A very picturesque palm is this tall, stately tree with a slender trunk topped by a head of dark green, fan-like fronds. Native of the California and Mexican desert. It will grow 50 to 100 feet in height. $12^{\circ}$. $6651-5$-gal. tins, $\$ 5.50$

\section{Sinocalamnus oldhami (Dendocalamus latiflorus)}

Giant Bamboo

Quickly makes an enormous clump of huge canes when once established. 40 to $60 \mathrm{ft} .20^{\circ}$. $6546-5$-gal. tins, $\$ 4.75$.

\section{Phyllostachys aurea Fish Pole Bamboo}

Grows rapidly into a dense compact clump of gracefully foliaged canes, 15 to 20 feet in height. 6336-5-gal. tins, $\$ 4.75$.

\section{Cortaderia selloana Pampas Grass}

Handsome big clump of long, arching, grass-like leaves, surmounted by great silvery white plumes. $6 \mathrm{ft}$.
No tree is more typical of Southern California than the graceful Queen Palm

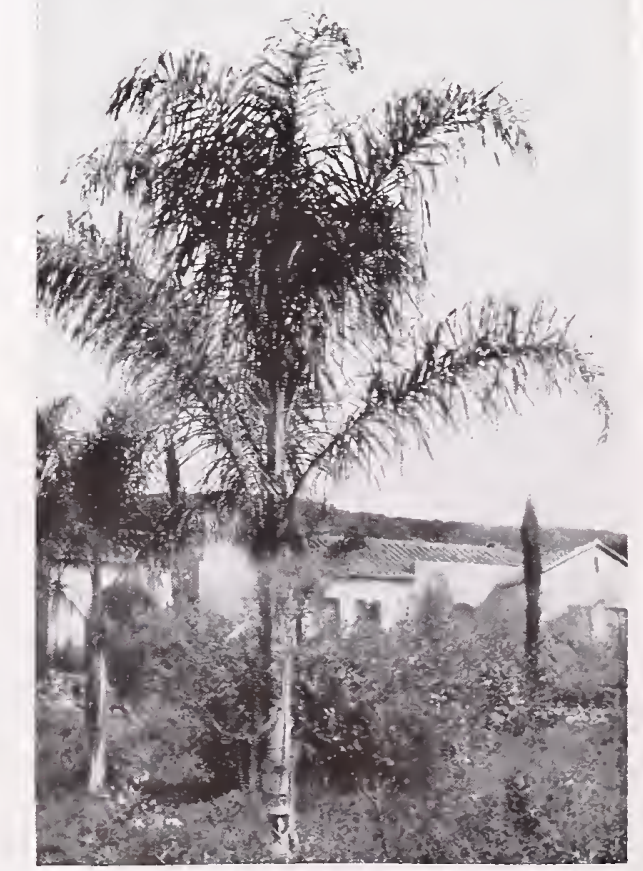




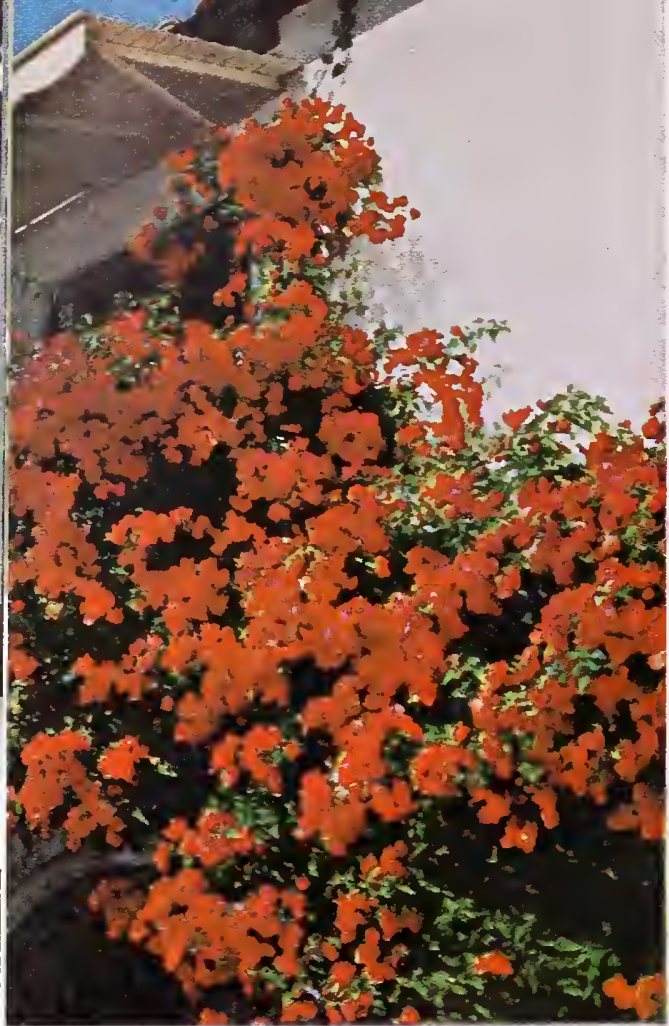

Bougainvilleas are a spectacular mass of color throughout the entire year

\section{Campsis tagliabuana Mme. Galen}

Orange-Red Trumpet Vine

A fast growing vine with great clusters of large brilliant scarlet-orange trumpet flowers. It will cover an arbor or trellis with a profusion of brilliant color in the spring and summer. Perfectly hardy anywhere, leafless in winter. See illustration on page 61 . Bare root during January, February and March. Zero.

$$
\text { 6821-5-gal. tins, \$2.75. 2660-Bare root, \$4.25. }
$$

\section{Cissus capensis Evergreen Grape}

One of the most luxuriant, picturesque and daintily foliaged of all vines for rambling over a large space is this wild grape vine. The allyear foliage is enhanced in the summer with quantities of reddish black edible grapes which make delicious jelly. Sun or part shade. $28^{\circ}$. 5160-Gal, tins, \$1.50. 5161-5-gal. tins, $\$ 4.75$.

\section{Cissus hypoglauca Glossy-Leaved Creeper}

An informal rambling creeper or climber which will spread over any kind of object in a short time. Particularly valuable in providing a mass foliage effect. We like it because the handsome shiny evergreen five-fingered leaves look as though they had been polished. They are just as beautiful in the middle of winter as they are during the spring, summer, and fall. $24^{\circ}$

5165-Gal. tins, \$1.50. 5166-5-gal. tins, $\$ 4.75$.

\section{Armstrong}

Many exotic, beautifully flowered vines of the tropics are listed here in addition vines of colder climates which thrive in California. You can selec planted in the shelter of a building or another Except for a few specified kinds, all vines listed here can be shipped and planted at any time during the year. Gal. tins weigh approximately $10 \mathrm{lbs}$; 5-gal. tins, about 50 lbs. packed. For data on the shipment of plants in

\section{Antigonon leptopus Queen's Wreath}

This magnificent flowering vine from Mexico thrives almost anywhere in Southern Calitop dies clear to the ground, but comes up quickly every spring to make a magnificent $20^{\circ}$

3010-Gal. tins, $\$ 1.75$

\section{Bougainvilleas}

Possibly the most colorful of all semi-tropical flowering vines are the Bougainvilleas. No vine will produce a mass of color for a longer period for they are almost everblooming. Particularly good in coastal areas where the display amazes the tourists.

\section{Bougainvillea Barbara Karst}

Of all the bougainvilleas which make California coastal landscapes so colorful, this has the deepest and richest shade of red. The plant is very vigorous but has smaller foliage and grows more compactly than most other kinds. Blooms immediately. Full sun. $28^{\circ}$ $3035-$ Gal. tins, $\$ 1.50$.

$3036-5$-gal. tins, $\$ 4.75$

\section{Bougainvillea praetorius Bronze Bougainvillea}

This is one of the most unusual bougainvilleas that we grow, with beautiful bronzy gold flowers changing at times to apricot or orangeyellow. Does best near the seacoast. Quite tender. $28^{\circ}$

3050-Gal. tins, $\$ 1.50$. 3051-5-gal. tins, $\$ 4.75$.

\section{Bougainvillea San Diego}

"Tremendous" would be a good word for this variety because everything about it is just that. It will fill your garden with brilliant crimson bracts larger and more spectacular than those of any other bougainvillea. San Diego is one of the most vigorous and fastest growing bougainvilleas we have ever seen. $28^{\circ}$. 3060-Gal. tins, $\$ 1.50$

$3061-5$-gal. tins, $\$ 4.75$

\section{Bougainvillea spectabilis Purple Bougainvillea}

Hardiest of the Bougainvilleas, bearing a mass of brilliant reddish purple flowers. Easily grown, but needs sun. $20^{\circ}$

3030-Gal. tins, $\$ 1.50$. 3031-5-gal. tins, $\$ 4.75$.

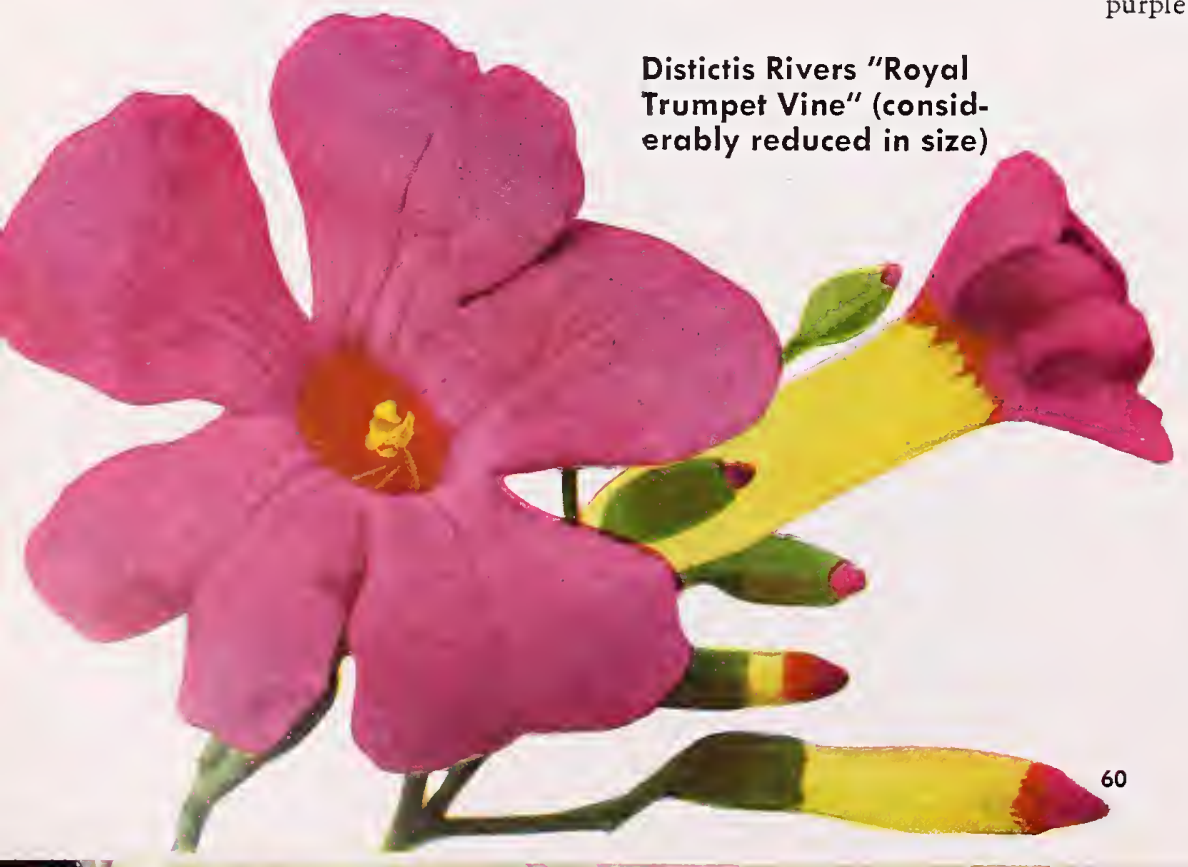

\section{Clematis armandi}

We consider this relatively unknown clematis to be superior to any we have previously grown for California planting. Unlike the clematis of the Eastern States, it makes a fine handsome evergreen ornamental with very big, glossy leaves 8 inches long. Literally covered in the early spring with 2-inch, waxy white, star-like flowers which give off a faint but pleasing fragrance. Strong grower to 20 or 30 feet, prefers at least part shade in warmer inland areas. Hardy down to $20^{\circ}$. 5190-Gal. tins, $\$ 2.50$

\section{Clematis jackmani Purple Clematis}

This is the attractive large flowered Clematis with the showy bright purple flowers, which is so highly prized in the East and Middle West. It does not thrive quite so well here in California, but can be easily grown if desired. The tops should be cut off at the ground during the winter and allowed to start over in the spring. Part shade. $0^{\circ}$. 


\section{Flowering Vines}

\section{Clytostoma callistegioides Violet Trumpet V'ine}

The delicate beauty of its flowers and its luxuriant dark green foliage make it one of California's most beautiful vines. In late winter and early spring it is covered with lovely big trumpet-like flowers of delicate violet. It will clamber over a fence, wall, building, or even over a shrub or tree if you want it to. Sun or shade. $20^{\circ}$ 5215-Gal. tins, \$1.75. 5216-5-gal. tins, \$5.25.

\section{Distictis lactiflora Vanilla-Scented Trumpet Vine}

One of the finest of all vines for the milder regions of California. It makes a dense mass of deep green foliage, covered almost all spring, summer, and fall with big trumper-shaped flowers $31 / 2$ inches across. The flowers open a rich purple, lightening to various lovely shades of lavender as they age. Blooms almost 8 months in the year, the flowers carrying a delightful vanilla scent. $24^{\circ}$.

$$
5400-\text { Gal. tins, } \$ 1.75 \text {. 5401-5-gal. tins, } \$ 5.25 \text {. }
$$

\section{Distictis Rivers Royal Trumpet Vine}

Almost every day of the year the abundant big, glossy leaves are enhanced by cluster of long flaring trumpets, fully 6 inches in length. The tube of the trumpet is brilliant yellow and the open face a gorgeous royal purple, which changes to violet and lila as the flowers age. Always, there is a vivid orange color at the throat. Its brilliancy is breath-taking and it is delightfully fragrant, too. Full sun. 22 $2^{\circ}$. Plant Pat. No, 554 $5405-$ Gal. tins, $\$ 1.75$. 5406-5-gal. tins, $\$ 5.25$

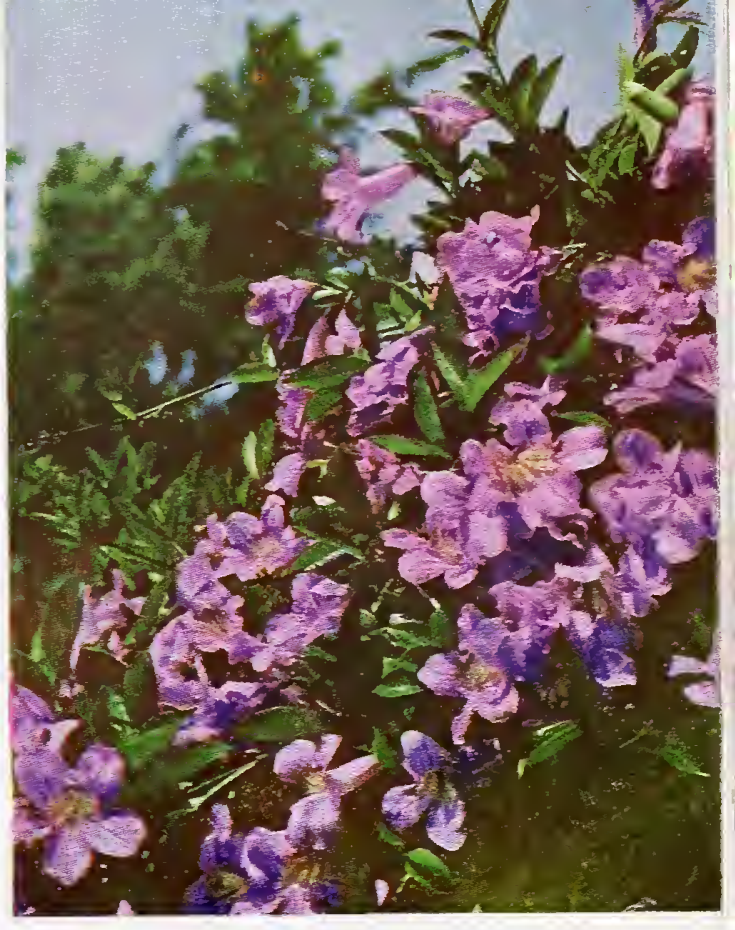

Violet Trumpet Vine (Clytostoma)

\section{Hibbertia volubilis}

Guinea Gold I'ine

Catclaw Yellow Trumpet

Large, brilliant yellow trumpet flowers 3 inches long and 4 inches across. The shoots cling to any surtace making a dense mat of foliage. Excellent for the desert or anywhere else. Full sun. $0^{\circ}$ 5410-Gal. tins, \$1.50. 5411-5-gal. tins, \$4.75.

\section{Ficus pumila Creeping Fig}

The best evergreen vine for covering stone, brick, or wood, making a close mat of small heartshaped dark green leaves which cling closely to any surface. Thrives anywhere in California. Sun or part shade. $15^{\circ}$. 5615-Gal. tins, $\$ 1.25$.

\section{Gelsemium sempervirens}

Carolina Jessamine

A slender twining vine, which is quite hardy and grows rapidly. In the spring it is covered with golden yellow, fragrant, bell-shaped flowers. Excellent for framing a small arch or gateway, or covering a low fence. Grows well in all soils and climates and is always a cheerful mass of color in the spring. $15^{\circ}$.

5665-Gal. tins, $\$ 1.50 . \quad 5666-5$-gal. tins, $\$ 4.75$.
Brilliant flowers of Campsis Mme. Galen

\section{Evergreen Ivies}

Hedera canariensis Algerian I $z^{\prime} y$. We like it better than English Ivy because it grows faster and has bigger and brighter green leaves -6 inches across. 12 5735-Gal. tins, $\$ 1.25$. $5736-5$-gal. tins, $\$ 4.25$. 5737-Flats of $100, \$ 8.00$.

Hedera canariensis Yellowedge Beautiful big leaves handsomely blotched with light green, dark green, and creamy yellow. Shade or semi-shade. 15 $5740-$ Gal. tins, $\$ 1.25$. 5741-5-gal. tins, $\$ 4.25$. 5742-Flats of $100, \$ 8.00$.

Hedera helix English Ivy. Excellent wall or bank covering in sun or shade. A good ground cover. $10^{\circ}$.

\section{Kennedya beckxiana}

A relatively new arrival, this is another of those unusual vines from Western Australia which are so adaptable to our California climate and which add so much color and interest to any garden. The giant sweet-pea-like flowers are very large, bright red in color, with a green splotch at the base Grows to about 10 feet, with very attractive. thick, dark green, glossy foliage. If you live near the coast or in an area where winter temperatures are relatively mild, you'll want this. It is one of the newest and showiest of vines. $24^{\circ}$. 5920-Gal. tins, \$1.75. 5921-5-gal. tins, \$5.25.

\section{Vines and Fruit, Too!}

Many of the grapes listed on pages 88 to 90 are very ornamental as well as being fruitful. Another handsome ornamental vine for warmer sections is the Passion Fruit Vine listed on page 97. 


\section{Thunbergia grandifora}

Sky Flower

In mild locations this is a magnificent vine. It is extremely rapid in growth with the large heartshaped leaves over-lapping to make a dense covering. The color of the flowers is one that is rare in the vines, bright sky-blue, about 3 inches across, they hang in clusters over the plant. If frozen down it will come up and bloom again in the same season. Usually blooms in the fall, winter, or spring when other flowers (and particularly blue ones) are rare. Does best in semi-shade $30^{\circ}$

3630-Gal, tins, \$1.75. 3631-5-gal. tins, $\$ 5.25$.

Sky Flower

(Thunbergia)

\section{Thunbergia gibsoni}

Orange Clock Vine For brilliancy of color, the flowers of this vine are difficult to surpass. Golden orange and from $11 / 2$ to 2 inches across, they never fail to draw attention, and it is a vine which blooms continuously almost every day in the year. You will never have to provide a trellis or anything special for it to cling to, because it will just wander from wherever you plant it, ambling over any stump, rock, fence, or other object, in its path. Best near the coast where temperatures do not drop too low, $30^{\circ}$

3620-Gal. tins, $\$ 1.50$

Stephanotis floribunda Fragrant Corsage Vine

The exquisitely shaped snow-white tubular flowers 1 to 2 inches across, have a delightful fragrance so penetrating that it will fill an entire garden. Waxy and longlasting, the flowers make excellent corsages and you pay handsomely for them at your florist. The vine is exceedingly attractive with its big, thick, 4-inch glossy leaves, which remain dark green and shiny throughout the year. Grow it in your garden or in a large pot on your porch or patio. Plenty of moisture. $30^{\circ}$.

$3610-$ Gal. tins, $\$ 2.00$. 3611-5-gal, tins, $\$ 6.00$.

\section{Trachelospermum jasminoides Star Jasmine}

From the Malay Peninsula comes this splendid vine which will absolutely dominate your garden in the spring and early summer with the marvelous perfume which it wafts on the air from the myriad little star-shaped white flowers. It is worth planting solely for one whiff of the delicate intoxicating fragrance. The vine is strong growing but not rampant, and beautifully foliaged with big, leathery, glossy leaves. It thrives equally well in full sun, shade, or semi-shade, and is hardy almost anywhere in California. May also be grown as a ground cover or as a large shrub if pruned. $18^{\circ}$

\section{Tecomaria capensis Cape Honeysuckle}

Because of its many uses, this is one of the finest all-around plants on our list. It may be grown as a half climber, but it makes an extremely attractive large shrub, as well. The foliage is bright green throughout the year, and in the fall and winter when other flowers are scarce, this is covered with big clusters of bright orange-red tubular flowers. $24^{\circ}$.

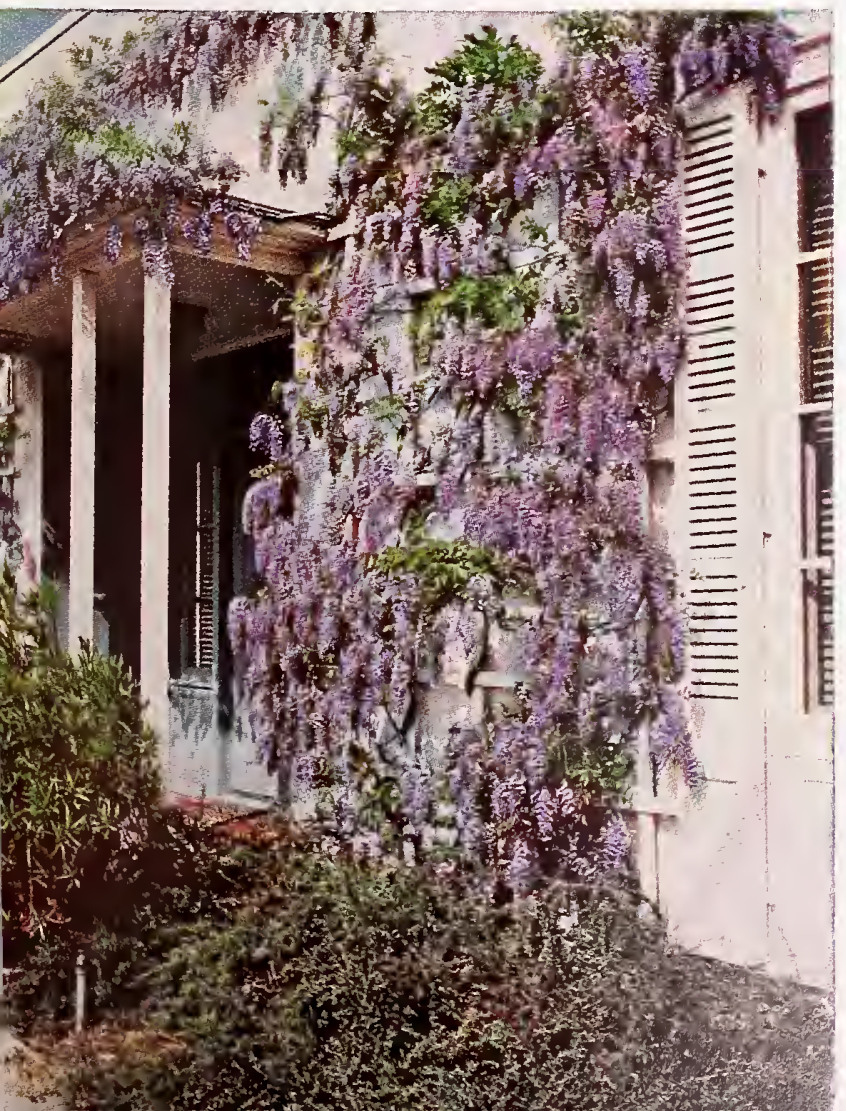

Wistarias are one of the most popular of the spring flowering vines because of the beauty of their long pendulous flower clusters. Give them plenty of room because they grow fast and large. They are leafless in winter. Plant in full sun. Bare-root plants available December to April only.

\section{Wistaria sinensis Chinese Wistaria}

One of the most popular of all Wistarias because it never fails to cover itself with giant, blue flower clusters before the leaves appear in the spring. $5^{\circ}$. 2675-Bare raat, $\$ 3.00$. $\quad 6877-5$-gal. tins, $\$ 5.25$.

\section{Wistaria sinensis alba White Cbinese Wistaria}

This variety is very similar to Wistaria sinensis above, except that the flowers are white and have a honey-sweet fragrance. $5^{\circ}$.

2680-Bare root, $\$ 3.00$. 6879-5-gal. tins, $\$ 5.25$.

Wistaria floribunda macrobotrys Long Cluster Wistaria A very beautiful Wistaria because the lilac flower racemes are often 2 feet long. Blooms later than the Chinese W istaria, and not so heavily. $10^{\circ}$

2665-Bare roat, $\$ 3.00$

\section{Wistaria floribunda macrobotrys Rosea}

Rose Long Cluster Wistaria

Very similar to the Wistaria macrobotrys described above except that the long slender racemes are light lavender-pink in color. $10^{\circ}$

$2670-$ Bare raot, $\$ 3.00$

Wistaria violaceaplena Double Chinese Wistaria

In the springtime, this wistaria will fill your garden with sweet intoxicating In the springtime, $10^{\circ}$. $2685-$ Bare raat, $\$ 3.00$. 6881-5-gal. tins, $\$ 5.25$. 


\section{Fern Pine}

\section{Podocarpus gracilior (elongafus) Fern Pine}

In California gardens this South African forest tree makes a beautiful medium-sized plant, with soft, fine-cut, green foliage, fern-like in appearance. A particularly attractive thing with the tracery of its dark green foliage against a stucco wall. Rather loose and informal in habit, but extremely graceful wherever planted. Sun or half shade. $15 \mathrm{ft} .15^{\circ}$

$$
6376-5 \text {-gal. tins, } \$ 6.50 \text {. }
$$

\section{The California Big Trees}

\section{Sequoia gigantea Giant Sequoia}

Everyone knows about the famous "Big Tree" of the Sierras, oldest and largest of all living things. But do you know how trim and beautiful they are when young, with each sturdy little side branch doing its share to form a perfect cone of blue-green foliage? Grows anywhere in California except desert regions. $5^{\circ}$ below zero.

$$
6525-\text { Gal. tins, } \$ 2.00 \text {. } \quad 6526-5 \text {-gal. tins, } \$ 6.00 \text {. }
$$

7070-Balled, 2 ta $3 \mathrm{ft}, \$ 12.50$. 7071-Balled, 3 ta $4 \mathrm{ft}, \$ 17.50$

7072-Balled, 4 ta $5 \mathrm{ft}$., $\$ 22.50$.

\section{Sequoia sempervirens California Redwood}

The State tree of California is the well known California Redwood. It is among the largest and most picturesque of trees. Growing rapidly into a beautiful specimen, it thrives readily anywhere on the Pacific coast except the desert. $150 \mathrm{ft}$. 5

$$
6530-\text { Gal. tins, \$1.75. 6531-5-gal. tins, \$5.25. }
$$

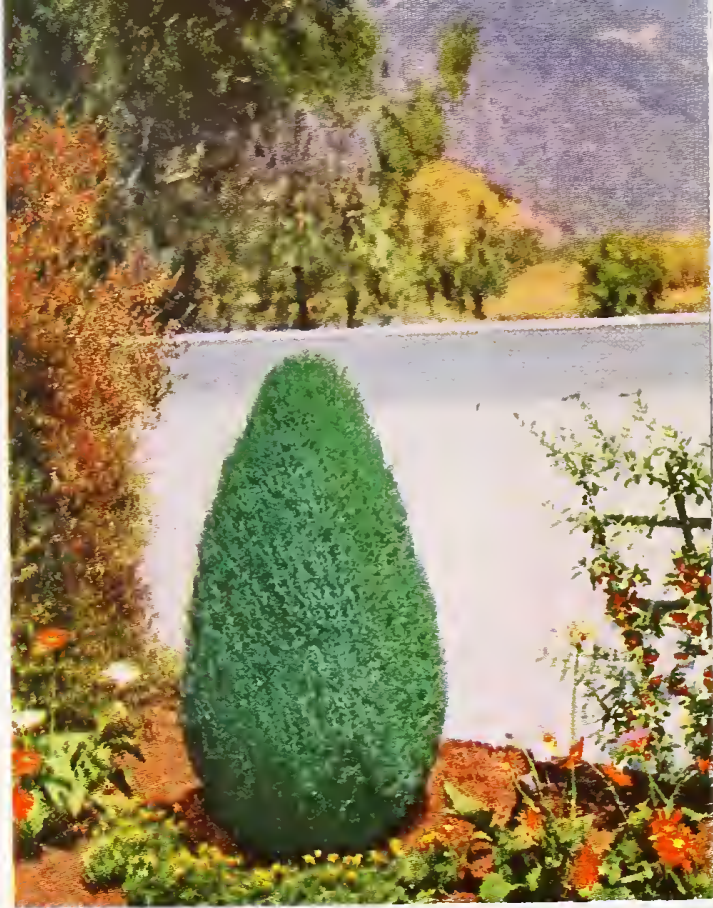

\section{Arborvitaes}

\section{Thuja orientalis Bonita}

This is one of the most perfect of the dwarf, cone-shaped, green Arborvitaes. It never exceeds 5 feet in height and is broad and compact. Fine for formal landscape effect. $5 \mathrm{ft}$. 0

7091-Balled, 18 to 24 in., \$5.50. 7092-Balled, 2 to $2 \frac{1}{1} 2 \mathrm{ft}$., $\$ 7.50$.

\section{Thuja orientalis Berckmann's}

Dwarf Ev'ergolden Arborritae The most popular dwarf conifer for the Southwestern States. Compact and broadly conical in form, with bright golden foliage throughout most of the year. Grows easily anywhere except in the hottest desert sections. Full sun. $6 \mathrm{ft}$. 0

$7080-$ Balled, 1 ta $1 \frac{1 / 2}{\mathrm{ft} .} \$ 4.00$

7081 - Balled $11 / 2$ ta $2 \mathrm{ft}, \$ 5.50$ 7082-Balled, 2 ta $2 \frac{1}{1} / 2$ ft., $\$ 7.50$ $7083-$ Balled, $21 / 2$ to 3 ft., $\$ 9.00$. 7084-Balled, 3 ta $3 \frac{1}{2} \mathbf{f t}$., $\$ 11.00$.

\section{Thuja orientalis Beverly Hills}

Golden Column Aboritae

The tallest and stateliest of the Arborvitaes, growing to a narrow column of golden green foliage, particularly effective for specimen planting or for framing a doorway. Needs full sunshine to bring out the rich golden color. 15 to $20 \mathrm{ft} .0^{\circ}$.
7087 -Balled, 5 ta 6 ft., $\$ 10.00$ 7089 -Balled, 8 to $10 \mathrm{ft}^{\prime}, \$ 17.50$.

\section{Thuja orientalis Pyramidal}

Green Pyramid Arboritae

A tall, narrow column of bright green foliage. Fast growing and thriving anywhere in any climate. 10 to $12 \mathrm{ft} .5$

7097-Balled, 4 ta $5 \mathrm{ft}$., $\$ 8.50$. $\quad 7098-$ Balled, 5 ta $6 \mathrm{ft}$., $\$ 10.00$.

\section{Thuia orientalis Yellow Column}

Golden Pyramid Arborvitae Similar to Beverly Hills but not as tall, with a broader, more bushy base. The spectacular green foliage is tipped with golden bronze. $5^{\circ}$ below zero. 7103-Balled, 5 ta $6 \mathrm{ft}$., $\$ 10.00$. 7104-Balled, 6 to $8 \mathrm{ft}$., $\$ 12.50$.

\section{Irish Yew}

\section{Taxus baccata Irish Irish Yew}

Incomparable for any use where a narrow, upright, perfect green column is desired. It is trim, sedate and formal. It will always be compact and it grows so slowly that the change from year to year is hardly noticed. Has beautiful red berries. Sun or shade, but does not like reflected heat. Plenty of moisture. $5^{\circ}$ below zero.

7077-Balled, 3 to 4 ft., $\$ 25.00$
Picturesque Twisted Juniper

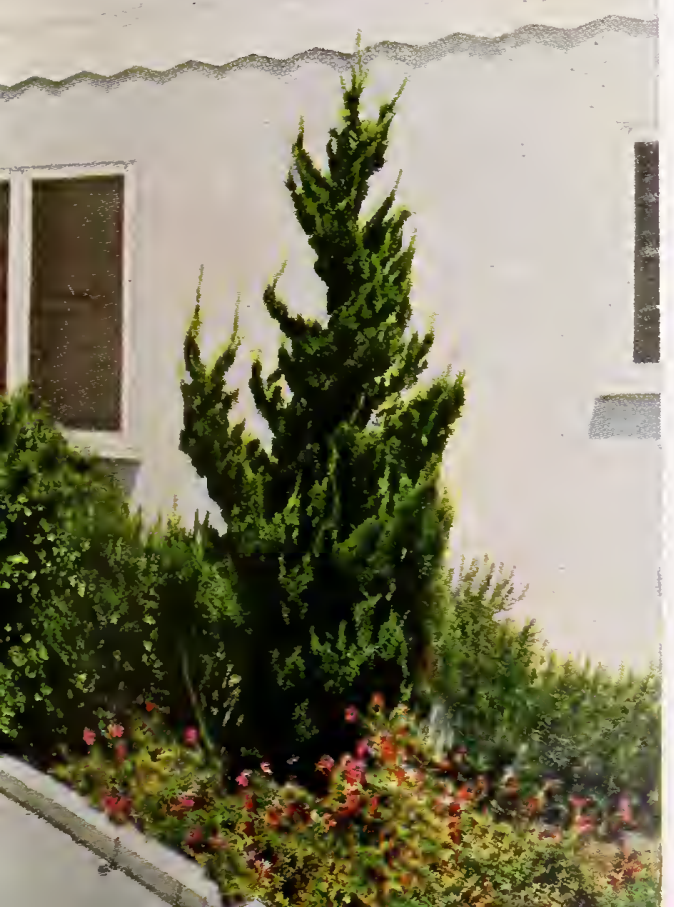

\section{Pines}

\section{Pinus canariensis}

Canary Island Pine

One of the most beautiful permanent pines for California. Extremely long needles in large tufts. The new growth is silver, changing to soft gray-green. Tall and slender. $80 \mathrm{ft}$. $10^{\circ}$ $6341-5$-gal. tins, $\$ 4.25$.

\section{Pinus halepensis Aleppo Pine}

A rapid growing pine suitable for quick effects, particularly in dry locations. Longer-lived than the Monterey Pine but similar in appearance. $50 \mathrm{ft} .5^{\circ}$.

$6346-5$-gal. tins, $\$ 4.25$. 7055-Balled, 3 ta $4 \mathrm{ft}$., $\$ 5.00$. 7056-Balled, 4 to $5 \mathrm{ft}$., $\$ 6.00$ 7057 -Balled, 5 to $6 \mathrm{ft}$., $\$ 8.00$ 7058-Balled, 6 to 8 ft., $\$ 10.00$.

Pinus radiata Monterey Pine

A native of the California coast, very bushy when young with bright green foliage. It is the fastest grower of all pines. Ideal along the coast and it will grow readily inland, but is not so long-lived there. $60 \mathrm{ft} .8^{\circ}$

$6351-5$-gal. tins, $\$ 4.25$.

\section{The famous Deodar Cedar}

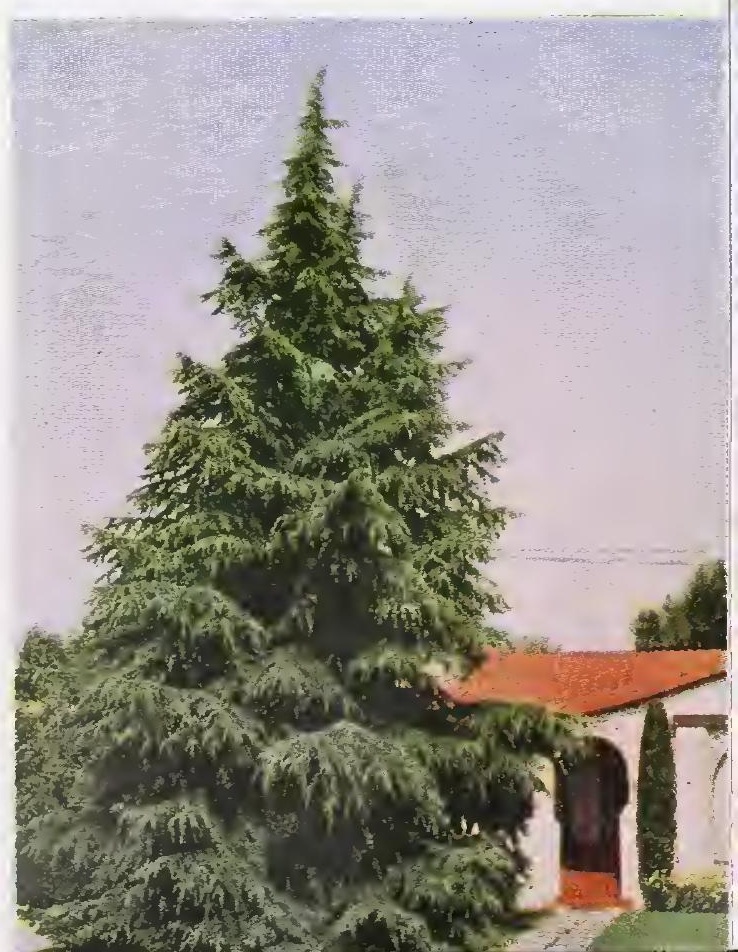




\section{Colorful Permanent}

On these two pages you will find plants which will bloom in your garden year after year without special care. They are much easier to grow than annuals, which have to be replanted every year. Many of them have evergreen tops, while some die down to the ground every winter and come up again in the spring. It is impossible in two pages to even mention many of the varieties of perennial flowering plants that we have at different seasons of the year. We list here only a few of the best. At any of our five salesyards you'll find many more varieties, as well as a complete supply of annual flowering plants.

Quantity Discount: You get a special discount on 10 or more of one variety, or Arctotis acaulis Hybrid Everblooming Daisy

One of the most popular perennials that we have ever offered is this bushy South African plant, 1 to 2 feet high and as much across. The plant is at its best in the winter and early spring, frequently carrying at one time 40 to 50 magnificent 3 -inch flowers in many brilliant shades ( see color illustration at left). Each plant is different in color, and we can't guarantee to furnish any exact shades. Almost everblooming. Plant in full sun. $15^{\circ} .4860-$ Gol. tins, $\$ 1.25$.

Everblooming Daisy (Arctotis)

Campanula poscharskyana Serbian Bellflower

We know of nothing finer as a border along the edge of the lawn, in front of shrubs, or hanging down over rocks or banks. It makes a beautiful little clump of violet-like evergreen foliage about 4 to 6 inches high and 12 to 18 inches across. For many weeks in early summer it is covered with hundreds of little starry, bell-shaped lavender-blue flowers about $1 \frac{1 / 4}{4}$ inches across. Shade or semi-shade. $10^{\circ}$ 4990-Gol. tins, $\$ 1.00$

\section{Aster Frikarti Wonder of Staefa}

Many consider it to be the country's finest perennial plant. It will provide a mass of lavender-blue flowers, 2 to $2 \frac{1}{2}$ inches across, from June 1st to December 1st, without a break. Not only a splendid show in the garden, but excellent for cutting. Grows easily anywhere. Full sun or part shade. $20^{\circ}$ $4865-$ Gol. tins, $\$ 1.75$.

\section{Bletilla hyacinthina Terrestrial Orcbid}

A delightful, easily grown outdoor orchid, with grassy foliage 1 to 2 feet high, bearing in the spring months a profusion of $11 / 2$-inch lavender-pink flowers with orchid and purple markings. Splendid for cut flowers. Full sun along coast, semi-shade elsewhere. $20^{\circ}$

4915-Gol. tins, $\$ 1.50$.

\section{Ceratostigma plumbaginoides}

Duarf Blue Plumbago

The deep rich blue flowers of this dwarf spreading plant, seldom over 8 inches tall, are welcome anywhere in the garden. Blooms in summer and fall, when its color is especially appreciated. Semishade or sun. $15^{\circ}$.

$5090-$ Gol. tins, $\$ 1.00$

Serbian Bellflower (Campanula poscharskyana)

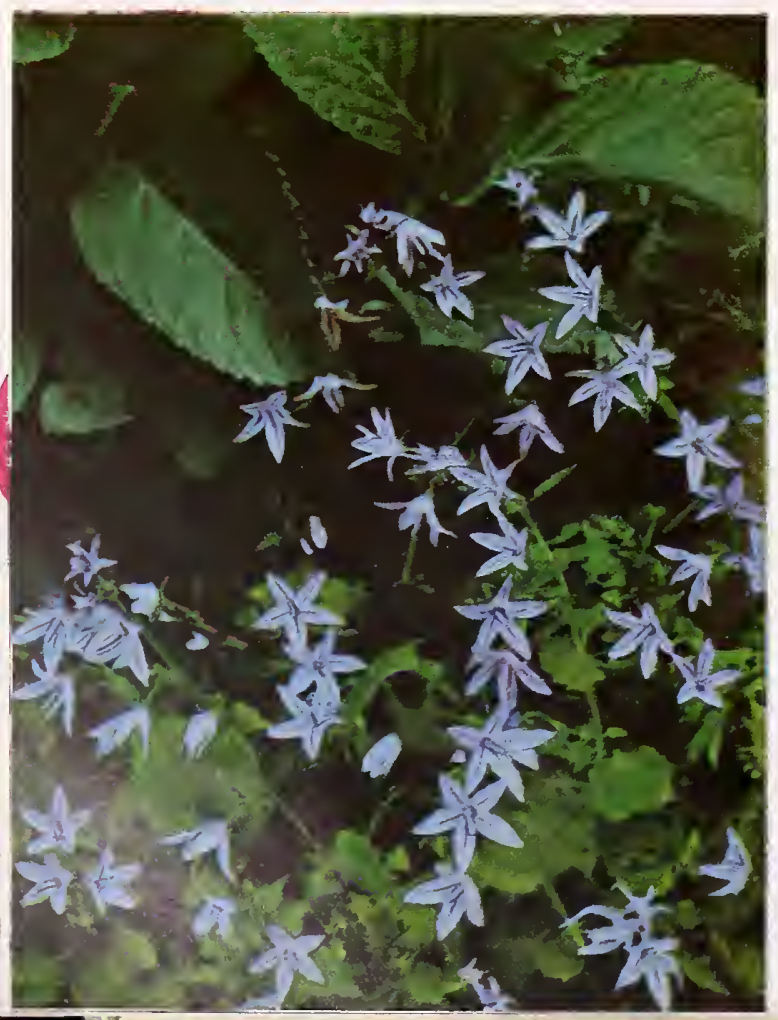

\section{Dimorphotheca ecklonis}

Star of the Veldt

Large spreading plant, 4 feet high and more across, with large, pale blue, 3 -inch flowers in late winter and spring. $30^{\circ}$. 5395-Gal. tins, $\$ 1.25$.

\section{Felicia aethiopica Compact}

You will be amazed at the brilliant display of blue and gold that this 12-inch. compact gem of a plant will provide all spring, summer and fall. The dainty, 1 . inch daisy-like blooms almost hide the plant, they are so numerous. This is a cutting-grown strain that we have selected ourselves. $15^{\circ}$. 5540-Gol. tins, $\$ 1.00$.

\section{Helianthus angustifolia}

Perennial Sunflower

A graceful clump of foliage 4 to 6 feet high is loaded with hundreds of brilliant goldenyellow flowers, 3 or more inches across. This is not the ordinary sunflower of the Blackeyed Susan type, but is a very graceful and attractive flower with its many finely cut petals, its dark center, and its bright gay color. Full sun. $15^{\circ}$. 5755-Gol. tins, $\$ 1.25$.

\section{Gerbera jamesoni Hybrids}

Transtaal Daisies

Gerberas are among the very finest of all flowers for cutting because of their gracefulness, lasting qualities, and bright colors Our selected strains are large-flowered and very long-stemmed. Full sun. $18^{\circ}$.

Mixed colors ranging from straw through pink, yellow, orange to brilliant scarlet and crimson. Bare root plants, October to May only, available during balance of the year in gal. tins. $5670-$ Gol. tins, $\$ 1.25$ $5672-$ Bore root, 3 for $85 c ; 6$ for $\$ 1.40$. 12 for $\$ 2.25 ; 100$ for $\$ 15.00$. Special selections, very large flowering types in separate colors: Red 5673. Salmon 5674. Yellow 5675. Pink 5676.

Bare root divisions only available from Oct, to May. $75 \mathrm{c}$ eoch; 3 of one color, $\$ 1.75$. 12 of one color, $\$ 5.75$.

\section{Heliotrope}

Nothing is more delightful than the scent of heliotrope in the garden. Throughout the summer and fall the plant makes lovely spot of garden color when loaded with its many fragrant purple flowers. They are good for cutting, too. Semi-shade. $30^{\circ}$ We have two kinds:

Heliotrope Queen Margoret. Royal Purple. 3200-Gol. tins, $\$ 1.25$ Heliotrope King of the Blocks. Rich dark violet. 3195-Gol. tins, \$1.25. 


\section{Herbs}

Mentha spicata Mint to you. For mint sauce, mint jelly, and mint juleps. $10^{\circ}$.

6125-Gal. tins, $\$ 1.00$.

Salvia officinalis Green Sage. The kitchen favorite. $10^{\circ}$. $6500-$ Gal. tins, $\$ 1.00$. Salvia officinalis variegata $A$ variegated sage. $15^{\circ}$. $6505-G a l$. tins, $\$ 1.00$. Thymus vulgaris Green Thyme. The favorite old fragrant-foliaged kitchen herb. Pretty little clump with lavender-blue flowers. $10^{\circ}$. 6615-Gal. tins, $\$ 1.00$.

\section{Kniphofia uvaria Red Hot Poker}

From an attractive clump of heavy, dark green, strap-like foliage come long stout upright stems, each one crowned with a fiery, 5 or 6inch, long, cone-like bloom. The brilliantly colored flowerhead is made up of innumerable lirtle firecracker-shaped flowers tightly packed together. Blooms in late summer and fall and provides a brilliant spot of "red hot" color in the garden. $15^{\circ}$. Rayal Standard is a brilliant orange-scarlet, 3 to 4 feet high.

5930-Gal. tins, $\$ 1.25$.

\section{Hemerocallis Daylily}

Popular in gardens the country over because they are extremely hardy, require little attention, and grow with ease in any well-drained soil. From a handsome clump of arching, sword-like foliage, the flower spikes rise of ten to 3 feet, to be crowned with big, magnificent, lily-like flowers. Although the individual blooms last only a day, they open continuously from spring until fall, and they will provide color as freely as anything you can plant. Many of them are fragrant, too. Plant them in sun or half-shade. They grow 2 to 4 feet tall and are hardy to about $10^{\circ}$.

All varieties belaw in gal. tins, $\$ 1.25$.

Calypsa Fragrant, 5- to 6-inch flowers of brilliant golden yellow. $\mathbf{5 7 6 5}$.

Gypsy Rich, deep golden orange, with deeper bronzy tones. $\mathbf{5 7 7 0 .}$

J. A. Crawfard Yellow, blended with apricot. A very delightful color which always attracts attention. 5775.

Mahagany Red One of the most brilliantly colored of all Daylilies. The very large flowers are a rich deep red, high-lighted with bronzy tones. $\mathbf{5 7 8 5}$.

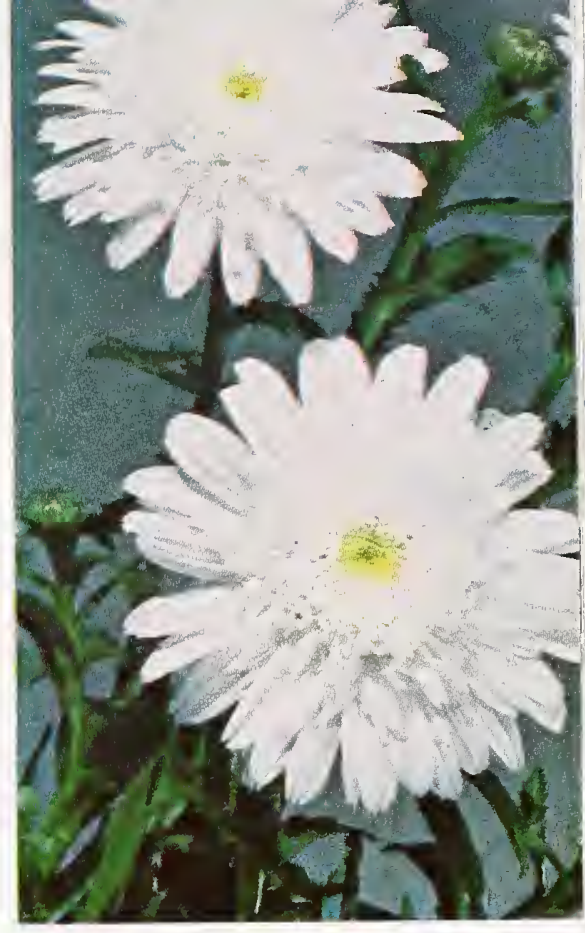

Shasta Daisy Esther Reed
Aster Frikarti

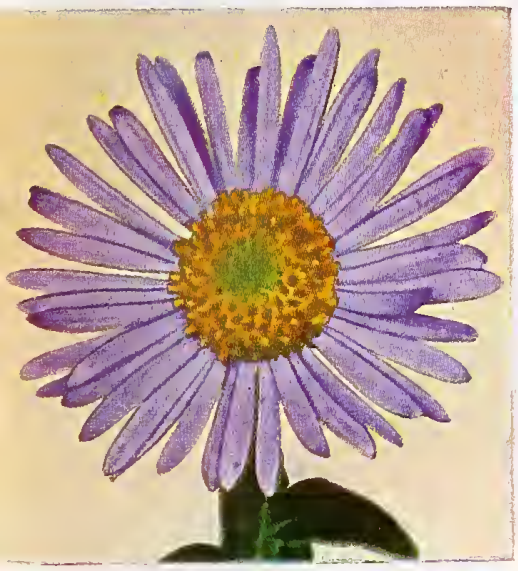

\section{Marguerites}

One of the most familiar and popular of the perennials. Free-blooming, fast-growing winter and spring-blooming plant with lots of showy daisy-like flowers. They grow 3 to 4 feet high. Plant in full sun. $30^{\circ}$. We have 2 varieties:

Single Yellaw. 6110-Gal. tins, $\$ 1.00$ Single Whire. $6105-$ Gal. tins, $\$ 1.00$

\section{Reinwardtia indica Yellow Flax}

A shrub in mild sections but dies down in the winter in colder areas. One of the finest winter and spring-blooming yellow flowered plants that can be grown; thrives in either sun or shade. Its large, 2-inch, bell-shaped, light yellow flowers make a splash of brilliant sunshiny yellow in the often colorless winter landscape. Grows 2 to 4 feet high. $15^{\circ}$.
6450-Gal. tins, \$1.25.

\section{Phlox}

For great masses of brightly colored bloom in summer and fall, and for cut flowers too, there is nothing better than these easily grown Phlox. $0^{\circ}$. Root divisions are sold from December to April. Bare-root divisians, 50c each; 3 far $\$ 1.30$ 12 far $\$ 4.75$ af ane variety.

Europa Pure white with red eye. 6279.

Leo Schlageter Orange-scarlet. 6281.

Morgenrood Rose-pink, scarlet eye. 6283 Mrs. Ethel Pritchard Clear mauve. 6285.

Salmon Glow Pink-shaded salmon. 6289.

San Antonio Carmine and plum-red. 6291.

Starlight Lavender with a white star. 6292.

\section{Morcaea iridioides Iris Moraea}

Iris-like plant with dark green strap-like foliage. From spring to late fall, it sends up many lovely white flowers marked with yellow and blue. Full sun. $15^{\circ}$.

\section{Shasta Daisy}

The new kinds listed below are becoming increasingly popular. They retain all of the good qualities of the familiar Shasta daisy, but the flowers are much more attractive. $15^{\circ}$.

Esther Reed $2 \mathrm{ft}$. A symmetrical pure white, medium sized double Shasta Daisy, with a full, white, double center. Cut blooms of this variety bring a better price $\begin{array}{ll}\text { on the cut flower market. } & 6535-G \text { al. tins, } \$ 1.00 .\end{array}$ Marconi Big, double, white chrysanthemum-like flowers on 21/2-foot stems. Full sun. $6540-$ Gal. tins, $\$ 1.00$.

\section{Statice perezi Sea Lavender}

Tufts of broad, silky leaves and immense candelabra-like heads of purplish blue flowers which can be cut and dried to keep indefinitely. Fine near coast. $10^{\circ}$ $6570-$ Gal. tins, $\$ 1.00$.

\section{Stokesia Blue Moon}

Immense, light blue, disclike flowers, 4 to 6 inches across on stiff 12 to 18 -inch stems. The plant grows quickly to 2 or 3 feet and blooms with great freedom Flowers last for ten days on the plant or cut. Full sun. $10^{\circ}$. $6580-$ Gal. tins, $\$ 1.00$

\section{Calla Lilies}

Zantedeschia aethiopica Wbite Calla Lily. The best and most free-blooming form of this favorite white flower. Splendid for a shady spot. $10^{\circ}$

6665-Gal. tins, $\$ 1.00$ Zantedeschia elliottiana Gold Calla Lily. The flowers are a rich golden yellow and the large leaves are flecked with silver. Available April to November. $10^{\circ}$

6670-Gal. tins, $\$ 1.00$

Zantedeschia aethiopica Baby White Dainty, miniature white blooms. Plant becomes only 12 inches high. $10^{\circ}$. $6660-4$-inch pats, $\$ 1.00$

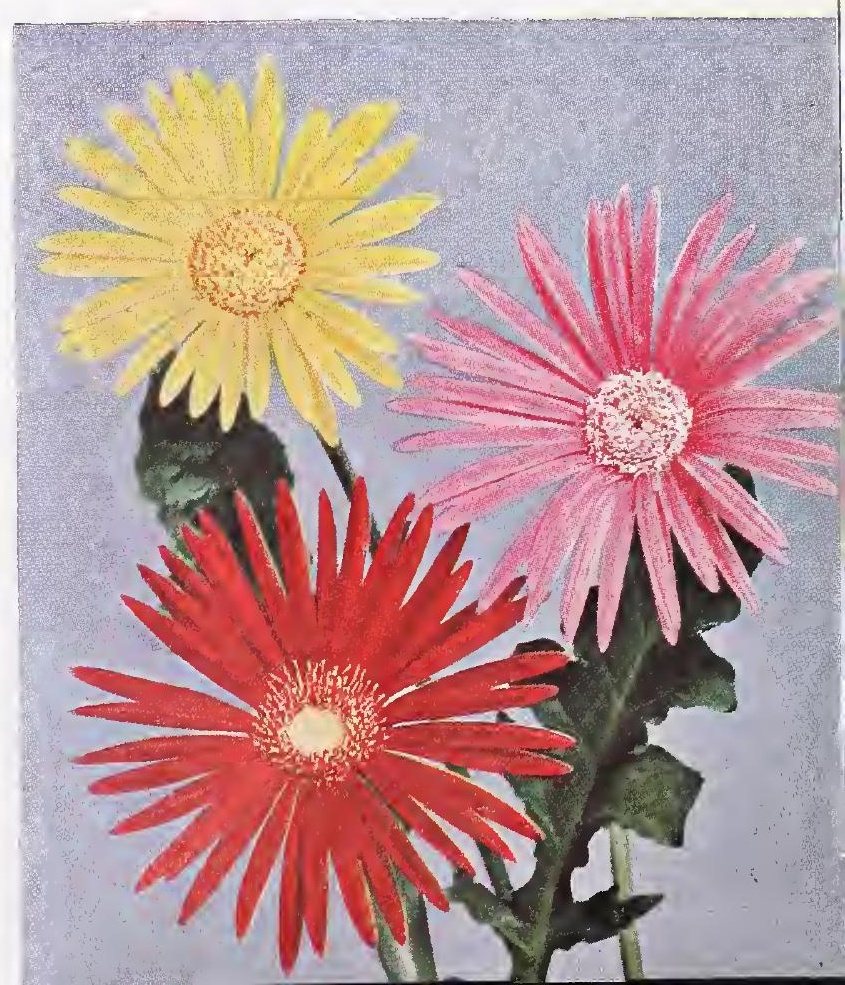




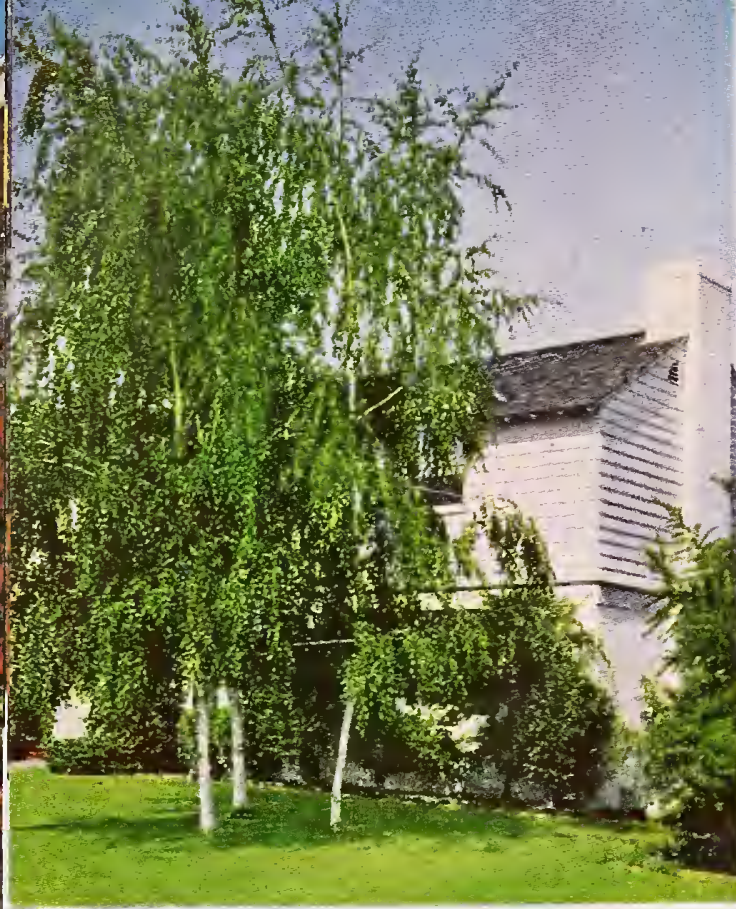

Picturesque clump of White Birch

\section{Deciduous Shade \&}

They Grow Anywhere These trees, which lose their leaves in winter, grow easily anywhere, including the desert regions. They give cool shade in summer but let the sunshine through in winter. Most of them grow quite rapidly. In addition to the sizes listed here we often have larger specimens of some kinds. See them in our display yards or write for sizes and prices.

When to Plant: As indicated on the calendar, most deciduous shade trees are available in the bare-root form only during the winter months. Some kinds are available in tins during the sum-

\begin{tabular}{|c|c|c|c|c|c|c|c|c|c|c|c|}
\hline Month & $\mathbf{J} \quad \mathbf{F}$ & M & A & $\mathrm{MJ}$ & $\mathbf{J}$ & $\mathbf{J}$ & & $S$ & $\mathrm{O}$ & & D \\
\hline Root & 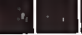 & & & & & & & & & & \\
\hline Tins & & & 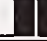 & & & & & & & & \\
\hline
\end{tabular}
mer.

Shipping Costs and Weights: On orders consisting entirely of bare-root material (tree roses excepted) shipping charges are paid by us to any point in the States. Plants in tins carry a $10 \%$ packing charge and are shipped by express or freight with the transportation charges collected from you. For truck delivery information and other shipping data, see page 3. 5-gal. tins weigh approximately 50 lbs.; gal. tins, 10 lbs., packed for shipment.

Quantity Discount: See page 31 for special discounts on quantities of 10 or more of a single variety or 25 or more assorted trees and shrubs.

Deciduous sbrubs and trees make bighly satisfactory garden plants and they fit well into California landscapes. Most of thent require very little care and unany of them will reward you witb a wealtb of bloom and a sbow of color ubicb just sbouts "Spring is bere."

\section{Acer saccharinum Silver Maple}

Many people from the East rate the Maple trees among the finest deciduous shade trees that can be grown. However, most of the eastern varieties do not do well on the Pacific Coast. This Silver Maple grows readily anywhere on the Pacific Coast, and in a short time makes a beautiful shade tree. Grows rapidly anywhere on coast, inland, or desert and it will put on a grand display of those glorious autumn colors every fall. Jikes plenty of water. 30 to $60 \mathrm{ft}$. $20^{\circ}$ below zero. 2780 -Bare root, 6 to $8 \mathrm{ft}$., $\$ 3.25$. 2781-Bare root, 8 to $10 \mathrm{ft}$., $\$ 4.00$. $2782-$ Bare root, 10 to $12 \mathrm{ft}$., $\$ 6.00$.

\section{Celtis occidentalis Hackberry}

A fine shade tree for the hot, dry southwestern country forming a large head of light green foliage. It is not affected by any insects or diseases, and grows in any soil and under all conditions. We recommend it highly for Imperial Valley, Arizona, Nevada, and all desert areas. 60 to $80 \mathrm{ft} .10^{\circ}$ below zero.

2795-Bare root, 6 to $8 \mathrm{ft}$., $\$ 3.25$. 2796-Bare root, 8 to $10 \mathrm{ft}$., $\$ 4.00$.

\section{Betula alba European White Birch}

Its picturesque white bark, dancing, shimmering foliage, and slender, graceful shape make the White Birch a favorite everywhere. It is particularly desirable near streams or pools, but also makes a beautiful little lawn tree. A group of three Birch trees planted at a corner of your lawn fits beautifully into the landscape picture. They grow just high enough to be a perfect foreground for the average California home. $30 \mathrm{ft} .20^{\circ}$ below zero. $6817-5$-gal. tins, $\$ 5.00$. 2786-Bare root, 8 to $10 \mathrm{ft}$., $\$ 5.25$.

\section{Betula pendula laciniata Cutleaf Weeping Birch}

This beautiful Weeping Birch is picturesque with its straight snowy white trunk from which the bark peels, its deeply cut leaves, and its slender pendulous branches. Just like the White Birch described above, these birches planted singly or in clumps create a pleasing landscape effect at any season of the year. $20 \mathrm{ft} .20^{\circ}$ below zero. $2790-$ Bare root, 5 to $6 \mathrm{ft}$., $\$ 4.50$. $6819-5$-gal. tins, $\$ 6.00$.

\section{Cotinus coggygria SmokeTree}

A handsome, small tree with good looking summer foliage, surmounted from July to October with many loose feathery panicles of minute purplish gray flowers. It gives the effect of a dense cloud of richly colored smoke. The leaves turn vivid golds and yellows in fall. Grows easily anywhere. Full sun. 12 to $15 \mathrm{ft} .0^{\circ}$.

2575-Bare root, 3 to $4 \mathrm{ft}$., $\$ 3.00$

\section{Cotinus coggygria Purple}

This rare little tree or large shrub has the most vividly colored foliage imaginable-a striking purple. During the summer and early fall the tree is crowded with flower panicles of a deeper, richer purple than those of the common Smoke Tree described above. Grow it anywhere in full sun. $5^{\circ}$. 5261-5-gal. tins, $\$ 8.50$

\section{Fraxinus velutina Arizona $A s b$}

One of the very finest trees for planting in the arid desert regions of the Southwest, because it requires very little water and thrives in alkaline soil. It is just as suitable for coastal areas, too. A fine medium sized tree, with bright green foliage. Growing with great rapidity, in a few short years it makes a handsome shade tree. $30 \mathrm{ft} .0^{\circ}$ $2801-$ Bare root, 6 to $8 \mathrm{ft}$. $\$ 3.50$.

$2802-$ Bare root, 8 to $10 \mathrm{ft}$., $\$ 4.25$. $2803-$ Bare root, 10 to $12 \mathrm{ft}$., $\$ 6.00$

\section{Fraxinus velutina coriacea Montebello Asb}

Our finest Ash for all sections, coast, valley, and desert. It has bigger, darker green foliage, a more dense, compact head, and is not attacked by that enemy of the Ash, red spider. Holds its foliage late in the fall, and comes out early in the spring. We have tried other improved types of the Ash which have been discontinued in favor of this. 25 to $30 \mathrm{ft} .5^{\circ}$

$$
\text { 2807-Bare root, } 8 \text { to } 10 \mathrm{ft} \text {., } \$ 4.50 \text {. }
$$

\section{Halesia carolina Snowdrop Tree}

In the spring every horizontal branch hangs full of little white bell-shaped flowers. They look just like little silver bells and you can imagine them tinkling as they sway in the breeze. Likes shelter from the hottest sun and plenty of moisture. Excellent for the edge of a lawn. 8 to $20 \mathrm{ft} .5^{\circ}$. 5718-5-gal. tins, $\$ 4.75$.

Liquidambar glows with autumn color

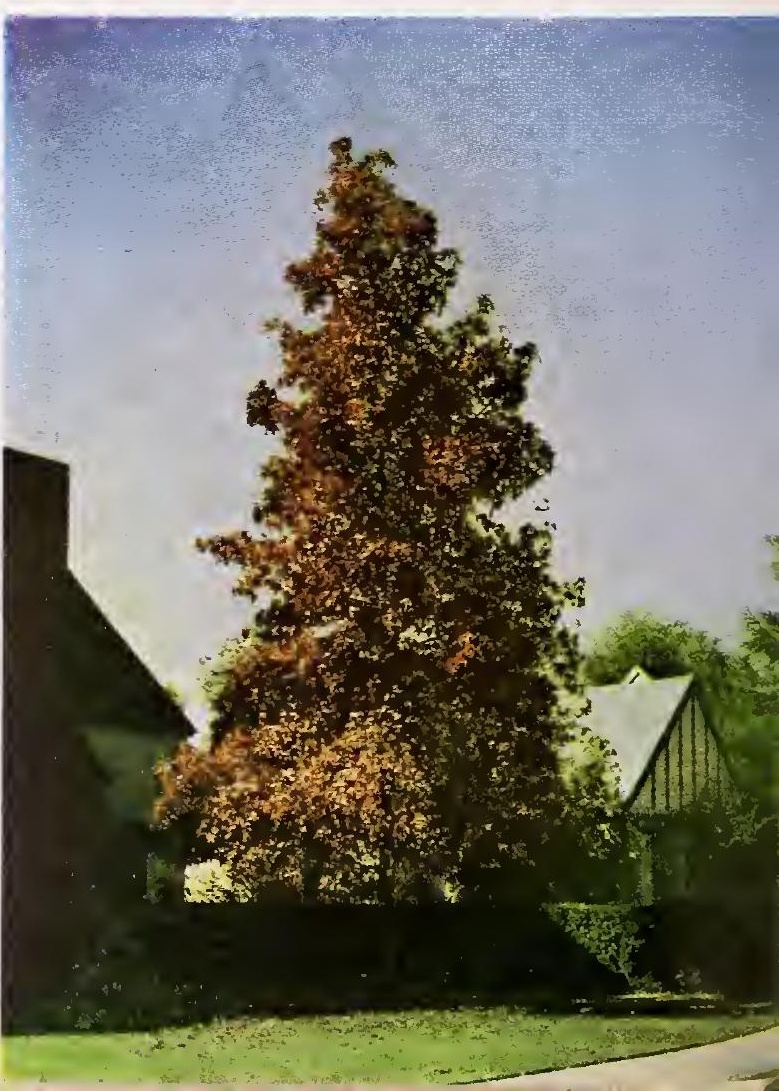




\section{Flowering Cherry}

\section{Prunus Shirofugen}

Every California garden should have at least one Flowering Cherry tree to welcome the spring, and there is none more spectacular than this variety. Every year it hails the arrival of spring by putting on a mag nificent show. Deep pink in the bud, the flowers open to fully double, carnation-like blooms of pale pink, and they literally cover every branch and twig like a blanket. The tree is easily grown and requires little care other than ample water. In warmer inland valleys it should be planted where it will have shade for at least a portion of the day. 2889-Bare root, $1 / 2$-inch caliper and up, $\$ 4.00$.

\section{Flowering Peaches}

For spring color few trees can match the Flowering Peaches. They grow with the greatest of ease anywhere and never fail to produce a mass of spectacular spring bloom. You can enjoy them in the garden or cut for indoor use. Hardy to $0^{\circ}$.

Prices on all varieties, except Altair: Bare raat, caliper $1 / 2$-inch up, $\$ 2.25$. Peppermint Striped pink, red, and white. Very showy. 2055

Early Red A spectacular ruby-red. 2060.

Pure White Immense snow-white blooms. 2065.

\section{Altair The New Fruiting-Flowering Peach}

The latest thing in flowering peaches, a product of the Armstrong Research Department, is the new Altair Peach, fully described on page 76. It belongs here, too, because it will give you big spectacular double pink flowers, the equal of any of the flowering kinds, but that's not all-every year you can pick a big crop of delicious freestone peaches. Before the advent of Altair, you had to choose between good bloom or good fruit. Now you can have both on only one tree.

$1950-1-y$ r. trees, caliper $1 / 2$-inch and up, $\$ 2.50$

\section{Flowering Crabapples}

Just one Flowering Crabapple in your garden can be so delightful and picturesque that its blooming period will be one of the most important garden events each spring. The small symmetrical trees are just right for the average home garden and they are hardy even below zero.

Prices on all varieties belaw: 1-yr. trees, $1 / 2$-inch caliper and up, $\$ 3.00$. 5-gal. tins, $\$ 4.25$.

Malus arnoldiana Arnold Crab. Dwarf and bushy, with very large rose-colored flowers, turning white as they age. 8 to $10 \mathrm{ft}$. $0^{\circ}$

2815-Bare root. 6835-5-gal, tins.

Malus halliana Hall's Crab. This variety is similar to the Arnold Crab above except that everything about it is larger. The tree grows larger and the bigger flowers are a deeper shade of rose-pink.

2817-Bare raat. 6836-5-gal. tins.

Malus ioensis Bechtel Bechtel's Double Rose-Flowering Crab. In early spring the small, rounded, bushy tree is covered with large fully double flowers. They look like roses in a soft delicate pink color and are deliciously violet-scented. 8 to $12 \mathrm{ft}$. 0

2820-Bare root. $\quad 6837-5$-gal. tins.

\section{Liriodendron tulipifera Tulip Tree}

A well-formed, deep-rooted, pyramidal tree which insects and decay never bother. In the spring tulip-like flowers of yellowish-orange shine out against the big uniquely notched leaves. Most attractive in the fall when the foliage turns to shimmering gold. $75 \mathrm{ft} .20^{\circ}$.

$2810-$ Bare raot, 4 to 6 ft., $\$ 4.25$. $\quad 6036-5$-gal. tins, $\$ 4.75$.

\section{Liquidambar styraciflua Sweet Gum}

This is one tree which provides just as much color in the fall in California as it does in the East. If you want to bring those gorgeous red and bronze autumn colors into your garden in November and December, this tree with its big maple-like leaves will do it for you. The tree grows into a slender attractive pyramid, splendid for a small parkway tree and fine for the small garden. Thrives anywhere from the ocean front to the desert valleys. $30 \mathrm{ft}$. $0^{\circ}$.

$$
6031-5 \text {-gal tins, } \$ 4.75 \text {. 6032-16-inch bax, } \$ 20.00
$$

7006-Balled, 4 to $5 \mathrm{ft}$., $\$ 5.50$. 7007-Balled, 5 to $6 \mathrm{ft}$., $\$ 7.00$ 7008-Balled, 6 ta 8 ft., $\$ 9.00$. 7009-Balled, 8 to $10 \mathrm{ft}$., $\$ 15.00$

A number of the deciduous shade trees described on these two pages and the next can be grown satisfactorily in the desert areas. Amons the best are: Arizona Ash, Chinese Elm, European Sycamore, Hack berry, Kingan Mulberry, Thornber Cottonwood, and the Umbrella.

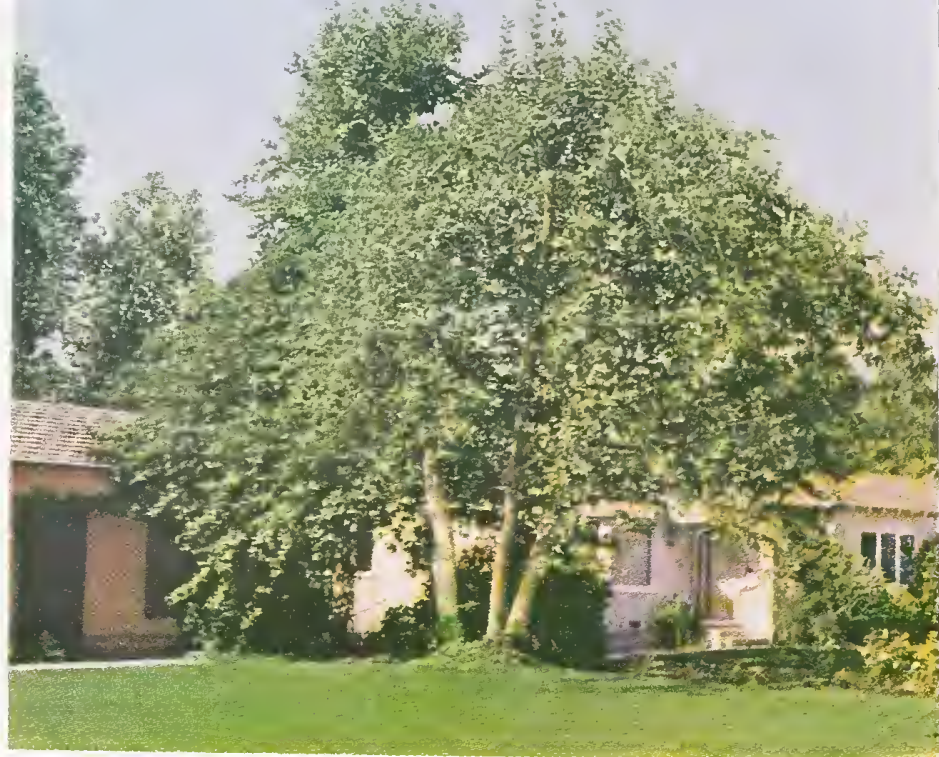

Picturesque native California Sycamore clump. See page 70

\section{Crepe Myrtles}

Lagerstroemia indica During the hot summer days of July, August, and September, the Crepe Myrtles are masses of brilliant color. They do not bloom so well directly on the coast, but in the inland valleys of California their crinkled, crepelike flowers are produced in great profusion. The large kinds become almost treelike, and they make fine ornamental shrubs or small trees in the home garden. Plan them in a corner by wall or fence, and with very little care they will reward you all summer long with a profusion of bloom. Hardy to $12^{\circ}$.

Pink Crepe Myrtle Lovely pastel pink. 10 to $20 \mathrm{ft}$. 5950-Gal. tins, \$1.75. 5951-5-gal. tins, \$5.25.

Red Crepe Myrtle Rich watermelon-red. 10 to $15 \mathrm{ft}$. 5955-Gal. tins, \$1.75. 5956-5-gal. tins, \$5.25.

White Crepe Myrtle Big, snowy white blossoms. Rarely seen because it is difficult to propagate. Ours are grafted plants. 5960-Gal. tins, \$1.75. 5961-5-gal, tins, \$5.25.

Dwarf Blue Crepe Myrtle A beautiful dwarf lavender-blue. 8 to $10 \mathrm{ft}$. 5940-Gal. tins, \$1.75. 5941-5-gal. tins, $\$ 5.25$.

Dwarf Red Crepe Myrtle A spectacular rosy red. Grows only 8 to $10 \mathrm{ft}$ $5945-$ Gal tins, $\$ 1.75$.

\section{Melia azedarach umbraculiformis}

Texas Umbrella A splendid fast growing tree for either coastal regions or hot interior valleys. The branches radiate from the trunk to form a large, rounded umbrella, densely covered with fernlike leaves. In summer it hangs full of large panicles of lavender flowers. $30 \mathrm{ft} .0^{\circ}$.

2830 -Bare root, heavy, well-branched, 4 ta $6 \mathrm{ft.}, \$ 4.25$.

Colorful Crepe Myrtle makes a handsome small tree

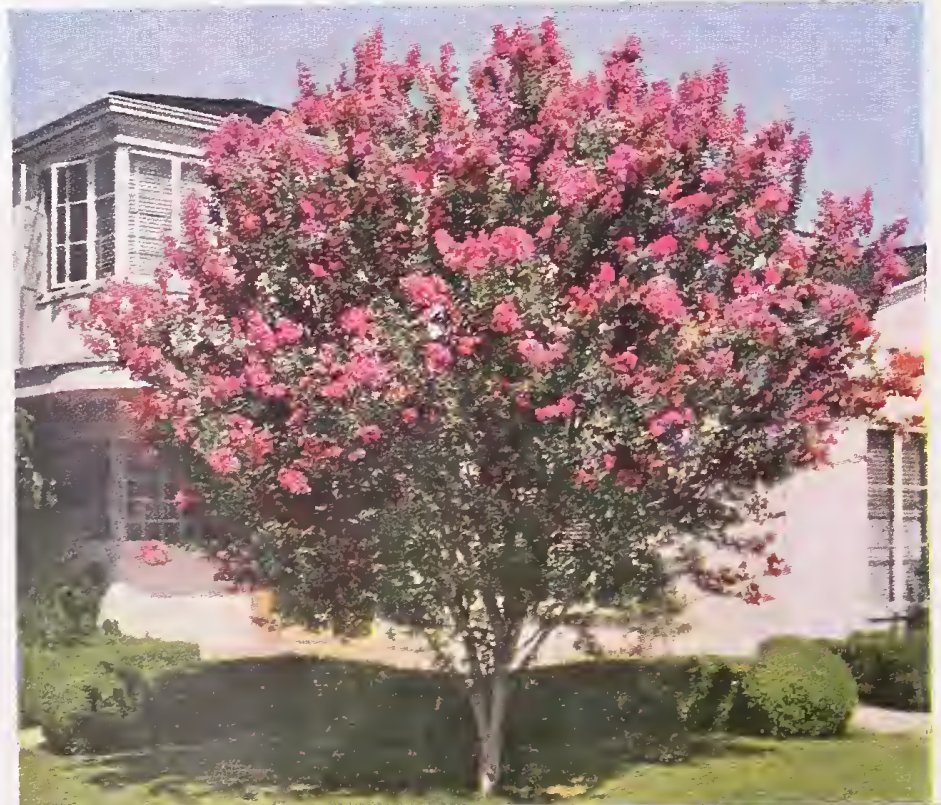




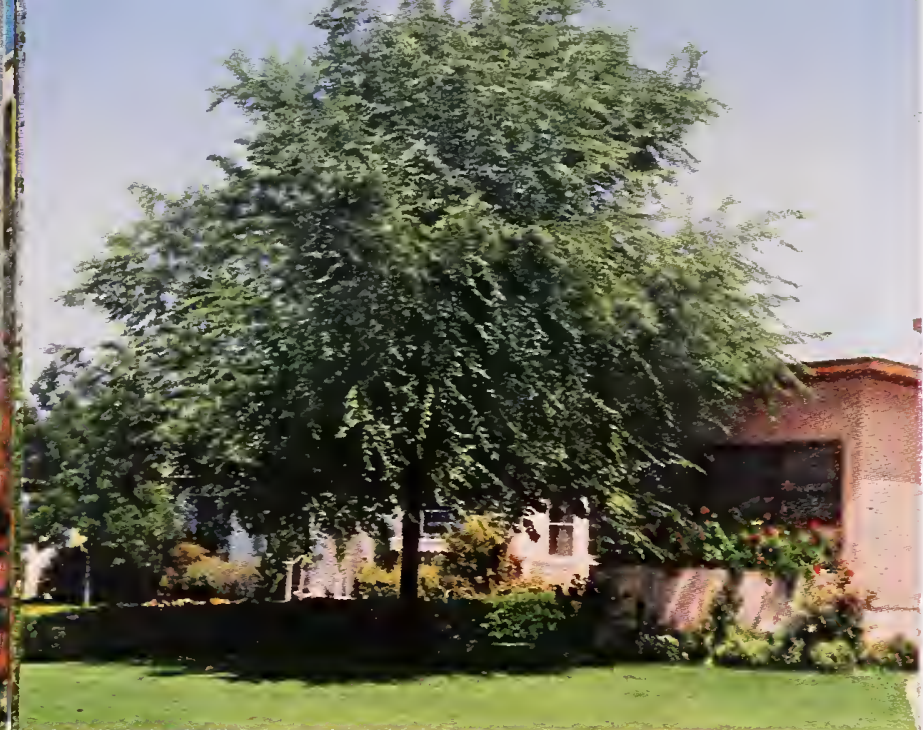

The extremely fast-growing Chinese Elm

Pistacia chinensis Chinese Pistacbio

A very handsome and fast growing tree with a good-looking round head and attractive long-pointed leaves. In the fall even in Southern California, the foliage turns to brilliant glowing hues of scarlet, crimson, and yellow. Grows easily anywhere from seacoast to desert. $50 \mathrm{ft}$ $15^{\circ}$. $2856-$ Bare rooł, 6 to $8 \mathrm{ft}$., $\$ 4.25$

\section{The Mulberries}

\section{Morus nigra Persian Mulberry}

If you enjoy your mulberries 2 inches long, juicy and aromatic, this is the variety to plant. It has the finest fruit of all mulberries and is splendid to eat fresh or for pies, juice or preserves. Its small size and big, luxuriant, bright green leaves make it a splendid garden tree. 10 to $15 \mathrm{ft}$. $20^{\circ}$ below zero

$2846-8$ are root, 3 to $4 \mathrm{ft} ., \$ 3.50$.

Morus rubra 'Hick's Mulberry'

A strong, upright, fast growing tree which thrives anywhere. 1t broad handsome foliage quickly makes shade and the tree never fails to bear good-sized delicious black berries. Usually there will be plenty of fruit for you, the children, and the birds, too. $40 \mathrm{ft}$ $20^{\circ}$ below zero.

$2851-8$ ore root, 8 to $10 \mathrm{ft}$., $\$ 4.25$. 2852-Bore root, 10 to $12 \mathrm{ft} ., \$ 6.00$.

\section{Morus Kingan Fruitless}

One of the finest of all shade trees, even for desert sections, for it gives dense shade in an amazingly short time and will stand any amount of heat, drought, cold and alkali. This variety is absolutely fruitless, so it is fine for planting as a street tree or in garden locations where fruit would be undesirable. 3 ft. $5^{\circ}$ below zero.

$2841-8$ ore root, 8 to $10 \mathrm{ft}$., $\$ 4.25$. $2842-8$ ore root, 10 to $12 \mathrm{ft}$., $\$ 6.00$. $6843-5$-gol. tins, $\$ 4.25$

\section{Deciduous Shrubs}

You can enjoy these hardy spring flowering shrubs no matter where you live. Bare root plants are available for planting from January to April, only. Those listed in tins or as balled plants are available throughout the year.

\section{Flowering Quince}

\section{Flowering Quince}

Place one or two branches of Flowering Quince informally in a vase and you will have long lasting natural flower arrangement which everyone thinks is perfect. In California they bloom right in the middle of winter. A plant in the garden, of course, is a magnificen sight. The plants have handsome glossy foliage throughout the summer. Plant in full sun. Hardy down to $0^{\circ}$.

All varieties listed below, bore root, 2-yeor plonts, $\$ 3.00$ each. 5-gal. tins, $\$ 4.25$ eoch

\section{Chaenomeles Rosea Grandiflora Rose Flowering Quince}

The earliest deciduous shrub to flower. In California you can have their brilliant rosyred flowers in January. In colder climates they bloom a little later. $6 \mathrm{ft} .0^{\circ} . \quad 2565-8$ are root.

\section{Chaenomeles Apple Blossom}

6827-5-gol. tin.

In very early spring each twig is full of deep pink buds which suddenly burst into beautiful big blooms of dainty apple-blossom-pink and cream. See illustration at right $6 \mathrm{ft} .0^{\circ}$.

\section{Chaenomeles Rubra Grandifora Red Flowering Quince}

The irregular bush is a glorious sight in midwinter when covered with bright pink buds and immense blood-red flowers. $6 \mathrm{ft} .0^{\circ}$.

\section{Shade Trees}

s nigra italica Lombardy Poplar tor accentuating certain types of archirecture.

Populus fremonti Thornber Thomber Cottonuood A very fine fast growing large spreading tree, particularly for inland A desert sections. It has very large handsome foliage and the typical white bark of the familar Cottonwood. Its outstanding feature entire lack of the bothersome "cotton" so objectionable on many $2875-$ Bare root, 4 to $6 \mathrm{ft}$., $\$ 3.50$ $2876-8$ ore root, 6 to $8 \mathrm{ft}$., $\$ 4.25$.

\section{Platanus acerifolia European Sycamore}

London Plane." Its rapid growth, large, bright green, maple-like Bore root, 6 to $8 \mathrm{ft}$., $\$ 3.25$. $2862-$ Bore root, 8 to $10 \mathrm{ft}$., $\$ 4.25$.
2863 -Bare root, 10 to $12 \mathrm{ft}$., $\$ 6.00$. $6845-5$-gol. tins, $\$ 4.25$.

\section{us racemosa California Sycanore}

The picturesque green foliage and irregular mottled white trunk make 2-year "clumps" which branch at the ground. These much more picturesque for certain settings. $60 \mathrm{ft}$. $0^{\circ}$

6 to $8 \mathrm{ft}$., $\$ 3.25$. 2872-Bore root, 8 to $10 \mathrm{ft}$., $\$ 4.25$. 6847-5-gol. tins, \$4.25. 2865-Clumps, 2-yr., \$6.50.

Salix babylonica Weeping Willow

The picturesque well-known tree that has been popular the world over $2890-$ Bore root, 6 to $8 \mathrm{ft}$., 53.50

\section{Ulmus parvifolia Chinese Elm}

Welling tree, too, with fine compact foliage and a $5 \mathrm{ymmetrical}$ Well adapted to the dry interior sections, since it does well in whe planted anywhere and which will be certain $2895-8$ ore root, 6 to $8 \mathrm{ft}$., $\$ 2.75$. . $2898-$ Bore root, 12 to $14 \mathrm{ft}$., $\$ 6.50$. $\quad 6860-5$-gol. tin, $\$ 3.75$.

Ulmus americana American White Elm

most beautiful and majestic of all native American trees, great arching branches clothed with bright green foliage growing but longer lived than the Chinese Elm. Grows easily

$2893-$ Bare root, 6 to $8 \mathrm{ft}$., $\$ 3.50$

Flowering Quince, Apple Blossom 


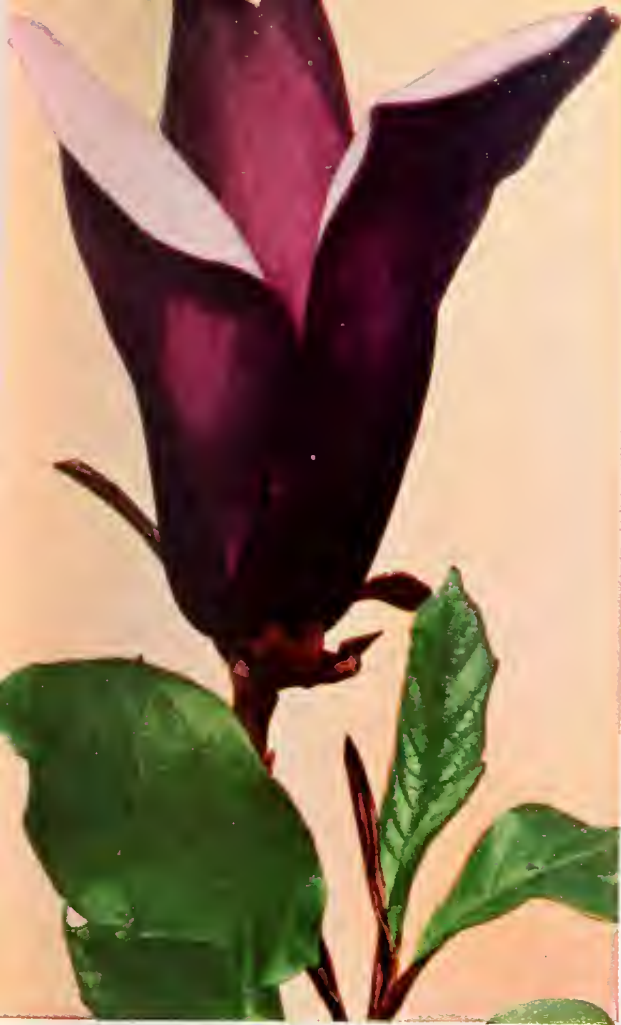

Purple Lily Magnolia
Chilopsis linearis Desert Willow A surprising native California plant from the hottest, sandiest parts of the Southern California desert. Looks like a small willow but breaks out in the summertime with lovely orchid-like, trumpet-shaped flowers, 2 inches long, in delicate but brilliant shades of lilac, lavender and yellow. Easily grown anywhere. Full sun. Dry soil. 10 to $15 \mathrm{ft} .5^{\circ}$

$$
\text { 5130-Gal. tins, \$1.75. }
$$

\section{Chimonanthus praecox}

IVintersweet

In midwinter when flowers are scarce it bursts into cheery bloom. The waxy, 1 -inch, pale yellow flowers resemble a diminutive magnolia bloom and they scent the air with a sweet violet-like perfume. Charming in the garden or as cut sprays for the house. Grows anywhere. Sun or part shade. $6 \mathrm{ft}, 10^{\circ}$

$$
\text { 5135-Gal. tins, } \$ 1.75 \text {. }
$$

Kolkwitzia amabilis Beautybusb A fine hardy flowering shrub from Central China. In the spring it forms a beautifully foliaged bush. Fountain-like in habit, every branch becomes a plume of lovely bell-shaped pink blossoms. Extremes of heat, cold and wind do not bother it, and it will thrive almost anywhere in sun or shade. 6 to $8 \mathrm{ft} .0^{\circ}$.
Hibiscus syriacus Coelestis

Rose-of-Sbaron

This hardy hibiscus makes a large shrub with big 3-inch blooms of rich blue-one of the finest shades of blue to be found in flowers. Rose-of-Sharon is a familiar sight in the Southern and Eastern States but does just as well anywhere else, including California. Sun. $8-10 \mathrm{ft}$. $0^{\circ}$. $\quad 5800-$ Gal. tins, $\$ 1.25$

\section{Hydrangea quercifolia}

Oakleaf Hydrangea A beautiful and striking shrub with its large 8 -inch leaves, three-lobed like an oak leaf, and the great 12 to 14-inch heads of big, white flowers which appear in early summer. The leaves are so big and lush looking that they give a tropical appearance to the plant even though they will stand many degrees of frost. Must have shade and a reasonable amount of moisture. $6 \mathrm{ft}$. $5^{\circ}$. 5831-5-gal. tins, $\$ 5.25$.

\section{Neillia longiracemosa}

A new and delightful hardy flowering shrub from China. Slender and arching, the branches, clothed with bright green grape-like leaves, form a very attractive plant and one not too large for any garden. In spring, slender clusters ( 6 to 10 inches long) of charming little pink bell-shaped flowers hang from every
branch. Part shade. $6 \mathrm{ft}$. $5^{\circ}$.

6165-Gal. tins, $\$ 1.75$

\section{Magnolias for Spring Bloom}

In gardens all over the world deciduous Magnolias are admired for their beautiful burst of spring bloom which appears before the leaves. The mass of gorgeous fragrant flowers is one of the most welcome heralds of spring.

\section{Magnolia soulangeana Saucer Magnolia}

A magnificent big cup-shaped bloom, often as much as 7 or 8 inches across. The waxy petals are a creamy white, delicately suffused with pink. A very good-looking small tree or large shrub, with big bright green foliage throughout the spring, summer and fall. In the late winter just before the new leaves appear it is a thing of breathtaking beauty when covered with great quantities of the huge spectacular flowers. 8 to $10 \mathrm{ft} .10^{\circ}$. 6072-5-gal. tins, $\$ 9.00$.

7028-Balled, 3 to $4 \mathrm{ft}$., $\$ 15.00$. $7029-$ B $\approx l l e d, 4$ to $5 \mathrm{ft}$., $\$ 17.50$.

\section{Magnolia liliffora Purple Lily Magnolia}

This particular kind is just the right size for the average garden, and it blooms profusely. The plants are covered for almost 3 months in March, April and May with the beautiful flowers. They become 51/2 inches across when fully open, rich reddish purple on the outside and creamy white inside. The illustration above only hints at the spectacular beauty of the fiower. $8.10 \mathrm{ft} .10^{\circ}$ 7026-Balled, 3-4 ft., $\$ 12.50$.

7027-Balled, 4-5 ft., $\$ 15.00$.

\section{The Fragrant Philadelphus}

\section{Philadelphus lemoinei Belle Etoile \\ Purple Spot Pbiladelphus \\ One of the most beautiful late spring flowering shrubs for California and nearly every other section of the country, too. Growing 5 or 6 feet high, it will fit easily into almost any garden. The saucer-shaped flowers are snowy white, about $11 / 2$ inches across and each petal has a distinctive little purple spot at its base. In May and June the arching stems are loaded with blooms which fill the garden with a rich heady perfume. $6 \mathrm{ft} .0^{\circ}$ $6260-$ Gal. tins, $\$ 1.25$. $6261-5$-gal. tins, $\$ 4.25$.}

\section{Philadelphus virginalis Virginal Mock Orange}

A greatly improved form of Philadelphus with enormous snowy white flowers. The 3-inch flowers are so surpassingly fragrant that they perfume the air for many feet around the plant. It is one of the most delightful spring flowering shrubs, its great show of blooms every spring being an outstanding garden event. The cut sprays make wonderful indoor decorations that are fragrant and long-lasting. Grows easily anywhere in sun or part shade, requires only moderate moisture. Blooms from May to June. $6-8 \mathrm{ft}$. $0^{\circ}$ $6270-$ Gal. tins, $\$ 1.25$. 627l-5-gal. tins, $\$ 4.25$.

\section{Magnolia stellata Star Magnolia}

A charming dwarf Magnolia, first to bloom in the spring. The delightful 3-inch blooms have 12 to 18 narrow, snowy petals which look as if they had been cut from white suede. Blooms profusely when very young. $5-8 \mathrm{ft}$. $10^{\circ}$. $6086-5-\mathrm{gal}$. tins, $\$ 9.00$.

\section{Magnolia stellata Pink}

A rare Magnolia with all the fine characteristics of Magnolia stellata except that the flowers are a rosy pink, fading to lighter and more delicate shades as they age. A little slower growing than Magnolia stellata but blooms profusely while young. $8-12 \mathrm{ft} .10^{\circ}$.

$6091-5$-gal. tins, $\$ 9.00$

\section{Spectacular flowers of Magnolia soulangeana}




\section{Armstrong Deciduous Fruits}

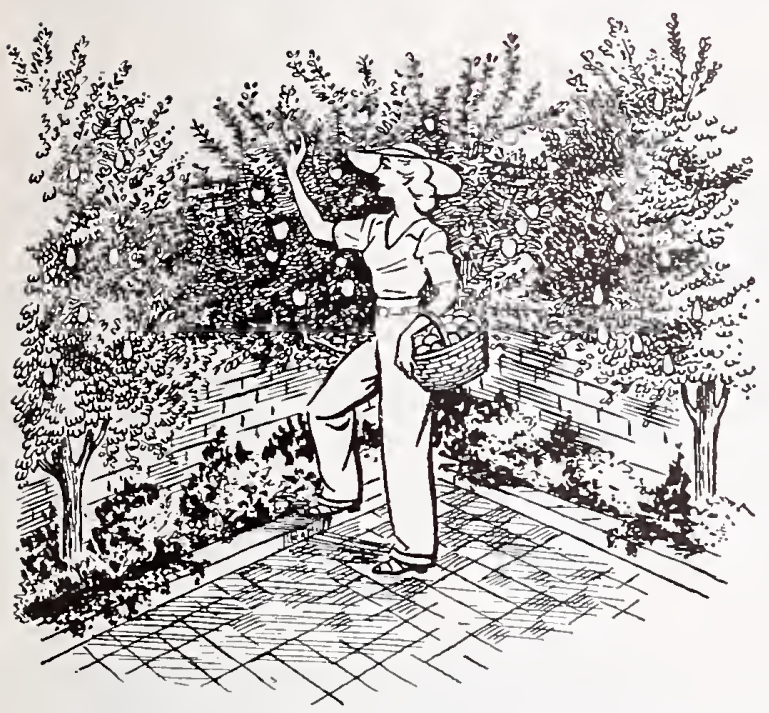

\section{Fruit in the Garden}

It is amazingly easy to get plenty of delicious fruit for home use from any home garden in Southern California even though the garden may be small. It is not necessary to have an acre or two of ground or even a large lot to enjoy home grown fruit. With a little planning and a few tricks of pruning, you can make use of odd corners, neglected spaces, bare walls or fences to get fruit for all the family to enjoy-and it takes no expert care or knowledge.

\section{Armstrong Quality}

Since the very beginning of the Armstrong Nurseries, over 60 years ago, fruit trees have been one of our very important crops. Today we are just as anxious as we always have been to grow and send to you only the finest fruit trees that it is possible to grow. You may select any fruit trees from this list and be sure that you are getting the finest quality you can buy at any price.

\section{Shipping Costs}

We prepay the transportation charges on all orders consisting entirely of bare-rooted material when shipped to any point in the States by mail, express or freight. For truck delivery information in Southern California, see page 3.

\section{When to Plant}

Deciduous fruit trees may be safely transplanted without soil on the roots during their dormant period in January, February and March. They can be handled in this manner only during those three months and are not available at any other time of the year.

Month
Bare Raat

\section{Planting Distances}

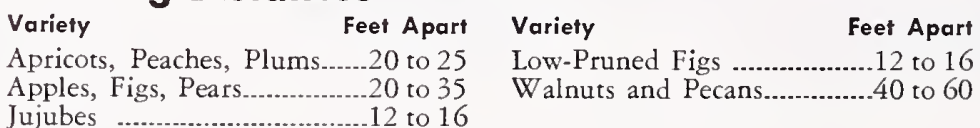
For furtber planting information see page 30 .

\section{Planting Instructions}

Deciduous fruit trees of all kinds become established more quickly and there is less danger of loss if they are severely pruned before planting. In most cases smaller lots of fruit trees sent out for home planting will be properly pruned before shipment.

The complete planting instructions which accompany each order should be carefully read before you plant. Follow them carefully and you will profit by greater planting success.

\section{Armstrong Apricots}

To enjoy the mellow goodness of early ripening apricots to the fullest extent, you should be able to pick them from your own trees, fully ripened in the sun. The apricot is a very handsome shade tree which grows rapidly and produces regular crops without cross-pollination. All apricot trees, 1-yr., caliper $3 / 8$ inch and up.

\section{Moorpark The Fruit of Higbest Quality}

You will find no apricot better than this one in quality, although it is considered a somewhat irregular and shy bearer in the interior valleys; in the coastal belt it is much better. The fruit is extremely large, deep orange in color, with a dark red blush on the sunny side. Very juicy and firm, the bright orange flesh has an unbelievably delicious flavor. Early July.

$1815-\$ 1.75$ each, $\$ 15.50$ per 10.

\section{Reeves Best for Soutbern California}

For many years we have been searching for a large, fine-flavored apricot which could be counted upon to bear good crops every year in our Southern California climate, for here most of the older apricot varieties produce light or irregular crops. Our search has been rewarded with the new Reeves, which was discovered several years ago in Glendale, California. Thoroughly adapted to our mild winter climate, we believe Reeves will produce plenty of fruit every year. It has the very valuable quality of ripening extremely early, several weeks before Royal, when apricots are very scarce. The big, round, orange-yellow fruits, with their delightful rosy blush, are beautiful to look at, and the delicious fullflavored flesh melts away as you eat. An ideal home apricot. Plant Pat. No. 693.

$1820-\$ 2.25$ each, $\$ 20.00$ per 10

\section{Royal The Leading Commercial Variety}

This has long been the leading California apricot for commercial planting and for the home. The fruit is of good size, highly colored, often with a bright red cheek, and the flesh is deep orange, rich, sweet and delicious. Royal is a fine apricot for all sections and the most dependable bearer among the standard apricot varieties. It ripens 2 to 4 weeks after Reeves. Late June.

$1825-\$ 1.75$ each, $\$ 15.50$ per 10.

\section{Protect Your Trees}

Tree protectors should be used on all deciduous fruit trees when they are first planted. They prevent sunburn which is detrimental to the trees, and is a starting place for tree diseases and insect injuries. Protectors cost but a few cents and are valuable insurance. Listed on page 100.

\section{Tilton}

The beautiful big heart-shaped fruits are among the largest of all apricots. The fruit ripens evenly and is always a deep rich orange apricot in color. The variety does not bear well in coastal regions, but the vigorous trees bear abundant crops of richly flavored, highly colored fruit in the warm interior valleys. Ripens in early July. $1830-\$ 1.75$ each, $\$ 15.50$ per 10 .

The new Reeves Apricot-finest for Southern California

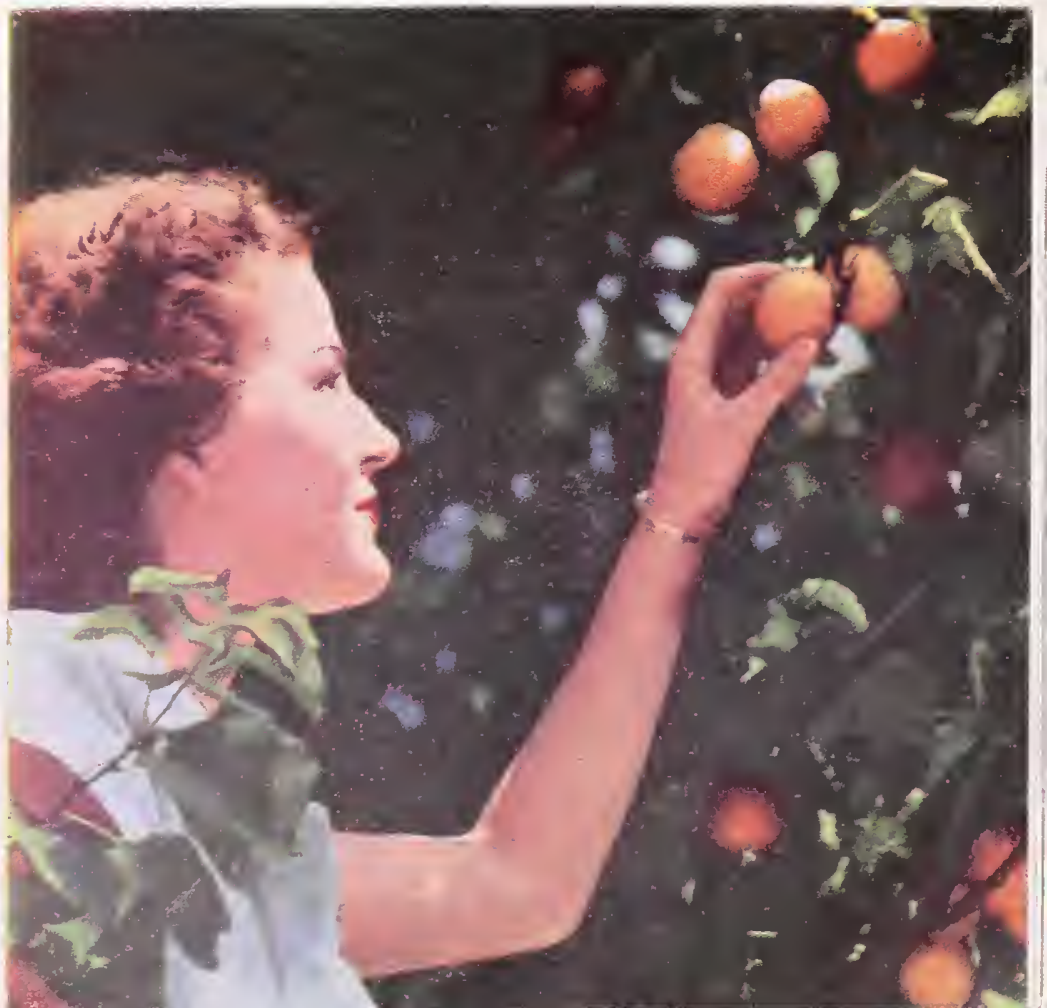



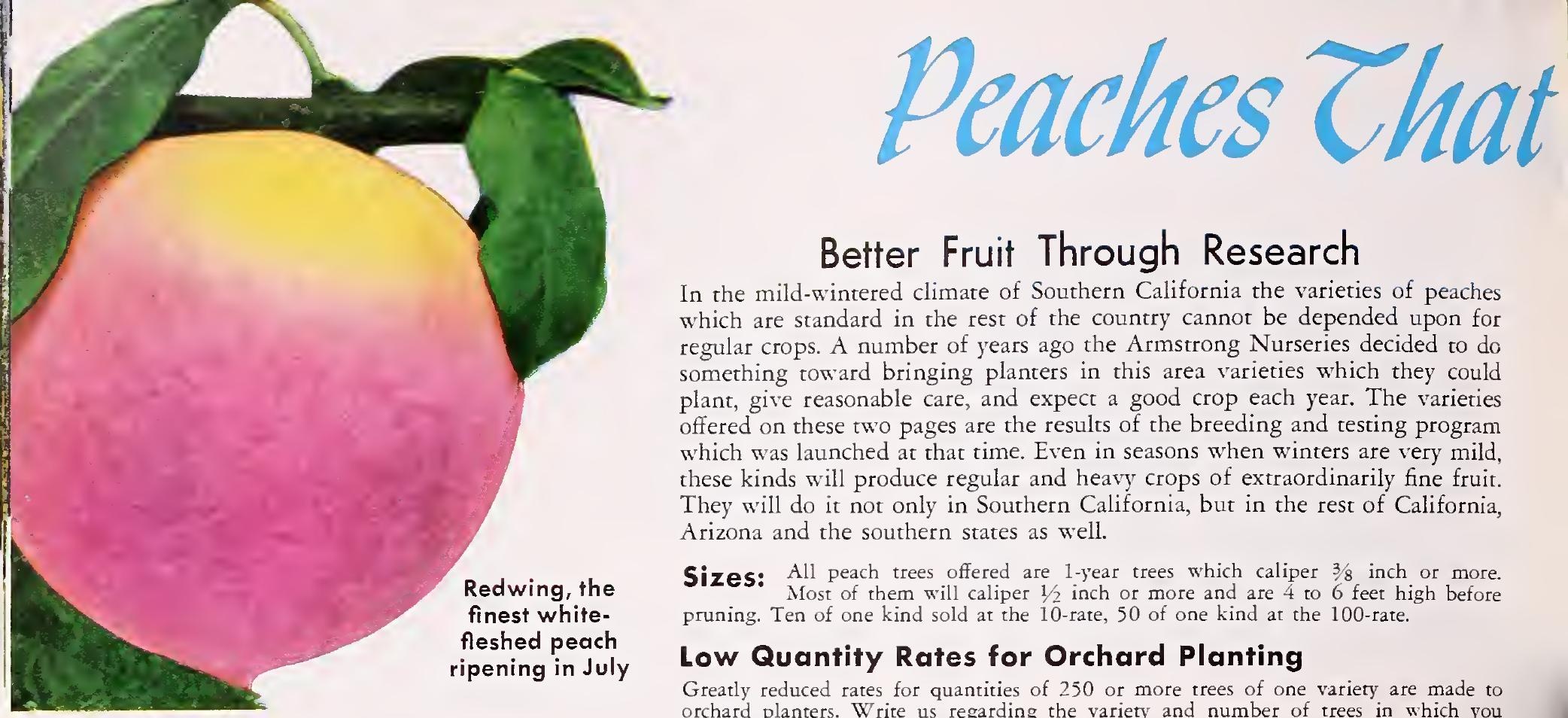

\section{Better Fruit Through Research}

In the mild-wintered climate of Southern California the varieties of peaches which are standard in the rest of the country cannot be depended upon for regular crops. A number of years ago the Armstrong Nurseries decided to do something toward bringing planters in this area varieties which they could plant, give reasonable care, and expect a good crop each year. The varieties offered on these two pages are the results of the breeding and testing program which was launched at that time. Even in seasons when winters are very mild, these kinds will produce regular and heavy crops of extraordinarily fine fruit. They will do it not only in Southern California, but in the rest of California, Arizona and the southern states as well.

Sizes: All peach trees offered are 1 -y'ear trees which caliper $3 / 8$ inch or more. Most of them will caliper $1 / 2$ inch or more and are 4 to 6 feet high before pruning. Ten of one kind sold at the 10-rate, 50 of one kind at the 100-rate.

\section{Low Quantity Rates for Orchard Planting}

Greatly reduced rates for quantities of 250 or more trees of one variety are made to orchard planters. Write us regarding the variety and number of trees in which you are interested and we will gladly send a quotation by return mail.

\section{Robin The Early High-Profit Peach}

It is the first good peach of the season-that fact alone puts Robin in a class by itself. It ripens weeks before any other good early peach and the crops are enormous. It is small wonder that this Armstrong introduction has achieved the commercial importance which we predicted for it at the time of its introduction.

Robin is a beautiful red-cheeked, white-fleshed, medium-sized fruit, semi-freestone, so richly flavored and handsome that it will make your mouth water just to look at it. Deliciously flavored, the fruit is firm and smooth, almost fuzzless, and round in shape. For a peach of this type it keeps extremely well after picking. In addition to ripening the first good peaches of the season, Robin trees bear enormous crops. They grow rapidly and bear fruit amazingly soon-sometimes the first year after planting.

Nothing tastes so good as the first fruit of the season, and with a tree of Robin in your home garden planting you can enjoy it to the fullest extent. If you have a piece of vacant land suitable for a peach orchard, you will be interested in the fact that Robin has consistently brought higher prices on the Los Angeles market than any other peach ripening at the same time. In 1951 the Federal-State Market News Service for June 7 shows that Robin brought the highest prices of any variety on the Los Angeles market-27c to $28 \mathrm{c}$ per pound. On the same day all other varieties ranged downward to as low as $9 c$ per pound. Throughout the entire 1951 season this price differential prevailed, just as it has for the past several seasons. No wonder we think Robin is the commercial peach to plant for high profit. Ripens late May, early June. Plant Pat. No. 529.

$2020-\$ 2.25$ each, 10 for $\$ 20.00,50$ or more, $\$ 1.60$ each.
Meadow Lark The Earliest High-Quality Yellow Peach Many people like jellow-fleshed peaches best, and the first yellow peaches of the season taste doubly good. That is why this new Armstrong peach is so valuable for it is the first good yellow-fleshed peach to ripen in Southern California. Meadow Lark is a beautiful yellow medium size peach with a bright red blush covering more than half of the fruit. It is semi-freestone, and the juicy yellow flesh is sweet and pleasantly flavored.

The tree of Meadow Lark is almost certain to produce a big crop of fruit every year in Southern California (and anywhere else in the state). The trees usually start bearing the second year after planting, but some years, particularly in light soils, Meadow Lark may produce in its first and second crops some rough malformed fruit. Mature trees have never been known to produce anything but high quality fruit. In the Los Angeles wholesale market Meadow Lark has brought as high as $27 \mathrm{c}$ per pound while other kinds were selling at from $5 c$ to $15 c$ per pound. lts high color and high quality at such an early season are irresistible. It is probably the most dependable peach of all for immediate coastal districts. Ripens late June. Plant Pat. No. 528 . $2000-\$ 2.25$ each, 10 for $\$ 20.00,50$ or more $\$ 1.60$ each.

Meadow Lark, the earliest high-quality yellow peach to ripen

\section{Ripening Calendar for Armstrong Peaches}

The Armstrong peach varieties offered on these two pages can provide you with the finest peaches that it is possible to grow in California from as early as May until as late as October. Not only is the fruit extremely high in quality, but the trees will give you fruit every year-and plenty of it! They have been hybridized, selected and introduced to give you the best in peach satisfaction.

Robin-Late May, early June

Meadow Lark-June

Reduing-Late June, early July

Altair-Early August

Flamingo-August

Golden Blusb-August

Curlew-September, October

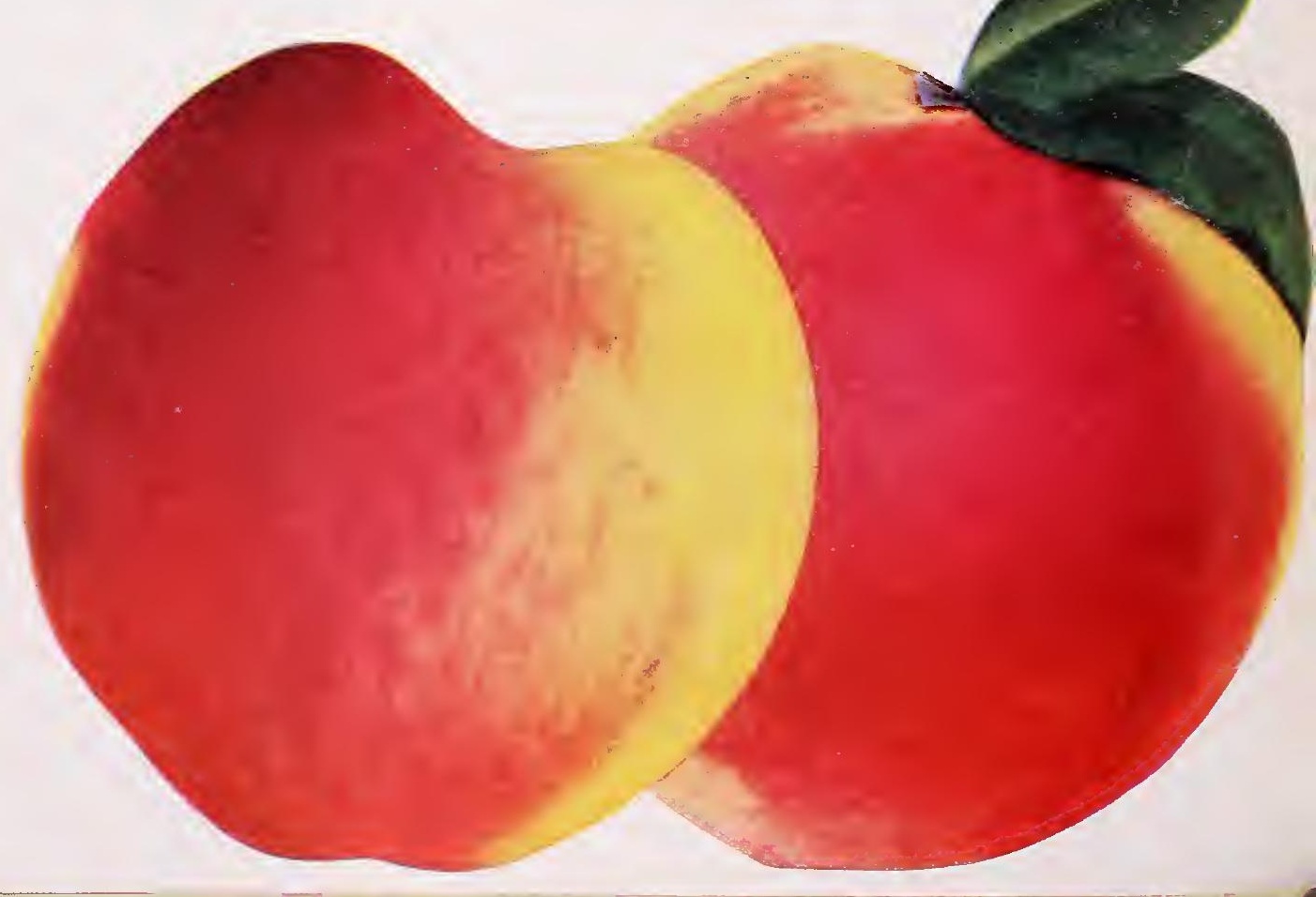




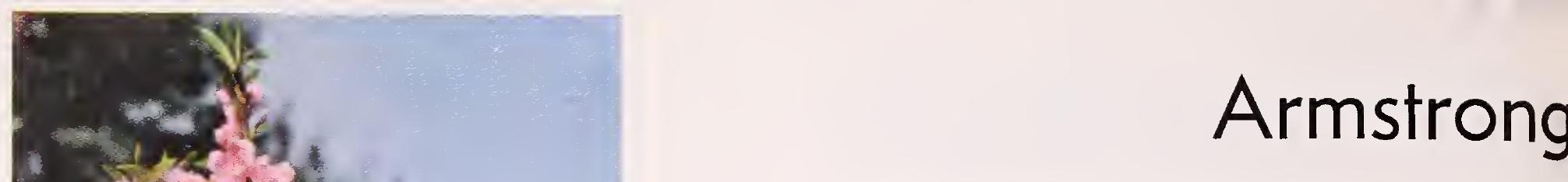

\section{The Newest Armstrong Introduction}

\section{Fruit and Flowers, Too!}

\section{Altair}

We were very proud to offer planters for the first time last year, this newest Armstrong introduction. It is a peach which our hybridists have been working on for a long time, and one which we have been waiting and hoping for. Everyone appreciates those harbingers of spring, the flowering peaches when they unfold their billowing masses of lovely bloom. Until now, though, you have had to plant both a flowering peach and a fruiting peach to enjoy the best qualities of each. With the advent of the new Armstrong peach, Altair, you can enjoy the tree in the early spring when blanketed with exceedingly beautiful big double pink flowers - just as showy as any flowering peach you have ever seen, but that's not all-in August you can pick a big crop of delicious whitefleshed peaches, as well. Altair is a fruiting-flowering peach which you will enjoy not just once a year, but twice.

In the latter part of February the tree literally becomes a mass of the big double pink blooms which make a magnificent display of color in the garden and provide armful after armful of flowering sprays for the house. Since a fruiting peach ought to be pruned to get good-sized fruit anyway, cutting bloom sprays from the tree will help to accomplish this purpose. In August the tree will be loaded with handsome, juicy, white-fleshed, freestone peaches.

This unusual new variery was hybridized right here in Southern California particularly for Southern California conditions. Like the other Armstrong varieties, it is almost certain to have a big crop every year in this area. Originated at the Armstrong Nurseries by H. C. Swim. Plant Pat. No. 1022. $1950-\$ 2.50$ each, 10 for $\$ 22.50$.

\section{Standard Varieties}

Altair, our first fruiting-flowering peach. Fruit shown here considerably reduced in size.

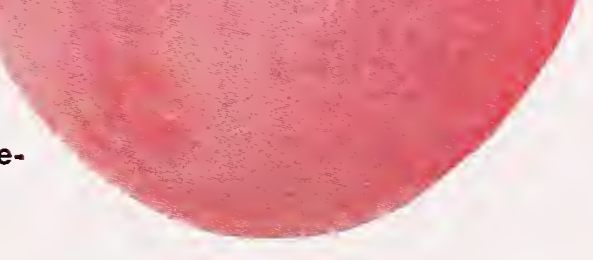

Mr. John A. Armstrong, Jr. admires the crop on a young tree of Redwing in our trial orchard. Redwing is fully described on page 75

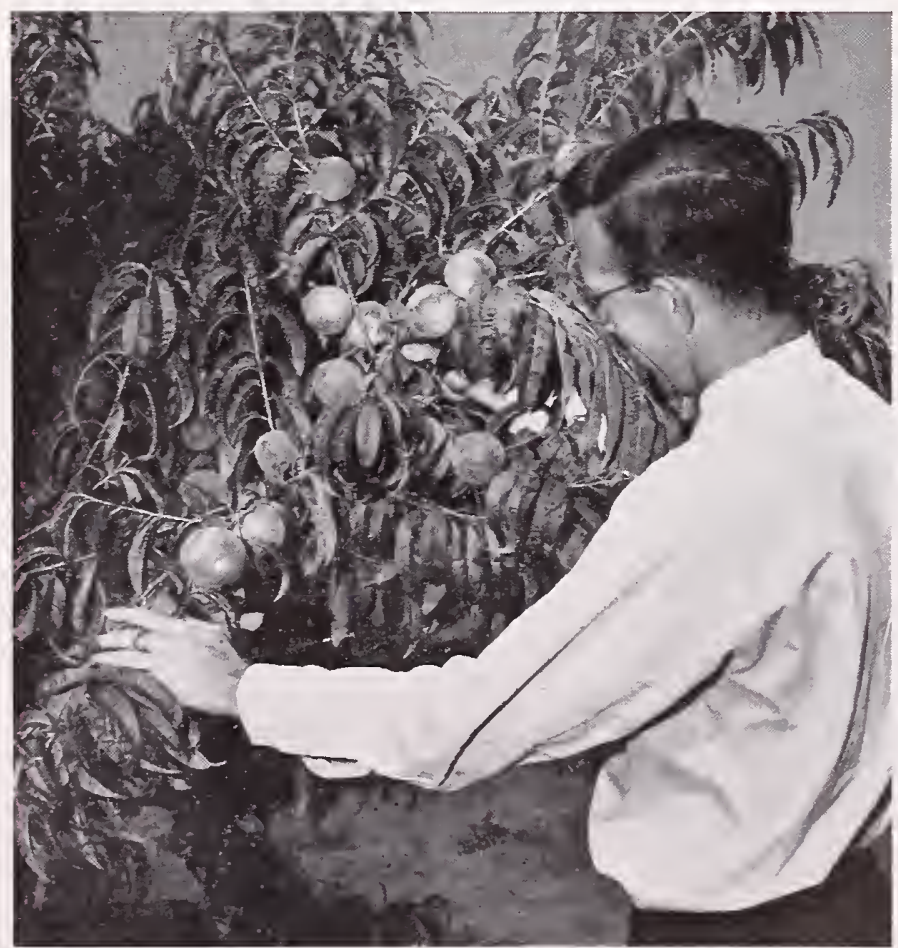

The special Armstrong peaches described above and on the two preceding pages were hybridized and selected especially for Southern California conditions, but the varieties listed on these two pages including the cling stones have been found the best from among standard peach varieties for mild-wintered areas. All of these varieties, as well as the special Armstrong introductions, will do well in the rest of California and other Southwestern states or in other peach growing areas.

All Armstrong peach trees are budded on special resistant rootstock which makes for more vigorous and longer-lived trees.

\section{Sizes}

All peach trees offered in this catalog are 1-year trees which caliper $3 / 8$-inch or more. Most of them will caliper $1 / 2$-inch or more and will be 4 to 6 feet. However, in most cases trees will be properly cut back for planting before shipment.

\section{Babcock}

The Babcock was introduced chiefly because of its habit of bearing a heavy crop of fruit every year in mild-wintered regions regardless of weather conditions. The fruit is small to medium in size, beautiful in appearance, with a bright red fuzzless cheek. The juicy, sweet, white flesh is of excellent quality. It sets such heavy crops that the fruit must be thinned heavily to get size. Babcock grows and bears well over a wide area, including such dissimilar locations as Arizona and Hawaii. Early July.

$1955-\$ 1.75$ each, 10 for $\$ 15.50,50$ or more $\$ 1.25$ each.

\section{Early Elberta}

This early ripening yellow peach is one of the most dependable and popular varieries now planted in California, and both for home and market we can recommend it highly. It does well and consistently produces good crops almost everywhere in the Southwestern States from the coastal area to the inland valleys. The medium size fruit is almost round, yellowish, with a rich red cheek and a beautiful orangepink cast. The flesh is of very high quality, almost clear yellow, rich and juicy. This early-ripening Peach is exceedingly firm, hence it ships very well and is good for canning, too. Middle July.

$1965-\$ 1.75$ each, 10 for $\$ 15.50,50$ or more $\$ 1.25$ each.

The nectarines are simply smootb-skinned peacbes, but in ricbness of flav or they are unexcelled. Be sure to see the neu Armstrong Nectarine introductions for Soutbern California on page 78. 


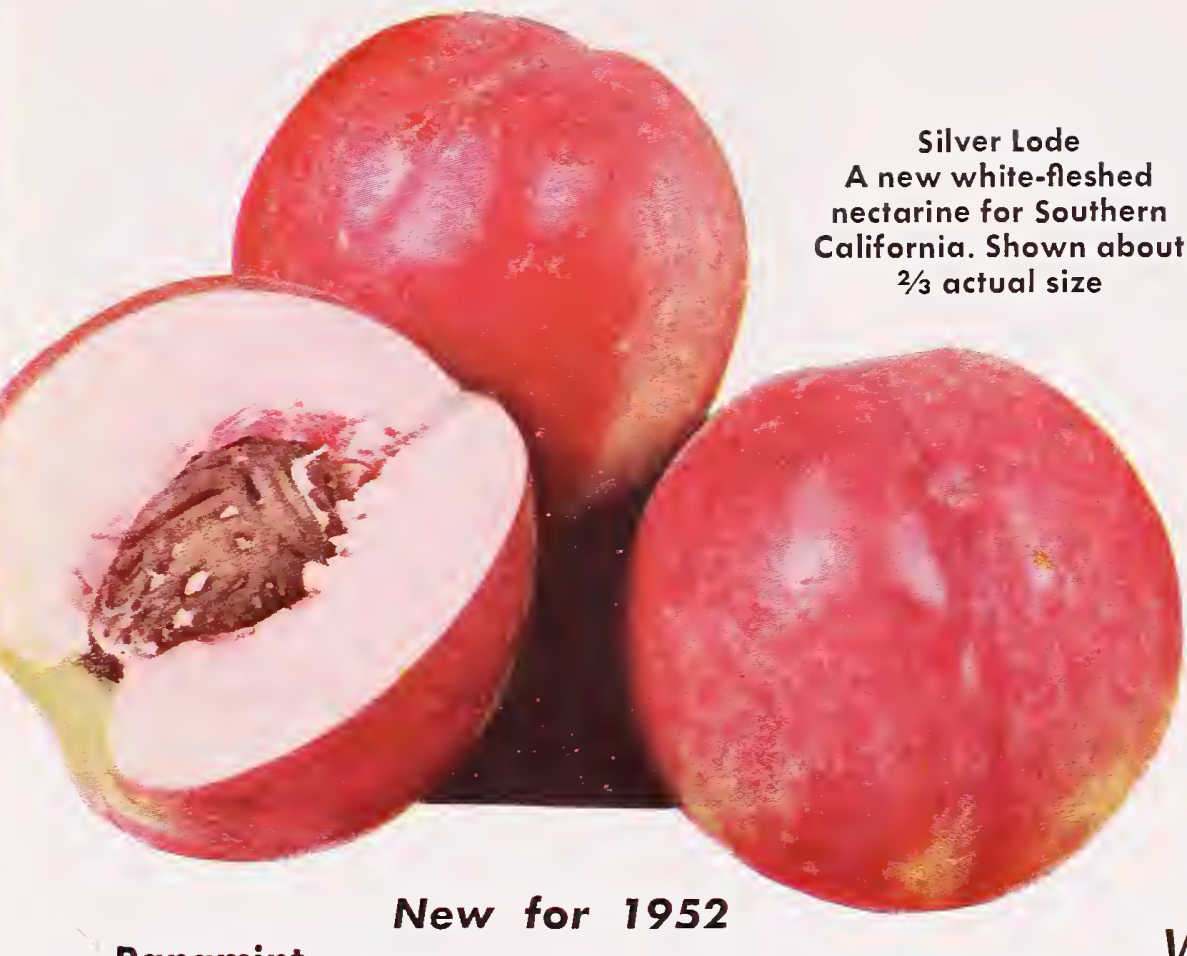

From Armstrong Research

New-Better

Kinds

"Fruit of the Gods" is a fitting name for the nectarines. Reading up the scale of fine flavor and deliciousness, they begin where peaches end. More than a decade ago the Armstrong hybridists tackled the problem of developing new varieties which would make it possible to grow and enjoy these delicious fruits in Southern California. It is with a great deal of pride that we can now offer Southern California planters Pioneer, Silver Lode, and our newest introduction, Panamint. All three kinds will give you plenty of fruit and they will do it every year. These are the very first nectarines of which that can be said.

\section{Panamint}

A most welcome addition to the series of nectarine varieties developed by Armstrong hybridists is this new variety which will be offered for the first time in the 1951-52 season. lt's a "find" as rich as any oldtime prospector ever found in the Panamint Mountains.

While selected especially for Southern California it has now been sufficiently tested to establish the fact that it will be a heavy bearer almost anywhere in California, and should be an outstanding variety for the San Joaquin and Sacramento Valleys, and even many of the Southern States-in fact, any place where mild winters make it impossible to grow ordinary nectarine varieties successfully.

The big round fruits are exceedingly handsome in color, with a rich deep red overlaid on orange. The juicy yet firm flesh is golden-orange in color and loaded with a sweet yet exhilarating flavor. Even though the skin is quite thin, it is tough enough so that the fruits are easy to handle and will keep extremely well. In Southern California. Panamint ripens in early July, usually about two weeks earlier than its sister variety in the orange-fleshed kinds, Pioneer. In nearly all areas you can expect a big crop of delicious fruit from either kind, but if you live near the coast, Panamint is the best one to plant. Originated in the Armstrong Nurseries by H. C. Swim. Plant Pat. Appl. for. $1927-\$ 2.75$ each, 10 for $\$ 24.00,50$ or more, $\$ 1.95$ each.

\section{White-Fleshed $\mathcal{E}$ Delicious}

\section{Silver Lode}

This new red-cheeked, white-fleshed nectarine is another of the rewards for the many years spent in hrbridizing nectarines to get better varieties for warm wintered areas. Just as Pioneer and Panamint are great advances in yellow-fleshed nectarines for these areas, Silver Lode is just as great an improvement in white-fleshed kinds.

Silver Lode is a beautiful big fruit with a creamy white skin heavily overlaid with scarlet. The juicy melting white flesh is laden with the richest kind of nectarine flavor. To say the variety ripens early is putting it mildly, because in our experience it ripens weeks earlier than any other nectarine now in commerce. In Southern California it usually ripens a week or so earlier than the new Panamint, and from two to three weeks earlier than Pioneer.

Because of its early ripening, beautiful appearance, and delicious flavor, Silver Lode is going to make nectarines a favorite fruit with many people who have never paid much attention to them before. Like its companion varieties, Silver Lode can be counted upon to bear a big crop every year in Southern California. Originated in the Armstrong Nurseries by H. C. Swim. Plant Pat. No. 1023.

$1933-\$ 2.50$ each, 10 for $\$ 22.00,50$ ar more, $\$ 1.75$ each.

\section{Pioneer}

The enthusiastic way in which this new nectarine has been accepted by our friends and customers since its introduction three years ago is ample reward for the 10 years spent in its development. Most everyone is fond of nectarines (if they aren't it's just because they haven't tasted them), and the big red and yellow fruits of Pioneer are unbelievably good. The underlying color is a deep yet bright orange, with a heavy overlay of rich dark red in varying tones. Even though it is good to look at, the ultimate purpose of a nectarine is to be eaten, and the juicy orange-colored flesh of Pioneer has a delicious flavor all its own. We can best describe it by saying that every time you eat one, it will taste like another. Even the crisp tender skin is sweet.

With Pioneer you will not have to hope for a crop-you'll get it every year without fail in the interior valleys of Southern California and even fairly good crops along the coast. Its big, showy, pink flowers make it a beautiful ornamental as well as a source of some of the most delicious fruit you have ever tasted. Ripens late July. Originated in the Armstrong Nurseries by H. C. Swim. Plant Pat. No. 787.

$1930-\$ 2.50$ each, 10 for $\$ 22.00$ 50 or more, $\$ 1.75$ each.

\section{Panamint Nectarine-shown here about $1 / 2$ actual size}

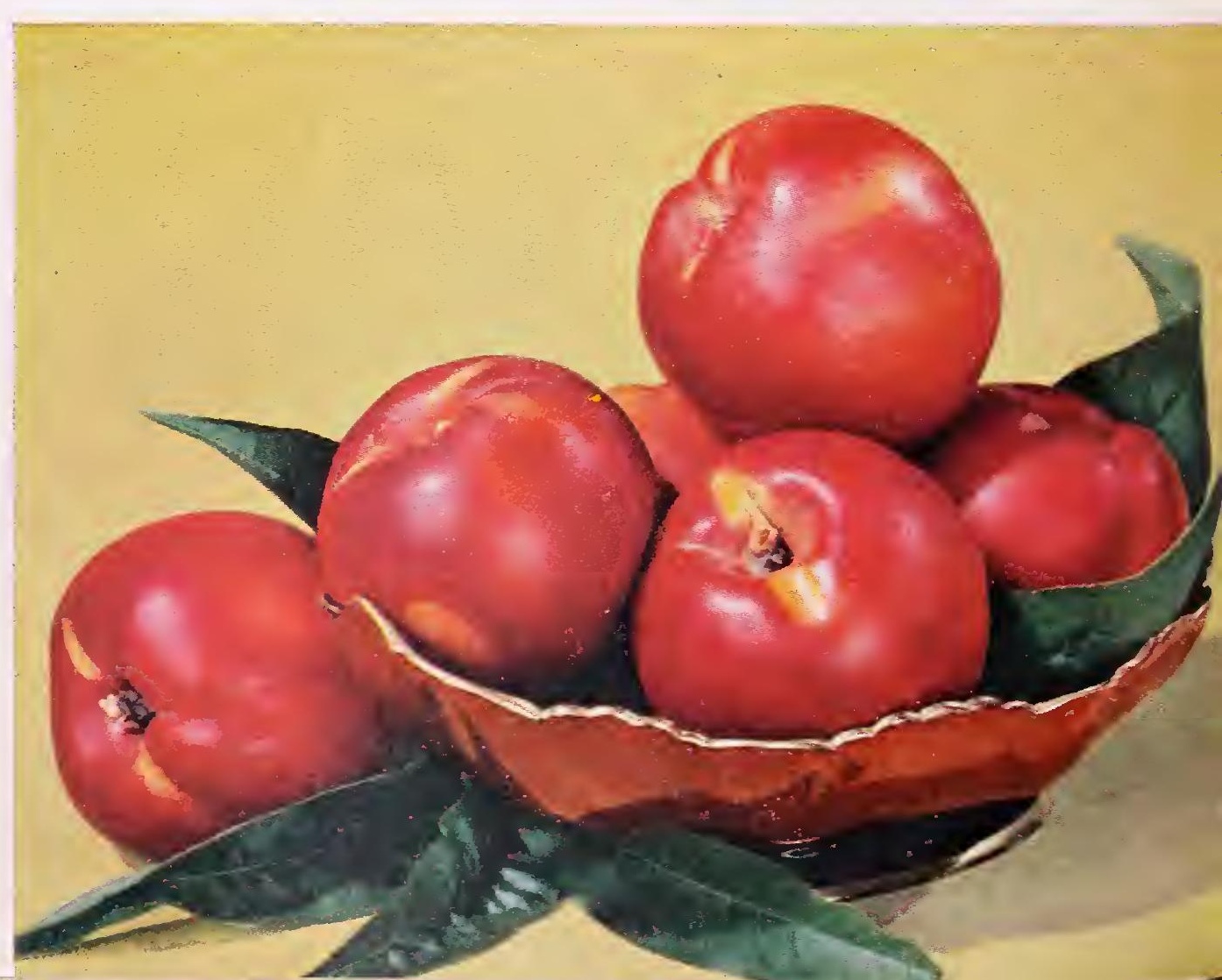




\section{Good Looks}

You have probably heard it said that the nectarine is a cross between a peach and a plum-not so-they're simply fuzzless peaches with a heavenly flavor. The tree of both the peach and the nectarine look alike, but there the similarities end, for the fruit has qualities you will find in no peach. The skin of nectarines is absolutely smooth and very highly colored. You can polish them as you would an apple and they'll shine like a mirror. With their tantalizing aromatic fragrance and the rich color of the glossy skin, there are few fruits as desirable for a fruit bowl.

\section{Fine Flavor}

When it comes to flavor-well, nectarines have a richness and sprightliness to their flavor which surpasses that of any peach. You have a real treat in store for you when you try canned nectarines, too.

\section{Juicy Big Summer E Fall Pears}

All pears bear best in the higher altitudes and northern sections where winters are colder and more prolonged. However, most of the varieties we list will give you delicious pears to enjoy right from your own trees here in Southern California. Better crops will result if two or more varieties are planted together for cross-pollination.

Prices on Pears: 1-year trees, caliper $3 / 8$ inch up, $\$ 2.00$ each, 10 for $\$ 17.50$.

\section{Large-Fruited Winter Nelis}

This is a large-fruited type of the famous Winter Nelis which has been thoroughly tested in Southern California. It bears exceedingly heavy crops of fine, big, russeted pears with a ruddy pink cheek which keep for a long time after picking. The flavor is rich, aromatic and delectable. You will find that the tree will bear heavy crops almost anywhere in California, but it should be planted with one of the other varieties listed here for cross-pollination. October and November. 2080.

\section{Bartlett}

The pear most widely planted in California, with big, golden-yellow, rosy cheeked fruit that is richly flavored, buttery and melting. Heavier production will result if one of the other pear varieties listed here is planted with it for cross-pollination. August. 2070

\section{Winter Bartlett}

A late fall ripening pear similar to Bartlett in shape and color and with the same exquisite flavor, although it is smaller and ripens much later. This variety will probably bear the heaviest and most regular crops of any pear in Southern California, even in the low altitude and desert regions. The fruit keeps remarkably well and you can keep it in a cool place for weeks after picking. November-December. 2090.

\section{Dwarf Pears}

If your space is limited but you would like to have a lot of fine pears for your family to eat, you'll want to plant these dwarf trees that we have grown especially for such siruations. The trees seldom become more than about 8 feet high, begin to bear almost immediately after you plant them, and bear immense crops. Dwarf pears will bear almost anywhere in Southern California or elsewhere and require little care.

Prices on Dwarf Pears: 1-year, double budded on two understocks, caliper $3 / 8$ inch up,

$\$ 3.50$ each, 10 for $\$ 31.50$

\section{Dwarf Bartlett}

It is the world's finest pear. What more can we say? 2095.

\section{Dwarf Beurre d'Anjou}

Planting it with another variety will give you bigger crops on both. 2100.

\section{Dwarf Large-Fruited Winter Nelis}

The new giant strain of this fine old fall ripening pear. 2110

\section{Dwarf Winter Bartlett}

Bears heavy crops in Southern California most consistently. These tasty late ripening long keeping pears please everyone. 2115.

\section{Gorham}

This variety which we are now offering for the first time promises to be exceptionally good in Southern California. In size, shape and color the famous Bartlett. The tender white flesh is both buttery and juicy with a rich flavor and spicy aroma, fully equal to Bartlett - and that is saying a great deal. Our own tests have proved that Gorham will bear consistently good crops in Southern California and a pear so high in quality which will do that is bound Bartlett but the fruit will keep a month longer. 2072.

\section{Beurre d'Anjou}

Large, yellow fruit marked with russet and crimson, fine for eating or market. Flesh is tender, sweet and juicy. A good pollinizer for all other pear varieties. 2075
Bartlett Pear-the standard by which all other pears are judged. Often much larger than this 


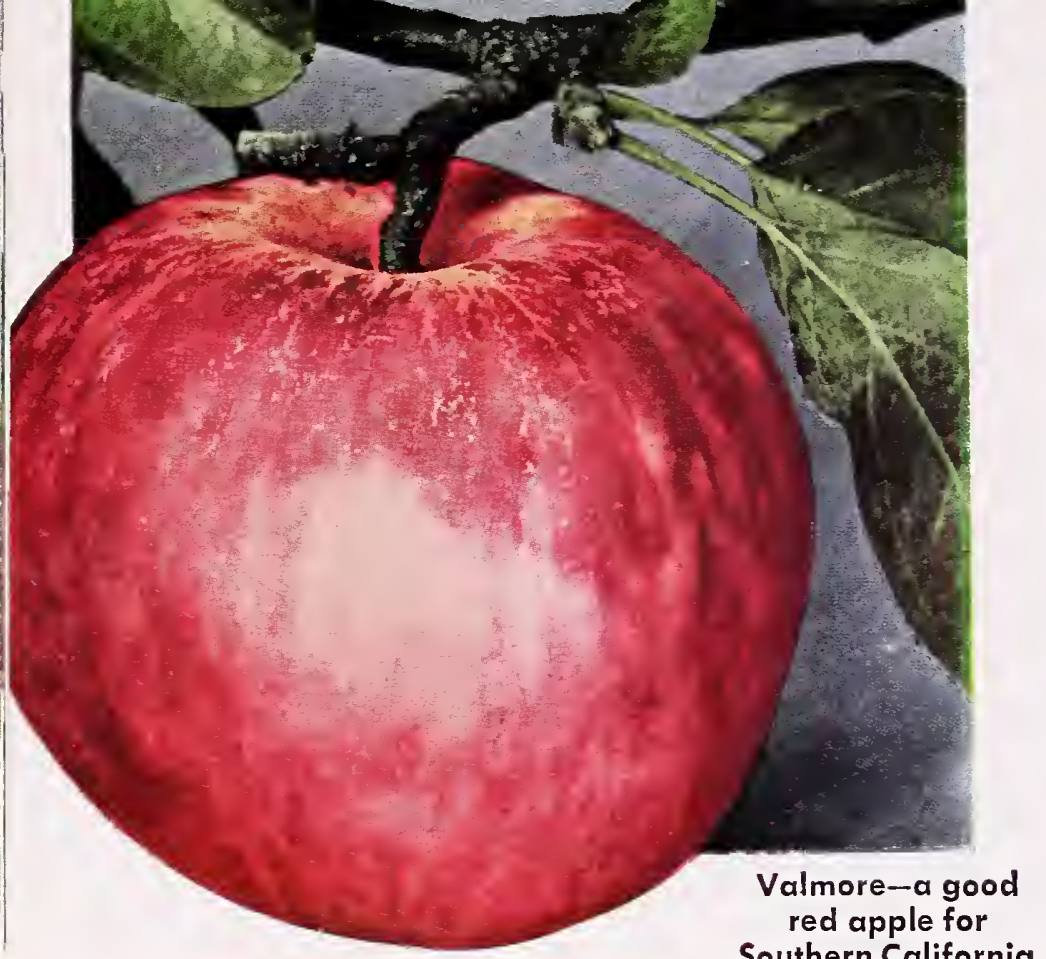

Southern California

\section{Armstrong Apples}

All of the apple varieties described on this page will produce larger crops in sections where winters are colder and more prolonged. However, most of them will do quite well in the lower altitudes of Southern California. Beverly Hills, Valmore, and the new Pettingill are particularly good in this respect. With all apples, larger crops will result if two or more kinds are planted nearby for cross-pollination.

All apples: 1-year trees, caliper $3 / 8$ inch and up. Write for special prices on large quantifies.

\section{Beverly Hills}

An apple that is very well adapted to our Southern California climate or other mild-wintered sections. It should be, it was originated in West Los Angeles, by Dr. W. H. Chandler of the University of California at Los Angeles. The medium sized fruit is beautifully striped red and yellow and it has an excellent flavor. The variety has not been tried out in other sections of California but we highly recommend it for triai because apples which will consistently bear good crops of fruit in Southern California are scarce. Ripens in August.

$1725-\$ 2.00$ each, $\$ 17.50$ per 10.

\section{Red Gravenstein Ripens Early}

A very famous apple, widely grown in California for the summer market. The large round fruits of greenish yellow are beautifully striped with red, and the flesh is crisp, juicy and delicious. Has very excellent keeping qualities and is the earliest ripening commercial apple. August.

$1740-\$ 2.00$ each, 10 for $\$ 17.50$

\section{Rhode Island Greening Best for Pie or Sauce}

The favorite green apple everywhere. Large, round, yellowish green with juicy mellow flesh. For apple sauce and apple pie, it is unexcelled. October. $1745-\$ 2.00$ each, $\$ 17.50$ per 10 .

\section{Winter Banana}

Large, clear, wax-yellow apples with a delicate pink blush. The flesh is mellow and the flavor is even more than what the enticing aroma promises it will be. Dependable in all districts, with a crop every year. August.

$1765-\$ 2.00$ each, $\$ 17.50$ per 10.

\section{A New Heavy-Bearing Apple}

\section{Pettingill}

Here is a truly Southern California apple, originated at Seal Beach, and it seems to do exceedingly well in other parts of the Southland from the coast to the inland valleys. The fruit is very large, rounded and beautifully colored, predominantly deep red with scattered flecks and stripes of deep yellow. The flesh is crisp, juicy, and sub-acid in flavor. If you like apples with a little nip to them, you'll enjoy eating this one out of hand, and, of course, it is marvelous for sauce or pies. Fine appearance, excellent quality and the ability to bear consistently, will make this a very popular apple for Southern California planters. Patent rights reserved.

$1737-\$ 2.50$ each, 10 for $\$ 22.00$

\section{Yellow Bellflower}

Nothing has ever replaced it as a standard market variety in California. An excellent apple for eating and particularly fine for cooking. The fruit is oblong, with a pale waxen yellow skin, beautifully blushed on one cheek, and the flesh is crisp, juicy and well-flavored. Particularly valuable for planting in the coastal valleys.

$1775-\$ 2.00$ each, 10 for $\$ 17.50$

\section{Yellow Delicious}

When you bite through the golden yellow skin deep into the crisp sweet flesh, you quickly discover that this is tops in flavor. Even juicier than the average red Delicious apple, it is sweet and full of apple tang. The fruit is very large and extremely handsome, almost clear waxen yellow in color-the picture on the nex page will give you an idea. Does very well in Southern California, exceeding the red Delicious in this respect. September.

$1780-\$ 2.00$ each, 10 for $\$ 17.50$

The new Pettingill Apple

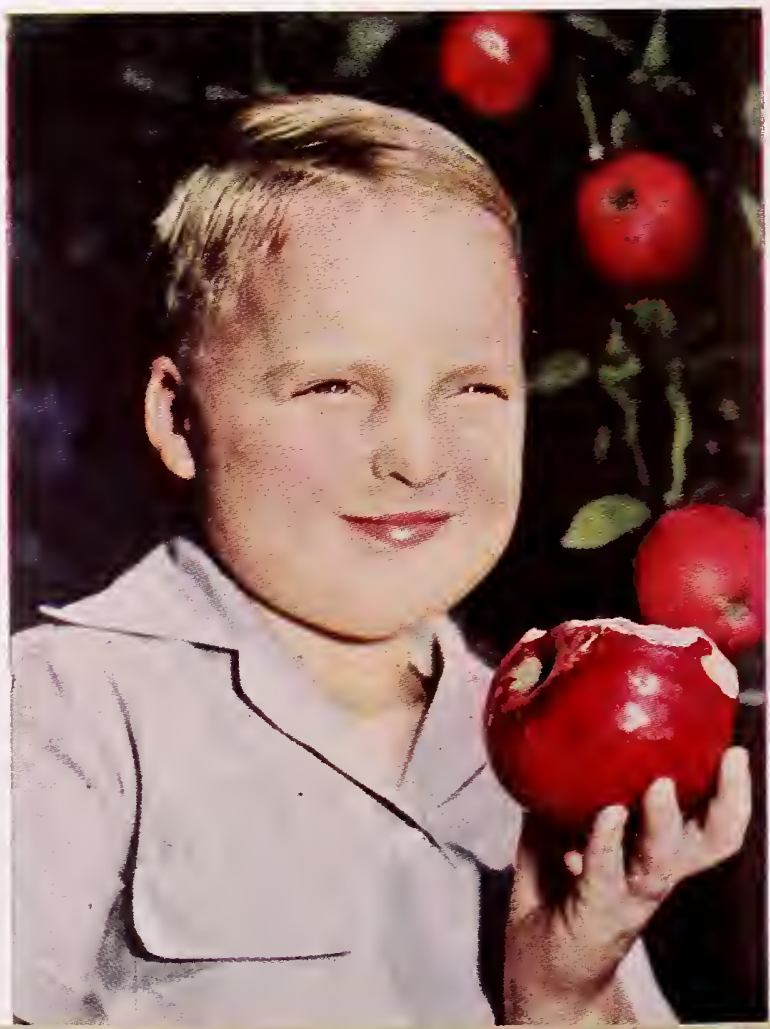




\section{Crabapple}

\section{Transcendent Crabapple}

No other apple will make finer jelly, preserves, or sweet pickles than this variety and no apple will produce such abundant crops consistently, even in Southern California. It never fails to bear plenty of beautiful medium sized fruits, waxy yellow handsomely striped with red. In bloom, it is one of the most beautiful of all apple trees and you'll find the blossoms very fine for cut sprays. The tree with its very handsome dense foliage makes a very good looking small summer shade tree.

$1750-\$ 2.25$ each, $\$ 20.00$ per 10 .

\section{Dwarf Apples}

In most home plantings where space is an important factor, these Dwarf Apple trees are exactly what you need. Successful tests made at one of the leading universities in the country have proved that the three special apple stocks combined in producing these trees will not only cause the trees to be smaller in size, but they will bear heavily, too. The quality of the fruit is fully equal to that grown on a regular tree.

All Dwarf Apple trees, $3 / 8$-inch caliper and up, $\$ 3.50$ each.

$\begin{array}{ll}\text { Beverly Hills } 1785 . & \text { Valmore } 1795 . \\ \text { Delicious } 1790 . & \text { Winter Banana } 1800 . \\ \text { Pettingill } 1792 . & \text { Yellow Delicious } 1805\end{array}$

Yellow Delicious-about actual size

\section{Delectable Figs}

The warm lands to the east of the Mediterranean and California are two of the few parts of the world in which figs attain perfection. The handsome trees with their large abundant foliage seldom fail to set prodigious crops, and most people will agree with us that no fruit is more enjoyable-whether you eat it out of hand, serve it sliced with cream and sugar, or make it into jam.

Prices on all Figs: $3 / 4$-inch caliper and up, $\$ 1.75, \$ 15.50$ per 10 of one variety. Write for special prices on larger quantities.

\section{Pruning}

We recommend pruning fig trees back severely when you plant them. You will find that you get far better and quicker results if you take off at least one-half of the top. We ordinarily do this for you unless instructed otherwise.

\section{Brunswick}

This medium sized, light brown, shortnecked fig is known as Magnolia in Texas. The fine-grained, sweet, brown-amber flesh is delicious. The tree is smaller than many other varieties and will stand more cold than any other fig which we grow. Given a sheltered location, it will grow and bear in Oregon, Washington, New Jersey, Long Island and similar areas. Leave unpruned in California. 1865.

\section{Mission}

Almost everyone is familiar with this famous old variety which can be seen growing and bearing abundantly almost everywhere in California. The fruit is medium to large, mahogany-violet in color, with brownish red flesh. It bears tremendous crops even under adverse conditions and when little water is available. Leave the tree unpruned for greater quantities of fruit. 1875

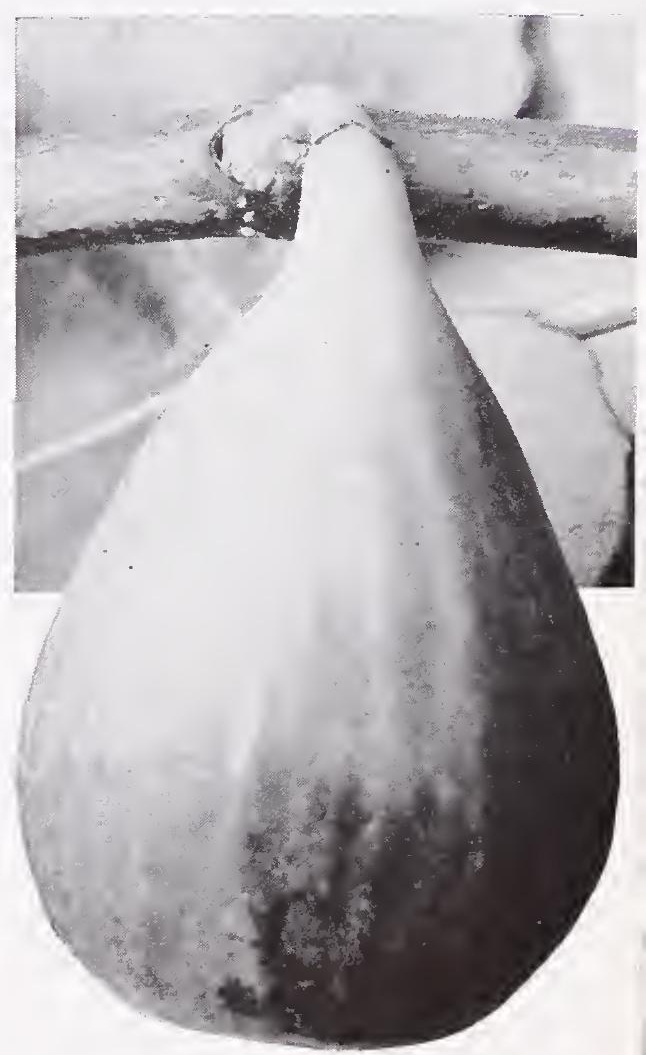

Luscious Brown Turkey figoften larger than this

\section{Kadota}

This is the finest white fig for most of California, and one of the best figs for all purposes, since it will can, dry, pickle or ship fresh with excellent results. The medium size fruit has a smooth, waxy, yellow-white skin and extremely sweet and rich, pale amber flesh. Does best in the warmer interior valleys, producing very heavy crops all through the summer and fall. Heavy winter pruning decreases quantity without increasing size. 1870.

\section{Trojano}

With this variety in your planting you'll be counting the weeks until ripening time when you can enjoy the rich nutty full flavor of these delicious figs. It's a medium-sized coppery black fig, very rare in California and the nearest thing to a Black Kadota which we know. The amber flesh is sweet and delicious, with almost no seeds, and each fruit self-sealed with a drop of honey to keep out insects. Bears enormous crops every year, but leave it unpruned for the greatest yield. 1880.

\section{Brown Turkey}

Just about the finest of all figs for general planting anywhere in California. The fruits are exceedingly large and elongated, rich purplish brown in color, becoming deeper purple as they mature. The rich strawberry-red flesh is fine-grained, sweet and juicy. This is a fig which has been sold under other names as something very "special," but it is just as fine when sold under its own name. Brown Turkey seems to bear equally well whether it be directly on the coast or in the interior or desert valleys, but larger and finer figs will be produced if the trees are heavily pruned in the winter. 1860

\section{White Genoa}

If you live near the sea coast and want a big fine white fig, this is the one for you to plant. You will find it a fine fig in inland areas, the one for you to plant. You will, and has a waxy yellow skin and sweet amber flesh. Heavy pruning will increase the size of the fruit, but you will get lighter crops. 1890. 


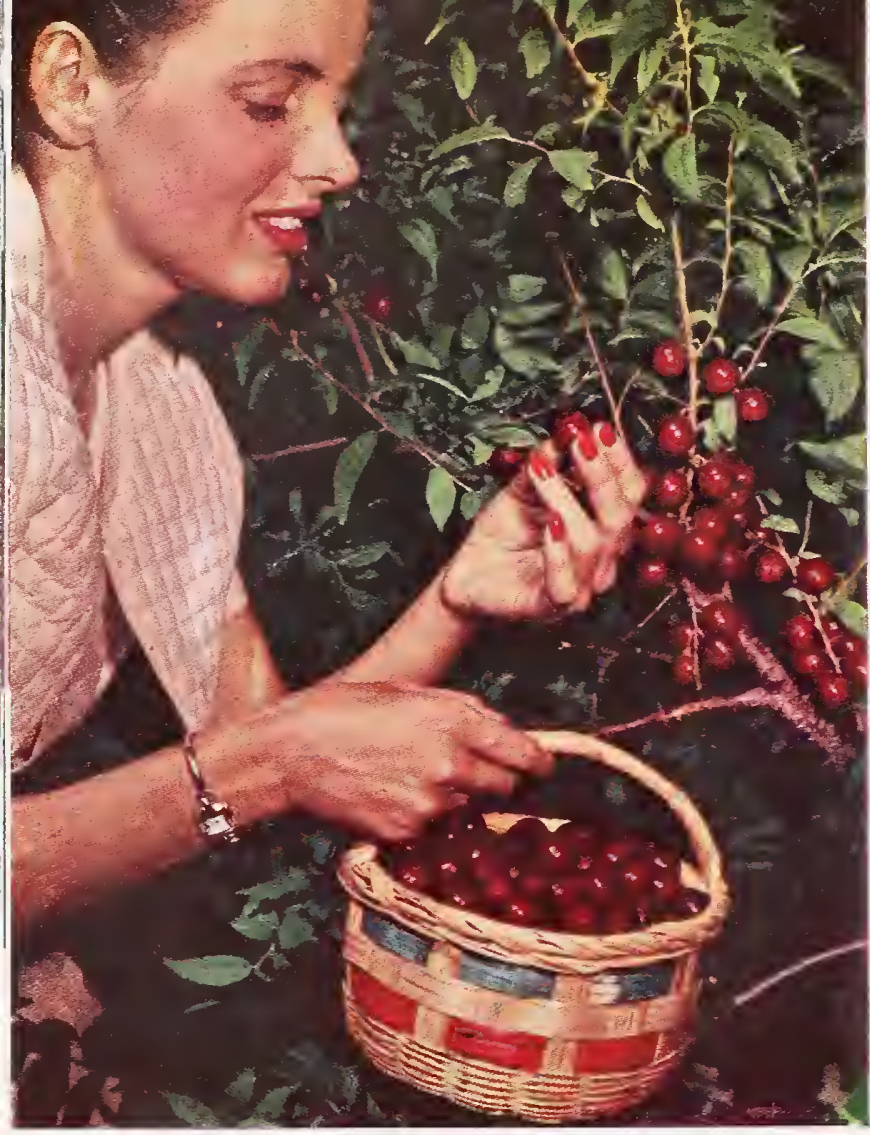

New Korean Cherry No. 20

\section{The Best Cherries}

To some people the so-called "pie" cherries are a little tart for eating fresh but they are the best of all for making cherry pie or for canning. These kinds and the two new Korean Bush Cherries will bear large crops in Southern California and almost everywhere else. The sweet cherries, however, are suited only to the higher altitudes of Southern California (Yucaipa, Beaumont, etc.), but they are entirely satisfactory in the central and northern part of the state. Richmond or Morello will bear if planted alone, but all of the sweet cherries need another variety planted nearby for cross-pollination.

Prices an all Cherries, except Bush Cherries: 1-year, caliper $3 / 8$-inch up, $\$ 2.00$ each, $\$ 17.50$ per 10 af ane variety. Write far special prices an larger quantities.

\section{Sure-to-Bear Kinds}

\section{Richmond}

Excellent early "pie" cherry which will provide large quantities of fruit for fresh cherry pie and for canning. The handsome wine-red fruits have a sprightly aromatic flavor and tender melting flesh. The tree is rather small, round-headed, and does not take up much room on the home place. Especially good for the Southern California coastal and valley regions where sweet cherries do not bear. Will bear heavy crops consistently, no matter where you plant it. Early June. 1850.

\section{Morello}

Beautiful large dark wine-red fruits similar to Richmond but slightly larger, and the fruit ripens 2 weeks later. If you have room for two "pie" cherries, Richmond and Morello make a good combination because the difference in ripening dates means that you will have plenty of cherries all through June. This fine "pie" cherry is the most dependable variety for Southern California coastal and valley districts. It does well anywhere. Ripens in late June. 1845.

\section{New Bush Cherries}

Now you can enjoy cherries grown on your own place here in Southern California, and good ones, too. What's more, you don't have to plant a tree but just a handsomely foliaged deciduous shrub which is very ornamental and small enough to fit into any sunny garden corner. Lovely white cherry blossoms crowd each branch in spring, followed by an unbelievably big crop of delicious large cherries, ripening in July. Judged to be among the best of the many bush cherry types tested by the University of Minnesota, these two kinds have been found to do remarkably well in California, too. Vigorous and easy to grow, cold, wind or heat will not keep them from fruiting regularly.

Either variety below -5 -gal. tins, $\$ 6.00$ each.

\section{Korean Cherry No. 20}

This is the taller growing of the two introductions, about 5 to 6 feet. The fruit is of excellent quality with fine flavor though slightly more acid than the fruit of No. 60. Will bear consistently larger crops if planted with No. 60.6401.

\section{Korean Cherry No. 60}

A smaller bush ( 3 to 4 feet) producing fine large fruit, deep maroon to black when fully ripe, sweet and richly flavored. More like the sweet cherries in color and flavor than No. 20. Will usually bear regular crops if planted alone. 6406.

\section{The Sweet Cherries}

\section{Black Tartarian}

The big, juicy, sweet black beauties ripen early in the season when cherries taste the best. With their rich juicy flesh and attractive purplish-black color they are hard to beat for eating fresh. Like other sweet cherry varieties, Tartarian does not bear in the coastal and valley regions of Southern California but the robust erect tree bears tremendous crops in all cherry-growing areas. Plant Bing with it for pollination. Early June. 1840

\section{Bing}

The fruit is very large, dark red, and of extremely handsome appearance. Since it has the firmest flesh of all cherries, it is marvelous for canning and is the best for shipping. Plant Tartarian with it as a pollinizer. Ripens June. 1835.

\section{Royal Ann}

Everyone enjoys the big pale yellow cherries with the bright red cheek and the sweet, firm flesh. And it's the leading commercial canning cherry, too. Bears tremendous crops in all cherry-growing areas, if planted with Tartarian for a pollinizer. Ripens in late June. 1855.

\section{Sugar-Sweet Prunes}

Prunes are mercly plums with a higher percentage of sugar and California prunes are well known to everyone for their healthful vitamins. But why depend upon dried prunes in the summer when you can enjoy fresh ones which are much more delicious? The fruit is handsome in appearance, and most people do not realize how delicious they are when eaten fresh from the tree, or canned for table use. All prunes bear better if several kinds are planted for cross-pollination.

Prices an Prunes: 1-year trees, 3/8-inch caliper and up, $\$ 1.75$ each, $\$ 15.50$ per 10 af ane variety. Write far special prices an larger quantities.

\section{French Improved}

The standard drying variety which has made California dried prunes famous. Large oval fruits of deep purple, with sweet sugary flesh produced in great quantiries. September. 2185.

\section{Sugar}

Very large, dark purple fruit, the sweetest of all; particularly fine for home planting in Southern California, where the tree is exceedingly productive in all sections. The handsome big fruits are delicious to eat out of hand and are exceptionally fine for canning. July. 2195.

\section{Standard The Most Handsome and Largest Prune}

The big oval fruits are deep purple with a rich blue bloom, and the flesh is amber colored, juicy, and exceptionally sweet. This is the largest and handsomest of all prunes and is ideal for home use or for the fresh fruit market. Bears well everywhere but particularly fine in the valleys of Southern California. French Improved or Sugar should be planted with it as a pollinizer. Ripens in August. 2190. 


\section{Delicious Plums}

Plums do exceptionally well in California and the sweet, deliciously flavored, long-keeping fruit is in demand everywhere. Thanks to a great deal of work by the late Luther Burbank and others, new varieties have been developed which will grow and bear well in nearly every part of the state. With the exception of Climax, all plum varieties will bear normal heavy crops only if certain other varieties are planted nearby as pollinizers. The plum varieties listed below are in their approximate order of ripening.

All plums below, 1-year trees, $3 / 8$-inch caliper and up, $\$ 1.75$ each, $\$ 15.50$ per 10 of one variety; except Maripasa, $\$ 2.00$ each, $\$ 17.50$ per 10 of one variety. Write for special prices an larger quantities.

\section{Bequty}

The large fruit is beautifully colored deep crimson and the ambercrimson flesh is juicy and full-flavored. A never-failing bearer everywhere, and particularly enjoyable because it is almost the first plum to ripen. Plant Climax with it. June. 2130.

\section{Climax}

The very large heart-shaped fruit with a beautiful deep red and yellow color, is one of Luther Burbank's finest introductions. The golden yellow flesh is firm yet richly flavored and juicy. Does not always bear heavy crops in the coastal or other mild wintered areas, but is the one variery on our list which needs no pollinizer. Late June. 2140.

\section{Santa Rosa}

Certainly this is one of the handsomest plums grown in California and one of the most widely planted. The big purplish crimson fruit is covered with an attractive blue bloom and the sweet delicious amber colored flesh is veined with crimson. Tops in quality for market or home use, Santa Rosa bears heavily each year no matter where it is planted. Bears fair crops without a pollinizer, but should be planted with Beauty. Late June. 2170.

\section{Hollywood}

It must have been called Hollywood because of the ultra-modern job of make-up. Everything about it is colorful-the blood-red, juicy, sweet plums, borne early in the season, the purple-red foliage and the cloud of lovely light pink flowers in the spring. It is not only beautiful, but the fruit is delicious to eat, reminding us of an enormous sweet black cherry when fully ripe. Since it is one of the first plums to ripen in the season, its brilliant color and fine flavor are doubly enjoyable. Inca is probably the best pollinizer. Late June. 2145.

\section{Satsuma}

The well-known Japanese Blood Plum, introduced by Luther Burbank, which is so highly prized for preserving. The handsome, almost round fruit is deep red with a heavy lilac bloom. The firm, juicy, well-flavored flesh is a dark purplish red and the pit is small. Best pollinizer is Santa Rosa. July. 2175.

\section{Hollywood Plum-colorful and delicious. Shown about $2 / 3$ normal size}

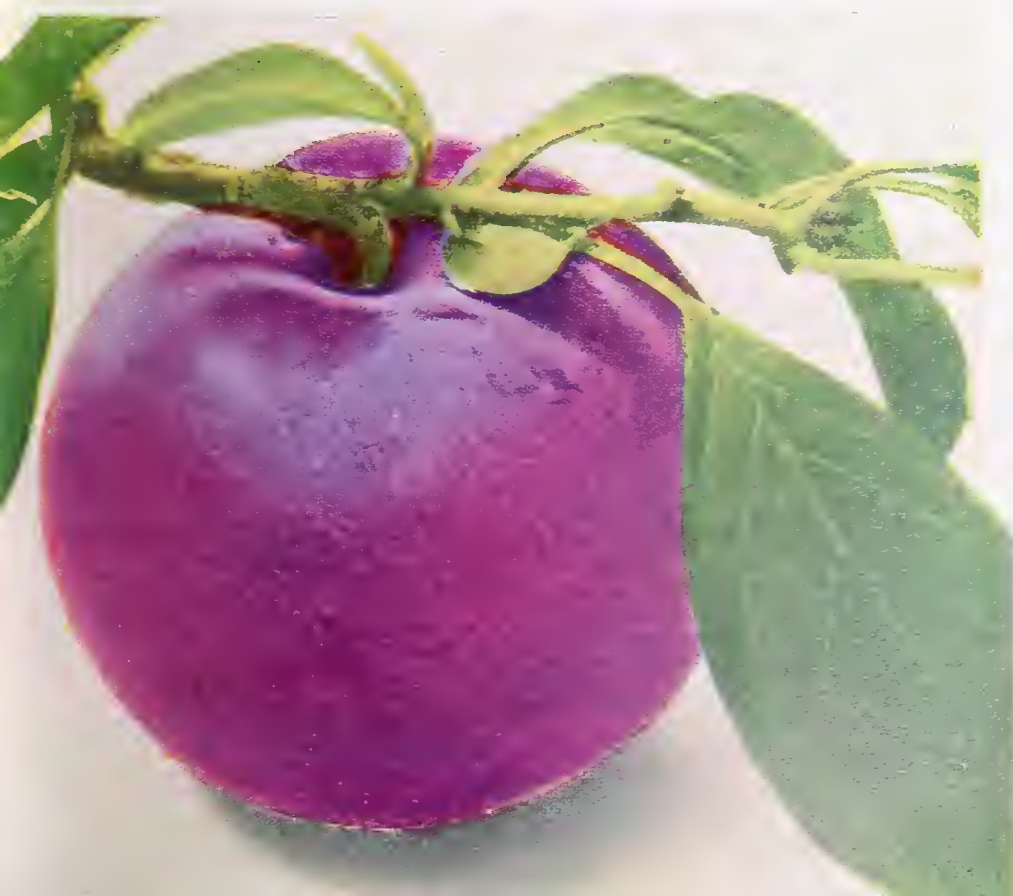

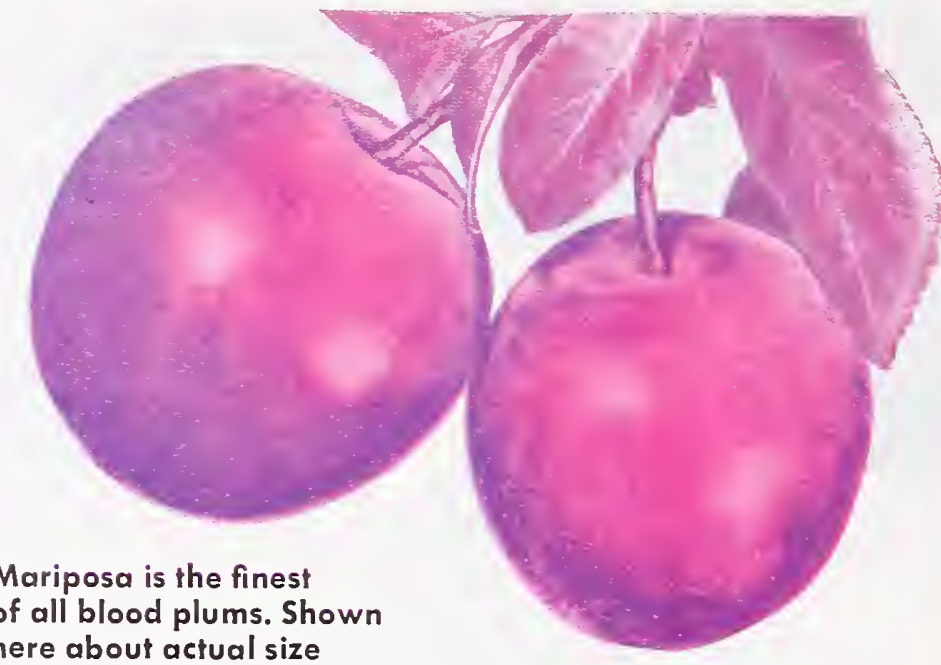

\section{Mariposa The Big Blood Plum}

When it comes to comparative eating qualities, Mariposa stands out as the very best. It is a variety which we introduced a number of years ago, and which is now proving extremely popular in such widely scattered areas as the Pacific Northwest, Colorado, and Texas, and, of course, all parts of California. The gigantic purple-red fruits are over laid with a glowing lilac bloom, and the blood-red flesh has a honeylike sweetness, abundant juice, and a surpassing flavor which it is impossible to describe in words. The skin, while tender in the eating, is quite thick and the flesh is firm so that the plum keeps remarkably well. There is no bitterness to the skin or at the pit-just rich sweet goodness through and through. Mariposa should have a tree of Sat suma, Late Satsuma or Santa Rosa planted near it as a pollinizer. Late July. Plant Pat. No. 111. 2160.

Warning! Inferior blood plums have been sold as Mariposa. Look for the Patent tag bearing this name and Plant Pat. No. 111. Unles it does carry such a tag, it is not genuine Mariposa.

\section{Inca}

Among the yellow plums, this is one of the finest for eating. Its firm, sweet, golden flesh is very juicy and richly flavored. Every year the tree bears a heavy crop. For a midseason yellow-fleshed plum, we would pick it to plant over all other plums of its type lt is one of the late Luther Burbank's originations which was lost for a number of years. Plant Santa Rosa with it as a pollinizer. Late July. 2150.

\section{Late Satsuma}

Everyone likes those delicious sweet Satsumas with the blood-red flesh but they are all gone long before September. Now we have discovered a late ripening Satsuma which makes it possible to enjoy those delicious plums in September when other plums are scarce Quite profitable as a late plum for market and certainly fine for canning. Mariposa is a good pollinizer and it will in turn pollinate Mariposa in the colder areas. 2155.

\section{Becky Smith}

This is not only one of the most beautiful plums you can grow, but it is the very latest to ripen. After all others are gone you can pick big, round, bright red fruits with crisp sweet amber flesh. They are marvelous for eating, good for canning and ship exceptionally well. Best pollinizer, Climax. Late September. 2135.

All of the pollinizers which u'e bave recommended for specific varieties have been very carefully cbecked and will do the job best under normal conditions. However, they are not infallible since the blooming season of both tarieties may not always orerlap because of unusual climatic conditions or otber factors.

\section{Pay Us a Visit}

We know that a personal chat with one of our salesmen can help you immensely with any planting problem that you may have. There are Armstrong salesyards in Ontario, North Hollywood, Culver City, Long Beach and San Marino, and in each one you will find a staff of highly trained nurserymen to serve you. Not only will they be able to give you valuable advice in the selection of varieties, but they will also give you some helpful suggestions which will enable you to grow your selections more successfully. 


\section{Deciduous Fruit Trees}

As a group, the fruiting varieties listed on this page are ideally suited for home planting. All are generally small in size and in addition, the jujube, pomegranate, and persimmons are extremely ornamental.

\section{Chinese Jujubes}

Often the first year after planting, this small deciduous tree will start bearing and each year will produce enormous crops of small dark-brown fruits. They are sweet and crisp when eaten fresh, make excellent jam, but are most of ten made into delicious candied fruits. The tree grows anywhere with ease but bears best in the warmer interior valleys. The tree is exceedingly ornamental and hardy. The fruit ripens September and October.

Price on Jujubes: 1 -year trees, caliper $3 / 8$ inch up, $\$ 3.75$ each, $\$ 32.50$ per 10 .

\section{Lang}

The fruit is quite large, $11 / 2$ to 2 inches long, pear-shaped, as shown in the photograph at the left. Lang fruits abundantly and very often you can pick fruit the first year after planting. 1910.

\section{Li}

A selected variety which bears the largest fruit of all. Often it is 2 inches or more in diameter, round in shape. The flesh is deliciously sweet and crisp, and the pit very small. Makes a marvelous candied fruit. 1915.

\section{Quince}

The quinces are a great source of pectin and nothing excels them for making jellies and jams when used alone or in combination with other fruits. When cooked, the flesh becomes a beautiful dark red. The trees are easy to grow and will thrive and bear well almost anywhere.

1 -year trees, caliper $3 / 8$ inch up, $\$ 2.25$ each, 10 for $\$ 20.00$.

\section{Pineapple}

A round, short-necked, golden yellow fruit with a flavor and aroma suggestive of pineapples. October. 2200.

\section{Smyrna}

Extremely large fruits, and the trees bear enormous crops. Nothing is more delightful than the fragrance of these fruits, either fresh or in your favorite preserves. October. 2205.

\section{Big colorful Hachiya Persimmons, shown here about $1 / 2$ actual size}

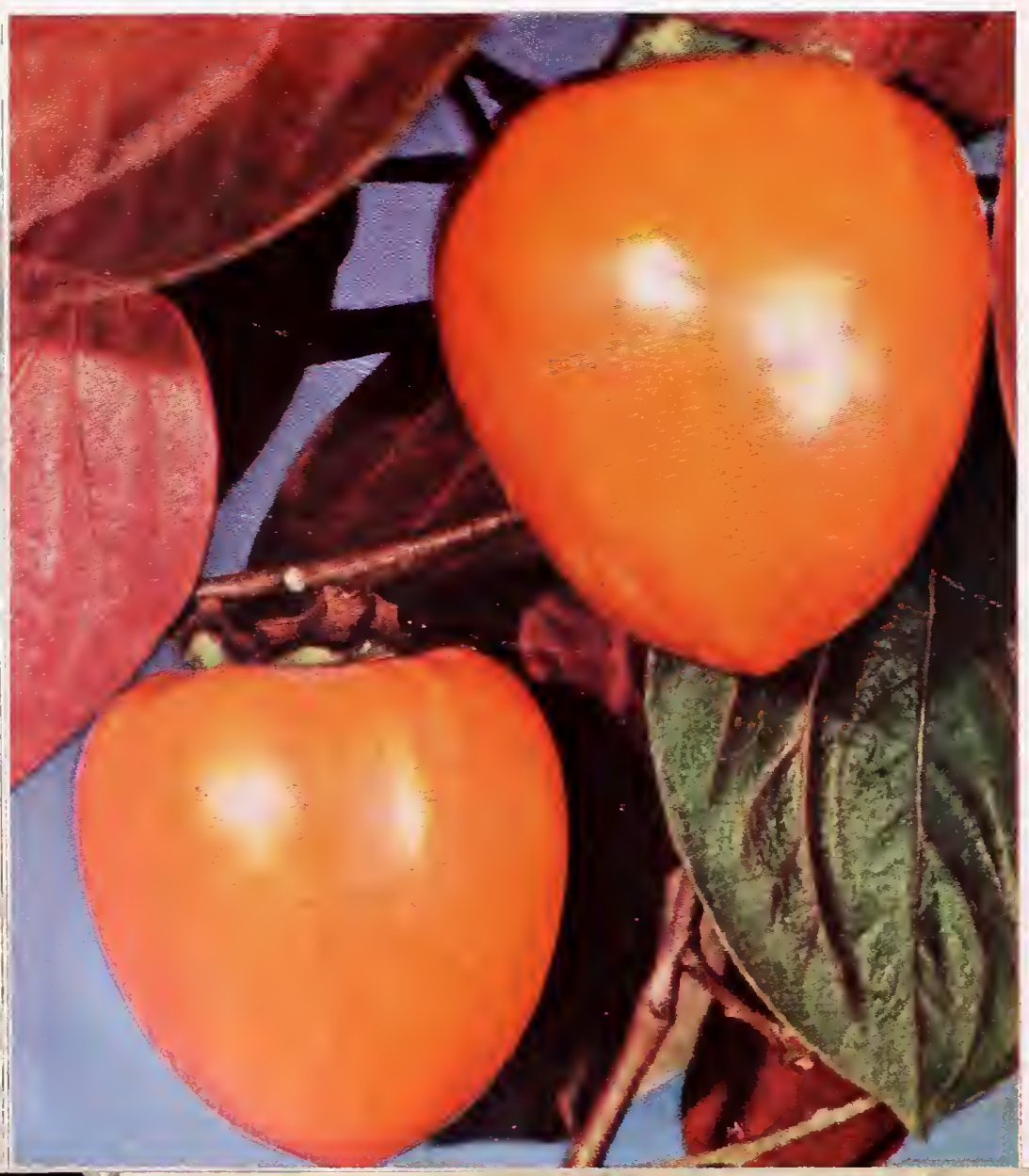

\section{Pomegranate}

Of all fruit trees, pomegranates are one of the most ornamental. They quickly grow into a large 8-foot bush covered with glossy light-green and bronze foliage, and they thrive anywhere from the sea coast to the hottest desert valleys. No other fruit tree produces blooms as spectacular or long lasting as the huge bright orange-red carnation-like flowers. Right at Thanksgiving time, the bush is loaded with big, shiny, crimson-cheeked fruits.

\section{Wonderful}

The best pomegranate variety with very large, bright crimson colored fruits having a juicy flesh, rich garnet in color.

$2180-\$ 1.75$ each, $\$ 15.50$ per 10.

\section{Persimmon}

In the late fall, and particularly at Thanksgiving and Christmas time, the persimmon is very welcome whether you prefer to eat them out of hand, use them in salads, or whether you enjoy (as most everyone does) a delightful persimmon pudding. Persimmon trees are very ornamental because the huge leaves turn to bright reds, bronzes and browns in the fall, just when the tree is hanging full of the brightly colored orange-red fruit. Price on all persimmon trees: $\$ 3.25$ each, $\$ 30.00$ per 10 .

\section{Hachiya}

The best known of all persimmons is this large conical fruit of bright orange red, with its sweet, rich and mellow flesh. No fruit is more handsome than the highly colored, polished beauties, even more striking than the photograph at the left shows them to be. Don't attempt to eat them until they are fully ripe because you'll find them astringent and puckery. When soft and fully ripe, you will find the fruit as sweet and delectable as anything you have ever tasted. 2125.

\section{Fuyu}

Here is a persimmon which is quite different from all other commonly grown kinds in that it is never astringent or puckery. Even when fully ripe, the fruit is quite firm and may be eaten just as you would an apple, whenever it is sweet enough. The fruits are extremely large, flat rather than elongated, but they have the same brilliant orange-red color which makes all persimmons so attractive. The trees of this variety bear much younger than those of most persimmons. 2120 .

\section{For Growing Information}

To get maximum production from your fruit trees every grower should have a source of information on general culture, pruning, and pest control at his fingertips. We stock a number of books dealing with the proper care of fruiting trees and ornamentals, as well. You will find them at any of our five salesyards.

If you have a problem which is peculiar to your location, we suggest that you contact your nearest County Agricultural Extension Agent. Generally you will find him well posted on local conditions and better able to help you than anyone else. 


\section{Armstrong Nut Trees}

Thomas Black Walnut has all the flavor of the Eastern Black Walnut but is easy to crack

\section{California Walnuts}

The walnut is one of California's more familiar fruit and shade tree combinations. It grows vigorously and bears heavily everywhere in California, except in the high mountains and the desert areas. They make grand large shade trees for the home, but be sure to allow plenty of room for them.

Prices on all Walnuts, except as noted: Trees 6 feet and up $\$ 3.25$ each, $\$ 30.00$ per 10 of ane variety. Write far special prices an larger quantities.

\section{Eureka}

Very large, elongated nuts, heavy and well sealed, with cream-colored, plump, waxy kernels. A better quality nut than Placentia and more resistant to heat and frost but does not bear as young nor as heavily. 2745.

\section{Franquette}

Because of its lateness in blooming, its hardiness and dense foliage, this French variety is favored in colder sections. The nut is large, elongated, smooth and tightly sealed, with the meat of very high quality. 2750.

\section{Payne}

A very popular commercial walnut in the valleys of California because of the extremely early and heavy crops borne by the young trees and because of its hardiness. Exceptionally high quality. 2755.

\section{Placentia}

Generally regarded as the best walnut variety for Southern California. The medium sized nuts have a smooth, thin, strong shell, well filled with light tan meats of fine quality. Bears exceptionally large crops. 2760.

\section{Willson Wonder}

If you are looking for the walnut that bears nuts that are really huge, this is the variety to plant. It is often called the "Jumbo Walnut" because of its enormous size, the nuts often measuring more than 2 inches in diameter. The trees bear young and are very hardy. Although you will find that they provide plenty of nuts for home use, they do not produce as many as the standard commercial varieties.

$2765-\$ 3.75$ each, $\$ 34.00$ per 10.

\section{Papershell Pecans}

Almost anywhere in California, from the coast to the desert, the pecan will become a beautiful large, tall summer shade tree. However, they bear satisfactory crops only in the interior valleys where they have plenty of summer heat and at the same time abundant moisture. The young trees have a very long tap root, with very few feeder roots, and are somewhat slow to start. However, after the first year they grow very rapidly. We prune them severely to aid you in establishing them. Prices on Pecans: 1-year trees, $1 / 2$-inch caliper and up, $\$ 6.00$ each, $\$ 55.00$ per 10.

\section{Mahan Pecan}

Until you squeeze one of the mammoth nuts between your thumb and forefinger and feel the paper-thin shell crack as if it were a peanut, you will never believe that such a pecan existed. The shell is completely filled with a big richly flavored kernel which you can remove all in one piece without the slightest difficulty. Actually, the enormous nuts average $21 / 2$ inches in length and only 31 of them will weigh a pound! The tree makes a magnificently foliaged shade tree and even if you live in an area where you will get only a few of those unbelievable nuts, you will be glad you planted a Mahan. 2730.

\section{Success}

This is the variety which has been most widely planted in California, and the finest and oldest bearing trees are of this variety. The nuts are large, oblong, with a medium thick shell and the kernel has an exceptionally fine flavor. 2740 .

\section{Selected Almonds}

Anyone who has seen almonds in bloom will tell you that they are one of the spring's most beautiful flowering trees. But to get plenty of nuts you must plant the right combinations for successful pollination. Good combinations are Nonpareil and Drake, Nonpareil and Texas, Jordanolo and Ne Plus Ultra, or Texas and Drake.

Price an Almonds: 1 -year trees, caliper $3 / 8$ inch up, $\$ 1.75$ each, $\$ 15.50$ per 10 af ane variety. Write far special prices an larger quantities.

\section{Jordanolo}

We can highly recommend this new variety to Southern California planters. Its extremely heavy bearing habit is in evidence wherever it has been planted in California. A very large, vigorous tree, with heavy, dense foliage, bearing abundant crops of large, long softshelled nuts of a superior quality, shelling out easily. Pollinizer, Ne Plus Ultra. 1705.

\section{Drake}

An extremely prolific and consistent bearer in all almond districts. The nuts are medium in size, almost round, very handsome, with a medium soft sheli, plump and well filled. It blooms late and is good pollinizer for Nonpareil or Texas. 1700.

\section{Nonpareil}

One of the most valuable commercial almonds for California, bearing huge crops of those giant papershell nuts with the big plump kernels--the kind you pay extra for in the market. A beautiful tree, smaller than other almonds, with a semi-weeping habit. Pollinizer, Drake or Texas. 1715.

\section{Ne Plus Ultra}

A valuable variety because of its generally large size and attractive outside appearance. The nuts are large and long with a soft corky shell. Plant with Jordanolo or Nonpareil. 1710.

\section{Texas}

A heavy bearer, it blooms late and ripens after most other almonds. The nuts are small, but the plump round kernels with their fine flavor are in great demand commercially. A good pollinizer for Nonpareil and Drake. 1720.

\section{Thomas Black Walnut}

For exceptional richness of flavor no nut can surpass the famous old Eastern Black Walnut. Most everyone knows how difficult it is to remove the richly flavored kernels from those hard shells. This one is a selected strain with all the delicious rich flavor, but it is comparatively thin-shelled and cracks easily. The tree grows readily almost anywhere in California, becoming a big, beautiful shade tree which regularly produces large quantities of the finest walnuts.

$2775-\$ 3.75$ each, $\$ 34.00$ per 10

The gigantic Mahan Pecan (actual size)

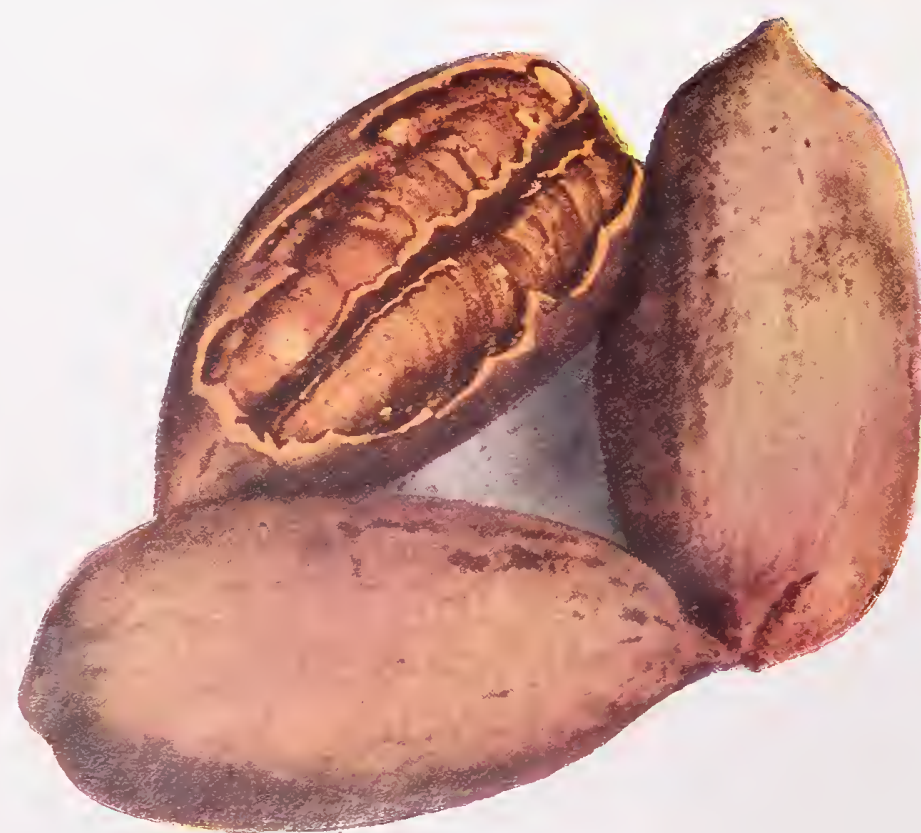




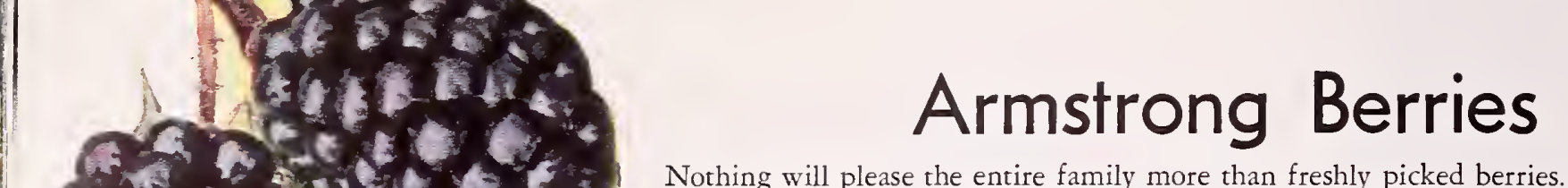

Nothing will please the entire family more than freshly picked berries. These Armstrong tested varieties are easy to grow and will quickly produce heavy crops.

\section{Berry Shipping Calendar}

The black squares under each month indicate when berry plants can be shipped.

Berry and vegetable plants are shipped anywhere in the States at our expense.

\section{Boysenberry}

This huge berry is one of the most popular commercial varieties in California today. Averaging $11 / 2$ to 2 inches in length and 1 inch in diameter, the berries are jet-black, highly flavored, and they pick, keep, and ship in a way which brings delight to the heart of a berry grower. They make the very finest pies, jams and preserves. The boysenberry ripens earlier than other varieties and has proved itself remarkably hardy and adaptable to a wide range of climatic conditions. For home gardens, plant 6 feet by 6 feet. Arrange for irrigation and trellis in the second season. 2440-Transplants, 40c each, $\$ 3.50$ per 10 50 or more, $25 \mathrm{c}$ each.

Gigantic BoysenberryCalifornia's leading berry

\section{Blackberries}

\section{Crandall's Early}

Ripening early in July, it is one of the first blackberries to reach your table. It produces unbelievable numbers of medium size, sweet, firm blackberries with few seeds and almost no core. Plant 5 feet apart in rows 8 feet apart with a trellis or fence for support.

\section{Himalaya}

$2420-30$ c each, $\$ 2.50$ per $10, \$ 20.00$ per 100

The canes often reach 40 feet in one season, and bear enormous crops of excellent, medium sized, juicy black berries. Ripens over a long season from June to late fall. Plant 10 feet apart in rows 8 feet apart on a trellis. $2425-30$ c each, $\$ 2.50$ per $10, \$ 20.00$ per 100 .

\section{Olallie This Looks Good!}

This new early ripening variety promises to be just what everyone has wanted for years-a good new blackberry for Southern California. The fruit is large, juicy, and full of sweet, rich blackberry flavor, yet it is firm so that it picks easily and ships well. Seems to stand heat better than other blackberry varieties, and although very vigorous the bush does not produce the long, heavy canes, as do other kinds, so that the crop is easier to harvest. Trial plantings near Ontario are producing amazingly large crops and the fruit has brought very high prices.

$2427-75$ c each, 10 for $\$ 7.00, \$ 40.00$ per 100

\section{Perfection}

\section{Currant}

A fine quality bright red currant, with a rich yet mild sub-acid flavor. The plants bear heavy crops wherever conditions are suitable, but they do not bear well in the valleys and coastal regions of Southern California. $2450-60$ c each, $\$ 5.50$ per 10

The sensational new Bonanza Raspberry

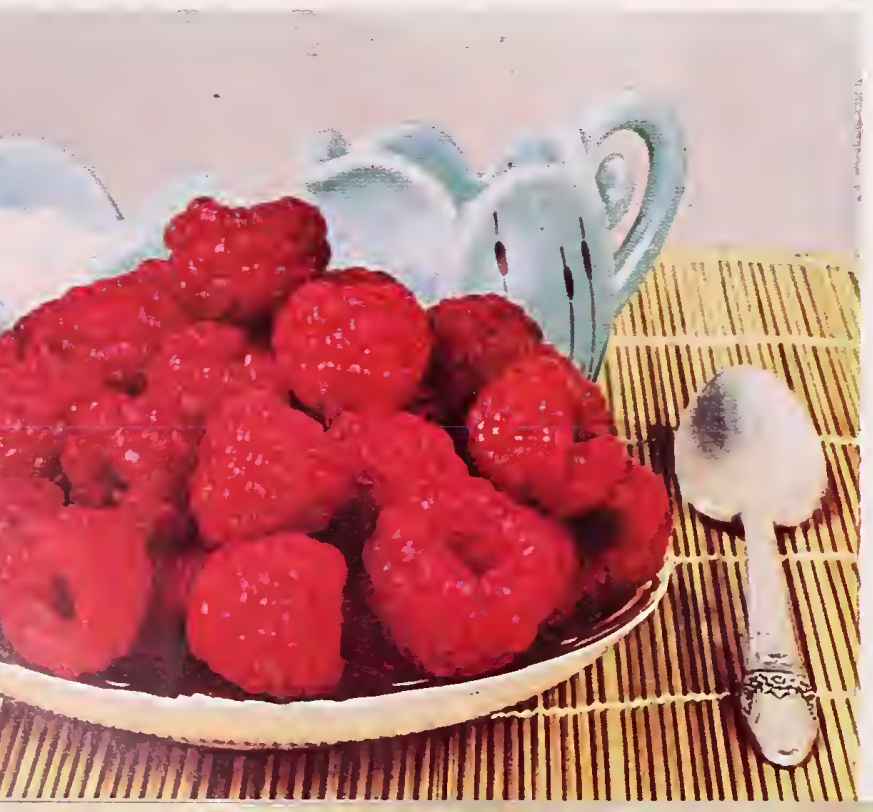

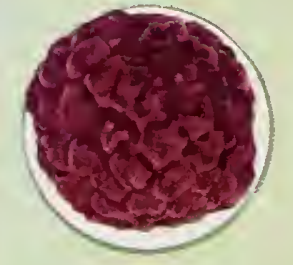

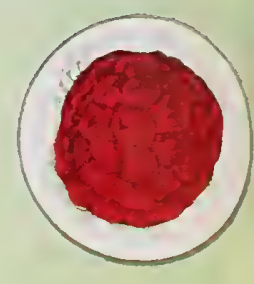

Sodus Purple compared to ordinary red raspberry, each on a 25 c piece

\section{Raspberries}

A never-failing kind is the new Bonanza Berry, a result of Armstrong research. Described on the next page.

\section{Munger}

This is one of the finest Blackcap Raspberries for California, producing great quantities of large jet-black berries, sweet and highly flavored, never dry and seedy. The plants are big and vigorous. $2465-35$ c each, 53.00 per 10,50 or more, $22 \frac{1}{2}$ c each.

\section{Sodus Purple}

Nearly 4 times as large as the ordinary black raspberry, its huge purple berries are juicy, sweet, and filled with good old raspberry flavor. The young plants grow very fast and will of ten fruit the first year if well cared for. $2470-50$ c each, $\$ 4.50$ per $10, \$ 35.00$ per 100

\section{Washington}

We have grown and tested a lot of red raspberry varieties, but next to Bonanza, described on the next page, we think this is one of the very best yet introduced for Southern California. Morning after morning you can pick deliciously flavored garden fresh raspberries with a flavor which you will have to agree is tops. If you want raspberries over a longer season plant Bonanza in addition to Washington, because it will ripen a month earlier.

$2480-35$ c each, $\$ 3.00$ per $10, \$ 22.50$ per 100 .

\section{Thornless Loganberry}

Loganberries have long been a favorite on the Pacific Coast. The dark, wine-red berries have a rich sub-acid flavor and have long been famous for their excellent jam, jellies, and juice. The new Thornless Ioganberry has fruit even better than the old kind and it is a pleasure to pick them from the vigorous, hardy, trailing vines with canes which are absolutely thornless. Plant Pat. No. 82.

$2460-40$ c each, $\$ 3.50$ per 10,50 or more, 25 c each.

\section{Youngberry}

The Youngberry and the Thornless Loganberry are ripe in May, two weeks ahead of Boysenberry. The berries are deep wine color, changing to jet-black, with an exquisite piquant flavor. The seeds are so few and soft that they may be considered as practically seedless, and they make splendid jams and jellies. The plants are extremely vigorous, produce heavily and the berries are remarkable keepers and shippers. Plant on wire trellis 6 to 7 feet apart. 2525-Rooted tips, 30c each, $\$ 2.50$ per 10,50 or more, $20 \mathrm{c}$ each.

\section{Gooseberry}

\section{Oregon Champion}

Large, round, transparent, pale green fruit of excellent quality. Gooseberries are a delight where they can be successfully grown but they do not bear well in the lowlands of Southern California.

$2455-60$ c each, $\$ 5.50$ per 10 . 


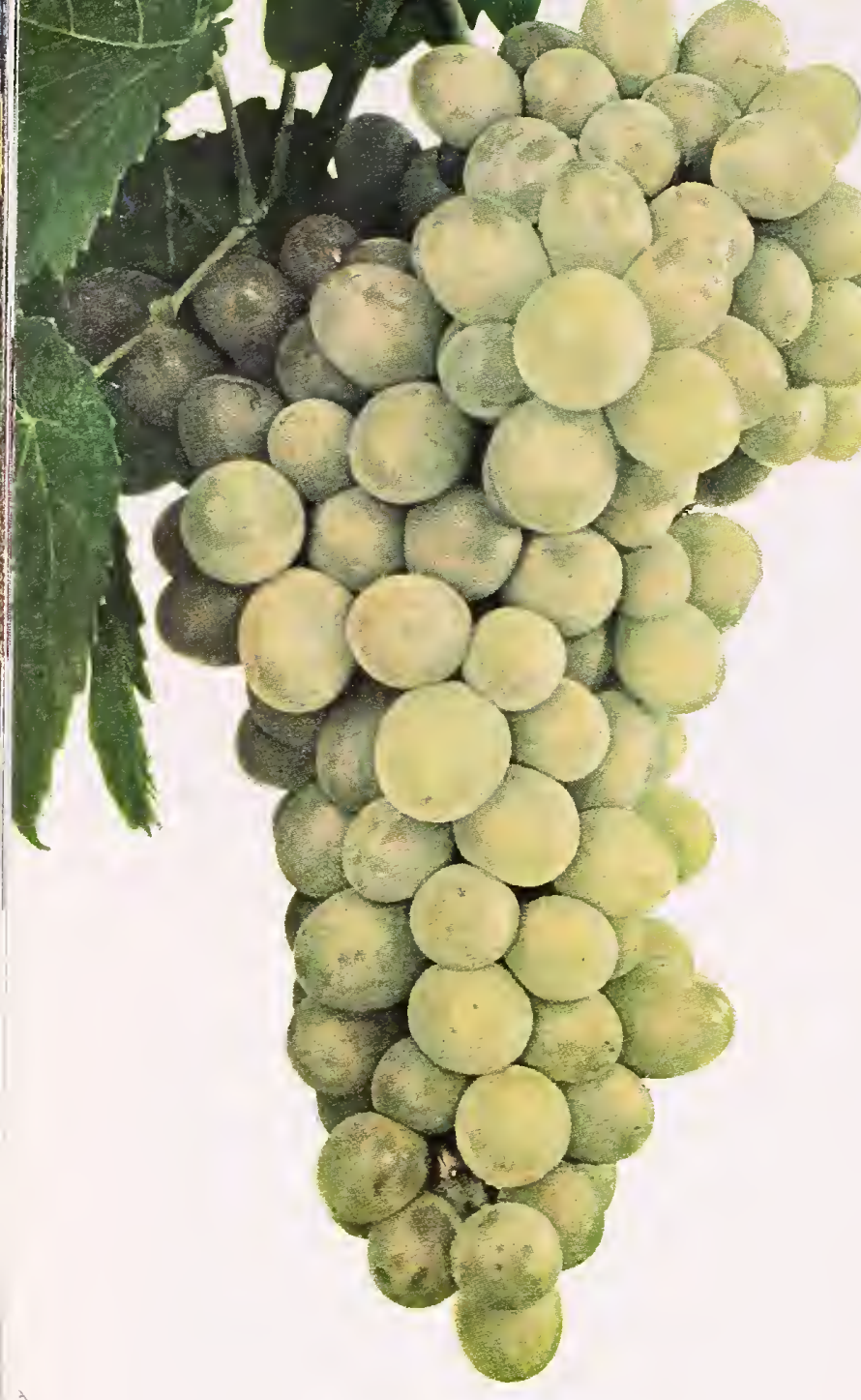

\section{Armstrong}

Some of the world's finest grapes are produced in California, and we are very fortunate in being able to grow the native American or Concord types of the Eastern States as well as the finest kinds from famous OId World vineyards. Grapes from Persia, Turkey, Arabia, France, Italy and Hungary, the choicest of our hardy American grapes, and some fine new recently introduced hybrids are described on these pages. Delight, Perlette and Scarlet, the three splendid new varieties originated by the plant breeders at the University of California, each bring the home planter or the vineyardist desirable new qualities.

\section{When to Plant}

Grapes must be planted when dormant (January to April). With the exception of the big bearing size vines listed on page 90 , they are available for planting only during that time.

\section{Pruning}

At the end of each description we indicate whether the variety should be grown as a bush (pruning canes each year to 2 or 3 bud spurs), or on a trellis or fence (canes to be left 18 inches or longer each winter).

\section{The Outstanding Newer Grapes}

Vineyardists and home planters alike have become more enthusiastic about Delight, Perlette, and Scarlet, 3 new grape varieties originated by the plant breeders of the University of California. Each of them has a distinctive new quality which makes it superior to comparable older kinds.

Prices an Delight, Perlette and Scarlet, $60 \mathrm{c}$ each, $\$ 5.50$ per 10 af ane variety,

50 or mare, same variety, 35 c each.

The new early-ripening seedless grape, Delight

\section{Delight}

Everyone predicts a big future for this new variety both commercially and as a home fruit because of its early ripening, seedlessness, fine keeping, and pronounced yet delicate Muscat flavor. The berries are borne profusely in big loose bunches and they start ripening in late July ahead of Thompson Seedless. They are similar to Thompson in color, though somewhat larger and more crisp. The first truly Muscat-flavored seedless grape ever produced. 2250.

\section{Scarlet}

The jet-black berries are produced in abundance and they yield a delicious bright red juice, sweet and highly flavored. Not only is the juice delicious, but it makes some of the most beautifully colored jellies and jams imaginable. Unlike Delight or Perlette, this variety is not seedless. The fruit hangs on and can be used at any time from the end of August well into October. As an ornamental, the vine is unexcelled. Big and vigorous, it will cover an arbor or trellis quickly. In the fall the foliage turns to bronze and bright red, becoming very attractive indeed. This combination of rapid growth, beautiful appearance, and productiveness is certain to make Scarlet one of the finest of all grape varieties for home planting. Late August. 2320.

\section{Perlette}

The demand for this new seedless variety has skyrocketed because it can be marketed two to three weeks earlier than Thompson Seedless and brings premium prices. The round berries, slightly larger than those of Thompson Seedless, are a beautiful waxy translucent pale green color, with very tender skin and crisp flesh with a mild neutral flavor. The vine is exceedingly vigorous and hangs full of big, foot-long clusters, heavy and compact. Perlette can be pruned as a bush, or left with long canes to cover a fence, trellis, or arbor. The extreme earliness of this variety is proving to be a very valuable characteristic and undoubtedly it is going to be an important commercial variety in California. Late July. 2295.

\section{Early Ripening-High Quality}

\section{Cardinal}

Particularly in the grape districts of the Coachella Valley and Arizona Cardinal is valuable because it ripens long before any other grape of comparable quality. On the market in mid-July it has brought staggering market prices. The fruit is borne in large clusters and the individual berries average nearly an inch in diameter. It is deep red, crisp, juicy, and deliciously flavored with a Muscat tang. Bush type.

$2230-60$ c each, $\$ 5.50$ per 10,50 ar mare, 35c each.

\section{Eastern \& Western Combined}

\section{Golden Muscat}

Whether your taste preference runs to native Concord or European type grapes, you will enjoy this hybrid between the richly flavored Black Muscat and the green American grape-Diamond. It retains the golden green color and slipskin characteristic of Diamond, but it has gained the exquisite flavor of the Muscat. It is a variety which grows vigorously and bears heavily everywhere from the hot inland valleys to the coast. You will get plenty of grapes and good ones, too. Bush or trellis. August.

$2260-60$ c each, $\$ 5.50$ per 10,50 ar mare, 35c each.
The jet-black berries of Scarlet yield richly flavored bright red juice

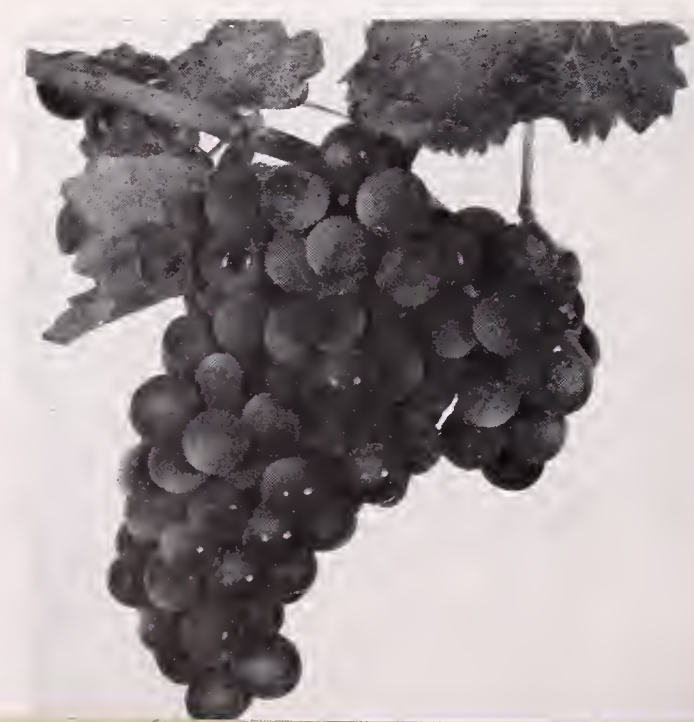




\section{Grapes}

\section{Famous Western Grapes}

All of these so-called California grapes are kinds which have been brought in from the famous vineyards of Europe and Asia. They have been grown in California for many years and have proved themselves in this climate. Most of these kinds are outstanding table grapes which we have especially selected for fine flavor, size and color. Varieties listed in approximate order of ripening.

Prices on all California Grapes below: $35 \mathrm{c}$ each, $\$ 3.00$ per 10 , 50 or more, same variety, $20 \mathrm{c}$ each.

\section{Black Monukka}

This is a seedless black grape from Persia, similar to Thompson Seedless except that the berries are one-third larger and become purplish black when mature. It is a splendid early table grape ripening about 10 days before Thompson, with the very large loose bunches borne in great profusion. A particularly fine trellis type. Early August. 2215.

\section{Thompson Seedless}

The well-known early-ripening seedless grape so popular the country over. It is widely planted commercially, good for raisins and table use. Crops are enormous, with large bunches of delicious, sweet, mildly flavored berries, greenish amber in color. Widely planted, but the heaviest crops are produced in warmer sections. Bush (24-inch canes) or trellis. Early August. 2325.

\section{Black Muscat}

These large, sweet, black grapes have the richest flavor imaginable. $\mathrm{Big}$, crisp, and sweet, they are a favorite with everyone. The vine is a great bearer, too. Bush type. August. 2225.

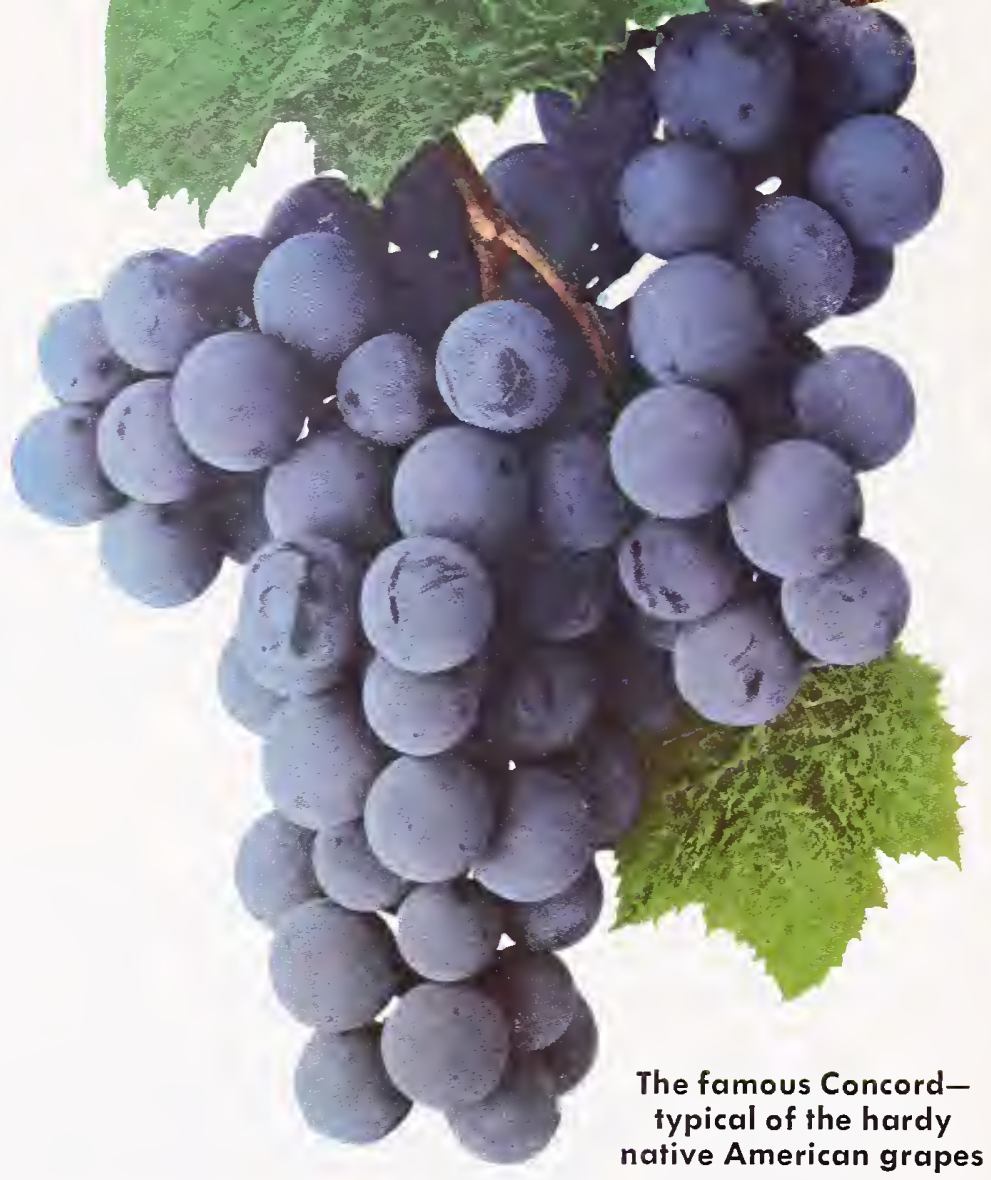

\section{Ribier}

One of the largest and most handsome grapes grown in California. The big, round, almost black berries are very sweet and richly flavored. Ripens early, but the loose medium-sized bunches hang on for many weeks. Bush type. August. 2305.

\section{Malaga}

A leading shipping variety and one of the most popular of table grapes. The bunches are large and loose; berries large, oval, yellowish green with a thick skin and firm, sweet, rich flesh. Bush type. Late August. 2270.

\section{Muscat}

The famous Muscat of Alexandria is one of the most prized varieties grown in California. It is well known for the wine which bears its name, makes the choicest raisins and is prized on the fresh fruit market. Big and crisp, the oval green berries are borne in great profusion and you will enjoy good crops whether you live near the coast or inland. Everywhere the sweet unforgettable rich flavor is acknowledged to be as fine as anything grapedom has to offer. Bush type. September. 2280.

\section{Black Hamburg}

One of the most famous of Old World grapes, and one of the easiest of all varieties to grow. Crisp, sweet and well-flavored, the big, round, coal-black berries are produced freely in huge bunches. Bush o trellis. Late September. 2210

\section{Rish Baba (Lady Finger)}

The long, slender, white-skinned grapes are tender yet crisp and sweet, with a delightful mild flavor. The big bunches are long, too (sometimes a foot or more). The variety keeps exceptionally well and will hang on the vine for a long time. Bush type. Late September. 2310.

\section{Flame Tokay}

One of California's finest late-ripening table grapes and an excellent shipper. The handsome red berries, with a lilac bloom, have firm flesh, are crisp and sweet, and keep for a long time on the bush or after picking. A very heavy and consistent bearer. Bush type. October. 2255.

\section{Hardy American Grapes}

The familiar Concord Grape is a typical example of this type, which is grown extensively in the Eastern and Middle Western States, Sometimes called "slipskins," these varieties are usually stronggrowing and all suitable for arbor or trellis. The type does exceptionally well anywhere on the Pacific Coast, excepting the hottest desert sections. More frequent irrigations in summer are required than for California grapes.

Price on American Grapes: $60 \mathrm{c}$ each, $\$ 5.50$ per 10,50 or more, same variety, 35c each.

\section{Niagara}

This is the standard American green grape. The berries are large, apple yellow, tender, sweet, and juicy. Like others of the so-called Concord types it will grow vigorously and produce abundantly except in the hottest desert sections. August. 2285.

\section{Christmas}

If you have a fence or an arbor that you want to cover quickly and at the same time want a grape that bears fine crops every year, you can find no better variety than this, originated by Luther Burbank. An enormous grower, covering great surfaces, it has fruit similar to Concord in color and flavor, but ripening two months later. One vine will produce five times as much as a Concord Grape. October. 2235.

\section{Concord}

Almost everyone is familiar with this old-time favorite American grape. You have probably drunk its famous unfermented juice, so widely advertised for its healthful qualities. The delicious blue-black grapes are borne profusely in medium-sized bunches, and nothing excels them for grape juice and jelly. The berries have that famous slipskin and rich unforgettable flavor. Ripens large crops in California. August. 2240.

\section{Pierce California Concord}

Similar to Concord, but the berries and bunches are larger and the vine is a stronger grower. It is one of the finest American grapes for California, and if you are going to plant only one black Eastern grape, we suggest this one. August. 2300.
The early ripening Thompson Seedless bears heavy crops like this

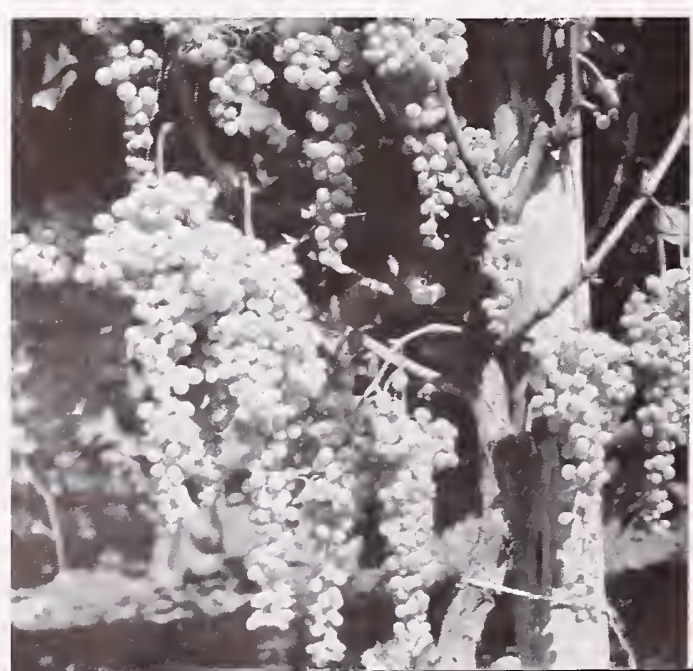




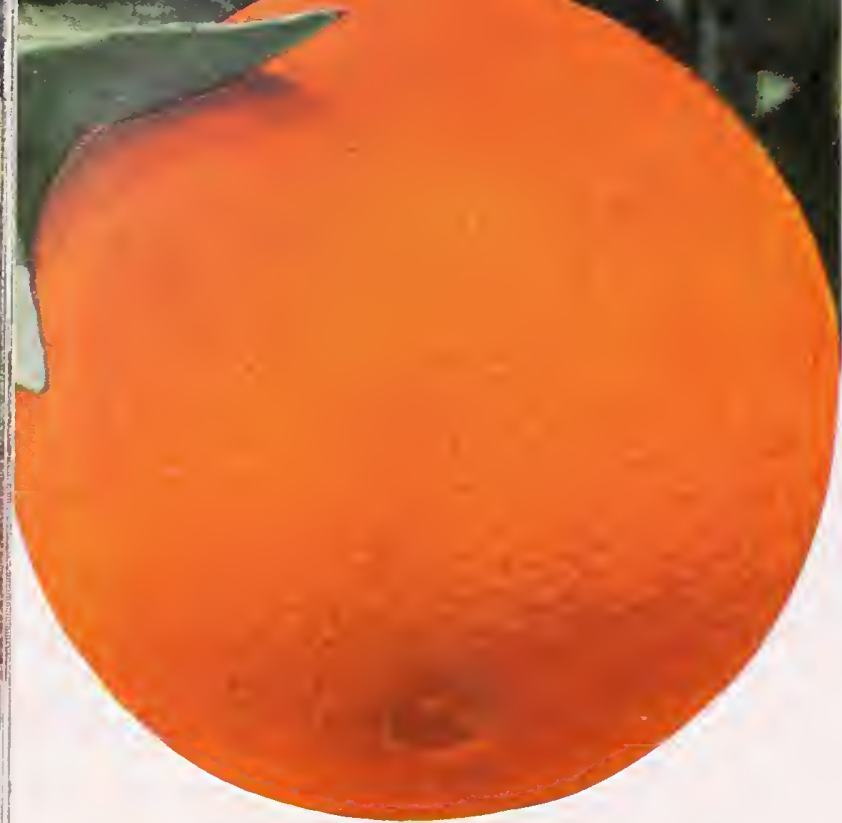

Robertson Navel-the best Navel orange for home planting

\section{Citrus Fruits}

\section{Tangy Tangelos}

Tangelos are a cross between the tangerine and the grapefruit. They are easy to grow, bear heavy crops at an early age, and are just as hardy as oranges. A tree of each variety will give you delicious breakfast fruit or juice over half the year.

\section{Minneola}

One of the rery best for Southern California has proved good in such widely scattered locations as Los Angeles, Riverside, and Coachella Valley. Everywhere the large, glossyskinned, reddish orange fruits are juicy, tender, and of highest quality. Unlike many citrus varieties, Minneola seems to be outstanding under coastal conditions as well as inland. February to May. $\quad 7270-2$-year, caliper $1 / 2$ inch up, $\$ 6.50$ each, $\$ 60.00$ per 10 .

\section{Pearl}

One of the most delightful citrus juice fruits of all. The medium sized, rounded rellow fruits ripen earlier than Sampson or Minneola. Pearl makes a beautiful ornamental tree with long, dark green, willow-like branches. December through March.

$7275-2$-year, caliper $1 / 2$ inch up, $\$ 6.50$ each, 10 for $\$ 60.00$

\section{Sampson}

The golden yellow, glossy-skinned fruits are filled with a delicious orange-red juice. Colors up early in the winter but will become sweeter and better if allowed to stay on the tree until late winter or spring. February to May.

$7280-2$-year, caliper $1 / 2$ inch up, $\$ 6.50$ each, 10 for $\$ 60.00$.

\section{California Oranges the Year 'Round}

\section{Robertson Navel Orange}

This improved winter-ripening orange is our first choice for home planting anywhere in California because of appearance, color, tenderness, flavor, and juiciness. It is equal to the finest Washington Navel, thus it is the best eating orange in the world. You can pick the fruit two to three weeks ahead of the Washington Navel before the heavy winter frosts or you can pick it as needed. The Robertson Navel is exceptionally valuable as a home fruit because of its consistent bearing, its high quality, and the fact that the full grown tree is somewhat smaller than that of Washington Navel. The trees usually start to bear as soon as planted and will continue to produce heavy crops each year. Plant Pat. No. 126

$7240-1-y r$., caliper $1 / 2$ inch up, $\$ 6.00$ each, $\$ 55.00$ per 10 .

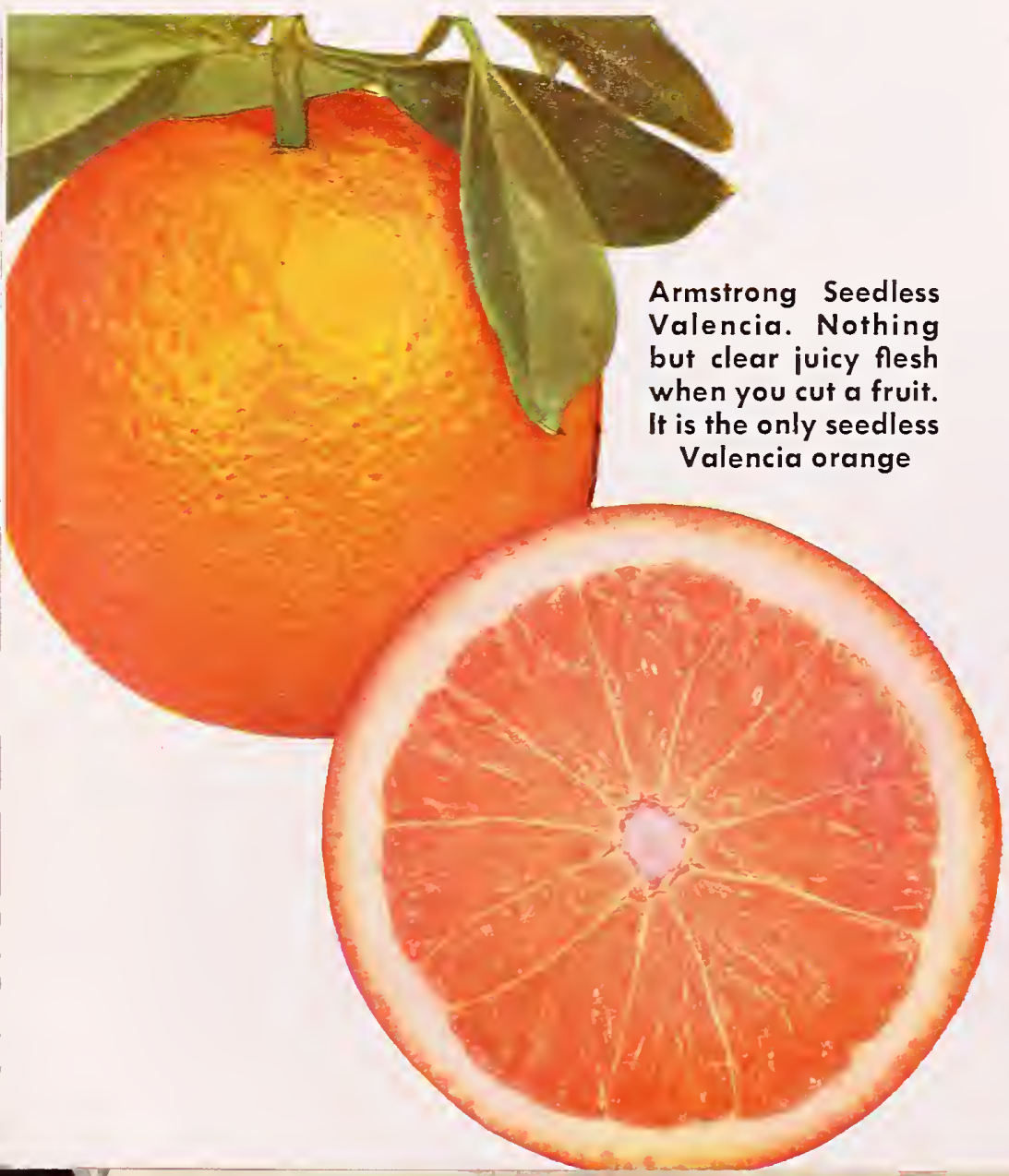

\section{Washington Navel Orange}

The world-famous winter-ripening orange of California. In flavor, juiciness, and general high quality, the large fruit is not excelled by any orher orange. The skin peels off readily and the delicious sections are easily separated. It grows and bears well in all areas suitable for citrus. December to April.

$7265-1-y r .$, caliper $1 / 2$ inch up, $\$ 5.50$ each, $\$ 50.00$ per 10

\section{Summernavel Orange}

California has become famous for oranges because of the quality, fine flavor and juiciness of the Navel. But Navels have been available only in the winter and spring. Now you can enjoy beautiful, large, juicy, full-flavored Navel oranges as good as any you have ever tasted. They ripen in March, are at their best in June and July, will hang on through August. Plant Pat. No. 347.

$7255-1$-yr., caliper $1 / 2$ inch up, $\$ 6.00$ each, $\$ 55.00$ per 10

\section{Armstrong Seedless Valencia}

Wherever oranges are grown, the Valencia is considered to be the finest summer juice orange. Ordinarily the fruit contains from 4 to 8 seeds which must be strained out each time the juice is squeezed. Like all Valencia trees, the Armstrong Seedless Valencia grows rapidly and produces fruit very similar to the ordinary Valencia. If anything, it is possibly finer textured, with less rag, and is a little better in quality. When you have this one in bearing you can throw away your juice strainer. Plant Pat. No. 124.

7235-1-yr., caliper $1 / 2$ inch up, $\$ 6.00$ each, $\$ 55.00$ per 10.

\section{Valencia}

The most popular summer orange the world over is the Valencia. It starts ripening in May and you can pick fresh fruit filled with rich healthful juice almost every day throughout the summer and fall months. The fruit is of medium size, juicy and sweet, with few seeds, and the tree becomes one of the largest of all citrus varieties.

$7260-1-y r$. , caliper $1 / 2$ inch up, $\$ 5.50$ each, $\$ 50.00$ per 10 .

\section{Red Juice \& Red Flesh}

\section{Torocco Orange}

When you plant a red-fleshed orange, you want it real red-red in the flesh, with red juice, too. Here is an orange with the reddest flesh we have ever seen. And it's new-only recently imported from Sicily by the University of California and thoroughly tested by them. The fruit is of medium size, thin-skinned, smooth, rich orange on the outside with a slight red blush. On the inside-well, when you cut one open you'll hardly believe what you see! The flesh is rich deep crimson, and when you squeeze the juice it comes out bright ruby red. The tree will grow as vigorously and bear as well as any other orange. and the fruit is delicious to eat at any time. The flesh color may vary slightly with planting location and weather but it always has a distinctive grapelike flavor which you will enjoy. April and May.

$7257-2$-yr., caliper $1 / 2$ inch up, $\$ 6.50$ each, $\$ 60.00$ per 10 


\section{Piquant Limes}

Everyone knows that limeade prepared from fresh tangy limes is one of the most refreshing of all drinks. It is doubly good when you can use tree-fresh limes right from your own yard. Lime trees grow rapidly and bear soon after planting but they are more susceptible to frost than most other citrus varieties and are not adaptable to all areas. An excellent and very hardy substitute for the lime is the Calamondin described on page 91 .

\section{Bearss Seedless Lime}

The most widely planted of all limes for both home and orchard. It produces heavy crops of beautiful, seedless, highly acid fruits with a rich lime flavor. Most of its fruit ripens in the summer when limes are most in demand. The vigorous, glossy-foliaged tree is almost thornless. It makes a handsome tree in the home planting, usually loaded with fruit.

7195-Gal. tins, $\$ 1.50$. $7197-7-y$ r., $\$ 6.50$ each, $\$ 60.00$ per 10

\section{Rangpur Lime}

The handsome deep reddish orange fruits are as good inside as they look outside-even the flesh is orange. This is the most resistant to cold of any lime which we grow. With its big, white, fragrant blossoms, it is a splendid combination fruit tree and ornamental, particularly valuable for colder sections.

7205-Gal. tins, $\$ 1.50$.

7206-5-gal. tins, $\$ 4.75$.

\section{Big Juicy Lemons}

There are so many uses for lemons that no home garden should be without a tree. Most lemon varieties are not as hardy as orange trees, but for home use may safely be planted anywhere in California except in the cold interior or northern districts. The Meyer Lemon is hardy almost everywhere.

\section{Frost Eureka Lemon}

This is the newest and finest of California lemons for home planting or commercial orchard. It is a nucellar strain of the popular and widely planted Eureka, originated at the University of California Citrus Experiment Station. The tree has tremendous vigor and is resistant to virus diseases and growth weaknesses, which often show up in the old Eureka. The large, smooth-skinned, juicy fruit, almost seedless, is exactly the same as the Eureka, than which there is no better lemon. Ripens fruit coninuously throughout the year with the biggest crop in the summer, when you want it most. Starts producing while very young. $7165-1$-yr., caliper $1 / 2$ inch up, $\$ 5.50$ each, $\$ 50.00$ per 10 . 7166-2-yr., caliper $3 / 4$ inch up, $\$ 6.00$ each, $\$ 55.00$ per 10

\section{Pink-Fleshed Lemon}

In quality and flavor this variety is very similar to Eureka, of which it is a sport. There all similarity ends for the foliage of this kind is attractively striped and variegated in many shades of green, pink and white. The fruit is juicy and of excellent quality-just like the Eureka but it is amazingly striped in green and white, while the flesh and juice are a rich pink color. With its pink flower buds, this novel tree is exceedingly ornamental as well as useful.

$7180-$ Gal. tins, $\$ 1.50$.

\section{Grapefruit}

The juice and fruit of the grapefruit are unexcelled for providing those "top of the morning" vitamins. They can be grown with very little care in most of Southern California but there is a great deal of difference in the strains which are offered. We are confident that the buds from which Armstrong trees are grown are from the heaviest producing and best types now available.

\section{Marsh Seedless Grapefruit}

This is the standard of excellence in grapefruit and the best variety for California planting. The fruit is large, almost seedless, with a thin rind, abundant juice, and exceptionally fine flavor. The vigorous tree bears heavily everywhere although the thinner skin and sweeter fruit is produced in desert sections. Ripens December to May in the desert, May to August near the coast.

$$
7155-1 \text {-yr., caliper } 1 / 2 \text { inch up, } \$ 5.50 \text { each, } \$ 50.00 \text { per } 10 .
$$

\section{Ruby Grapefruit}

In desert sections, this new seedless grapefruit has the most beautiful bright red flesh imaginable. The red color even shows through, providing the skin with an attractive blush. In areas nearest the coast, like all other red grapefruit, it shows very little color, but in quality, it is equal to the Marsh Seedless. No matter where you plant it, it is the newest and best of the pinkfleshed grapef ruit. Plant Pat. No. 53.

7160-1-yr., caliper $1 / 2$ inch up, $\$ 6.00$ each, $\$ 55.00$ per 10 .

\section{Meyer Lemon Chinese Dwarf Lemon}

Not only does it ripen fruit through most of the year, but it is hardy enough to withstand even severe California frosts. The fruits are orange-colored, bigger, and juicier than the average lemon, and they make the finest lemon pie you have ever tasted. The tree is beautiful in appearance, has the biggest and most fragrant citrus blooms (not white but pink), and it grows easily anywhere in California from the coast to the hottest desert valley. It is not a commercial variety because it is too thin-skinned and juicy to ship well. However, it starts bearing while very young and even the small trees are loaded with the beautiful and extremely useful fruit. The Meyer Lemon is very adaptable to any home planting for it may be used as a single tree or a hedge or a large shrub or even as a pot plant.

$7170-$ Bush form, gal. tins, $\$ 1.25$ 7171-Bush form, 5-gal. tins, $\$ 4.25$. 7172-Espalier, 5-gal. tins, $\$ 6.50$ 7174-Tree form, 1-yr., caliper $1 / 2$ inch up, $\$ 6.00$ each, $\$ 55.00$ per 10

\section{Ponderosa Lemon}

If you want lemons that are really big, and we mean big (12 inches in circumference), this variety will provide them. You will not have to wait long either because the dwarf tree starts producing right now. With the exception of the Meyer Lemon, the small tree of Ponderosa is hardier than that of other lemons. 7185-Gal. tins, $\$ 1.50$.

The new Torocco Orange-flesh and juice are both a rich ruby red

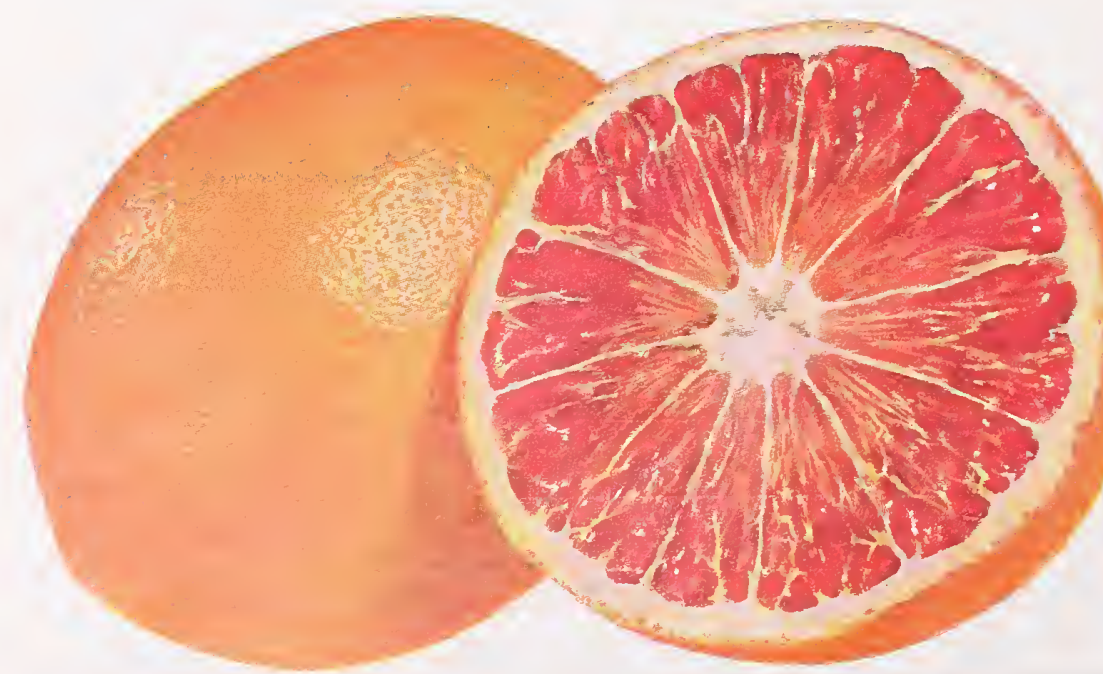




\section{Armstrong}

The evergreen avocados are not only one of the most handsome ornamental shade trees you can plant, but they will give you plenty of delicious fruit, rich in proteins, for the whole family to enjoy. Avocados can be successfully grown in many parts of California and you can pick out kinds that will give you fruit during the entire year. See table below.

\section{Armstrong Qualify Trees Insure Best Results}

We don't see how better avocado trees can be grown for your planting and when you see them we think you will agree. Armstrong avocado trees are all grown upon carefully selected hardy Mexican seedlings which are propagated in such a way as to insure the finest possible root development. The utmost care is used in the selection of the buds and because no effort or expense is spared in the growing you get a larger and better tree at Armstrong's than is generally found elsewhere. Our annual block of avocado trees, grown under the personal direction of Mr. L. E. Nigh for the last

Edranol is a fruit 38 years, is always a beautiful sight.

\section{When to Plant Avocados}

The black squares indicate the months for planting Avocados. The spring months are slightly preferable.

\section{Avocados Every Month in the Year}

\begin{tabular}{|c|c|c|c|c|c|c|}
\hline \multicolumn{7}{|c|}{$\begin{array}{l}\text { Avocado varieties vary considerably in their adaptation to different climatic condi- } \\
\text { tions in Southern California and there are some variations in the time of ripening. } \\
\text { To make it easy for you to pick out the kinds which are best for your location and } \\
\text { to enable you to have fruit throughout the year, we have made up the table below. } \\
\text { Opposite each month are listed the varieties which usually ripen their fruit during } \\
\text { that month in that particular zone. } \\
\text { Zone } 1 \text { is the Southern California Coastal Belt, from Santa Barbara to San Diego. } \\
\text { Zone } 2 \text { includes Mon rovia, La Habra Heights, Whittier, Tustin, Fullerton, La Mesa, } \\
\text { Escondido, Fallbrook, Vista and foothills of Santa Barbara and Ventura Counties. } \\
\text { Zone } 3 \text { is the Interior Belt from Pomona, east and from Corona, north; also North- } \\
\text { ern California. (Note minimum temperatures.) }\end{array}$} \\
\hline & \multicolumn{2}{|c|}{ ZONE 1} & \multicolumn{2}{|c|}{ ZONE 2} & \multicolumn{2}{|c|}{ ZONE 3} \\
\hline Jan. & Fuerte & Jalna & $\begin{array}{l}\text { Fuerte } \\
\text { Jalna }\end{array}$ & Zutana & $\begin{array}{l}\text { Fuerte } \\
\text { Jalna }\end{array}$ & Zutana \\
\hline Feb. & Fuerte & & Fuerte & & Fuerte & \\
\hline Mar. & Fuerte & & Fuerte & & Fuerte & \\
\hline Apr. & Fuerte & & Fuerte & & $\begin{array}{l}\text { Edranal } \\
\text { Fuerte }\end{array}$ & Ryan \\
\hline May & Edranal & Ryan & $\begin{array}{l}\text { Edranal } \\
\text { Hass }\end{array}$ & Ryan & $\begin{array}{l}\text { Edranal } \\
\text { Hass }\end{array}$ & Ryan \\
\hline June & $\begin{array}{l}\text { Anaheim } \\
\text { Edranal } \\
\text { Hass }\end{array}$ & $\begin{array}{l}\text { Nabal } \\
\text { Ryan }\end{array}$ & $\begin{array}{l}\text { Anaheim } \\
\text { Edranal } \\
\text { Hass }\end{array}$ & $\begin{array}{l}\text { Nabal } \\
\text { Ryan }\end{array}$ & $\begin{array}{l}\text { Edranal } \\
\text { Hass }\end{array}$ & Ryan \\
\hline July & $\begin{array}{l}\text { Anaheim } \\
\text { Edranal } \\
\text { Hass }\end{array}$ & $\begin{array}{l}\text { Nabal } \\
\text { Ryan }\end{array}$ & $\begin{array}{l}\text { Anaheim } \\
\text { Edranal } \\
\text { Hass }\end{array}$ & $\begin{array}{l}\text { Nabal } \\
\text { Ryan }\end{array}$ & $\begin{array}{l}\text { Edranal } \\
\text { Hass }\end{array}$ & Ryan \\
\hline Aug. & $\begin{array}{l}\text { Anaheim } \\
\text { Hass } \\
\text { Hellen }\end{array}$ & $\begin{array}{l}\text { Mexicala } \\
\text { Nabal } \\
\text { Ryan }\end{array}$ & $\begin{array}{l}\text { Anaheim } \\
\text { Hass } \\
\text { Hellen }\end{array}$ & $\begin{array}{l}\text { Mexicala } \\
\text { Nabal } \\
\text { Ryan }\end{array}$ & $\begin{array}{l}\text { Hass } \\
\text { Mexicala }\end{array}$ & Ryan \\
\hline Sept. & $\begin{array}{l}\text { Hass } \\
\text { Hellen } \\
\text { Mexicala }\end{array}$ & $\begin{array}{l}\text { Nabal } \\
\text { Ryan }\end{array}$ & $\begin{array}{l}\text { Duke } \\
\text { Hass } \\
\text { Hellen }\end{array}$ & $\begin{array}{l}\text { Mexicala } \\
\text { Nabal }\end{array}$ & $\begin{array}{l}\text { Duke } \\
\text { Hass }\end{array}$ & Mexicala \\
\hline Oct. & $\begin{array}{l}\text { Mexicala } \\
\text { Hellen }\end{array}$ & Hass & $\begin{array}{l}\text { Duke } \\
\text { Hellen }\end{array}$ & Mexicala & Duke & Mexicala \\
\hline Nav. & Jalna & & Jalna & Zutana & Jalna & Zutano \\
\hline Dec. & $\begin{array}{l}\text { Fuerte } \\
\text { Irving }\end{array}$ & Jalna & $\begin{array}{l}\text { Fuerte } \\
\text { Irving }\end{array}$ & $\begin{array}{l}\text { Jalna } \\
\text { Zutana }\end{array}$ & $\begin{array}{l}\text { Fuerte } \\
\text { Jalna }\end{array}$ & Zutana \\
\hline
\end{tabular}

\section{Sizes}

Our avocados are strong 1-year trees of heavy caliper, most of them 4 to 6 feet in height. Every salable Armstrong tree must be 3 feet or more in height.

\section{Shipping Weights}

Avocado trees are delivered with a ball of earth on the roots and they will average $55 \mathrm{lbs}$. each packed for shipment. See page 3 for data on shipment of balled trees. Special arrangements may be made to ship avocado trees for export or over greater distances with bare roots packed in moss and with the tops pruned back.

\section{They're Easy to Grow}

Avocado trees are easy to grow and will start readily if you follow the simple rules contained in the planting instructions which we send with your trees.

\section{Hardiness}

The minimum temperatures given after each variety are approximate only, since damage from frost varies greatly according to condition of the tree, time of year, and the location. Newly planted trees cannot be expected to withstand the minimum temperature indicated for the variety, and as a precaution should be given winter protection until they have become well established.

\section{Duke-a good hardy Avocado bearing crops like this}

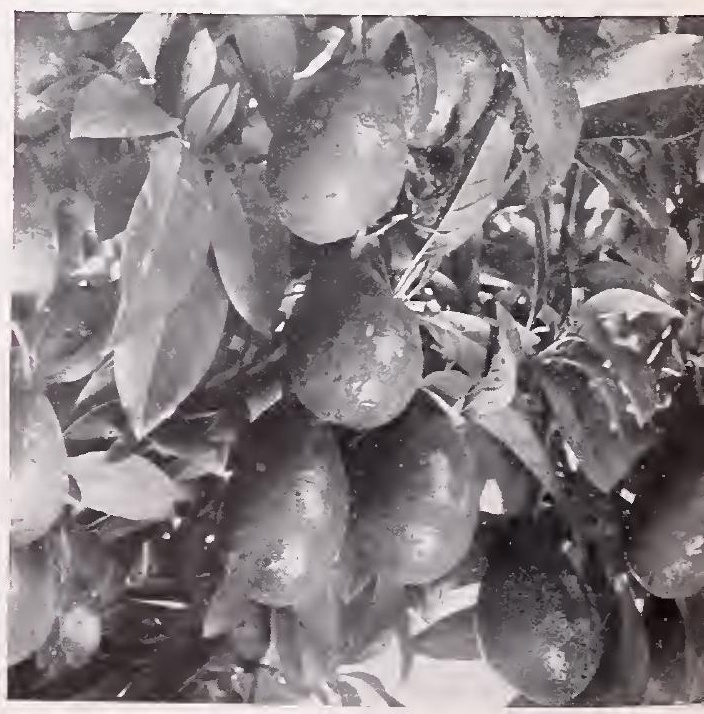




\section{Healthful \& Delicious}

Few fruits, if any, are more delicious or as rich in food value as avocados. In addition to their wonderful rich nutlike flavor and high protein content, they are one of the best natural sources of vitamin $A$ which can be found.

Everyone knows that avocados are recognized as the "King of Salad Fruits," but you can give yourself a variety of mouth-watering treats by using them in other ways, too. Used alone or in combination with cheese, meat or eggs, they make a delectable filling for sandwiches.

\section{Anaheim Tall, Slender Tree-Heavy Bearing}

A favorite with growers because it is probably the most prolific bearer of all varieties. The attractive oval, glossy green fruit is large and uniform in size. Although it is not of superb quality, it is a good market variety and profitable because of the extremely heavy crops. Its tall, slender habit of growth makes Anaheim valuable for inter-planting or for home planting where space is limited. Especially good in coastal or adjacent areas. May to August. $28^{\circ}$.

$7300-\$ 6.50$ each, $\$ 60.00$ per 10 .

\section{Duke For Interior Valleys and Colder Areas}

One of the finest of all avocados for home planting in the colder interior districts. It is an oval, green fruit which looks like a small Fuerte and is much larger than the average thin-skinned variety. A mild, pleasant flavor and smooth, clear flesh. Any surplus sells well on the local market for it is a fine appearing fruit. Duke will grow almost anywhere in the valleys of California from the northern end of the Sacramento Valley to the Mexican border, and the tree is large, vigorous, and beautifully foliaged. It is not a good bearer in the coastal districts, and does not always set a full crop each year in other areas, nevertheless it is one of the fastest growing trees of any avocado variety and for a large home shade tree in the interior areas it is unexcelled. Ripens September-October. $22^{\circ}$.

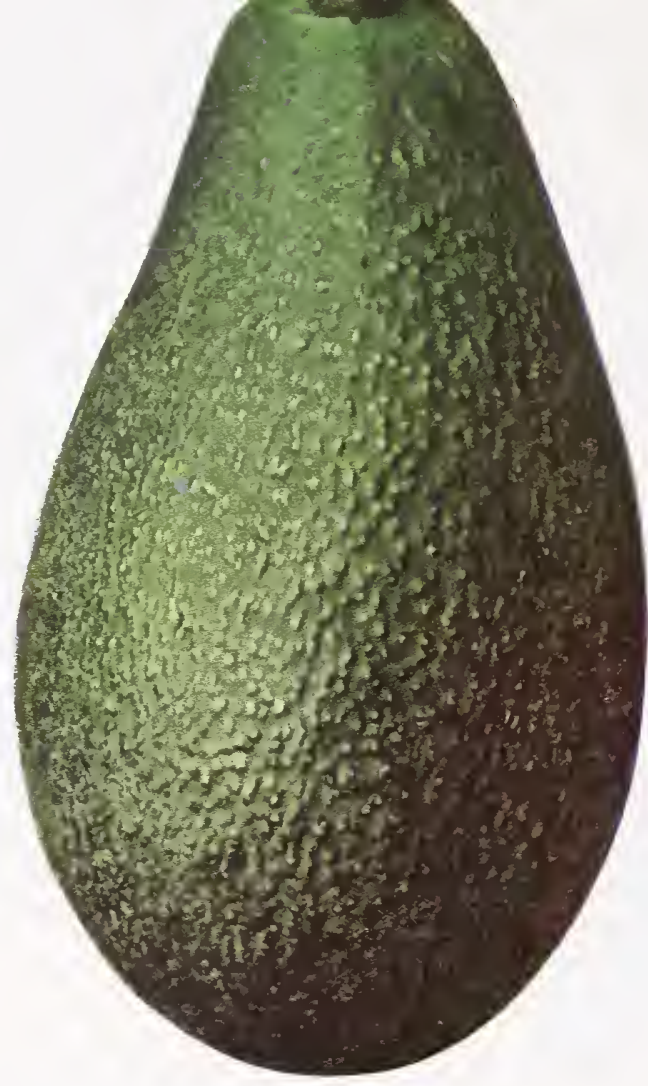

Fuerte-the leading commercial Avocado in California

\section{Edranol A Fruit of Fine Quality}

The dark green, pear-shaped fruits have a delicious, rich nutty flavor and the flesh is smooth and buttery without fiber and without discoloration when fully ripe. The seed is small so you get more for your money. The tree is a slender, vigorous upright grower, ideal for dooryard planting, and in most districts starts to bear when young and continues to bear heavily every season. It has done best in the interior regions, showing some bearing deficiencies in the coastal areas of San Diego, Los Angeles, and Ventura Counties. Resembling Fuerte, the fruit ripens in late spring and summer which gives it a great marketing advantage. Because of its fine quality, and since it is hardier than most of the "thick-skins" it has a permanent place among the top avocados. May to August. $26^{\circ}$. $\quad 7310-\$ 6.50$ each, $\$ 60.00$ per 10.

\section{Hass A Big Producer of Summer Fruit}

This medium size, purplish black avocado has jumped to the fore in the past several years and is now probably the leading summer-ripening commercial avocado, particularly in the coastal and foothill areas. The fruit has a rough skin, is elongated oval in shape, and is fine-flavored and generally high in quality. It has one of the longest ripening seasons in avocados, fruit maturing from May through October. An extremely heavy bearer in almost all sections-not only once in a while bu every year. Since its introduction, the Calavo Society has been rating it higher each year. Now it is near the top of the list of recommended varieties. Plant Pat. No. $139.26^{\circ}$. 7325- $\$ 8.00$ each, $\$ 75.00$ per 10

\section{Hellen A Big Tree Bearing Lots of Fruit Quickly}

This variety certainly does produce well and without delay. You are likely to have some fruit the first year after you plant. It is a pearshaped fruit of medium size, dark green, with a pebbled, leathery skin which peels off perfectly. It is of very fine flavor and quality, and has brought much higher than average prices on the market. The big spreading tree is one of the fastest growing and largest of all avocado trees. It has performed well in the coastal districts and is probably good in all foothill districts. Ripens August to October. $26^{\circ}$

$7335-\$ 6.50$ each, $\$ 60.00$ per 10

\section{Jalna A Good Hardy Thin-Skinned Variety}

A thin-skinned Mexican variety with green pear-shaped fruits of splendid quality. Wherever we have observed it the trees have borne heavy crops and the tree is one of the most beautiful of all avocados in appearance-spreading, symmetrical, with handsome luxuriant foliage. We are quite enthusiastic about this variety because we have seen many 2 or 3 -year-old trees literally hanging full of beautiful fruit, and we never fail to enjoy the fine quality and flavor. It has little competition in the early winter-ripening season. November-December. $22^{\circ}$

\section{Fuerte The Variety Most Widely Planted Commercially} Because of its high quality, heavy production, good marketability, winter-ripening season, and frost resistance, no variety exceeds it. According to market reports published by the Calavo Association, over 80 per cent of the avocado fruit marketed yearly is Fuerte. It is being grown successfully in all avocado districts, but produces best in the foothill areas intermediate between the coast and the hottest interior valleys. The fruit is pear-shaped, of medium size with a smooth green leathery skin and creamy yellow, buttery flesh-exceptionally fine in quality.

The tree is large and spreading, rather than upright, and it makes very attractive ornamental. The fruit ripens from late fall until early spring, and hangs on a long while after maturing. Although not as hardy as the thin-skinned Mexican kinds, Fuerte is considerably hardier than most avocados. We have checked many new strains of Fuerte, and believe that the Newman strain which we offer is the best. Ripens December to May. $24^{\circ}$. $7315-\$ 6.50$ each, $\$ 60.00$ per 10 .

Mr. John A. Armstrong, Vice President and General Manager of the Armstrong Nurseries, admires the big crop set on a young tree of Edranol

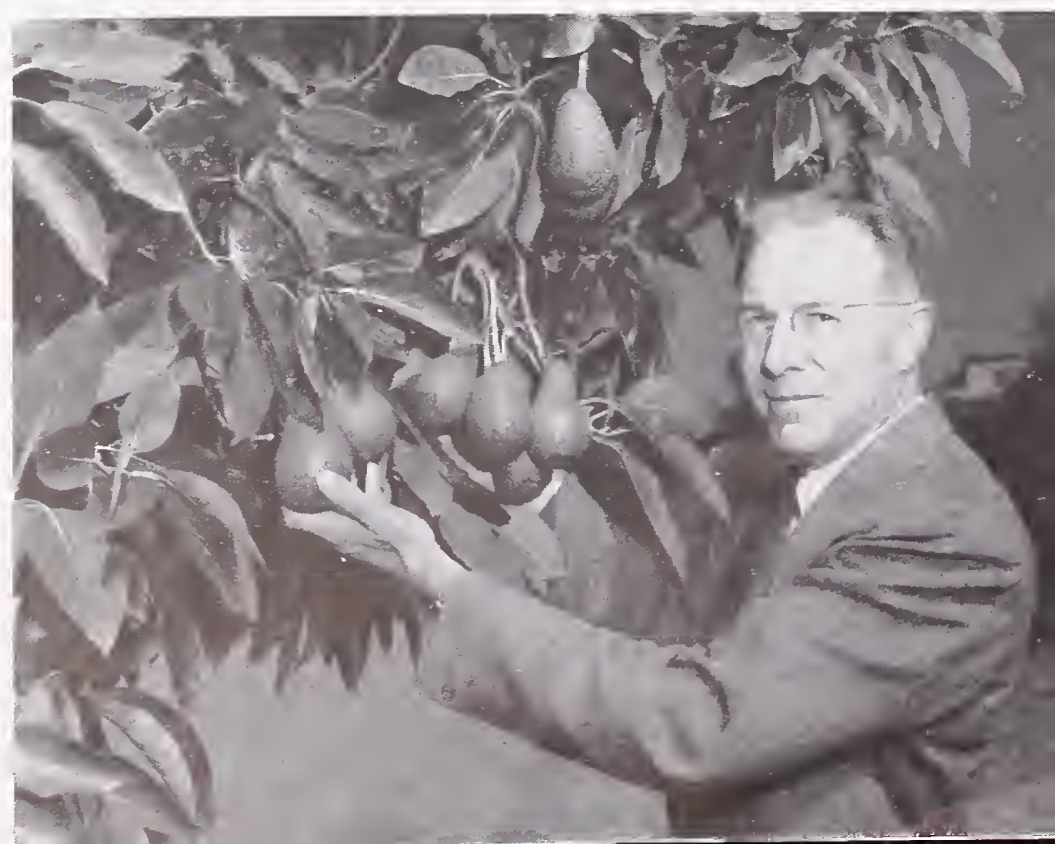




\section{Subtropical Fruiting Plants}

One of the most delightful things about owning a home place in California is that you can grow and enjoy so many interesting and unusual tropical and semi-tropical fruits. Many of them are quite ornamental and serve a double purpose of providing delicious unusual fruit and unusual good looks.

The temperature minimums indicated are approximate since the size and condition of the plant, the duration of below-normal cold spells and other factors influence the relative resistance to cold.

Shipping Weights: The average shipping weight of subeach; balled trees $50 \mathrm{lbs}$. each; gal. tins, $10 \mathrm{lbs}$. each. For shipping information see page 3 .

\section{When to Plant:}

The black squares under each month indicate that you can plant subtropicals during any month in the year (spring months slightly preferable).

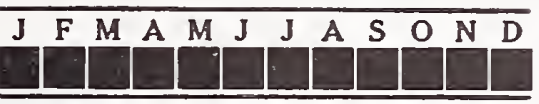

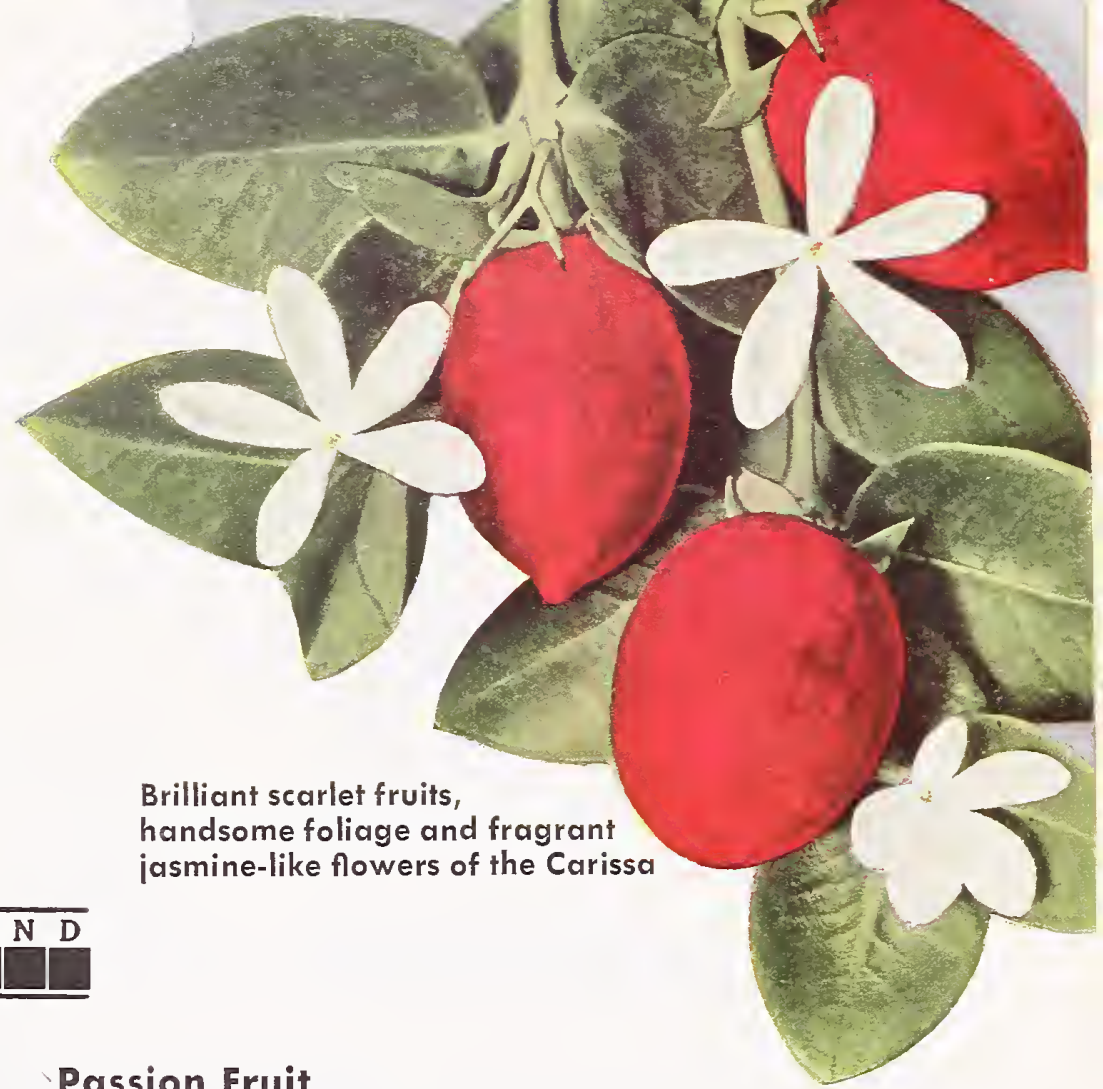

\section{Carissa grandiflora}

A lovely large spreading shrub from South Africa, uniquely beautiful in flower, fruit, and foliage. The rich glossy dark green leathery leaves make a splendid background for the intensely fragrant white blossoms and the brilliant scarlet fruits. The plant blooms most profusely in the early spring, but continues to flower throughout the year so that the tiny fruits and starlike flowers appear simultaneously. The plant naturally grows to a height of 6 or 8 feet with the same spread, but it may easily be pruned to any desired shape. The oftener the plant is trimmed the more attractive it becomes. The fruits are edible and particularly fine for use in preserves, making a delicious jam suggestive of cranberry sauce. The plant is not particular in its soil requirements and it will thrive in the extreme heat of the desert, or the cool moist weather of the coast-wherever the temperatures do not often drop below $26^{\circ}$. Sun or part shade.

$$
\text { 5045-Gal. tins, } \$ 1.50 \text {. 5046-5-gal. tins, } \$ 4.75
$$

\section{Carissa Alles}

This fine selected strain of Carissa has fruit half again as large as Carissa grandiflora-big, beautiful, scarlet fruits which make a show on the plant or in a fruit bowl. The shiny dark green foliage is somewhat larger, too, but the entire plant is lower growing and quite spreading in habit. The fruit ripens continuously, especially near the coast, but you must plant Carissa grandiflora nearby to insure a crop. Sun or part shade. $\quad 5040-$ Gal. tins, $\$ 1.50$. $5041-5$-gal. tins, $\$ 4.75$

\section{Passion Fruit}

This is a splendid ornamental fruiting vine which grows rapidly on a fence or pergola. The seed from which our plants are grown are taken from the largest fruiting types and heaviest bearing vines to be found in this state. This is important because inferior strains are sometimes sold. The glistening purple fruits, about the size of a hen's egg, are exceedingly fragrant and may be eaten fresh or used in many table delicacies. It is even used in the preparation of a very delicious juice. If you live in a frostless area, you can grow this handsome fruit and provide a beautiful mantle of glossy handsome foliage for that pergola, wall, fence, or building at the same time. The interesting flowers of sun. $28^{\circ}$.

$3470-$ Gal. tins, $\$ 1.75$.

\section{Rose-Apple (Syzygium jambos)}

A mass of broad, thick shining green and bronze foliage, 8 to 10 feet high Iuxuriant and handsome. Large snowy white flowers are followed by attractive small, creamy white rose-flushed fruit, $11 / 2$ to 2 inches in diameter, deliciously rose-scented. It may be eaten fresh or used to make fragrant jelly or candied fruit. You will find the clusters of pink and white fruits make beautiful table decorations, too. Does best in frostless coastal regions or foothill areas protected from the wind. Full sun or part shade. Likes plenty of moisture. $26^{\circ}$

$6586-5$-gal. tins, $\$ 6.00$ the Passion Fruit make an added attraction in the garden. Plant in full

\section{Grafted Feijoas}

A bowl of the fruit will fill a room with a delightful aroma suggestive of the combination of pineapples, strawberries, and bananas and the fruit is just as appetizing as the aroma promises. The plant is really handsome with its silvery green foliage, showy red and white spring flowers, followed by an abundance of fruit in the fall. These large-fruited grafted varieties should not be compared with ordinary seedlings, which usually bear small fruit or none at all. Feijoas are extremely hardy and will grow easily almost anywhere in California.

\section{Choiceana}

The fruit is the size of a large hen's egg, 3 inches by $21 / 4$ inches. This variety is the very finest feijoa, but Coolidge or Superba must be planted with it to insure cross-pollination. For a fine looking hedge or ornamental grouping plant Choiceana and Superba together, you will get plenty of fruit on both. 5525-Gal. tins, $\$ 1.75$ 5526-5-gal. tins, $\$ 5.25$.

\section{Coolidge}

A long oval fruit not quite as large as Choiceana or Superba, but which never fails to bear a crop even when planted by itself. 5530-Gal tins, $\$ 1.75$.

$5531-5$-gal. tins, $\$ 5.25$.

\section{Superba}

Beautiful, big, round fruits, almost as large as a billiard ball. Must have another variety with it to insure cross-pollination.
The Feijoa, or Pineapple Guava, is a handsome ornamental producing an abundance of delicious fruit

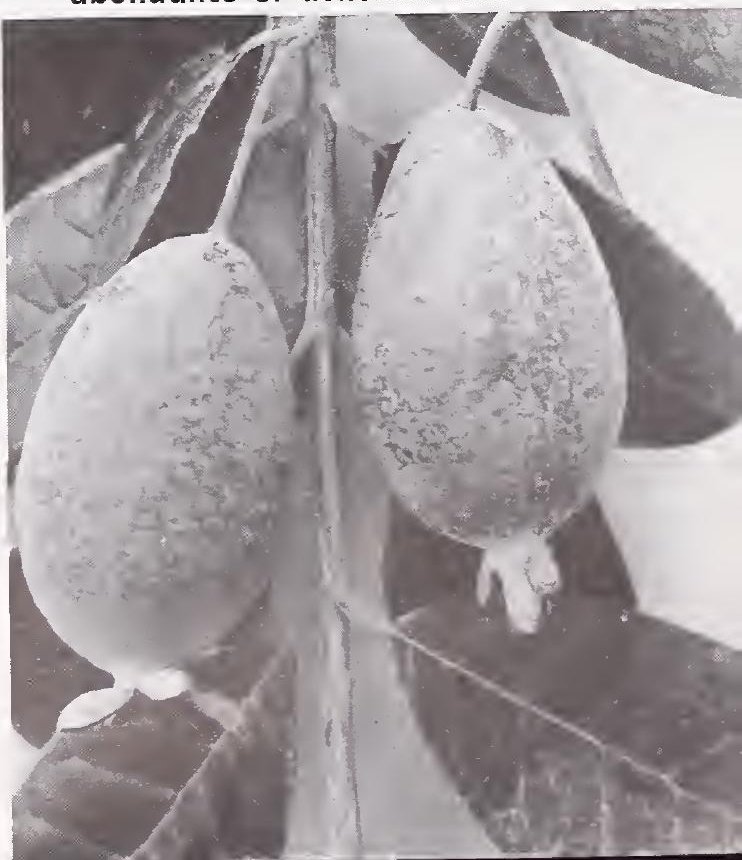




\section{Subtropicals}

\section{Luscious Cherimoyas}

The unique, large, green, heart-shaped fruits have a delicious, smooth, white flesh with the consistency of ice cream, and they ripen in winter when fruits are scarce. The trees are fast-growing and require about the same treatment as a citrus tree. They will normally produce fruit about the third year, but hand-pollination insures bigger crops (our salesmen will tell you how to do it). Balled Cherimoya trees weigh approximately $60 \mathrm{lbs}$.

Ott A New Heary Producing Kind

The original tree of this variety at Whittier, California, has never failed to produce a large crop without hand-pollination. The big, green fruits are smoother, with greater uniformity of shape than most other Cherimoyas and the skin peels away from the flesh easily. Ott has a high sugar content and a sweet, full-bodied flavor that will please the most jaded appetite. Plant Pat. No. 656. $26^{\circ}$

$3650-$ Balled, $1-y r$. trees, $\$ 8.50$ each, $\$ 80.00$ per 10.

Deliciosa Best for Cold and Wind

The most resistant variety to cold and wind. The fruit, although often small, is produced freely and regularly even without hand-pollination. The curious protuberances on the fruit which distinguish this variety do not in the least affect its value as a splendid home fruit. $25^{\circ}$.

$3645-$ Balled, $1-y r$. trees, $\$ 8.00$ each, $\$ 75.00$ per 10 .

Often called the "Ice Cream Fruit," there are few fruits as delicious as the Cherimoya, particularly when chilled

Chaffey Best Near the Coast

If you live near the coast, you can be sure that you are planting one of the very best for your section with this new variety. It stands out because of the heavy crops which it has produced in that area. The fruit is handsome and the flavor excellent. $26^{\circ}$. $3640-$ Balled, T-yr. trees, $\$ 8.00$ each, $\$ 75.00$ per 10.

\section{Armstrong California Olives}

From the northern end of the Sacramento Valley down to Old Mexico, olives are one of California's best paying orchard crops. They do well almost anywhere in California, thriving with a minimum of care and water.

\section{Ornamental Plantings}

Olive trees planted singly or in groups make very handsome and picturesque ornamentals, creating a typically California atmosphere. We have special unpruned trees of both Manzanillo and Mission for ornamental purposes in 5 -gal. tins and 20 -inch boxes. Also available are some extra-large specimens at $\$ 40$ to $\$ 50$ each. See page 31 for quantity rates on olives in 5 -gal. containers.

\section{Orchard Planting}

Olive trees for commercial orchard planting are field-grown and are furnished bare root. They should be planted from February to June for best results. The following quantity discounts apply on bare root olive trees of the same variety. Only the per tree rate is indicated under each variety.

$\begin{array}{ccc}\text { Each Price } & \text { Per } 10 & 50 \text { or more } \\ \$ 2.75 & \$ 25.00 & \$ 2.25 \text { each } \\ 3.00 & 27.50 & 2.50 \text { each }\end{array}$

\section{Mission}

The well-known variety introduced by the Spanish Padres. In fact, trees of this variety are still bearing fruit at some of the old missions. The tree is a very handsome ornamental, the fruit is very good for pickling, and the best of all for olive oil.

$1945-1 / 2^{\prime \prime}$ to $5 / 8^{\prime \prime}$ caliper, $\$ 2.75$. 1946-5/8" to $3 / 4^{\prime \prime}$ caliper, $\$ 3.00$ 6216-5-gal. tins, $\$ 4.75$. 6217-16-inch box, $\$ 20.00$

\section{Manzanillo}

This variety leads all others for commercial pickling in California. The fruit is slightly larger than that of Mission, of superb quality and fine for oil production, too.

$1940-1 / 2$ to $5 / 8$-inch caliper, $\$ 2.75$. $1941-5 / 8$ to $3 / 4$-inch caliper, $\$ 3.00$. $6211-5$-gal. tins, $\$ 4.75$. $6212-16$-inch box, $\$ 20.00$.

\section{Vitamin-Rich Guavas}

For eating fresh, but particularly for delicious jams and jellies, the Cattley and Yellow Cattley Guavas are among the finest small fruits which can be grown in California. With their beautiful glossy evergreen foliage, they make very handsome ornamental shrubs whether used singly or planted as a medium-sized hedge. They are quite hardy and seldom fail to set a generous crop of fruit rich in vitamins which ripens from September to November.

\section{Cattley Guava (Strawberry Guata)}

The handsome glossy-leaved medium sized shrub is quite hardy and can be grown in most of California. It produces an abundance of luscious deep red fruits about the size of a large strawberry, highly prized for eating when fresh and unequalled for jelly. A clump of 2 or 3 Cattley plants, planted as ornamentals or a short hedge, not only will give all-year beauty but will provide you with quantities of delicious fruit. 5 to $8 \mathrm{ft} .22^{\circ}$

5695-Gal. tins, \$1.25. 5696-5-gal. tins, \$4.25. fine to eat fresh, famous for jelly and a handsome ornamental plant

\section{Yellow Cattley Guava (Yellow Strawberry Guara)}

If you want plants of a little larger size, with slightly larger foliage, and yellow fruits a bit larger and a little milder in flavor, then this is the variety to plant. Some people prefer the milder flavor in the fresh fruit and it makes marvelous jelly, too. $24^{\circ}$.

\section{5-Gal. tins, \$1.25. $\quad 5716-5$-gal. tins, \$4.25.}

\section{Tropical Guava (Lemon Guar'a)}

Very large fruits as big as a pear, with a rather strong flavor. Grows rapidly to six or eight feet, has large, light green leaves, and does best in areas with considerable summer heat. This type is the most potent source of vitamin $C$ in fruits. $26^{\circ}$. 


\section{Loquats Bear Early}

The Loquat with its big, broad, attractive foliage makes a splendid small evergreen ornamental tree. It is hardy too, and thrives almost anywhere in Culifornia. The fruit with its sprightly aromatic flavor ripens in April and May when other fruits are scarce and loquat jelly is a real delicacy.

All varieties: Balled, 2-yr. trees, $\$ 7.00$ each, $\$ 65.00$ per 10 .

\section{Advance}

Large, pear-shaped, deep yellow fruits with a delicious juicy white flesh. One of the most beautiful of loquat trees and one of the heaviest bearers. March to June. $18^{\circ}$

\section{Champagne}

The big yellow-skinned, white-fleshed fruits are exceedingly juicy and richly flavored. Fine for both coastal and interior areas. For the warmer inland valleys, this variety and Advance are the best. Its zippy zestful flavor will please you and Champagne is just right for jelly. Ripens March to May. $18^{\circ}$.

\section{Gold Nugget}

The glossy, deep orange fruits of this splendid Loquat rate right at the top in appearance and flavor. The orange-fleshed Loquats are much sweeter than the white kinds and ripen later. They are at their best in coastal counties, but do well inland also. May to June. $18^{\circ}$

Gold Nugget Loquatlargest and sweetest

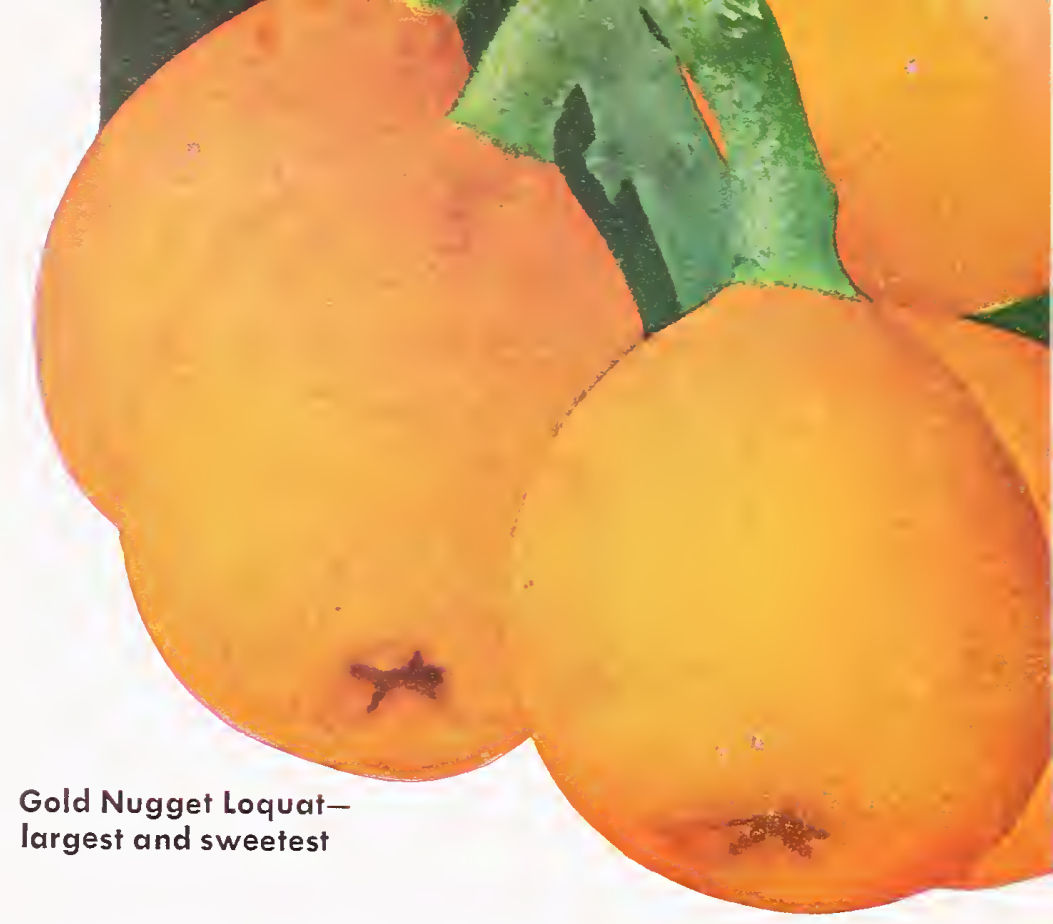

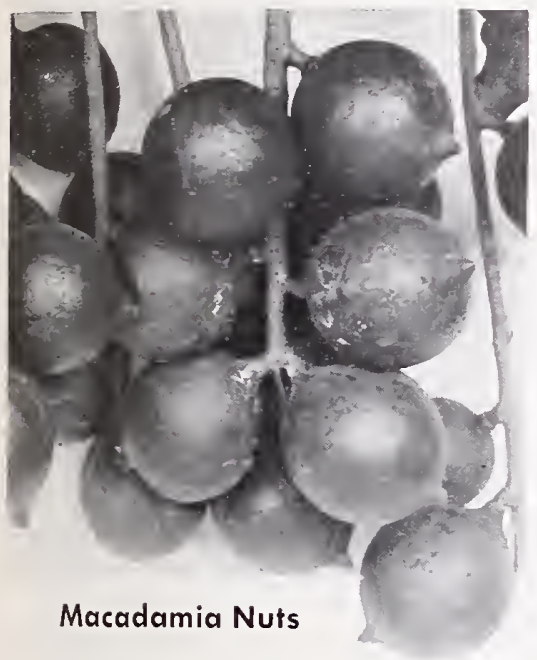

\section{Tropical Mango}

That most famous and most delicious of tropical fruits, the Mango, will grow and bear well in the frostless coastal and foothill regions of Southern California. The trees must be kept well mulched and given plenty of water. Every year we pick delicious fruits from selected seedling trees like those we offer here, grown within 10 miles of Ontario. $30^{\circ}$.

\section{Papaya Solo}

"Melons on trees"-that's what the Iuscious fruits resemble when hanging in bunches from the large-leaved tropical appearing plant. There are only a few Iocations in California where they will thrive so it is impossible to guarantee that they will grow successfully. They require a frost-free, sunny, well-drained location with plenty of water and fertilizer and must be kept growing rapidly. The flowers of each sex are borne on separate plants, so it is advisable to plant at least three to be reasonably sure of proper pollination.

$3460-$ Gal. tins, $\$ 2.50$.

\section{Macadamia Nut}

A handsome evergreen tree with a dense rounded head of long, narrow, dark green leaves, 20 to 35 feet in height. The nuts are about $11 / 4$ inches in diameter, round and hard shelled, but with a tender white kernel unbelievably rich in flavor. The trees usually begin to bear in 3 to 5 years after planting. They are vigorous, resistant to disease, and easily grown almost anywhere in Southern California, except in the very cold sections. 26

6056-5-gal. tins, $\$ 7.00$.

\section{Cherry of the Rio Grande}

\section{Myrciaria edulis}

Down along the Rio. Grande of Brazil it is highly prized for its delicious fruit and we can see why. The handsome evergreen tree reaches a height of about 15 feet, and every year it bears heavy crops of attractive fruit resembling a giant Tartarian Cherry in appearance and flavor. Brilliant scarlet, they turn to deep reddish purple when fully ripe. We think this is one of the finest new subtropical fruits to be introduced to California.
Cherry of the Rio Grande-Myrciaria edulis. Handsome foliage and cherrylike fruits, delicious to eat fresh and excellent for preserving

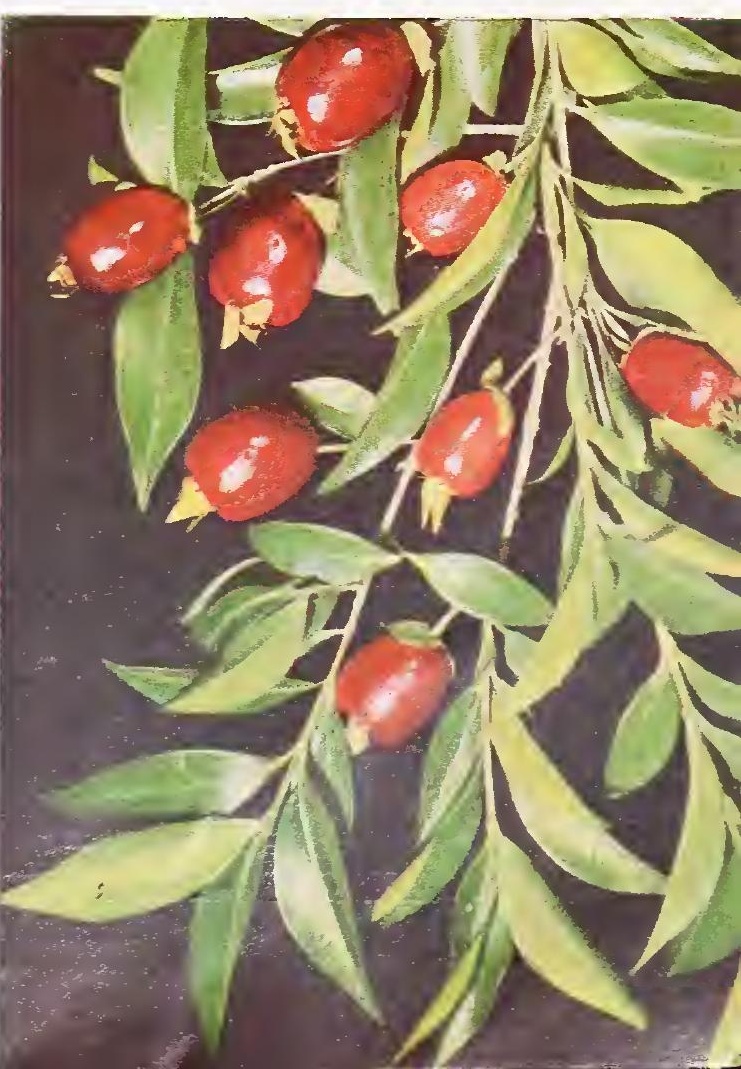




\section{Armstrong Garden Supplies \\ Grass Seed \\ Ground Covers}

When you purchase Armstrong Grass Seed, you are making the very best kind of a start toward a perfect lawn. Seeds vary greatly in grade, in percentage of germination, in freedom from wreed seed, and many other factors. We carry only the top grade of grass seed. You can find none better.

Write for prices on larger quantities. Prices subject to change without notice.

Armstrong Peerless Lawn The very finest lawn mixture that money can buy for any location. Made up largely of the best grades of Blue Grass, Clover and Bent, together with several other species which help to make up a perfect fine bladed lawn. One pound plants 200 square feet. $\quad \$ 1.65$ per lb.; 3 lbs. for $\$ 4.25 ; 10 \mathrm{lbs}$. for $\$ 13.25$.

Armstrong Dura-Lawn A good mixture for all locations, made up of choice top quality seed. While it makes a slightly coarser turf than Armstrong Peerless Lawn, this is the best mixture you will find at this price. One pound plants 200 square feet

$\$ 1.25$ per lb.; 3 lbs. for $\$ 3.50 ; 10$ lbs. for $\$ 9.75$.

Kentucky Blue Grass The basis for the best California lawns. There are a number of grades of Blue Grass, but ours is the best obtainable. One pound plants 150 square feet.

$\$ 1.70$ per lb.; 3 lbs. for $\$ 4.55 ; 10$ lbs. for $\$ 14.10$.

White Clover Makes a brilliant green lawn by itself, but is more often planted with Blue Grass. Gives quick results, and is fine for minter sowring in Bermuda Grass. One pound plants 200 square feet. $\$ 195$ per lb.; 3 lbs. for $\$ 5.20 ; 10$ lbs. for $\$ 16.00$.

Astoria Bent Makes the most luxuriant velvety green lawns in California, but takes extra care in watering and mowing. Good in shade. One pound plants 300 square feet.

$\$ 2.25$ per lb.; 3 lbs. for $\$ 6.15 ; 10$ lbs. for $\$ 18.70$.

Perennial Rye A hardy fast growing grass particularly good for hot climates. This is one of the few grasses which will make a satisfactory turf on the desert. Sun or shade. One pound to 100 square feet. 50 c per lb.; $3 \mathrm{lbs}$. for $\$ 1.30 ; 10 \mathrm{lbs}$. for $\$ 4.10$

Meadow Fescue Makes a fast growing durable turf which will take plenty of punishment. 85c per lb.; 3 lbs. for $\$ 2.30 ; 10$ lbs. for $\$ 7.15$.

Bermuda For hot dry locations and poor soil where other grasses will not thrive. One pound to 200 square feet. 60 c per lb.; 3 lbs. for $\$ 1.55 ; 10$ lbs. for $\$ 4.75$

\section{Peat Moss}

Peat moss is the perfect soil conditioner which helps you get better tesults with newly planted trees, shrubs and roses. Mix in liberally with your planting soil and be sure to wet thoroughly when mixing. The moisture holding capacity of peat moss will more than pay for its cost.

Large bales, $\$ 6.00$; half-bales, $\$ 3.50$

\section{Garden Fertilizers}

Vigoro As all-purpose lawn and garden fertilizer which supplies all the food elements needed by lawns, flowers, vegetables, shrubs and trees. A liberal application 3 or 4 times a vear provides a continuous balanced diet for proper growth and the production of fruit. $10 \mathrm{lbs}$. for $90 \mathrm{c} ; 25 \mathrm{lbs}$. for $\$ 1.65 ; 50 \mathrm{lbs}$. for $\$ 2.85 ; 100 \mathrm{lbs}$. for $\$ 4.75$.

Steer Fertilizer Always gets results. Not only provides plant food over a long period of time, but adds the humus generally needed in California soils.

Price is usually about $75 \mathrm{c}$ per sack.

Bandini Acid Food For acid-loving plants, such as Azaleas, Camellias, etc. An occasional application will supply not only food for these plants but will help keep the soil acid and to their liking. 5 lbs., 55 c; 10 lbs., $90 c$.

In addition to the above, we carry the All-Purpose Bandini Gro-Rite Milorganite and liquid fertilizers. In fact, we have a product we can recommend for every fertilizing need.

Pest Control At each of our five salesyards you will find a complete stock of materials for the effective control of pests on trees and plants. Ask one of our salesmen and he will tell you what to use for best results.
Listed below are a few recommended ground covers widely used in place of lawns. Most of them are easily cared for, grow under a wide range of conditions, and require no mowing. These and others, such as Mesembryanthemum, Ivy Geranium, etc., are available in season at any one of our five salesyards. They are furnished in flats, usually of 100 plants, or sufficient to plant about 200 square feet.

Prices vary slightly with the season.

Ajuga reptans A neat, uniform carpet of shiny deep green foliage all year. In spring and summer it sends up a myriad of dainty little bugle-like flowers. Shade and plenty of moisture.

Bermuda U-3 Recently released by the Turf Foundation of the University of California, this promises to fill a long-felt need in Southern California. It is a considerably finer bladed grass than regular Bermuda, yet it has the same ability to do well in poor soil and hot dry areas. Unlike ordinary Bermuda, U-3 will stay green throughout the entire year, remaining attractive during the winter months. It does not seed and sow itself in unwanted places nor does it make the big coarse runners which give an untidy look to the area bordering the lawn.

Dichondra repens A creeping ground cover which fills in rapidly and soon becomes a perfect solid green clover-like turf, resistant to weeds and requires no mowing or renovating. Use it in place of a lawn anywhere in sun or semi-shade.

Euonymus fortunei radicans $A$ Winter Creeper. A dense flat mat of large, deep green foliage, turning bright red in the winter but never dropping. Stands desert heat and will grow in any soil. Sun or shade. $0^{\circ}$.

Fragaria chiloensis Chilean Strawberry. A vigorous and luxuriant ground cover with handsome glossy leaves and small edible strawberries. Best for sunny locations. $5^{\circ}$.

Hedera helix All of the Ivies described in the vine section on page 61 may be used as ground covers, but one of the most satisfactory is Hedera helix or English Ivy. It is at home in sun or shade and will stand more cold than any other variety. $10^{\circ}$.

Helxine soleiroli Tiny round bright green leaves in a dense carpet. For moist shady places only. $15^{\circ}$

Lantana sellowiana Trailing Lantana. Good looking foliage and clouds of lavender blooms throughout most of the year. Fine for sunny banks or rock walls. $22^{\circ}$.

Lippia canescens A fast growing ground cover which soon makes a dense turf. Thrives in hot locations, poor soil; requires little water and will stand much abuse. $5^{\circ}$.

Lonicera japonica halliana Hall's Honeysuckle. Makes a good rapid-growing ground cover anywhere in sun or shade, in any soil. See page 62. Plant 2 feet apart. $0^{\circ}$.

\section{Protect Your Trees}

Paper Tree Profectors All young fruit trees and deciduous shade trees should be protected for the first season at least by the use of Tree Protectors or Tree White in order to prevent sunburn. Use 30-inch for Walnuts and Pecans; 24-inch for Peaches, Apples, Apricots, and other deciduous trees, and 18-inch for Citrus, Arocados, and Figs.

\begin{tabular}{|c|c|c|c|}
\hline & Each & Per 100 & Per 1000 \\
\hline - & $\$ 0.06$ & $\$ 4.00$ & 532.50 \\
\hline 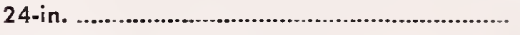 & .05 & 3.50 & 27.50 \\
\hline 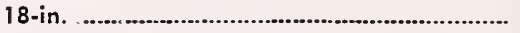 & .05 & 3.00 & 22.50 \\
\hline
\end{tabular}

Tree Trunk White An excellent preparation for painting tree trunks to preven sunburn. Simply mix the powder with water to the desired consistency. 1-lb. package, $25 \mathrm{c} ; 5$-lb. package, 95c; 25 lbs., $\$ 4.05$.

\section{Supplies to Satisfy Every Gardening Need at Each of} Our 5 Southern California Salesyards

Garden hose, sprinklers, lawn mowers, sprayers, and a complete line of garden tools, both large and small, are on display at each of our conveniently located salesyards. We can take care of your every gardening need with our complete line of gardening necessities and aids. 


\section{Armstrong Nurseries \\ Phone 627-61 \\ ONTARIO, CALIF.}

Use Other Side for Rose Order

Send Full Payment No C.O.D.'s

Sold to:

\section{Street Address}

City

State

\begin{tabular}{|c|c|c|c|}
\hline \multicolumn{3}{|c|}{ If ony item is out of stock, moy we sub- } & When to Ship: \\
\hline $\begin{array}{l}\text { CATALOG } \\
\text { NUMBER }\end{array}$ & $\begin{array}{l}\text { QUAN- } \\
\text { TITY }\end{array}$ & PLEASE USE & $\begin{array}{l}\text { ARTICLES WANTED } \\
\text { LAMES WHEN ORDE }\end{array}$ \\
\hline
\end{tabular}

Ship to:

Street Address

City

Zone

State

County

How to Ship:

We reserve the right to determine the method of shipment M. T. $\square \quad \mathbf{Z} \square$
Armstrong Nurseries will exercise care ta have merchandise true ta name. Provided it is expressly understaod that this order is accepted on the canditian precedent that it makes no warranfy, express ar implied, as ta description, quality, praductiveness, crops, ar any other matter whatsaever; that its Thatsaever is limited ta the purchose price; that arders shall be void should control and prevented or injury befall the stack from flaad, drouth, frast, ar other causes beyond it control and orders travel af risk of purchaser.
Totol (items this poge)

Packing or Delivery Charge (See poge 3)

TOTAL

Please tronsfer this totol to reverse of order sheet 
BARE ROOT ROSE ORDER BLANK

Armstrong bare root roses will be shipped at the proper planting time for your area. We pay shipping costs on them (except tree roses) anywhere in the United States.

\begin{tabular}{|c|c|c|c|c|c|c|c|c|c|c|c|}
\hline $\begin{array}{l}\text { Item } \\
\text { Na. }\end{array}$ & Quan. & Variety and Price & TOTAL & $\begin{array}{l}\text { Item } \\
\text { No. }\end{array}$ & Quan. & Variety and Price & TOTAL & $\begin{array}{l}\text { Item } \\
\text { Na. }\end{array}$ & Quan. & Variety and Price & TOTAL \\
\hline \multicolumn{4}{|c|}{ Bush Roses } & 1200 & & $\begin{array}{l}\text { NEW YORKER } \\
\$ 2.00 \text { each: } 3 \text { for } \$ 1.75 \text { each }\end{array}$ & & \multicolumn{4}{|c|}{ Climbing Roses } \\
\hline 1010 & & $\begin{array}{l}\text { APPLAUSE } \\
\$ 2.00 \text { each; } 3 \text { for } \$ 1.75 \text { each }\end{array}$ & & 1210 & & $\begin{array}{l}\text { NOCTURNE } \\
\$ 1.75 \text { each: } 3 \text { for } \$ 1.55 \text { each }\end{array}$ & & 1360 & & $\begin{array}{l}\text { BELLE OF PORTUGAL } \\
\$ 1.50 \text { each; } 3 \text { for } \$ 1.30 \text { each }\end{array}$ & \\
\hline 1012 & & $\begin{array}{l}\text { BRAVO } \\
\$ 2.25 \text { each; } 3 \text { for } \$ 2.00 \text { each }\end{array}$ & & 1220 & & $\begin{array}{l}\text { PEACE } \\
\$ 2.50 \text { each: } 3 \text { for } \$ 2.20 \text { each }\end{array}$ & & 1365 & & $\begin{array}{l}\text { BILLY BOILER } \\
\$ 1.50 \text { each; } 3 \text { for } \$ 1.30 \text { each }\end{array}$ & \\
\hline 1016 & & $\begin{array}{l}\text { CAPISTRANO } \\
\$ 2.25 \text { each; } 3 \text { for } \$ 2.00 \text { each }\end{array}$ & & 1230 & & $\begin{array}{l}\text { PICTURE } \\
\$ 1.25 \text { each; } 3 \text { for } \$ 1.10 \text { each }\end{array}$ & & 1375 & & $\begin{array}{l}\text { CHEROKEE PINK } \\
\$ 1.75 \text { each; } 3 \text { for } \$ 1.55 \text { each }\end{array}$ & \\
\hline 1025 & & $\begin{array}{l}\text { CHAR. ARMSTRONG } \\
\$ 2.00 \text { each; } 3 \text { for } \$ 1.75 \text { each }\end{array}$ & & 1235 & & $\begin{array}{l}\text { PINK BOUNTIFUL } \\
\$ 1.50 \text { each; } 3 \text { for } \$ 1.30 \text { each }\end{array}$ & & 1380 & & $\begin{array}{l}\text { CHEROKEE RED } \\
\$ 1.75 \text { each; } 3 \text { for } \$ 1.55 \text { each }\end{array}$ & \\
\hline 1030 & & $\begin{array}{l}\text { CHATTER } \\
\$ 1.50 \text { each; } 3 \text { for } \$ 1.30 \text { each }\end{array}$ & & 1240 & & $\begin{array}{l}\text { PINKIE } \\
\$ 1.75 \text { each: } 3 \text { for } \$ 1.55 \text { each }\end{array}$ & & 1385 & & $\begin{array}{l}\text { CHEROKEE WHITE } \\
\$ 1.75 \text { each; } 3 \text { for } \$ 1.55 \text { each }\end{array}$ & \\
\hline 1032 & & $\begin{array}{l}\text { CHIEF SEATTLE } \\
\$ 2.50 \text { each: } 3 \text { for } \$ 2.20 \text { each }\end{array}$ & & 1245 & & $\begin{array}{l}\text { PINOCCHIO } \\
\$ 1.50 \text { each: } 3 \text { for } \$ 1.30 \text { each }\end{array}$ & & 1390 & & $\begin{array}{l}\text { CL. CECILE BRUNNER } \\
\$ 1.75 \text { each; } 3 \text { for } \$ 1.55 \text { each }\end{array}$ & \\
\hline 1035 & & $\begin{array}{l}\text { CHINA DOLL } \\
\$ 1.75 \text { each: } 3 \text { for } \$ 1.55 \text { each }\end{array}$ & & 1250 & & $\begin{array}{l}\text { PRES. HERBERT HOOVER } \\
\$ 1.25 \text { each; } 3 \text { for } \$ 1.10 \text { each }\end{array}$ & & 1395 & & $\begin{array}{l}\text { CL. CHRIS. STONE } \\
\$ 1.75 \text { each; } 3 \text { for } \$ 1.55 \text { each }\end{array}$ & \\
\hline 1040 & & $\begin{array}{l}\text { CHRISTOPHER STONE } \\
\$ 1.25 \text { each; } 3 \text { for } \$ 1.10 \text { each }\end{array}$ & & 1255 & & $\begin{array}{l}\text { RADIANCE } \\
\text { \$1.25 each; } 3 \text { for } \$ 1.10 \text { each }\end{array}$ & & 1400 & & $\begin{array}{l}\text { CL. DAINTY BESS } \\
\$ 1.50 \text { each; } 3 \text { for } \$ 1.30 \text { each }\end{array}$ & \\
\hline 1045 & & $\begin{array}{l}\text { COUNTESS VANDAL } \\
\$ 1.50 \text { each: } 3 \text { for } \$ 1.30 \text { each }\end{array}$ & & 1260 & & $\begin{array}{l}\text { RED RADIANCE } \\
\$ 1.25 \text { each: } 3 \text { for } \$ 1.10 \text { each }\end{array}$ & & 1405 & & $\begin{array}{l}\text { CL, ETOILE DE HOLLANDE } \\
\$ 1.75 \text { each; } 3 \text { for } \$ 1.55 \text { each }\end{array}$ & \\
\hline 1050 & & $\begin{array}{l}\text { CRIMSON GLORY } \\
\$ 1.75 \text { each; } 3 \text { for } \$ 1.55 \text { each }\end{array}$ & & $12 \% 0$ & & $\begin{array}{l}\text { RUBAIYAT } \\
\text { \$1.75 each; } 3 \text { for } \$ 1.55 \text { each }\end{array}$ & & 1410 & & $\begin{array}{l}\text { CL GOLDEN DAWN } \\
\$ 1.75 \text { each; } 3 \text { for } \$ 1.55 \text { each }\end{array}$ & \\
\hline 1055 & & $\begin{array}{l}\text { DAINTY BESS } \\
\$ 1.25 \text { each: } 3 \text { for } \$ 1.10 \text { each }\end{array}$ & & 1275 & & $\begin{array}{l}\text { SAN FERNANDO } \\
\$ 1.75 \text { each; } 3 \text { for } \$ 1.55 \text { each }\end{array}$ & & 1415 & & $\begin{array}{l}\text { CL. GOLDEN RAPTURE } \\
\text { \$1.75 each; } 3 \text { for } \$ 1.55 \text { each } \\
\end{array}$ & \\
\hline 1060 & & $\begin{array}{l}\text { DEBONAIR } \\
\$ 1.75 \text { each: } 3 \text { for } \$ 1.55 \text { each }\end{array}$ & & 1285 & & $\begin{array}{l}\text { SHOW GIRL } \\
\text { \$1.75 each: } 3 \text { for } \$ 1.55 \text { each }\end{array}$ & & 1420 & & $\begin{array}{l}\text { CL. HINRICH GAEDE } \\
\$ 1.75 \text { each; } 3 \text { for } \$ 1.55 \text { each }\end{array}$ & \\
\hline 1070 & & $\begin{array}{l}\text { ECLIPSE } \\
\$ 1.75 \text { each: } 3 \text { for } \$ 1.55 \text { each }\end{array}$ & & 1290 & & $\begin{array}{l}\text { SIGNORA } \\
\$ 1.75 \text { each: } 3 \text { for } \$ 1.55 \text { each }\end{array}$ & & 1425 & & $\begin{array}{l}\text { CL. K. A. VICTORIA } \\
\$ 1.75 \text { each; } 3 \text { for } \$ 1.55 \text { each }\end{array}$ & \\
\hline 1075 & & $\begin{array}{l}\text { ETOILE DE HOLLANDE } \\
\$ 1.50 \text { each: } 3 \text { for } \$ 1.30 \text { each }\end{array}$ & & 1295 & & $\begin{array}{l}\text { SNOWBIRD } \\
\$ 1.50 \text { each: } 3 \text { for } \$ 1.30 \text { each }\end{array}$ & & 1435 & & $\begin{array}{l}\text { CL MCGREDY'S IVORY } \\
\$ 1.75 \text { each: } 3 \text { for } \$ 1.55 \text { each }\end{array}$ & \\
\hline 1076 & & $\begin{array}{l}\text { FANDANGO } \\
\$ 2.00 \text { each: } 3 \text { for } \$ 1.75 \text { each }\end{array}$ & & 1300 & & $\begin{array}{l}\text { SUMMER SNOW } \\
\$ 1.50 \text { each: } 3 \text { for } \$ 1.30 \text { each }\end{array}$ & & 1440 & & $\begin{array}{l}\text { CL. MRS. SAM MCGREDY } \\
\$ 1.75 \text { each; } 3 \text { for } \$ 1.55 \text { each }\end{array}$ & \\
\hline $10 \pi$ & & FASHION & & 1301 & & $\begin{array}{l}\text { SUTTER'S GOLD } \\
\$ 2.25 \text { each: } 3 \text { for } \$ 2.00 \text { each }\end{array}$ & & 1445 & & $\begin{array}{l}\text { CL. NIGHT } \\
\$ 1.75 \text { each; } 3 \text { for } \$ 1.55 \text { each }\end{array}$ & \\
\hline 1080 & & $\frac{\$ 2.00 \text { each; } 3 \text { for } \$ 1.75 \text { each }}{\text { FIESTA }}$ & & 1305 & & $\begin{array}{l}\text { SWEET SIXTEEN } \\
\text { \$1.75 each; } 3 \text { for } \$ 1.55 \text { each }\end{array}$ & & 1446 & & $\begin{array}{l}\text { CL. PEACE } \\
\$ 2.50 \text { each } ; 3 \text { for } \$ 2.20 \text { each }\end{array}$ & \\
\hline 2000 & & $\begin{array}{l}\$ 1.75 \text { each: } 3 \text { for } \$ 1.55 \text { each } \\
\text { FIRST LOVE }\end{array}$ & & 1310 & & $\begin{array}{l}\text { TAFFETA } \\
\$ 1.75 \text { each; } 3 \text { for } \$ 1.55 \text { each }\end{array}$ & & 1450 & & $\begin{array}{l}\text { CL, PICTURE } \\
\$ 1.75 \text { each: } 3 \text { for } \$ 1.55 \text { each }\end{array}$ & \\
\hline 1082 & & $\begin{array}{l}\text { FIRST LOVE } \\
\$ 2.25 \text { each: } 3 \text { for } \$ 2.00 \text { each }\end{array}$ & & 1315 & & $\begin{array}{l}\text { TALISMAN } \\
\$ 1.25 \text { each; } 3 \text { for } \$ 1.10 \text { each }\end{array}$ & & 1452 & & $\begin{array}{l}\text { CL. PINKIE } \\
\$ 2.75 \text { each; } 3 \text { for } \$ 2.40 \text { each }\end{array}$ & \\
\hline 1085 & & $\begin{array}{l}\text { FLORADORA } \\
\$ 1.50 \text { each; } 3 \text { for } \$ 1.30 \text { each }\end{array}$ & & 1320 & & $\begin{array}{l}\text { TALLYHO } \\
\$ 2.00 \text { each; } 3 \text { for } \$ 1.75 \text { each }\end{array}$ & & 1455 & & $\begin{array}{l}\text { CL. PRES. HOOVER } \\
\$ 1.50 \text { each; } 3 \text { for } \$ 1.30 \text { each }\end{array}$ & \\
\hline 1090 & & $\begin{array}{l}\text { FORTY-NINER } \\
\text { \$2.00 each; } 3 \text { for } \$ 1.75 \text { each }\end{array}$ & & 1325 & & $\begin{array}{l}\text { TEXAS CENTENNIAL } \\
\$ 1.75 \text { each }: 3 \text { for } \$ 1.55 \text { each } \\
\end{array}$ & & 1460 & & $\begin{array}{l}\text { CL. SHOW GIRL } \\
\$ 1.75 \text { each; } 3 \text { for } \$ 1.55 \text { each }\end{array}$ & \\
\hline 1095 & & $\begin{array}{l}\text { FRAU KARL DRUSCHKI } \\
\$ 1.25 \text { each; } 3 \text { for } \$ 1.10 \text { each }\end{array}$ & & 1330 & & $\begin{array}{l}\text { THE CHIEF } \\
\$ 1.75 \text { each; } 3 \text { for } \$ 1.55 \text { each }\end{array}$ & & 1465 & & $\begin{array}{l}\text { CL. TALISMAN } \\
\$ 1.50 \text { each; } 3 \text { for } \$ 1.30 \text { each }\end{array}$ & \\
\hline 1100 & & $\begin{array}{l}\text { FRED EDMUNDS } \\
\$ 1.75 \text { each; } 3 \text { for } \$ 1.55 \text { each }\end{array}$ & & 1340 & & $\begin{array}{l}\text { VALENTINE } \\
\$ 2.00 \text { each: } 3 \text { for } \$ 1.75 \text { each }\end{array}$ & & 1470 & & $\begin{array}{l}\text { CL } \text { TEXAS CENTENNIAL } \\
\$ 1.75 \text { each: } 3 \text { for } \$ 1.55 \text { each }\end{array}$ & \\
\hline 1102 & & $\begin{array}{l}\text { FRED HOWARD } \\
\$ 2.75 \text { each: } 3 \text { for } \$ 2.40 \text { each }\end{array}$ & & 1345 & & $\begin{array}{l}\text { VOGUE } \\
\$ 2.25 \text { each; } 3 \text { for } \$ 2.00 \text { each }\end{array}$ & & 1480 & & $\begin{array}{l}\text { HIGH NOON } \\
\$ 2.00 \text { each; } 3 \text { for } \$ 1.75 \text { each }\end{array}$ & \\
\hline 1105 & & $\begin{array}{l}\text { GIRONA } \\
\$ 1.25 \text { each; } 3 \text { for } \$ 1.10 \text { each }\end{array}$ & & \multirow{3}{*}{\multicolumn{4}{|c|}{$\begin{array}{l}\text { Tree Roses } \\
\text { Bare Root, } \$ 5.00 \text { each; } \$ 45.00 \text { per 10. Ten assorted } \\
\text { Tree Roses sold at the 10-rate. Add 50c each for } \\
\text { packing and mailing charges. }\end{array}$}} & 1490 & & $\begin{array}{l}\text { MERMAID } \\
\text { \$2.25 each; } 3 \text { for } \$ 2.00 \text { each }\end{array}$ & \\
\hline 1110 & & $\begin{array}{l}\text { GOLDEN RAPTURE } \\
\$ 1.25 \text { each; } 3 \text { for } \$ 1.10 \text { each }\end{array}$ & & & & & & 1495 & & $\begin{array}{l}\text { MME. GR. STAECHELIN } \\
\$ 1.50 \text { each } ; 3 \text { for } \$ 1.30 \text { each }\end{array}$ & \\
\hline 1115 & & $\begin{array}{l}\text { GOLDILOCKS } \\
\$ 1.50 \text { each; } 3 \text { for } \$ 1.30 \text { each }\end{array}$ & & & & & & 1500 & & $\begin{array}{l}\text { PAUL'S SCARLET } \\
\text { \$1.50 each: } 3 \text { for } \$ 1.30 \text { each } \\
\end{array}$ & \\
\hline 1120 & & $\begin{array}{l}\text { GR. DUCH. CHARLOTTE } \\
\$ 1.75 \text { each; } 3 \text { for } \$ 1.55 \text { each }\end{array}$ & & 1519 & & \begin{tabular}{|l|} 
BRAVO \\
CHARLOTTE ARMSTRONG \\
\end{tabular} & & \multicolumn{4}{|c|}{ Special Collections } \\
\hline 1125 & & $\begin{array}{l}\text { HEART'S DESIRE } \\
\$ 1.75 \text { each: } 3 \text { for } \$ 1.55 \text { each }\end{array}$ & & 1540 & & DEBONAIR & & 1001 & & $\begin{array}{l}\text { ALL-AMERICA COLL. } \\
\$ 9.70\end{array}$ & \\
\hline 1127 & & $\begin{array}{l}\text { HELEN TRA UBEL } \\
\$ 2.75 \text { each; } 3 \text { for } \$ 2.40 \text { each }\end{array}$ & & 1546 & & $\begin{array}{l}\text { FANDANGO } \\
\text { FIRST LOVE }\end{array}$ & & 1002 & & $\begin{array}{l}\text { ARMSTRONG “BIG 10" } \\
\$ 17.25\end{array}$ & \\
\hline 1130 & & $\begin{array}{l}\text { HORACE McFARLAND } \\
\$ 1.75 \text { ea }=\mathrm{h} ; 3 \text { for } \$ 1.55 \text { each }\end{array}$ & & 1550 & & FORTY-NINER & & 1003 & & $\begin{array}{l}\text { ALL-ARMSTRONG FIVE } \\
\$ 8.60\end{array}$ & \\
\hline 1136 & & JUNO & & $\frac{1561}{1572}$ & & $\begin{array}{l}\text { HELEN TRAUBEL } \\
\text { LOWELL THOMAS }\end{array}$ & & 1004 & & $\begin{array}{l}52 \text { COLLECTION } \\
\$ 4.60\end{array}$ & \\
\hline \multirow{2}{*}{1140} & & $\begin{array}{l}\$ 2.00 \text { each; } 3 \text { for } \$ 1.75 \text { each } \\
\text { K. A. VICTOR IA }\end{array}$ & & $15 \% 5$ & & MIRANDY & & 1005 & & $\begin{array}{l}\text { SHOW TIME COLL. } \\
\$ 6.40\end{array}$ & \\
\hline & & $\begin{array}{l}\text { K. A. VICTORIA } \\
\$ 1.50 \text { each; } 3 \text { for } \$ 1.30 \text { each }\end{array}$ & & 1585 & & NOCTURNE & & 1006 & & $\begin{array}{l}\text { JACKPOT COLLECTION } \\
\$ 6.15\end{array}$ & \\
\hline 1150 & & LOWELL THOMAS & & 1595 & & $\begin{array}{l}\text { PICTURE } \\
\text { SHOW GIRL }\end{array}$ & & 1007 & & $\$ 6.25$ & \\
\hline & & $\$ 2.00$ each; 3 for $\$ 1.75$ each & & 1615 & & SNOWBIRD & & & & & \\
\hline 1165 & & $\begin{array}{l}\text { McGREDY'S IVORY } \\
\$ 1.25 \text { each; } 3 \text { for } \$ 1.10 \text { each }\end{array}$ & & 1616 & & SUTTER'S GOLD & & & & lotal Roses & \\
\hline 1170 & & $\begin{array}{l}\text { MIRANDY } \\
\$ 1.75 \text { each; } 3 \text { for } \$ 1.55 \text { each }\end{array}$ & & & Flori & bunda Tree Roses & & & & Total from Other Page & \\
\hline 1176 & & $\begin{array}{l}\text { MISSION BELLS } \\
\$ 2.25 \text { each; } 3 \text { for } \$ 2.00 \text { each }\end{array}$ & & $\begin{array}{l}\text { Prices a } \\
\text { standord }\end{array}$ & In Flarib & $\begin{array}{l}\text { oundo Tree Rases same as } \\
\text { loses abave. }\end{array}$ & given far & & & California Orders & \\
\hline 1180 & & $\begin{array}{l}\text { MME. CHIANG KAI-SHEK } \\
\$ 1.75 \text { each: } 3 \text { for } \$ 1.55 \text { each }\end{array}$ & & 1650 & & FASHION & & & & Add $3 \%$ Sales Iax & \\
\hline 1185 & & MME. HENRI GUILLOT & & 1655 & & GOLDILOCKS & & & & $\begin{array}{l}\text { Tree Rose } \\
\text { Packing Charge }\end{array}$ & \\
\hline & & $\$ 1.75$ each: 3 for $\$ 1.55$ each & & 1660 & & PINKIE & & & & & \\
\hline 1190 & & $\begin{array}{l}\text { MRS. E.P. THOM } \\
\$ 1.25 \text { each; } 3 \text { for } \$ 1.10 \text { each }\end{array}$ & & $\frac{1665}{1670}$ & & $\begin{array}{l}\text { VALENTINE } \\
\text { VOGUE }\end{array}$ & & & & Total Amount Enclosed & \\
\hline
\end{tabular}




\section{Complete Index}

\section{Fruits}

$\mathbf{A}_{\text {pples }}^{\text {lmonds ............80.81 }}$ Apricots ...........73 Artichokes ........90

Asparagus ..........90

Avocados ........94.96

$\mathbf{B}_{\text {erries }}^{\text {…....8.86-87 }}$ Backberries $\ldots \ldots .86$
Boysenberries $\ldots \ldots .86$

$C^{\text {alamondin }} . . . . .991$ arissa $\ldots \ldots \ldots \ldots 97$
Clerimoyas ..........98 Cherries …...... 82 Cherry of the Rio

Grande ..........99 Citrus .........91-93 Citrus, Dwarf.....91-92 Crabapple .........81 Currants …......86

D warf Pears......79

$\mathbf{E}^{\text {spalier Grapes....90 }}$

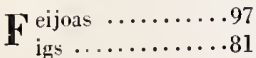

$\mathbf{G}^{\text {ocseberries ......86 }}$ rapefruit ........99
Grapes ......... 88.90 Grapes, Grafted.....90 Guavas ............98

$\mathbf{J}^{\text {ujubes }} . . . . . . . . .884$

$\mathbf{K}_{\text {orean Cherries...82 }}$

L emons ............93

imequat .........91

Loganberry .........86

Loquats ...........99

$\mathbf{M}^{\text {acadamia }}$.......99

Nango ............99

Nyrciaria .........999

$\mathbf{N}$ ectarines $\ldots \ldots .78$

$\mathbf{O}^{\text {lives .............98 }}$

$\mathbf{P}$ apayas ..........99 assion Fruit......97 Pears .............79

Pecans ............ 85

Persimmons ........84

Planting Distances...30

Plums ............ 83

Pomegranate …..84

Prunes ............. 82

Q

$\mathbf{R}_{\text {aspherries } \ldots .86-87}$ Rose-Apple ….....97

$\mathbf{S}$ apotes ..........99 Subtropicals ....94.99 Syzygium ….....97

$\mathbf{T}^{\text {angelos }} \ldots \ldots \ldots .92$

$W^{\text {alnuts } \ldots \ldots \ldots 85}$ alnuts, Black...85

$Y^{\text {oungberry }} \cdots \ldots .86$

\section{Ornamentals}

$\mathbf{A}_{\text {butilon . . . . . . . . } 40}^{\text {belias }}$

Acacias ...........56

Acanthus . .......... 40

ccr $\ldots \ldots \ldots \ldots \ldots 68$

Adenocarpus ........40

Agapanthus …....40

juga..$\ldots \ldots \ldots 100$

Anemones .........66

Antigonon .........60

Arborvitaes .......665

Arbutus ............40

Arctotis .........66

Arecastrum .........59

Ash ........... 58, 68

Asters ........41,66

Aucuba .........41

Australian Bluebell

Creeper $\ldots . . . \ldots . .54$
ustralian Brush

Australian Brush
Cherry .........46

Australian Fuchsia ..44

Azaleas ..........32-33

B amboos $\ldots . . .559$

Barberries …........41

Bauhinias .........56

Beautybush ........71

Beloperone …....41

Berberis ..........4

Bergenia .........4

Betula ...........68

Birch ...........68

Bird-of-Paradise …55

Bletilla ...........66

Bluc Chaste Tree....72

Blue Plumbago ...42, 66

Boston Ivy........62

Bottle Brush.......42

Bottle Tree.........56

Bougainvillea ......60

Bouvardias .........41

Boxwood ….........4

Brachychiton …....56

Brassaia ..........4l

Brazil Sky Flower...45

Breath of Heaven....44

Bridal Wreath......72

Brunfelsia .........

Buddleias .........41

Bush Poppy.......45

Calla Lily.........6

$\mathbf{C}_{\text {alliandra }} \ldots \ldots \ldots .42$

Callistemon .......42

California Holly.....53

California Lilac.....42

Calodendrum .......56

Camellias ........34.39

Campanula .......66

Camplor Tree......56

Campsis ........6.60

Canary-Bird Flower..44

Canary Island Lupine 40

Cannas ..........66

Cape Honeysuckle . . .63

Carissa ............42

Carnation-Flowered

Pomegranate ....53

Carolina Jessamine . .61

Carpenteria .......42

Carob ............ 57

Cassia ...........42

Catalina Cherry.....53

Cat-claw Trumpet ...61

Ceanothus .........42

Cedar ............64

Celtis ...........68

Ceratonia ........57

Ceratostigma $\cdots 42,66$

Cestrum parqui ......43
Chaenomeles ......
Chamaecyparis ....6.64.

Chamaelaucium ….43

Chaste Tree........7

Chilopsis

imonanthus

Elmes........70

Chinese Hat Plant ....50

Chinese Photinia....52

Chinese Plumbago...42

Flowe

Geranium

Gerberas

Ginger Lilies

Glossy-Leaved

Creeper

Gold Dust Plant.

Gold Flower.

Golden Wonder

Grasses .......... 100

Grevillea …..48,58

Ground Covers....100

Guinea Gold Vine...61

$\mathbf{H}_{\text {alesia }}^{\text {ack } \ldots \ldots \ldots \ldots .6 .68}$

Correas ............

Corsage Vine.....63

Cortaderia

Cotinus

Cotoneasters

Creeping Fig ...

Crepe Myrtle.

Crotalaria .........4t

Cup of Gold ........62

Cymbidiums .......46

D) aboeria $\ldots \ldots \ldots 44$

Daphne .......... 5

Daylilies

Deciduous Shruls 70-72

Deeiduous Trees . 68.70

Dendromecon ......45

Deodars

Desert Willow...... 71

Dianella ...........45

Dichondra ....... 100

Dimorphotheca. .666

Distictis $\ldots \ldots \cdot 661$

Doxantla $\ldots . . .6 .61$

Duranta

$E_{\text {chium }}^{\text {...........45 }}$

Elms ............ 59,70

Eranthemum …...45

Ericas ….......47

Escallonias ........45

Eucalyptus …....57

Eugenia $\ldots \ldots \ldots \ldots 46$

Euonymus ........46

Euphorbia …....46

Euryops ...........46

Evergrcen Grape ....60 60

Evergreen Pear......54

Evergreen Shrubs 40-55

Evergreen Trees. . .56-59

$\mathbf{F}_{\text {atsia }}^{\text {atshedera } \ldots \ldots . .46}$

Feathery Cassia .....42

Felicia .........66 66

Ferns ............48

Fern Pine........65

Ficus ........ 58,6I

Firefall Bush .......44

Firethorn ….....53

Flame Pea $. . . \ldots . .43$

Flame Tree........56

Flame Vine.......62

Flax $\ldots \ldots \ldots \ldots 60.60$

Flowering Cherry...66
Flowering Crab....669

Flowering Peach....66

Harden bergia

Hawtlorn

Heathers

Heavenly Bamboo....

Heder

Hedychium

Helianthus

Heliotrope

Helxine

Hemerocallis

Herb

Hibbertia .........6.

Hibiscus …....49, 71

Hollies .............50
Hollyleaf Cherry....53

Hollyleaf Cherry....553
Holmskioldia .....5.50

Honevsuckles .....662

Hydrangeas …48, 71

Hymenosporum …558

Hypericum …....50

$\mathbf{I}_{\text {ncense }}^{\text {lex }}$ Cedar......6.64

Indian Laurel .......58

Irish Heath ........44

Irish Yew.

Itea

. . 65

61,62

$\begin{aligned} & \text { Jacaranda } \\ & \text { asminums }\end{aligned} \ldots . .50,68$

Jerusalemthorn …58

Juniperus

$\mathbf{K}_{\text {ennedya }}^{\text {afir Lily......... }}$

Kniphofia …....66

Kolkwitzia ........71
Korean Cherry...72,82

Koreanspice …....72

agerstroemia . . . 66

Lantanas ........51

Lavender

Lavandula .........50

Lemon Verbena ....51

Leptospermum .....5 51

Libocedrus ........64

Ligustrums .......5I

Lilacs .........42, 72

Lily-of-the-Valley

$$
\text { Tree }
$$

Lippia

Liquidambar …6.69 69

Liriodendron .....66

Lonicera …......6. 62

$\mathbf{M}^{\text {agnolias .....58, 71 }}$

Marguerites

Matilija Poppy

Melia .

Mexican Mallow

Mexican Orange

Mint

llock Orange...

Moraeas

Morus

Vulberries

Murraya

Musa

Myoporum

Myrtle

Myrtus

$\mathbf{N}$ andina

Neillia.....

Nerium

Night Blooming

Jessamine …...43

O aks .............58 


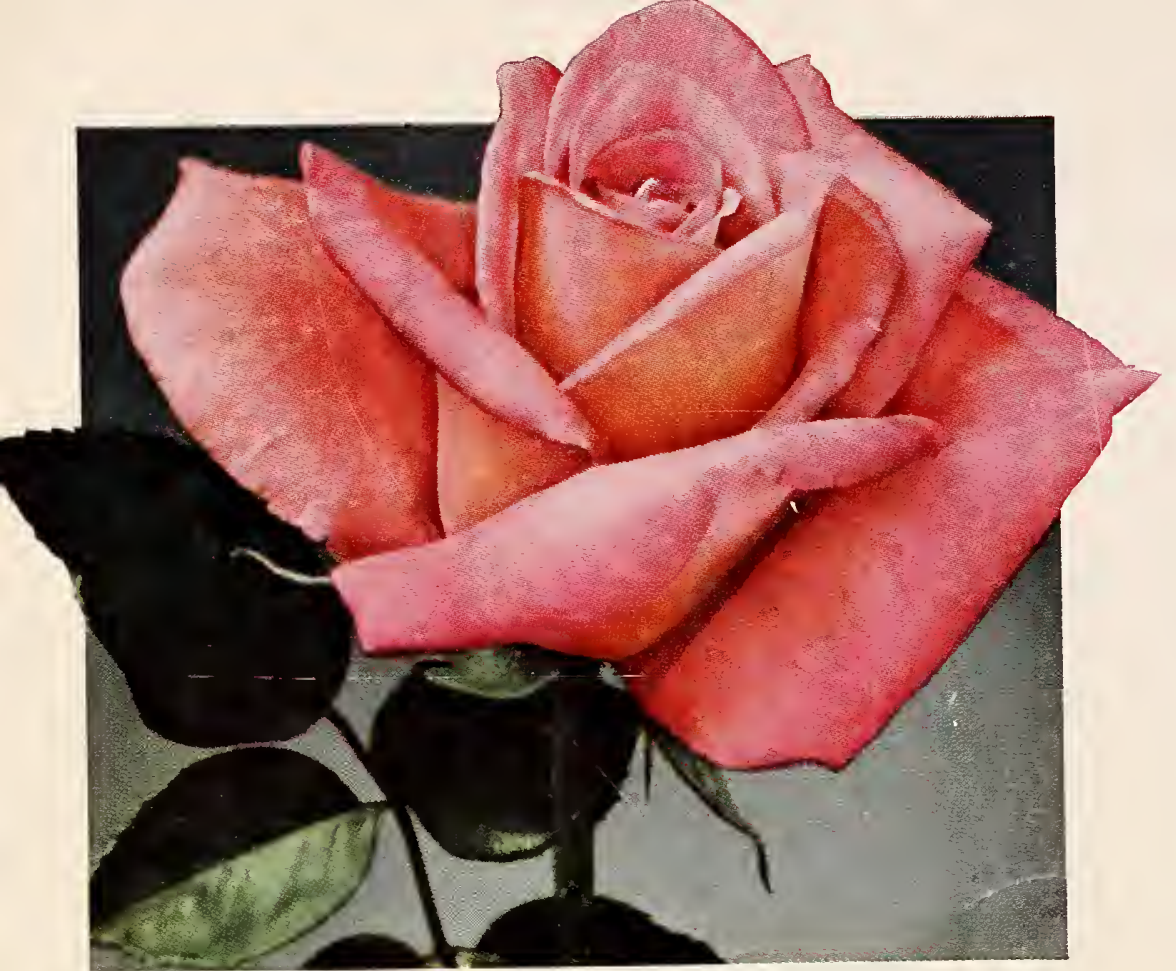

\section{New for 1952}

\section{The Latest Products of Armstrong Research}

For over 17 years we have worked toward developing more beautiful new roses than the world has yet seen. Another aim is fruit trees which will produce not only fruit of the highest quality, but do it consistently in the warmer wintered locations where standard kinds fail. Helen Traubel, the All-America Winner for 1952, is our latest rose creation, and Panamint, an outstanding new yellow-fleshed nectarine is brand new for 1952. Scientific plant breeding to produce better varieties for Armstrong customers will continue unabated, and we can promise you many fine things in the future.

\section{Rose}

\section{Helen Traubel}

Fittingly named for one of America's most beloved vocalists. This great new All-America Winner for 1952 shades from warm pink to luminous apricot, and beth the large long buds and glorious fragrant blooms are magnificent. It's a vigorous plant with abundant foliage and will become one of the largest in your garden. See page 6. Plant Pat. No. 1028.

$\$ 2.75$ each; 3 or more, $\$ 2.40$ eoch.

\section{Nectarine}

\section{Panamint}

A most welcome addition to the new nectarine varieties developed by Armstrong hybridists (all of them are described on page 78 ). Panamint features early ripening, large size, rich coloring, and a delicious flavor. But most important, you can depend upon a large crop of fruit each year in areas where winters are mild. Plant Pat. Appl. for. $\$ 2.75$ eoch, 10 for $\$ 24.00$.
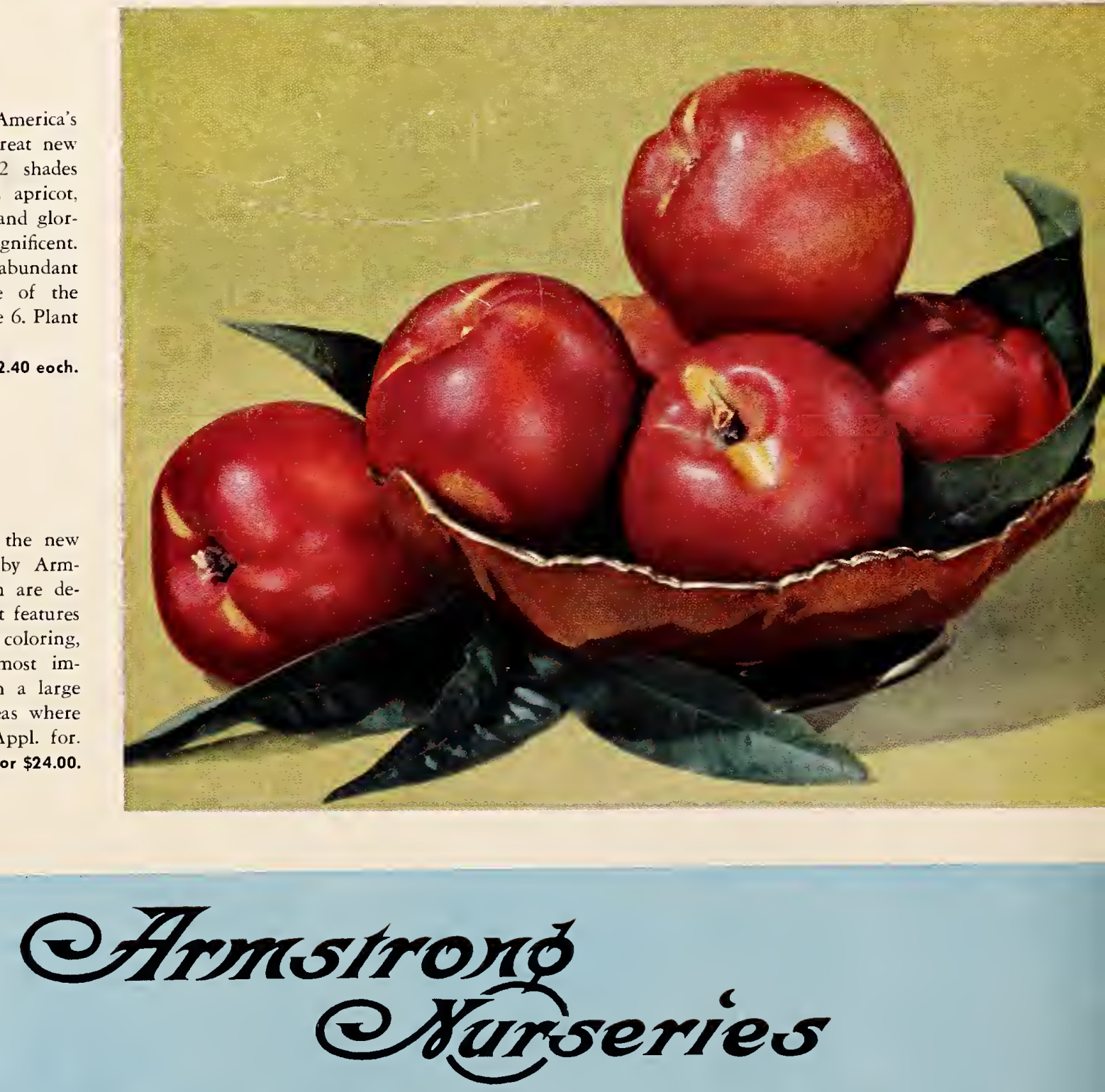

408 North Euclid Ave.

\section{ONTARIO, CALIFORNIA}

Culver City

4440 Sepulvedo Blvd.

Phone: VErmont 82-665
Long Beach

3759 Long Beach Blvd.

Phone: Long Beoch 45-118
Phone: Ontario 627-61

12908 Mognolio Blvd.

Phones: SUnset 11522

STanley 72394
San Marino

2920 Huntington Dr. Phone: ATlontic 95041 